Andrews University

Digital Commons @ Andrews University

2010

\title{
A Historical-Contextual Analysis of the Final-Generation Theology of M. L. Andreasen
}

Paul M. Evans

Andrews University, evanspm@andrews.edu

Follow this and additional works at: https://digitalcommons.andrews.edu/dissertations

Part of the Religious Thought, Theology and Philosophy of Religion Commons

\section{Recommended Citation}

Evans, Paul M., "A Historical-Contextual Analysis of the Final-Generation Theology of M. L. Andreasen" (2010). Dissertations. 1725.

https://digitalcommons.andrews.edu/dissertations/1725

https://dx.doi.org/10.32597/dissertations/1725

This Dissertation is brought to you for free and open access by the Graduate Research at Digital Commons @ Andrews University. It has been accepted for inclusion in Dissertations by an authorized administrator of Digital Commons@ Andrews University. For more information, please contact repository@andrews.edu. 


\begin{abstract}
A HISTORICAL-CONTEXTUAL ANALYSIS OF THE FINAL-GENERATION THEOLOGY OF M. L. ANDREASEN
\end{abstract}

by

Paul M. Evans

Adviser: Jerry A. Moon 


\title{
ABSTRACT OF GRADUATE STUDENT RESEARCH
}

Dissertation

\author{
Andrews University
}

Seventh-day Adventist Theological Seminary

\section{Title: A HISTORICAL-CONTEXTUAL ANALYSIS OF THE FINAL-GENERATION THEOLOGY OF M. L. ANDREASEN}

Name of researcher: Paul M. Evans

Name and degree of faculty adviser: Jerry A. Moon, Ph.D.

Date completed: July 2010

\section{Topic}

This study analyzes the teaching of the early twentieth-century Seventh-day Adventist writer M. L. Andreasen regarding a final-generation perfection that vindicates God in the great controversy between good and evil, comparing Andreasen's views with related concepts in the writings of previous Adventist writers.

\section{Purpose}

The study has the limited objective of attempting to trace possible antecedents for Andreasen's final-generation theology in the writings of other Adventists, in order to determine the degree of uniqueness or variance in Andreasen's views. By means of this historical-contextual analysis, relationships are clarified between Andreasen's views and 
those of other prominent Adventist writers, such as Joseph Bates, Ellen White, J. N. Andrews, Uriah Smith, E. J. Waggoner, and A. T. Jones.

Since non-Andreasen Adventist writings subsequent to Andreasen's 1937 The Sanctuary Service are not examined, later reaction to Andreasen's last-generation concepts is not addressed by this study. Further, an examination of the validity, or biblical foundation, of final-generation theology lies outside the scope of this work.

\section{Sources}

Andreasen's published books and articles were examined for his final-generation views, which are stated most fully in the penultimate chapter of his 1937 The Sanctuary Service, entitled "The Last Generation." The principal secondary source used was Dwight Eric Haynes's M.A. thesis on Andreasen's final-generation theology; Haynes's categorization of Andreasenian motifs was adapted for the purposes of this study.

The views of other, pre-1937 Adventist writers were researched primarily with the aid of digitized libraries; the two primary collections used were (1) the second edition of the Adventist Pioneer Library's Words of the Pioneers and (2) version 3.0 of the Ellen G. White Estate's The Complete Published Ellen G. White Writings. The Online Document Archives of the Office of Archives and Statistics of the General Conference of Seventhday Adventists also made possible the location of a few key documents not found in the other collections.

\section{Conclusions}

This study found all of the basic components of Andreasen's final-generation theology expressed by previous Adventist writers. In regard to complete overcoming of 
sin on the part of believers anticipating translation, a rather consistent correspondence was observed over the period investigated. Less agreement was seen regarding the relationship between an end-time blotting out of sins and an end-time maturation of the saints, with A. T. Jones and Andreasen seeing a clear connection, while Ellen White, significantly, refrained from explicitly joining these two end-time phenomena.

With attention was turned to the relationship between the end-time overcoming of the saints and the vindication of God in His controversy with evil, much less correspondence was observed. While antecedents for this part of Andreasen's theology seem implied in several passages from Ellen White, they become quite explicit in the writings of E. J. Waggoner. In the post-1888 years, Waggoner's view of an end-time vindication of God based on the overcoming of His people, seems to have been spreading, as witnessed in the writings of W. W. Prescott, I. H. Evans, and Uriah Smith. The study concludes that while Andreasen did not invent the concepts on which his final-generation theology is based, he did craft them into an end-time scenario by which he links the end-time saints to the outcome of the cosmic controversy much more emphatically than does any previous Adventist writer. 
Andrews University

Seventh-day Adventist Theological Seminary

\title{
A HISTORICAL-CONTEXTUAL ANALYSIS OF THE FINAL-GENERATION THEOLOGY \\ OF M. L. ANDREASEN
}

\author{
A Dissertation \\ Presented in Partial Fulfillment \\ of the Requirements for the Degree \\ Doctor of Philosophy
}

by

Paul M. Evans

July 2010 
(C) Copyright by Paul M. Evans 2010

All Rights Reserved 


\title{
A HISTORICAL-CONTEXTUAL ANALYSIS OF THE FINAL-GENERATION THEOLOGY \\ OF M. L. ANDREASEN
}

\author{
A dissertation \\ presented in partial fulfillment \\ of the requirements for the degree \\ Doctor of Philosophy
}

by

Paul M. Evans

APPROVAL BY THE COMMITTEE:

Faculty Adviser,

Jerry A. Moon

Associate Professor of Church History

Denis Fortin

Professor of Theology

John K. McVay

Professor of New Testament Studies

Walla Walla University

Darius W. Jankiewicz

Associate Professor of Theology

Roy Adams

Associate Editor

Adventist Review/Adventist World
Director, Ph.D. in Religion/Th.D. Program

Rudi Maier

Dean, SDA Theological Seminary

Denis Fortin 
To Sung Oc, Michelle, and Erica 


\section{TABLE OF CONTENTS}

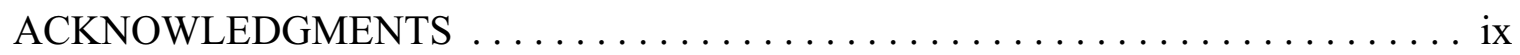

\section{Chapter}

1. INTRODUCTION $\ldots \ldots \ldots \ldots \ldots \ldots \ldots \ldots \ldots \ldots \ldots \ldots \ldots \ldots \ldots \ldots \ldots$

Background of the Problem $\ldots \ldots \ldots \ldots \ldots \ldots \ldots \ldots \ldots \ldots$

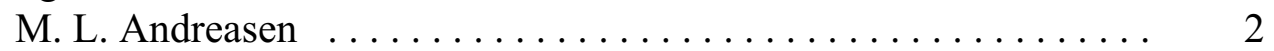

Studies on Andreasen $\ldots \ldots \ldots \ldots \ldots \ldots \ldots \ldots \ldots \ldots \ldots$

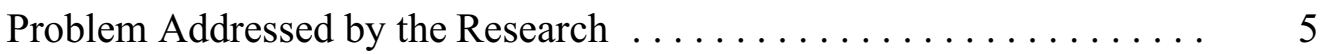

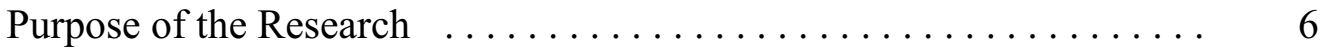

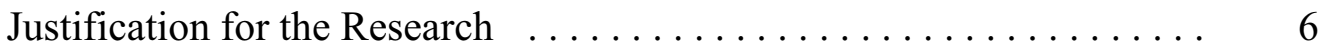

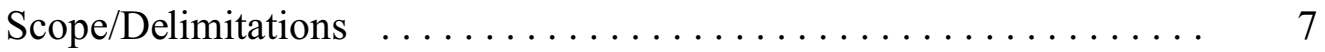

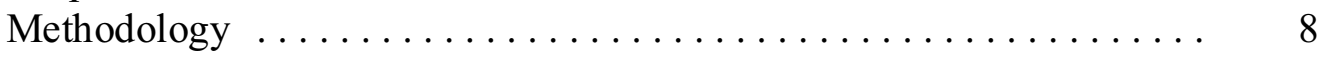

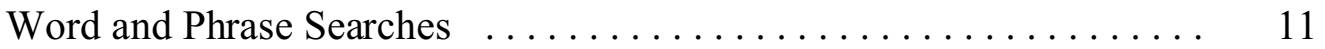

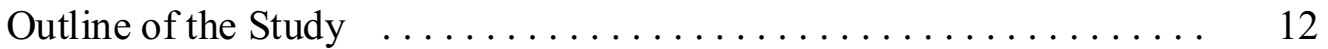

2. FOUNDATIONS FOR A FINAL-GENERATION THEOLOGY,

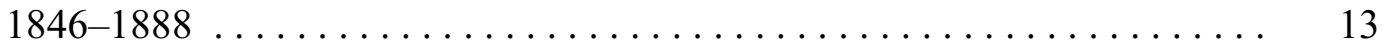

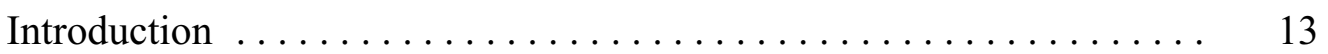

Crosier's Understanding of the Day of Atonement Antitype . . . . . . . . . 14

Early Publishing Activities ..................... 14

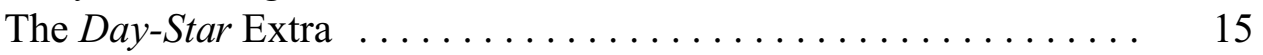

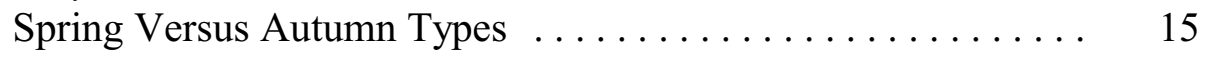

Significance of the Day of Atonement . . . . . . . . . . . 17

Cleansing of the sanctuary $\ldots \ldots \ldots \ldots \ldots \ldots \ldots \ldots$

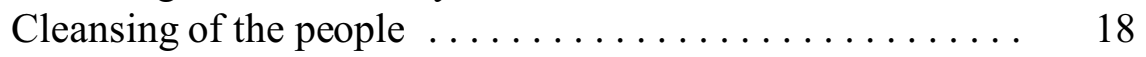

Joseph Bates's View of the Cleansing of the Sanctuary . . . . . . . . 20

The Voice of God and a Cleansed People ............... 21

Complete Sanctification in Connection with the Sabbath . . . . . . . 22

The Sealing Process and the Cleansing of the Sanctuary ........ 24

Trial Before Sins Blotted Out ............... 24

Perfecting of the Saints as a Preparation ............. 25

Ellen White's Views of End-Time Events . . . . . . . . . . . . . 29

Focus on the 144,000 in Her First Visions, 1844-1845 . . . . . . 30 
Early Sketches of Needed Preparation

for the Time of Trouble, $1845-1849 \ldots \ldots \ldots \ldots \ldots \ldots . \ldots 32$

Blotting Out of Sins before Christ Leaves the Sanctuary ..... 33

Satan's Efforts to Deceive .................... 35

Focus on Preparing for the Time of Trouble, $1850-1857 \ldots \ldots \ldots .37$

Purified by Obedience to the Truth . . . . . . . . . . . . . . . 39

Reflecting the Image of Jesus $\ldots \ldots \ldots \ldots \ldots \ldots \ldots .40$

Complete Victory over Sin $\ldots \ldots \ldots \ldots \ldots \ldots \ldots \ldots . \ldots \ldots$

Confession of Sin and a Deep Experience .............. 42

Sealing Places beyond Satan's Power . . . . . . . . . . . 43

Satan's Efforts to Prevent Sealing . . . . . . . . . . . . . 44

The Great Controversy Vision, $1858 \ldots \ldots \ldots \ldots \ldots \ldots \ldots . \quad 45$

Preparing for Translation, $1859-1868 \ldots \ldots \ldots \ldots \ldots \ldots \ldots . \ldots \ldots$

Without Blemish ........................... 49

A Goal-Driven Process $\ldots \ldots \ldots \ldots \ldots \ldots \ldots \ldots \ldots \ldots \ldots \ldots$

Continuing Sense of Unworthiness $\ldots \ldots \ldots \ldots \ldots \ldots . \quad 56$

Delivered by the Voice of God ................. 58

Expanded Views of the Great Controversy, 1869-1883 ....... 58

Character Perfection a Universal Requirement .......... 59

Needed Preparation for Translation ................ 60

The Time and Extent of the Purifying Process $\ldots \ldots \ldots \ldots .62$

A Final Work of Vindication .................. 66

Developed Portrayal of the Time of Trouble (1884-1888) ...... 69

Spirit of Prophecy, Volume 4, $1884 \ldots \ldots \ldots \ldots \ldots \ldots \ldots .70$

Other Writings from the Period, $1884-1888 \ldots \ldots \ldots \ldots \ldots .76$

The Great Controversy, $1888 \ldots \ldots \ldots \ldots \ldots \ldots \ldots . \ldots \ldots$

Other Pioneer Adventist Authors on End-time Events $\ldots \ldots \ldots \ldots . \quad 88$

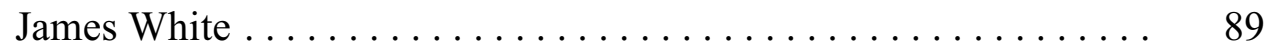

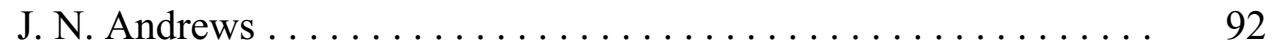

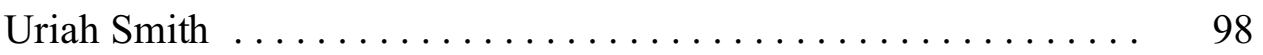

Other Authors ........................... 101

Hoping and Praying to Be Ready ................. 102

R. F. Cottrell ............................. 103

D. T. Bourdeau ............................ 105

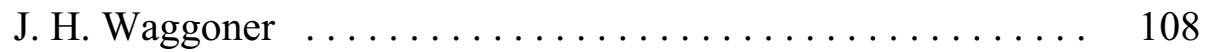

Summary and Conclusion $\ldots \ldots \ldots \ldots \ldots \ldots \ldots \ldots \ldots \ldots$

3. EMERGENCE OF FINAL-GENERATION CONCEPT, 1888-1915 $\ldots . .117$

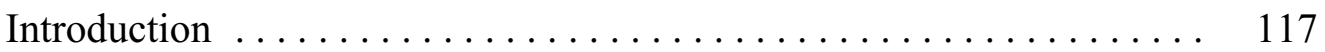

Ellen Whites Post-1888 Outlook on End-Time Events . . . . . . . . . 117

Preparation for the End ......................... 118

The Latter Rain $\ldots \ldots \ldots \ldots \ldots \ldots \ldots \ldots \ldots \ldots \ldots \ldots \ldots$

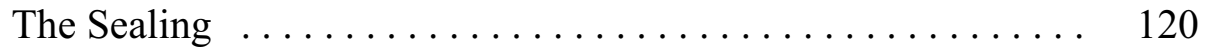

The Time of Trouble $\ldots \ldots \ldots \ldots \ldots \ldots \ldots \ldots \ldots \ldots$ 
Translation at Christ's Appearing . . . . . . . . . . . . 122

Perfection of the Church . . . . . . . . . . . . . . . . . . 124

The Robe of Righteousness . . . . . . . . . . . . . . . . 124

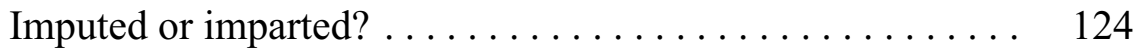

Joshua and the Angel . . . . . . . . . . . . . . . . . 128

Character Perfection and the End of Time . . . . . . . . . . . 133

Possible or impossible? ................... 133

No softening on the requirement $\ldots \ldots \ldots \ldots \ldots \ldots \ldots \ldots$

Doubts, denials, excuses . . . . . . . . . . . . 134

As Christ overcame ................... 137

Reflecting the divine image .............. 138

A process of polishing ................ 139

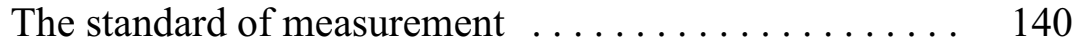

End-time Vindication of God . . . . . . . . . . . . . . . . . . . . . . . 144

Can the Law Be Obeyed $\ldots . \ldots \ldots \ldots \ldots \ldots \ldots \ldots \ldots \ldots$

Can Sinners Be Forgiven? . . . . . . . . . . . . . . . . . 147

A. T. Jones and the Cleansing of the Sanctuary . . . . . . . . . . . 150

Following Ellen White on Perfection $\ldots \ldots \ldots \ldots \ldots \ldots \ldots \ldots$

A Complete Cleansing from $\operatorname{Sin} \ldots \ldots \ldots \ldots \ldots \ldots \ldots . \ldots \ldots$

The Seal of Perfection ................... 153

Replicability of Christ's Victory . . . . . . . . . . . . . . . 153

Cleansing of the Sanctuary . . . . . . . . . . . . . . . 156

E. J. Waggoner Advances Eschatological Vindication . . . . . . . . . . 158

Independent of Humans . . . . . . . . . . . . . . . . . . . . . . . . . . . 159

Dependent on Humans . . . . . . . . . . . . . . . . . . . . . . . . 159

Purpose of the Judgment $\ldots \ldots \ldots \ldots \ldots \ldots \ldots \ldots \ldots \ldots$

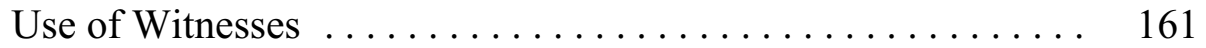

Witnesses Replicate Christ's Life . . . . . . . . . . . . . . . . . . . 163

God Manifest in Sinful Flesh . . . . . . . . . . . . . . . . . . . . . . . . 164

The "Holy Flesh" Movement and Final-Generation Theology . . . . . . 166

Cleansing in Preparation for Translation $\ldots \ldots \ldots \ldots \ldots$

God Manifest in Sinless Flesh . . . . . . . . . . . . . . . . . . 167

Last-Day Events in the Writings of Other Adventist Authors . . . . . . . 169

Standing without a Mediator $\ldots \ldots \ldots \ldots \ldots \ldots \ldots \ldots \ldots \ldots$

End-time Vindication of God . . . . . . . . . . . . . . . . . 174

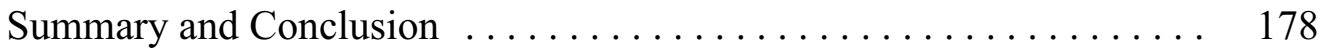

\section{A DEVELOPED FORMULATION OF THE FINAL GENERATION,} 1915-1937

Introduction $\ldots \ldots \ldots \ldots \ldots \ldots \ldots \ldots \ldots \ldots \ldots \ldots \ldots \ldots$

Andreasen's Contemporaries on Eschatology and the Sanctuary . . . . . 184

A. G. Daniells . . . . . . . . . . . . . . . . . . . . . . . 184

W. W. Prescott . . . . . . . . . . . . . . . . . . . . . . . . 186

Meade MacGuire .............................. 190 
The 1930s Focus on the Sanctuary . . . . . . . . . . . . . . . . 192

C. H. Watson . . . . . . . . . . . . . . . . . . . . . . 192

W. H. Branson . . . . . . . . . . . . . . . . . . . . . . . 195

Views on the Meaning of the Antitypical Day of Atonement . . . . 197

Significant Aspects of Andreasen's Biography . . . . . . . . . . . . 201

Andreasen's Views on the Final Generation . . . . . . . . . . . . . . . 206

Challenge and Vindication . . . . . . . . . . . . . . . 207

Satan's Challenge before the Cross . . . . . . . . . . . . 207

Christ Answers the Challenge ................. 210

Renewed Challenge after the Cross . . . . . . . . . . . . . 211

Job as a Type of the Final Generation . . . . . . . . . . . 214

Demonstration of the Gospel's Power . . . . . . . . . . 218

Vindication of God ................... 223

Salvation as Complete Victory over Sin . . . . . . . . . . . . 224

Purpose of the Sanctuary . . . . . . . . . . . . . . . 224

Views of Sin and Obedience ................. 228

Salvation as Complete Restoration $\ldots \ldots \ldots \ldots \ldots \ldots \ldots$

Summary and Conclusion $\ldots \ldots \ldots \ldots \ldots \ldots \ldots \ldots \ldots \ldots$

5. ANDREASEN'S VIEWS COMPARED WITH RELATED THEMES IN THE WRITINGS OF OTHER ADVENTIST WRITERS . . . . . . . . . . 238

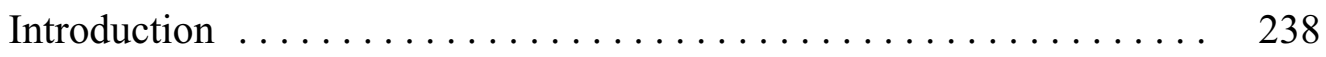

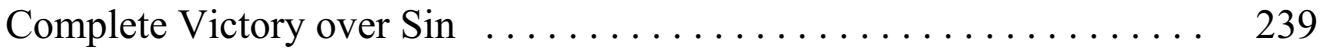

Compared with the Writings of Ellen White . . . . . . . . . . . 240

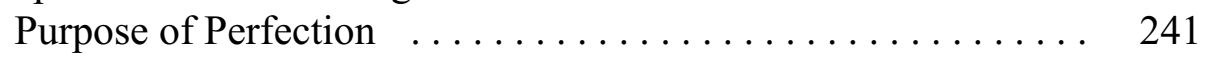

Extent of Overcoming ................... 243

Restoration of Aspects of the Pre-Fall Human Condition ... . 244

The Role of Christ in Showing the Way . . . . . . . . . . 248

Views of Sin and Righteousness ................ 249

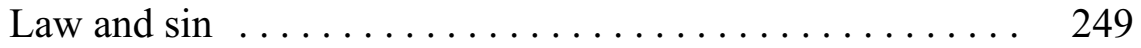

Interpretation of the sanctuary service $\ldots \ldots \ldots \ldots \ldots 251$

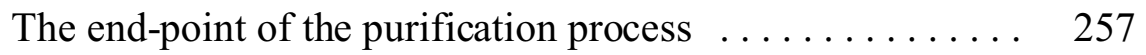

Summary ........................ 258

Compared with Contemporaneous and Earlier Adventist Writers . . 259

An Eschatological Overcoming of Sin ... . . . . . . . 260

The Meaning of Sins Blotted Out .............. 265

Restoration of Aspects of the Pre-Fall Human Condition . . . 268

The Role of Christ in Showing the Way . . . . . . . . . . . 270

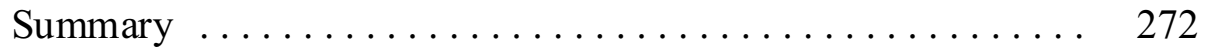

Challenge and Vindication $\ldots \ldots \ldots \ldots \ldots \ldots \ldots \ldots \ldots \ldots \ldots \ldots$

Compared with the Writings of Ellen White . . . . . . . . . 275

God's Rule Challenged ..................... 275

Christ as the Answer ... . . . . . . . . . . . . . . . . . 277

Renewed Challenge after the Cross . . . . . . . . . . 279 
Dependence on Witnesses ................... 281

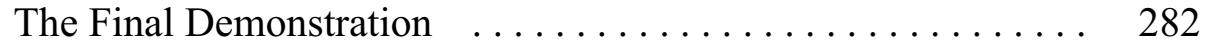

Vindication of God ................... 286

Compared with Contemporaneous and Earlier Adventist Writers . . 290

Christ as Vindicator of the Law . . . . . . . . . . . . . 291

Post-Calvary Vindication . . . . . . . . . . . . . . . . . . . 294

God's Dependence on Witnesses ................. 296

The Final Demonstration Vindicates God . . . . . . . . . . . 299

Summary and Conclusion . . . . . . . . . . . . . . . . . . . . . . 301

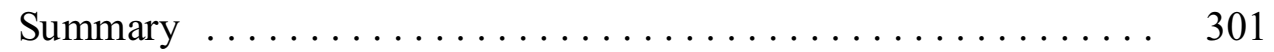

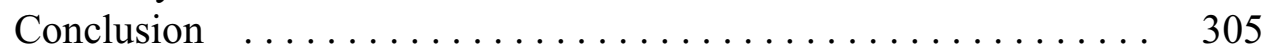

6. SUMMARY AND CONCLUSIONS $\ldots \ldots \ldots \ldots \ldots \ldots \ldots \ldots \ldots$

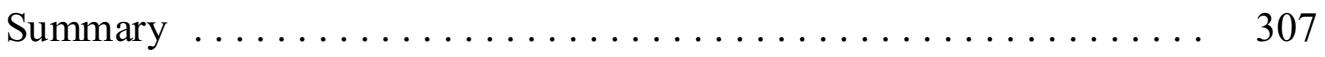

Conclusions ................................ 319

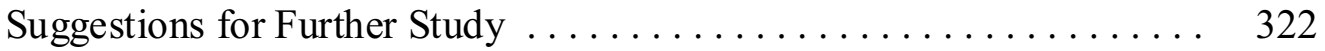

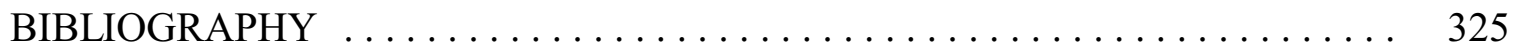




\section{ACKNOWLEDGMENTS}

Besides the usual sense of indebtedness a researcher feels to those who have been helpful in guiding and assisting in the endeavor (and I could mention my adviser and the rest of the dissertation committee, the staff at the Center for Adventist Research at Andrews University, as well as at the Office of Archives and Statistics at the General Conference of Seventh-day Adventists), I feel a special debt of gratitude to a corps of individuals who do not usually receive such words of thanks. As this study depends heavily on the enormous amount of data that has been made accessible and searchable through digitized media, I would like to express my sincere appreciation to those unnamed individuals who have spent hours of tedious labor to convert printed source material to electronic form. I have reaped the fruit of their labors. Without their attention to detail, entering and checking data for accuracy, these digital resources would not be available, and a study of this kind would be much more time-consuming, if possible at all. Accordingly, I would like to pay tribute to all those who had a part in the production of the digital resources made available by the Ellen G. White Estate, the Adventist Pioneer Library, and the Office of Archives and Statistics of the General Conference of Seventhday Adventists. M. L. Andreasen and previous generations of inquiring minds could not even dream of what is possible today through the combined efforts of these many unnamed and unsung heroes. 


\section{CHAPTER 1}

\section{INTRODUCTION}

\section{Background of the Problem}

During the last quarter of the twentieth century Seventh-day Adventist theology became increasingly polarized over questions of the nature of Christ, the attainability of character perfection, righteousness by faith, and the meaning of the sanctuary and the investigative judgment. ${ }^{1}$ Though many of these issues were intensely argued in reaction

${ }^{1}$ For examples and discussion of the debate, see Herbert E. Douglass, Edward Heppenstall, Hans K. LaRondelle, and C. Mervyn Maxwell, Perfection: The Impossible Possibility (Nashville: Southern, 1975); Geoffrey J. Paxton, The Shaking of Adventism (Grand Rapids, MI: Baker, 1978); A. Leroy Moore, Theology in Crisis: Or, Ellen G. White's Concept of Righteousness by Faith as It Relates to Contemporary SDA Issues (Corpus Christi, TX: Life Seminars, 1980); Eric Claude Webster, Crosscurrents in Adventist Christology (New York: P. Lang, 1984; reprint, Berrien Springs, MI: Andrews University Press, 1992); George R. Knight, Angry Saints: Tensions and Possibilities in the Adventist Struggle over Righteousness by Faith (Hagerstown, MD: Review and Herald, 1989); Roy Adams, The Nature of Christ: Help for a Church Divided over Perfection (Hagerstown, MD: Review and Herald, 1994); Martin Weber, Who's Got the Truth? Making Sense out of Five Different Adventist Gospels (Silver Spring, MD: Home Study International Press, 1994); A. Leroy Moore, Adventism in Conflict (Hagerstown, MD: Review and Herald, 1995); J. R. Zurcher, Touched with Our Feelings: A Historical Survey of Adventist Thought on the Human Nature of Christ (Hagerstown, MD: Review and Herald, 1999); George R. Knight, A Search for Identity: The Development of Seventh-day Adventist Beliefs (Hagerstown, MD: Review and Herald, 2000). An interesting recent investigation of theodicy in the OT sanctuary ritual is Roy Gane, Cult and Character: Purification Offerings, Day of Atonement, and Theodicy (Winona Lake, IN: Eisenbrauns, 2005). 
to the views expressed by Desmond Ford toward the end of the 1970s, Adventist historian George Knight has pointed out the "crucial role" of the theology of M. L. Andreasen in the battles that raged during the latter part of the twentieth century. ${ }^{2}$

\section{L. Andreasen}

Milian Lauritz Andreasen (1876-1962) was an influential Seventh-day Adventist educator/theologian of the early twentieth century. He taught at the Seventh-day Adventist Theological Seminary for over ten years toward the end of his career, and wrote many books and articles for the denomination. ${ }^{3}$ Four of his books were selected for inclusion in the Christian Home Library series. ${ }^{4}$ Among his most influential works was The Sanctuary Service, published in 1937, with a revised edition issued in 1947. His chapter, "The Final Generation," develops the idea that the people of God living on earth just before Christ comes again will perfectly overcome sin and thus finally vindicate God in the great controversy. ${ }^{5}$

\section{Studies on Andreasen}

In spite of Andreasen's key role in the struggles of the twentieth century,

${ }^{2}$ Knight, Search for Identity, 144-152, 164-178.

${ }^{3}$ Seventh-day Adventist Encyclopedia, 2d rev. ed. (1996), s.v. “Andreasen, Milian Lauritz."

${ }^{4}$ M. L. Andreasen, A Faith to Live By (Washington, DC: Review and Herald, 1943); idem, The Book of Hebrews (Washington, DC: Review and Herald, 1948); idem, The Faith of Jesus (Washington, DC: Review and Herald, 1949); idem, Prayer (Mountain View, CA: Pacific Press, 1957).

${ }^{5}$ M. L. Andreasen, The Sanctuary Service, 2d ed., rev. (Washington, DC: Review and Herald, 1947), 299-321. 
relatively few studies have attempted to systematically analyze his theology. To date, one biography has been published. ${ }^{6}$ Andreasen's concept of the final generation and the challenge it faces are considered by his biographer to be his greatest contribution. ${ }^{7}$ However, most of the biography is devoted to Andreasen's contributions in the area of education, and no description of his theology is given.

A number of papers have treated Andreasen's theology. Shorter papers by Arthur J. Stagg and Darius W. Jankiewicz dealt respectively with the doctrines of atonement and sin in Andreasen's writings, while part of a recent thesis by Jamie Kiley dealt with Andreasen's views on the atonement, the nature of sin, and the nature of Christ. ${ }^{8}$ Roy Adams's dissertation compared the sanctuary views of Andreasen, Uriah Smith, and Albion Ballenger.' Andreasen's role in the controversy surrounding the issuing of

${ }^{6}$ Virginia Steinweg, Without Fear or Favor: The Life of M. L. Andreasen (Washington, DC: Review and Herald, 1979). Two short biographical papers are also accessible: Kenneth Perman, “A Biographical Sketch of M. L. Andreasen” (term paper, Andrews University, 1974), Center for Adventist Research, James White Library, Andrews University, Berrien Springs, MI (hereinafter CAR); Wesley Hallman, “A Biography of Milian Lauritz Andreasen During the Years 1935-1950" (term paper, Andrews University, 1974), CAR.

${ }^{7}$ Steinweg, Without Fear or Favor, 10.

${ }^{8}$ Arthur J. Stagg, "The Doctrine of Atonement as Presented by M. L. Andreasen" (term paper, Andrews University, 1995), CAR; Darius W. Jankiewicz, "The Doctrine of Sin within Its Soteriological Context in the Writings of M. L. Andreasen" (term paper, Andrews University, 1996), CAR; Jamie Kiley, "The Doctrine of Sin in the Thought of George R. Knight: Its Context and Implications" (M.A. thesis, Andrews University, 2009).

${ }^{9}$ Roy Adams, The Sanctuary Doctrine: Three Approaches in the Seventh-day Adventist Church (Berrien Springs, MI: Andrews University Press, 1981). See also Roy Adams, The Sanctuary: Understanding the Heart of Adventist Theology (Hagerstown, MD: Review and Herald, 1993). 
Questions on Doctrine was studied by Jerry Moon. ${ }^{10}$ Two recent dissertations, by Paul McGraw and Juhyeok Nam, focus on this attempt by Adventists to find acceptance in the larger Christian community, with the accompanying sharp negative reaction from Andreasen on the Adventist side. ${ }^{11}$ A. Leroy Moore, who in his earlier works had touched on the Andreasen - Questions on Doctrine conflict, has recently analyzed this debate in Questions on Doctrine Revisited! He concludes by critiquing and revising Andreasen's final-generation motif. ${ }^{12}$

Andreasen's final-generation theology was the focus of Dwight Eric Haynes's M.A. thesis. ${ }^{13}$ Haynes attempted to sketch a developing line of thought in Andreasen's writings, but instead found the concept of the last generation fairly well established from Andreasen's first published articles. He categorized Andreasen's concept of the final generation under a number of motifs, such as challenge and vindication. While Haynes

\footnotetext{
${ }^{10}$ Jerry Allen Moon, "M. L. Andreasen, L. E. Froom, and the Controversy over Questions on Doctrine" (term paper, Andrews University, 1988), CAR. See Seventh-day Adventists Answer Questions on Doctrine, with notes and historical and theological introduction by George R. Knight, annotated ed. (Berrien Springs, MI: Andrews University Press, 2003).

${ }^{11}$ Paul McGraw, "Born in Zion? The Margins of Fundamentalism and the Definition of Seventh-day Adventism" (Ph.D. dissertation, The George Washington University, 2004); Juhyeok Nam, "Reactions to the Seventh-day Adventist Evangelical Conferences and Questions on Doctrine, 1955-1971" (Ph.D. dissertation, Andrews University, 2005).

${ }^{12} \mathrm{~A}$. Leroy Moore, Questions on Doctrine Revisited!: Keys to the Doctrine of Atonement and Experience of At-one-ment (Ithaca, MI: AB Publishing, 2005); idem, Theology Crisis; idem, Adventism in Conflict.

${ }^{13}$ Dwight Eric Haynes, "The Final Generation: A Descriptive Account of the Development of a Significant Aspect of M. L. Andreasen's Eschatology as Related to His Treatment of the Sanctuary Doctrine between 1924-1937" (M.A. thesis, Andrews University, 1990).
} 
traced the theology of Andreasen to its Arminian roots, he did not attempt to uncover the background of a final-generation motif within Adventism.

George Knight's survey of the development of Adventist doctrines includes a section analyzing Andreasen's final-generation theology, suggesting a number of concepts within Adventism on which Andreasen built his theology. ${ }^{14}$ These include early understandings of an ongoing atonement and a cleansing of believers on earth in parallel to the cleansing of the heavenly sanctuary. Later teachings of A. T. Jones and E. J. Waggoner are also pointed out by Knight as underlying Andreasen's theology, such as the post-Fall human nature of Christ and the end-time demonstration of complete obedience to God's commandments. Andreasen's dependence on key Ellen White statements is also noted.

\section{Problem Addressed by the Research}

There is a great deal of disagreement among Seventh-day Adventists as to the validity of M. L. Andreasen's final-generation theology. It is assumed by some that these views are a natural extension of concepts expressed in the writings of Ellen G White. Others see contradictions between Andreasen and White, and look to other Adventist writers for the origin of Andreasen's views. A thorough study of Andreasen's views that analyzes their origins, and their relationship to the views of Ellen White and other Adventist writers, has been lacking.

\footnotetext{
${ }^{14}$ Knight, Search for Identity, 144-152.
} 


\section{Purpose of the Research}

The purpose of this study is to analyze the final-generation theology of M. L. Andreasen within its historical context, looking for related theological antecedents within Adventism. A principal objective is to clarify the relationship between Andreasen's concepts and similar themes in the writings of Ellen White and other Adventists who wrote before 1937, the year of the publication of Andreasen's The Sanctuary Service.

\section{Justification for the Research}

This study is important because the final-generation theology of M. L. Andreasen is seen to have had a considerable impact on the shape of Adventist theology. Sabbatarian Adventist identity arose early from a unique understanding of the role of an antitypical heavenly sanctuary in last-day events. The cleansing of this sanctuary in a final pre-Advent judgment has been seen to involve a corresponding cleansing of believers on earth. What this cleansing involves has been the subject of much debate. ${ }^{15}$ Some who accept Andreasen's views envision a complete sanctification in which sin is totally overcome in the lives of believers in the final generation. Those holding this view consider Andreasen's theology as the epitome of Adventist distinctiveness. Others see Andreasen's final-generation theology as a departure from Adventist, as well as Christian, teaching. ${ }^{16}$

${ }^{15}$ For an example, see Donald K. Short, "Then Shall the Sanctuary Be Cleansed" (Paris, OH: Glad Tidings, 1991). See also Knight's criticism of Short's finaldemonstration concept (Knight, Search for Identity, 181).

${ }^{16}$ Two examples, showing differing treatments of final-generation theology, are: Clifford R. Goldstein, "The Full and Final Display," Ministry, October 1994, 41-43, 62; Woodrow W. Whidden, "The Vindication of God and the Harvest Principle," Ministry, 
The disagreement is not only over the nature and results of Andreasen's ideas, but also as to their source. Although this study is not intended to evaluate the truth of Andreasen's assertions, a comparison of Andreasen's final-generation concepts with those of Ellen White and other prior Adventist writers can help clarify the commonalities and variances between them. As this study delineates historical antecedents of the views articulated by Andreasen, it may help to bring more light to discussions. A more complete understanding of the background of Andreasen's thought may even increase the possibilities for more fruitful dialogue within the Adventist theological community.

\section{Scope/Delimitations}

This study concerns itself with the period from the October 22, 1844, disappointment through 1937, in connection with a search for possible antecedents to Andreasen's theology. By 1937, Andreasen's final-generation theology was fully set forth in The Sanctuary Service. Later works by Andreasen, though, were also examined for additional evidence of his views. The impact of these concepts of Andreasen on subsequent Adventist thinkers, though a needed study, was not addressed.

In the analysis of Andreasen's views, the focus was on aspects of vindication and complete sanctification in connection with the last generation. Though the human nature of Christ turned out to be a crucial component of Andreasen's theology, this was not

October 1994, 44-47. A recent exposition of final-generation theology is Herbert E. Douglass, God at Risk: The Cost of Freedom in the Great Controversy between God and Satan (Roseville, CA: Amazing Facts, 2004). An earlier study that argues for the final generation's participation in the vindication of God is Robert J. Wieland, "The Atonement in Its Wider Aspect as a Vindication before the Universe of the Character of God" (term paper, Andrews University, 1965), CAR. 
recognized when Andreasen developed his final-generation concepts. As the question of the nature of Christ has been addressed quite fully elsewhere, it was not analyzed in depth in this study. ${ }^{17}$

A rather important delimitation of this study is its intended restriction to questions of historical antecedents within the Adventist faith community, avoiding higher questions regarding the validity of Andreasen's ideas, or their harmony with biblical materials and the views of theologians in general. Thus most of the research effort was spent in looking for related views held by other Adventist authors, the purpose of this study not being to evaluate the truth, or biblical foundation, of Andreasen's views.

\section{Methodology}

The aim of this study was to ascertain the degree to which M. L. Andreasen's final-generation views differ from those of other Adventist writers of his time and before. Thus a comparison was made of the works of Andreasen and other Adventist authors which deal especially with events seen as occurring after an end-time close of probation. In surveying key writings of Adventists, attention was given to any indications of a developing consciousness of what later came to be seen as Andreasen's final-generation motif. The study begins with a historical survey of Adventist thought related to Andreasen's final-generation concepts. After the survey is brought up to the time of Andreasen's 1937 The Sanctuary Service, a detailed description of the basic components of Andreasen's views is presented. These components of Andreasen's final-generation

\footnotetext{
${ }^{17}$ See Webster, Crosscurrents in Adventist Christology; Adams, Nature of Christ; Woodrow W. Whidden, Ellen White on the Humanity of Christ: A Chronological Study (Hagerstown, MD: Review and Herald, 1997); Zurcher, Touched with Our Feelings.
} 
theology are then analyzed by directing attention to similar and dissimilar ideas expressed by other Adventist writers, in order to understand the nature of the relationships between the various views.

Among the main writings investigated in this search for the origins of Andreasen's final-generation theology are those by A. T. Jones, E. J. Waggoner, Ellen White, and Joseph Bates. Bates was the first to expound the idea that a group of people on earth would be perfected while the sanctuary in heaven was being cleansed. ${ }^{18}$ Waggoner's Everlasting Covenant, Jones's The Consecrated Way to Christian Perfection, and Bates's Second Advent Way Marks and High Heaps, Vindication of the Seventh-day Sabbath, and Seal of the Living God were among the first works studied for evidences of ideas similar to Andreasen's. ${ }^{19}$ Searches of relevant words and phrases in other Adventist writers were performed using the Words of the Pioneers CD-ROM, an

\footnotetext{
${ }^{18}$ See Knight, Search for Identity, 66-71.
}

${ }^{19}$ Ellet Joseph Waggoner, The Everlasting Covenant ([London]: International Tract Society, 1900); idem, The Everlasting Covenant: God's Promises to Us (Berrien Springs, MI: Glad Tidings, 2002); Alonzo Trevier Jones, The Consecrated Way to Christian Perfection (Mountain View, CA: Pacific Press, 1905); Joseph Bates, Second Advent Way Marks and High Heaps: Or a Connected View of the Fulfilment of Prophecy, by God's Peculiar People, from the Year 1840-1847 (New Bedford, MA: Press of Benjamin Lindsey, 1847; reprint, as pp. 41-122 of Bates' Pamphlets, Payson, AZ: Leaves-of-Autumn Books, 1987); idem, A Vindication of the Seventh-day Sabbath and the Commandments of God: With a Further History of God's Peculiar People from 18471848 (New Bedford, MA: Press of Benjamin Lindsey, 1848; reprint, as pp. 117-234 of The Sabbath Controversy, Payson, AZ: Leaves-of-Autumn Books, 1987); idem, A Seal of the Living God: A Hundred Forty-Four Thousand, of the Servants of God Being Sealed, in 1849 (New Bedford, MA: Press of Benjamin Lindsey, 1849; reprint, as pp. 1-72 of Joseph Bates et al., Early S.D.A. Pamphlets, Payson, AZ: Leaves-of-Autumn Books, 1987). 
electronic collection of mostly nineteenth-century Adventist writings. ${ }^{20}$ Robert

Haddock's collection of Adventist articles on the sanctuary was also consulted. ${ }^{21}$ Another useful source for uncovering early Adventist writings on the sanctuary is the fifth volume of the Daniel and Revelation Committee series of the Adventist-owned Biblical Research Committee, Doctrine of the Sanctuary: A Historical Survey (1845-1863). ${ }^{22}$

The writings of Ellen White were searched, especially The Great Controversy, Patriarchs and Prophets, The Desire of Ages, Early Writings, and the fourth volume of The Spirit of Prophecy. ${ }^{23}$ Relevant words and phrases were also located within the large corpus of White's published works with the aid of The Complete Published Ellen G. White Writings on CD. ${ }^{24}$ The limitations of word searches necessitated an additional

${ }^{20}$ Words of the Pioneers, $2 \mathrm{~d}$ ed. [CD-ROM] (Loma Linda, CA: Adventist Pioneer Library, 1995).

${ }^{21}$ Robert Haddock, "A History of the Doctrine of the Sanctuary in the Advent Movement, 1800-1905” (B.D. thesis, Andrews University, 1970).

${ }^{22}$ Frank B. Holbrook, ed., Doctrine of the Sanctuary: A Historical Survey (18451863) (Silver Spring, MD: Biblical Research Institute, General Conference of Seventhday Adventists, 1989).

${ }^{23}$ Ellen G. White, The Great Controversy between Christ and Satan: The Conflict of the Ages in the Christian Dispensation (Mountain View, CA: Pacific Press, 1950); idem, The Story of Patriarchs and Prophets: As Illustrated in the Lives of Holy Men of Old (Mountain View, CA: Pacific Press, 1958); idem, The Desire of Ages: The Conflict of the Ages Illustrated in the Life of Christ (Mountain View, CA: Pacific Press, 1940); idem, Early Writings of Ellen G. White (Washington, DC: Review and Herald, 1945); idem, The Spirit of Prophecy, 4 vols. (Battle Creek, MI: Steam Press, 1870-1884; reprint, Washington, DC: Review and Herald, 1969).

${ }^{24}$ Ellen G. White, The Complete Published Ellen G. White Writings, Version 3.0 [CD-ROM] (Silver Spring, MD: Ellen G. White Estate, 1997). A newer version, including a collection of Adventist writings that constituted an expansion of the 1995 Words of the Pioneers CD, was released in 2009 as Ellen G. White, Ellen G. White Writings: Comprehensive Research Edition 2008 [CD-ROM] (Silver Spring, MD: Ellen G. White Estate, 2009). 
examination and comparison of key passages dealing with end-time events. Andreasen's own views were obtained entirely from his published works, as the unpublished sources that were examined added no new information about his last-generation concepts. Special attention was given to relevant chapters in The Sanctuary Service, The Faith of Jesus, and The Book of Hebrews.

The facilities of the James White Library at Andrews University, which includes the rich resources of the Center for Adventist Research, were used for verification of data, as well as for perusing related published and unpublished works. The library holds numerous collections, some that include Andreasen's papers, as well as a large body of early Adventist publications. Andreasen's files in the possession of the General Conference Office of Archives and Statistics were examined, consisting partly of many note cards, on which are typed quotations from the writings of Ellen White. Others of these note card files, in the possession of Dr. John Baldwin, were also examined. The Online Document Archives of the Office of Archives and Statistics proved especially helpful in accessing and searching Adventist periodicals. ${ }^{25}$

\section{Word and Phrase Searches}

Relevant passages for this study were identified, using the advanced capabilities of digitized data, which greatly facilitates a comparative study of this nature, allowing the researcher to instantly locate words or phrases in a large body of literature. Among the words and phrases used (in various combinations and forms) in searches conducted of the digital resources were the following: accuse, at stake, blot, character, charge,

\footnotetext{
${ }^{25}$ Online Document Archives. http://www.adventistarchives.org/DocArchives.asp
} 
demonstrate, fitness, government, honor, 144,000, image, intercessor, Job, judgment, latter rain, law, mediator, perfect, preparation, priest, reflect, Satan, seal, sin, spotless, temptation, test, time of trouble, translation, trial, vindicate, witness. The 2008 version of the Ellen White published writings on CD, which included a large addition to the 1995 Words of the Pioneers CD, was not released until 2009. This database added many works of E. J. Waggoner's, among other added sources, that were not included in the 1995 edition. Only a partial search, using a few key words, was made of this new collection.

\section{Outline of the Study}

The findings of the research are presented in two parts. After this introductory chapter 1, chapters 2 and 3 focus on the views of Ellen White and other Adventist leaders contemporaneous with her. Chapter 2 considers the period from the formation of Adventist beliefs in the late 1840s until the 1888 General Conference session, when A. T. Jones and E. J. Waggoner, later seen as influential on Andreasen's final-generation concepts, rose to prominence. Chapter 3 continues with an examination of the period from the 1888 General Conference session to the death of Ellen White in 1915. Chapter 4 examines the views of Andreasen and other Adventist writers during the years 19151937. Chapter 5 is a comparison of Andreasen's views with those of other Adventist writers examined in chapters 2-4, which spans the entire history of the Advent movement until the writing of his The Sanctuary Service in 1937. Chapter 6 summarizes the findings of the study, makes some conclusions, and offers some suggestions for further study. 


\section{CHAPTER 2}

\section{FOUNDATIONS FOR A FINAL-GENERATION THEOLOGY,}

1846-1888

\section{Introduction}

In order to analyze fairly the final-generation motif of M. L. Andreasen, it is helpful to notice the history of related ideas among thought leaders of the sabbatarian Adventists and influential writers of the newly developing Seventh-day Adventist church. This chapter will examine ideas expressed during the period 1846-1888, beginning with the first articles published by those who would form the nucleus of the sabbatarian Adventists, as well as O. R. L. Crosier's influential study of the heavenly sanctuary. The end of this period is marked by the 1888 General Conference session, at which A. T. Jones and E. J. Waggoner began their rise to prominence, whose views in many respects may have served to nourish those of Andreasen. Relevant passages from their works will be examined in the next chapter, which treats the period from 1888-1915.

The purpose of this review is to discover the seeds that sprouted eventually into the full-blown theology of a last generation that overcomes sin completely and whose witness wins the day for God in the court of the universe. Authors and passages are selected therefore not necessarily with the intent of providing a balanced representation of 
ideas, but rather with the object of extracting possible antecedents to Andreasen's concepts.

Fuller attention is paid to the first expression of relevant beliefs and ideas. Thus the first writers examined, O. R. L. Crosier and Joseph Bates, are given relatively more attention, as their views were influential at a time when Ellen White had not yet become authoritative. As White did quickly become very influential, and also for the fact that Andreasen was an avid student of her writings, a good deal of space is then given to ideas expressed in White's writings that seem related to Andreasen's final-generation theology, notably the condition of the saints during the closing events, and the question of the vindication of God in the great controversy theme that she portrayed. White's writings are studied chronologically, so that often certain ideas are repeated, but again with more attention the first times that phrases or concepts are expressed.

The final part of the chapter examines other writers of the period, taking first the most highly regarded pioneers, James White, J. N. Andrews, and Uriah Smith, all of whom wrote extensively. Then somewhat less prominent writers are noted, selected largely for the saliency of their views.

\title{
Crosier's Understanding of the Day of Atonement Antitype
}

\author{
Early Publishing Activities
}

Owen Russell Loomis Crosier (1820-1913), in 1846, wrote out in detail the conclusions to which a small group of Millerites had come in regard to the antitypical Day of Atonement. Crosier was closely associated with Hiram Edson, who is known to Seventh-day Adventists for his visionary experience on the day after the Disappointment 
of October 22, 1844, in which he saw Christ going into the Most Holy Place of the heavenly sanctuary. During the winter following the Disappointment, Crosier stayed with Dr. Franklin B. Hahn, of Canandaigua, NY, and participated in intense Bible study with Hahn and Edson on the subject of the cleansing of the sanctuary. ${ }^{1}$ The three came to the conclusion that the Seventh Month Movement that had pointed to October 22, 1844, the Day of Atonement for that year according to the calendar of the Karaite Jews, was valid. The type, they believed, had been misinterpreted. Rather than depicting Christ's second coming, the Day of Atonement foreshadowed events to take place before Christ returned to earth. This interpretation became critical to the newly evolving sabbatarian eschatology. Crosier joined with Hahn in March 1845 to publish a periodical, the DayDawn, to broadcast these ideas. In the fall of 1845 Enoch Jacobs's Day-Star published letters from Crosier explaining the new understanding, and then in 1846, Crosier, Edson, and Hahn funded a special issue - the Day-Star Extra of February 7. ${ }^{2}$

The Day-Star Extra

\section{Spring Versus Autumn Types}

In this special issue, Crosier set forth the view that the antitypes of the Jewish

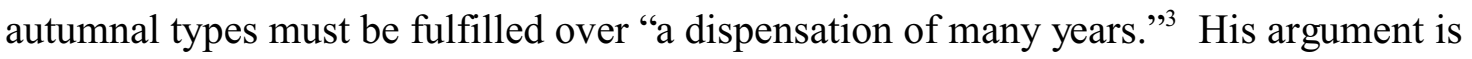

${ }^{1}$ Le Roy Edwin Froom, The Prophetic Faith of Our Fathers: The Historical Development of Prophetic Interpretation, 4 vols. (Washington, DC: Review and Herald, 1946-1954), 4:892.

${ }^{2} \mathrm{P}$. Gerard Damsteegt, Foundations of the Seventh-day Adventist Message and Mission (Grand Rapids: Eerdmans, 1977), 104 n. 5; Seventh-day Adventist Encyclopedia, 2d rev. ed. (1996), s.v. "Crosier, Owen Russell Loomis."

${ }^{3}$ O. R. L. Crosier, “The Law of Moses,” Day-Star Extra, February 7, 1846, 37. 
that since the spring feasts met their fulfillment in the life of Christ, but also extended to the second coming of Christ, so the autumnal feasts will occupy a period of time in relation to, and subsequent to, the second coming of Christ. He denies that the Day of Atonement and other autumnal types were fulfilled at the cross. Although "the churches and world believe" that "the atonement was made and finished on Calvary, when the Lamb of God expired," Crosier believes the foundation for this is weak. ${ }^{4}$ In Crosier's view the Day of Atonement type could not have been fulfilled at the cross, since the atonement "cannot be complete till man and the earth shall be delivered from the subjection and consequences of sin." Rather, he sees the cross as only "the beginning of that great system of redemption whose shadows were contained in the law."

Crosier noticed that one object of the Day of Atonement was that the Israelites might "be clean from all [their] sins before the LORD" (Lev 16:30). He points out that the New Testament looks forward to a coming age when sins will be blotted out and final atonement will be realized. Peter spoke of "the times of refreshing" and "the times of restitution of all things" (Acts 3:19, 21), which Crosier identifies with Paul's "dispensation of the fullness of times" (Eph 1:10), and the antitype of the OT Day of Atonement. In Crosier's view, the antitype of the Day of Atonement cannot be the moment of Christ's coming, but "must begin long enough before the 1000 years" in order "to give time for the cleansing of the Sanctuary, and the antitype of confessing and

${ }^{4}$ Ibid., 41.

${ }^{5}$ Ibid., 37. 
putting the sins on the head of the scapegoat." ${ }^{\prime 6}$ Though Crosier's timing of events may be a little different from later Seventh-day Adventist eschatology, as, for example, when he states that the people were not cleansed completely even when the scapegoat (identified as Satan) had carried away their iniquities, the idea of an end-time cleansing of sanctuary and people is foundational for Adventist eschatology. ${ }^{7}$

\section{Significance of the Day of Atonement}

Cleansing of the sanctuary

That the autumnal types are by Crosier associated with a period of time at the end of the Christian era is clear. What is of more interest to this study is exactly what Crosier envisioned when he spoke of the sanctuary or the people being cleansed. As far as the sanctuary itself is concerned, Crosier points out that in the type the sanctuary bore the iniquity of the Israelites (Num 18:1), "which it had received from them. And this transfer of iniquity from the people to their Sanctuary was not a mere casualty ... but it was according to the original arrangement and regular operation of this typical system."» Crosier argues that the antitypical sanctuary's defilement must have come from human uncleanness, also. But since it is far removed from the earth, and has been entered only by Christ, the heavenly sanctuary "can only be defiled by mortals through His agency, and for them cleansed by the same agency." No inquiry is made as to the reason

${ }^{6}$ Ibid., $42-43$.

${ }^{7}$ Ibid., 42.

${ }^{8}$ Ibid., 40.

${ }^{9}$ Ibid., 42. 
Christ bears human sin into the sanctuary above, apparently only for its defilement and subsequent cleansing.

Cleansing of the people

A major component of the Day of Atonement services was the cleansing of the people from all sins (Lev 16:30). Even though they had already been freed from their sins by the previous atonement made in the daily service, there was this further cleansing revealed, which Crosier sees as a type of what the NT calls "the dispensation of the fulness of times" (Eph 1:10). Now sins that have previously been forgiven are blotted out.

While Crosier uses the term atone to refer to both the daily and yearly service, he emphasizes the difference between the daily service, where sins were "forgiven by the atonement made" in the Holy Place, and the yearly service, where the high priest entered the Most Holy Place "to make an atonement to cleanse them, that they may be clean from all their sins." The daily service for the forgiveness of individuals' sins "may be called the daily atonement," while the blotting out of the nation's sin is termed "the yearly atonement."10 Again, he gives the following as words used to signify the same thing- "bringing into favor with God" by means of blood: atone, cleanse, reconcile, purify, pardon, sanctify, hallow, forgive, justify, redeem, and blot out. ${ }^{11}$ In contrast to the

${ }^{10}$ Ibid., 40.

${ }^{11}$ Ibid., 39-40. 
concept of atonement is the burning of incense and the daily burnt offerings, which are seen as "a sort of continual intercession."

Crosier gives some hint as to the relationship between the daily service of forgiveness, and the yearly service of blotting out of sin. As an example, he points to the cleansing of the leper by Jesus (Mark 1:41-44). After Jesus rid him of the disease, he still needed to offer something for his cleansing. So, the Israelites were freed from their sins by the daily service, but only "to prepare them for the yearly cleansing." Crosier is not altogether clear on the nature of this antitypical "cleansing" of God's people. Though he foresees "bitter persecutions" and a "severe and searching trial of God's people, after the Sanctuary is cleansed," no connection is made between this time of trouble for the saints and their Day-of-Atonement cleansing. ${ }^{13}$ Rather, Crosier seems to envision a time when the "vile bodies" of God's people are changed prior to the final cleansing of atonement. He feels this last purifying act may even be a literal sprinkling with water by God "after he has gathered them into their own land" (cf. Ezek 36:24, 25). Crosier interprets this to be after the resurrection - "after bringing them up out of their graves into the land of Israel. ${ }^{14}$

From the preceding discussion, three significant points may be noted. First, the concept of atonement is clearly not reserved for the Most Holy Place service. The daily service also encompassed atonement for sins. What Crosier vigorously opposed was the

\footnotetext{
${ }^{12}$ Ibid., 39.

${ }^{13}$ Ibid., 43.

${ }^{14}$ Ibid., 42.
} 
idea that atonement was finished at the cross. Atonement could only occur when sin is rid from the universe. Second, Crosier pointed out a need for cleansing of God's people, even after they are freed from sin by the atonement/forgiveness achieved by the daily service. Though he is not sure what this entails, he believes it will be after the resurrection, and thus not confined to the generation living during the time of the cleansing of the heavenly sanctuary. Third, Crosier is rather silent on the significance of the defilement/cleansing of the heavenly sanctuary. Though he points out the reality of its defilement by the sins of God's people, following the biblical evidence, he does not attempt to address the purpose or meaning of such defilement/cleansing.

\section{Joseph Bates's View of the Cleansing of the Sanctuary}

The second major writer to take up the themes of the Crosier-Edson-Hahn study group was Joseph Bates (1792-1872). Bates, active in the Millerite movement since 1839 , early in 1845 accepted the seventh-day Sabbath after reading an article by T. M. Preble in The Hope of Israel. ${ }^{15}$ Pairing this new discovery with Crosier's idea of an ongoing Most Holy Place ministry prior to Christ's second advent, Bates was the first Adventist to point to the importance of perfect obedience to God's law as a preparation for the saints' entrance into their promised inheritance. As Adventist historian George Knight has shown, Bates was the chief architect of what was to become Seventh-day Adventist theology. ${ }^{16}$

\footnotetext{
${ }^{15}$ Seventh-day Adventist Encyclopedia, 2d rev. ed. (1996), s.v. "Bates, Joseph."

${ }^{16}$ See George R. Knight, Joseph Bates: The Real Founder of Seventh-day Adventism (Hagerstown, MD: Review and Herald, 2004).
} 


\section{The Voice of God and a Cleansed People}

Bates issued at least six pamphlets from 1846-1850. In the first, The Opening Heavens, which appeared in the spring of 1846, he labors to show the literalness of the heavenly sanctuary, which he equates with the New Jerusalem. This was against the spiritualizing tendency observed among a great number of Millerites of the time, who tried to persuade themselves that Christ had indeed returned in 1844 — only in a nonphysical manner. ${ }^{17}$ Bates points to the open space in the sword of the constellation Orion as the likely place from which the Holy City will descend to earth. ${ }^{18}$ Significantly, he attaches great meaning to the words of the prophet Joel, that God "will roar out of Zion, and utter his voice from Jerusalem; and the heavens and the earth shall shake" (Joel 3:16, 17). Bates emphasizes that at the time God's voice is thus heard, coming, as he envisions, through the open space in Orion, God's people will be cleansed, or, as Joel puts it, "holy" (vs. 17). ${ }^{19}$

In subsequent pamphlets Bates enlarges on this theme of a holy people emerging when God's voice shakes the earth and heavens. A year later, in Second Advent Way Marks and High Heaps, his first historical work, Bates reaffirms that "when God speaks and shakes earth and heaven, Joel says Jerusalem will be holy, the sanctuary will be

\footnotetext{
${ }^{17}$ Joseph Bates, The Opening Heavens: Or a Connected View of the Testimony of the Prophets and Apostles, Concerning the Opening Heavens Compared with Astronomical Observations: And of the Present and Future Location of the New Jerusalem, the Paradise of God (New Bedford, [MA]: Press of Benjamin Lindsey, 1846; reprint, as pp. 1-39 of Bates' Pamphlets, Payson, AZ: Leaves-of-Autumn Books, 1987), 22. (Page numbers in references with reprints always correspond to the reprint edition.)

$$
\begin{aligned}
& { }^{18} \text { Ibid., 6-12. } \\
& { }^{19} \text { Ibid., } 9 .
\end{aligned}
$$
}


complete, the atonement finished." ${ }^{20}$ In his 1848 Vindication of the Seventh-day Sabbath and the Commandments of God, he gives a fuller picture of the perfecting of the saints. "A sealing process" is seen to be "completed ... in the agonizing time of Daniel's and Jacob's trouble, and proclaimed to the world by God's roaring out of Zion, and uttering his voice from Jerusalem." Again citing Joel 3:16, 17, Bates declares that "their atonement will be finished, the Sanctuary cleansed."21 Thus, for Bates, the sealing process extends up to just before the coming of Christ.

\section{Complete Sanctification in Connection with the Sabbath}

Bates was influential in promoting the seventh-day as the true Sabbath among the scattered Millerites who believed the 1844 date was correct. He saw great importance in the recovery of this lost commandment, since without the keeping of the true seventh-day Sabbath, no company could be clothed in white, nor fulfill the prophecy of Rev 14:12: "Here are they that keep the commandments of God, and the faith of Jesus." Bates contends:

[John] could not nor does he say that those from whom they had separated kept the commandments; but this last company had been keeping nine of them, (or they could not have been made white, ) but John does not give them or the others any credit for keeping a part, for James has said they were a perfect law and "if we offended in one point, we should be guilty of all." Therefore as soon as he saw them keeping the fourth commandment which had been trampled under feet, he cries out, "Here are they that keep the commandments of God.".22

Thus an early connection is here made between obedience to the whole law, and the

\footnotetext{
${ }^{20}$ J. Bates, Second Advent Way Marks, 102.

${ }^{21}$ J. Bates, Vindication of the Seventh-day Sabbath, 214.

${ }^{22} \mathrm{~J}$. Bates, Second Advent Way Marks, 111.
} 
triumph of God's forces at the end, as depicted in Bible prophecy.

Bates seems to go even further in uplifting the significance of the Sabbath in the 1847 revision of his 1846 Seventh Day Sabbath, in connection with sanctification: "So with the Sabbath it is the main and essential thing. It is clearly [sic] that if we keep this holy as God has shown us, then we shall be SANCTIFIED. So we see a holy sanctified soul cannot violate the commandments. ${ }^{23}$ Bates seems to be saying here that it is by the fact of keeping the Sabbath that one is sanctified, and not that the Sabbath serves as a vehicle for one's sanctification. Sanctification is thus equated with perfect obedience to the entire law, the Sabbath being the commandment that is lacking in observance among Christians, and thus standing in the way of their being sanctified. From a twenty-firstcentury viewpoint, Bates seems to assume much in regard to the obedience that is being shown by God's people, who are to be assumed as keeping nine out of the ten commandments. Although the Sabbath is identified as the "main and essential" core of the law, it seems that its observance serves as the mark of the saints' sanctification chiefly because it is the one commandment that has not been heretofore widely observed by Christians - the one thing that is lacking.

\footnotetext{
${ }^{23}$ Joseph Bates, The Seventh Day Sabbath: A Perpetual Sign from the Beginning to the Entering into the Gates of the Holy City According to the Commandment, 2d. rev. and enl. ed. (New Bedford: Benjamin Lindsey, 1847; reprint, as pp. 51-115 of The Sabbath Controversy, Payson, AZ: Leaves-of-Autumn Books, 1987), 110.
} 
The Sealing Process and the Cleansing of the Sanctuary

\section{Trial Before Sins Blotted Out}

In order for God's people to be sealed, and sanctuary and people cleansed, they must be placed on trial, as Bates understands it. In 1849 Bates wrote a 72-page pamphlet on the sealing of the 144,000 , entitled A Seal of the Living God. Here he points to the keeping of the Sabbath as the test that God uses to prove the loyalty of His people. Though the saints plead for their High Priest to blot out their sins on the antitypical Day of Atonement, "this cannot be accomplished until he has tried them, and humbled them, to prove them, to know what is in their hearts, whether they will keep his commandments or no." 24 As Bates sees it, only conscientious Sabbath keepers can be sealed as part of the 144,000: "None but Sabbath keepers and believers can ever be sealed with this seal, and even many of them will fail unless they keep the Sabbath holy in its appointed time, for it is just as sinful in the sight of God to willfully reject the Bible light on the commencing of the Sabbath, and therefore transgress a part of sacred time, as it would be not to keep it at all." 25

Bates sees this testing process as analogous to the affliction that the Israelites experienced on the typical Day of Atonement, while their high priest was in the Most Holy Place. For the saints at the end of time, however, this period of trial is not just one day, but the entire period from October 22, 1844, "until God roars out of Zion and utters his voice from Jerusalem. . . . According to the signs given by Jesus, the next after this

\footnotetext{
${ }^{24}$ J. Bates, Seal of the Living God, 20.

${ }^{25}$ Ibid., 38 .
} 
will be the sign of the son of man in heaven." ${ }^{26}$ Bates sees a parallel between John's words in Rev 14:12 regarding the "patience [endurance] of the saints" and the affliction of the Israelites on the Day of Atonement: "The true meaning of the cleansing of the sanctuary is, Christ our high priest in the sanctuary ... making atonement, or blotting out the sins of his true waiting people; and while he is doing this, they are in their trial. 'Here is the patience of the Saints,' as it was in the type referred to. ${ }^{.27}$ Bates thus sees a period of testing undergone by the saints to determine whether they are truly loyal to God's commandments or not, in preparation for receiving God's seal.

\section{Perfecting of the Saints as a Preparation}

The time of testing that Bates speaks of, though, is not identical with what Adventists have come to understand as the post-probationary "time of trouble" that directly precedes the Second Advent. Rather, Bates's period of trial runs concurrently with the sealing work and the cleansing of the heavenly sanctuary, and has as its purpose the preparation of God's people for the "time of trouble, such as never was" (Dan 12:1). ${ }^{28}$

Using the wedding imagery familiar to the Millerite believers, Bates, in Second Advent Way Marks and High Heaps, locates this period of preparation between the

${ }^{26}$ J. Bates, Vindication of the Seventh-day Sabbath, 202.

${ }^{27}$ Ibid.

${ }^{28}$ It should be kept in mind that Bates and the "shut-door" Adventists believed that probation had ended in 1844 with the beginning of the cleansing of the sanctuary. The testing of God's people was all in post-probationary time. Bates was teaching that it was possible for Adventists to fall during this time if they did not receive the seal, and were found to be disobedient. Seventh-day Adventists today hold that the sealing work continues until the close of probation, at which point the destiny of all persons is fixed. 
marriage of the Lamb and the marriage supper. Bates understands that "Jesus after his marriage [must] enter the Holiest of Holies, and commence the cleansing of the sanctuary." 29 The small group of Millerite Adventists who subscribed to the EdsonHahn-Crosier conclusions believed this to have occurred in 1844 , at the close of the 2300 days of Dan 8:14. They believed that they had fulfilled the role of the five wise virgins in the parable of Matt 25:1-13, who had gone into the wedding with the Bridegroom before the door was shut.

Bates wishes to shake such believers out of any premature sense of security. Those "shut into the guest chamber" with the Bridegroom should not think they are thereby "sealed and safe." 30 It was not enough to be among the ones who went into the marriage. Bates points out that, according to Rev 19:9, only those called to the marriage supper are blessed. Before this was the time for the inspection of the guests to see whether they had put on the wedding garment (Matt 22:1-14). Bates points out that one guest in the parable was found to be without a wedding garment. Interpreting this garment as the "fine linen, clean and white ... the righteousness of saints" (Rev 19:8), Bates concludes that it is because this guest's "obedience was incomplete" that he was thrown out. So, many Adventists "would not endure the trial that they should be plunged into between the marriage and the supper" which "comes to purge and fan out the chaff from the wheat." 31

\footnotetext{
${ }^{29}$ J. Bates, Second Advent Way Marks, 104.

${ }^{30}$ Ibid., 106.

${ }^{31}$ Ibid.
} 
In Bates's view, the trials that the saints undergo between the marriage and the supper serve not only to distinguish the true followers from the false, but also serve, "if they endure them patiently," to prepare them for the marriage supper. ${ }^{32}$ By a "process of purifying, being made white, and tried," the saints are prepared to enter the holy city. ${ }^{33}$ This is the task of the cleansing of the sanctuary, which serves practically to purify the saints "to enter into the holy city." ${ }^{\prime 34}$ Being prepared to enter Paradise, those who are sealed, or sanctified, are enabled "to pass safely through the time of trouble," a point Bates makes repeatedly in his 1849 pamphlet on the seal of God. ${ }^{35}$

The purifying process that Bates envisions is not merely a blotting of sin from the record books of heaven. Rather, he emphasizes righteous living as he concludes his 1849 study on the sealing work: "And let us carefully seek to know 'what manner of person [sic] we ought to be in all holy conversation and godliness' [2 Pet 3:11], seeing that we have now entered upon the last work or message, that God has marked out for his church before their final deliverance from this time of trouble, such as never was." ${ }^{.36}$ And in 1847 Bates had written that "none can go in [through the narrow gate that leads to life] short of perfect obedience to God. ${ }^{{ }^{37}}$ The next year he spoke of Christ's cleansing work in the Most Holy Place of the heavenly sanctuary as involving the "saints being perfected

${ }^{32}$ Ibid., 107.

${ }^{33}$ J. Bates, Opening Heavens, 33.

${ }^{34}$ J. Bates, Vindication of the Seventh-day Sabbath, 226.

${ }^{35}$ J. Bates, Seal of the Living God, 40. See also pp. 1, 46, 62, 64.

${ }^{36}$ Ibid., 67.

${ }^{37}$ J. Bates, Second Advent Way Marks, 107. 
for the blessing when [Christ] lays aside his priestly robes and takes the sickle, as in Rev.14:14; and God speaks, as in Joel 3:16." ${ }^{\prime 38}$ As we have seen, Bates emphasized that Jerusalem will be holy when God's voice is thus heard shaking heaven and earth. ${ }^{39}$ So here again Bates points forward to a time of complete obedience on the part of the saints just prior to Christ's return. Later in the same work Bates make the point more definitely when he speaks of the sealing work: "This ... sealing of the 144,000 will show such a clear developement [sic] of Christian character in their lives and shining foreheads (or faces,) that it will be clearly understood that Jesus has redeemed them from all iniquity." ${ }^{\circ 40}$

"Development of Christian character," for Bates, includes getting the victory over all manner of fleshly indulgences, as he emphasized in his 1849 work on the sealing. No one could expect to receive God's seal while using or trafficking in tobacco or alcohol, Bates argued. Speaking of tobacco, he asserts, "I see not how God can seal you to be one of his royal priesthood while he frowns upon it. The one who traffics in it certainly cannot be justified." ${ }^{41}$ He was equally opposed to alcohol: "I know not how God can approbate one of the 144,000 that uses or traffics in alcoholic drinks, from brandy to cider, and beer." ${ }^{, 42}$

${ }^{38}$ J. Bates, Vindication of the Seventh-day Sabbath, 187.

${ }^{39}$ See pp. 21-22 above.

${ }^{40}$ J. Bates, Vindication of the Seventh-day Sabbath, 214.

${ }^{41}$ J. Bates, Seal of the Living God, 67. Ellen White in 1851 wrote of having a vision in which an angel expressed the impossibility of tobacco users receiving God's seal. James White later placed this vision in 1848, which would precede Bates's statement here. See p. 34 n. 56 below.

${ }^{42}$ Ibid., 68. 
It seems clear that Bates greatly advanced the Crosier-Edson-Hahn concept of an antitypical Day of Atonement occurring at the end of earth's history. Whereas Crosier suggested a final physical purification of the saints after the resurrection, Bates foresaw a thorough moral cleansing of the saints before Christ ended His work in the Most Holy Place. He envisioned a people made holy, purified from all iniquity and fleshly lusts, and this to be completed a short time before the Second Advent, when God's voice is to be heard, shaking the heavens and the earth. Also, by connecting the Sabbath commandment to the process of sanctification, Bates highlighted the importance of perfect obedience to God's law as a requirement for an end-time sealing work and the finishing of the atonement.

\section{Ellen White's Views of End-Time Events}

When Crosier and Bates published their views on the significance of the Old Testament sanctuary services for the post-Disappointment Adventist believers, a young woman living in Portland, Maine, had already received visions regarding the Adventist believers and Christ's work in the heavenly sanctuary. Ellen Gould Harmon (1827-1915) was only twelve years old when she was introduced to the teachings of William Miller during one of his visits to Portland, Maine, in 1840. She received her first vision in December 1844, and shortly thereafter began a lifelong ministry of guiding and exhorting Adventists. She was assisted by a young Adventist minister, James White, whom she married in $1846 .{ }^{43}$ For those who accepted her visions as inspired by God, her teachings

\footnotetext{
${ }^{43}$ Seventh-day Adventist Encyclopedia, 2d rev. ed. (1996), s.v. "White, Ellen Gould (Harmon)."
} 
in regard to the sanctuary served to validate the views of Crosier and Bates.

Focus on the 144,000 in Her First Visions, 1844-1845

Two weeks before Crosier's major article appeared in the Day-Star, editor Enoch Jacobs printed a letter from Ellen Harmon in the January 24, 1846, issue, in which she presented two of her first visions. ${ }^{44}$ Six times in this account mention is made of "the 144,000 ," that special group mentioned in chaps. 7 and 14 of Revelation, who receive the seal of God and have "the Father's name written in their foreheads" (Rev 14:1). She reports seeing in vision the names of the 144,000 "engraved in letters of gold" on tables of stone in the heavenly temple, a place only these 144,000 were permitted to enter. ${ }^{45}$

Harmon emphasizes the unique experience of the 144,000 in connection with an end-time sealing, noting that this group, seen in vision, were "all sealed and perfectly united. On their foreheads was written, God, New Jerusalem, and a glorious star containing Jesus' new name. ${ }^{, 46}$ Similarly to Bates ${ }^{47}$ Harmon draws attention to the voice

${ }^{44}$ According to Arthur White, she appended to her first vision, received in December 1844, a description of the new earth, gained from a vision she received in the spring of 1845. See Arthur L. White, Ellen G. White, 6 vols. (Washington, DC: Review and Herald, 1981-1986), 1:88.

${ }^{45}$ E. G. White, Early Writings, 19. For the original article, see Ellen G. Harmon, "Letter from Sister Harmon. Portland, Me., Dec. 20, 1845," Day-Star, January 24, 1846; reprint, in Ellen G. White, Ellen G. White Periodical Resource Collection, comp. the Ellen G. White Estate (Boise, ID: Pacific Press, 1990), 2:189-190 (original, 31-32). It is interesting to note that this reference to tables of stone in the heavenly sanctuary omits any mention of the Sabbath or even the ten commandments as such. She did not begin observing the seventh-day Sabbath of the fourth commandment until the autumn of the same year. See Ellen G. White, Testimonies for the Church, 9 vols. (Mountain View, CA: Pacific Press, 1948), 1:75.

${ }^{46}$ E. G. White, Early Writings, 15 . Here again, we note the absence of mention of the Sabbath, which would later be identified with this seal by a growing group of 
of God heard at the end of time, just before the return of Christ to earth: "The living saints, 144,000 in number, knew and understood the voice, while the wicked thought it was thunder and an earthquake. When God spoke the time, He poured upon us the Holy Ghost, and our faces began to light up and shine with the glory of God, as Moses' did when he came down from Mount Sinai. ${ }^{948}$ Here an implicit connection can be seen between an end-time outpouring of the Holy Spirit and an experience of unusual holiness and intimacy with God. ${ }^{49}$

This portrayal of an experience of holiness on the part of the 144,000 at a point in time just prior to the Second Coming is independent of any later focus on law and obedience. Even though, in a vision a few months later, Harmon saw the ark of the covenant in the Most Holy Place of the heavenly sanctuary, she did not see the Ten Commandments, but only the tables of stone with the names of the 144,000 "engraved in

sabbatarian Adventists, including Ellen White and Joseph Bates. See J. Bates, Seal of the Living God; Ellen G. White, To Those Who Are Receiving the Seal of the Living God (Topsham, [ME], 1849; reprint, Battle Creek, MI: Belden Reprints, 1938). The latter is found on pp. 36-41 and 56-58 of E. G. White, Early Writings.

${ }^{47}$ See pp. 21-22 above.

${ }^{48}$ E. G. White, Early Writings, 15.

${ }^{49}$ Only in this earliest vision do we see an outpouring of the Holy Spirit coinciding with the sounding of the voice of God and the shining of the saints' faces. The Holy Spirit is not mentioned in connection with later references to the voice of God and the lighting up of the saints' faces. Ibid., 34, 37, 285-286; E. G. White, Spirit of Prophecy, 4:429-431; idem, Great Controversy, 640. Starting in 1847 (going by White's 1854 explanation), White describes an outpouring of the Holy Spirit prior to the close of probation, while the faces of the saints are also seen to shine in connection with this outpouring and the giving of the "loud cry" message. E. G. White, Early Writings, 33, 85, 278-279; idem, Spirit of Prophecy, 4:458; idem, Great Controversy, 611-612. 
letters of gold," the golden pot of manna, and Aaron's rod inside the ark. ${ }^{50}$

We thus find holiness highlighted in this early description by Harmon of the experience of the 144,000 , but without the later emphasis on the law and the Sabbath. In addition, a notable balance is observed between law and grace in Harmon's portrayal of this special group at the moment of the second coming of Christ. They cry out, "'Who shall be able to stand? Is my robe spotless?"' This anxiousness in regard to needed purity on their part seems echoed by the angels, who "ceased to sing." After a period of “awful silence," Jesus both confirms and allays their concern, saying, "'Those who have clean hands and a pure heart shall be able to stand; My grace is sufficient for you."” Harmon adds that "at this, our faces lighted up, and joy filled every heart."

\section{Early Sketches of Needed Preparation for the Time of Trouble, 1845-1849}

Sometime late in 1845, Harmon had a vision of a future "time of Jacob's trouble," before which all the Advent believers "received the seal of the living God." Cries for deliverance ascended until Christ left the Most Holy Place of the heavenly sanctuary, after which the voice of God was heard "which shook the heavens and earth." This, along with her first visions, was published in April 1846 on a broadside (a large

${ }^{50}$ Harmon, "Letter from Sister Harmon, Portland, Me.," 32. This part of the spring 1845 vision was not included in Early Writings, but was early reprinted in James White, ed., $A$ Word to the "Little Flock" (Gorham, ME: [by the editor], 1847; reprint, as Part I of George R. Knight, ed., Earliest Seventh-day Adventist Periodicals, with an introduction by George R. Knight, Adventist Classic Library, ed. George R. Knight, Berrien Springs, MI: Andrews University Press, 2005), 16-17. Regarding this silence on what came to be a central component of Seventh-day Adventist belief (i.e., the law and the seventh-day Sabbath), see also pp. 30-31, nn. 45-46 above.

${ }^{51}$ E. G. White, Early Writings, 16. 
single sheet of paper) with the help of James White. ${ }^{52}$ Then, in 1847, James White included most of this material in his Word to the "Little Flock. ",53 Also appearing in this twenty-four-page pamphlet is Ellen White's ${ }^{54} 1847$ letter to Joseph Bates, in which she relates a recent vision that portrays end-time events. Here again she speaks of the voice of God shaking the heavens and the earth after the saints "cried day and night for deliverance" during the time of trouble. Prior to this they "were filled with the Holy Ghost" as they went forth to proclaim the Sabbath at the beginning of a time of trouble preceding the pouring out of the last plagues. ${ }^{55}$

\section{Blotting Out of Sins before Christ Leaves the Sanctuary}

By means of a number of conferences in 1848 , a small group of sabbatarian Adventists emerged and quickly began to publish the next year. In January 1849 Bates issued his Seal of the Living God, while in the same month Ellen White issued a broadside entitled "To Those Who are Receiving the Seal of God." Just as Bates in his pamphlet emphasized the preparation necessary for believers to pass safely through the

${ }^{52}$ Ellen G. Harmon, To the Little Remnant Scattered Abroad (Portland, ME, 1846); A. White, Ellen G. White, 1:127.

${ }^{53}$ J. White, ed., A Word to the "Little Flock," 14-18.

${ }^{54}$ Ellen Harmon had married James White in August 1846.

${ }^{55}$ E. G. White, Early Writings, 33-34. For the original, see Ellen G. White, Topsham, ME, to Brother [Joseph] Bates, April 7, 1847, Letter 1, 1847, CAR, published as component of James White, ed., A Word to the "Little Flock" (Gorham, ME: [by the editor], 1847; reprinted as Part I of George R. Knight, ed., Earliest Seventh-day Adventist Periodicals, with an introduction by George R. Knight, Adventist Classic Library, ed. George R. Knight, Berrien Springs, MI: Andrews University Press, 2005), 19. 
coming time of trouble, ${ }^{56}$ White also focused on the sealing of the 144,000 as a preparation for their time of trouble. She stresses that "the sealing time is very short, and soon will be over," that "the time for Jesus to be in the most holy place was nearly finished," according to what she had seen, and that only those with "clean hands and a pure heart" would "stand that trying time." God's law, which includes the Sabbath-seal, must be written in mind and heart. ${ }^{57}$ In the same broadside, White made one of the first statements regarding the significance of the ending of the work of Christ in the heavenly sanctuary, noting that Christ would "step out from between the Father and man," which permits the wrath of God to be poured out on the rejecters of truth. ${ }^{58}$ When her first book was published two years later, she would enlarge on this theme of living on earth without a High Priest in the heavenly sanctuary. ${ }^{59}$

It was also in this year that James White began publishing The Present Truth, to which his wife also contributed. In the fourth issue of this paper, Ellen White made her

\footnotetext{
${ }^{56}$ See pp. 25-29 above. According to a vision which James White dated to the fall of 1848, Ellen White was shown that tobacco users "cannot be sealed with the seal of the living God." Ellen G. White to Brother Barnes, December 14, 1851, Letter 5, 1851, published, in part, in Manuscript Releases: From the Files of the Letters and Manuscripts Written by Ellen G. White, 21 vols. (Silver Spring, MD: E. G. White Estate, 1981-1993), 5:377; James White, "Western Tour," Advent Review and Sabbath Herald, November 8, 1870, 165. See also Ellen G. White, Selected Messages from the Writings of Ellen G. White: Significant and Ever-Timely Counsels Gathered from Periodical Articles, Manuscript Statements, and Certain Valuable Pamphlets and Tracts Long out of Print, 3 vols. (Washington, DC: Review and Herald, 1958-1980), 3:272-273.

${ }^{57}$ E. G. White, Early Writings, 58. For the original, see E. G. White, To Those Who Are Receiving the Seal of the Living God.

${ }^{58}$ E. G. White, Early Writings, 36.

${ }^{59}$ See pp. 37-38 below.
} 
first reference to the blotting out of the sins of those who are sealed, in connection with

Christ's closing work in the heavenly sanctuary. In this short exhortation of a few

paragraphs, White calls upon believers to be faithful during their present time of trial, for

Christ would soon leave the sanctuary:

Jesus is in His holy temple and will now accept our sacrifices, our prayers, and our confessions of faults and sins and will pardon all the transgressions of Israel, that they may be blotted out before He leaves the sanctuary. When Jesus leaves the sanctuary, then they who are holy and righteous will be holy and righteous still; for all their sins will then be blotted out, and they will be sealed with the seal of the living God. But those that are unjust and filthy will be unjust and filthy still; for then there will be no Priest in the sanctuary to offer their sacrifices, their confessions, and their prayers before the Father's throne. Therefore what is done to rescue souls from the coming storm of wrath must be done before Jesus leaves the most holy place of the heavenly sanctuary. ${ }^{60}$

Here we see a clear demarcation between the time before and after Christ finishes His Most Holy Place ministry, with pardon for sinners obtainable only while He lingers in the sanctuary. The work to be accomplished appears to be principally a confession of sins, so that they might be blotted out, with an accompanying sense of urgency in relation to the fast-closing window of opportunity for the salvation of others.

\section{Satan's Efforts to Deceive}

Besides emphasizing the preparation needed to escape the wrath of God that is poured out after the close of probation, Ellen White at this time further developed the idea that Satan was doing his utmost to keep people deceived until it was too late. She had first drawn attention to the work of the devil in deceiving believers at the end of time in relating her second vision, which dealt with the transfer of Christ's work to the Most

${ }^{60}$ E. G. White, Early Writings, 48. For the original, see Ellen G. White, "Dear Brethren and Sisters," Present Truth, September 1849, 32. 
Holy Place of the heavenly temple. When she speaks of this scene, she states that she saw Satan "by the throne, trying to carry on the work of God." Upon those who prayed toward this throne from which Christ had departed in 1844, Satan "would then breathe ... an unholy influence; in it there was light and much power, but no sweet love, joy, and peace. Satan's object was to keep them deceived and to draw back and deceive God's children." ${ }^{\circ 1}$

Now, in the third issue of Present Truth, Ellen White gives further details regarding the end-time deceptive work of Satan. The thrust of this urgent message is to warn of Satan's efforts to counteract Christ's new ministry in the Most Holy Place. She reveals that "Satan is now using every device in this sealing time to keep the minds of God's people from the present truth and to cause them to waver. I saw a covering that God was drawing over His people to protect them in the time of trouble; and every soul that was decided on the truth and was pure in heart was to be covered with the covering of the Almighty. ${ }^{962}$ She then points to the outbreak of modern spiritualism and the mesmeric influence of certain preachers as ways in which Satan was then at work to create doubt in regard to the validity of what the sabbatarian Adventists were proclaiming as present truth (i.e., the Sabbath as a test post-1844). ${ }^{63}$ Looking ahead to the coming

${ }^{61}$ E. G. White, Early Writings, 56. For the original, see Ellen G. Harmon, "Letter from Sister Harmon. Fulmouth, Mass., Feb., [sic] 15, 1846," Day-Star, March 14, 1846; reprint, in Ellen G. White, Ellen G. White Periodical Resource Collection, comp. the Ellen G. White Estate (Boise, ID: Pacific Press, 1990), 2:191 (original, 7).

${ }^{62}$ E. G. White, Early Writings, 43. For the original, see Ellen G. White, "Dear Brethren and Sisters," The Present Truth, August 1849, 21.

${ }^{63}$ Ibid., 43-45. 
"day of slaughter" in which a protective "covering" would be needed by believers, White points to a cosmic power struggle to be played out, with God working "in power for his people" and Satan "permitted to work also." ${ }^{\circ 4}$ In such passages can be seen early glimpses of what would come to be one of the themes of Ellen White's writings - the controversy between good and evil that culminates at the end of time.

Focus on Preparing for the Time of Trouble, 1850-1857

In following years Ellen White repeatedly urged Adventists to think seriously about what they would need in order to endure the coming time of trouble. Perhaps her clearest early account of the preparation needed to successfully withstand this coming trial is found in her first published book, A Sketch of the Christian Experience and Views of Ellen G. White, issued in August 1851, which in 1882 was reprinted as the first part of Early Writings of Ellen G. White. ${ }^{65}$ In a section entitled "The Holiness of God" and retitled "Preparation for the End" in 1882, she relates a vision she had on May 14, 1851, in which she was presented with the holiness needed by Adventists facing the oncoming time of trouble. In a manuscript written four days after this vision, she describes how her "body shook like a leaf" when "a light coming from the excellent glory that encircled the Father" approached her, and she felt that she "should be dissolved or struck out of existence. ${ }^{" 66}$ From this experience she concludes: "Then could I realize what a terrible

${ }^{64}$ Ibid., 44.

${ }^{65}$ Ellen G. White, A Sketch of the Christian Experience and Views of Ellen G. White (Saratoga Springs, NY: James White, 1851); idem, Early Writings.

${ }^{66}$ Ellen G. White, "Opposition to the Sabbath," MS 5, May 18, 1851, published under the title "The Sabbath and Other Issues in the Conflict" in Manuscript Releases: 
God we have to do with, and that we must be so holy that we can live in His sight. Then I saw how little some realized the holiness of God, and what they must be in order to live in His sight, through the time of trouble. ${ }^{97}$ In the published form, issued in August, she asserts twice that the believers will be passing through this time of trouble without a Mediator in the heavenly sanctuary: "I also saw that many do not realize what they must be in order to live in the sight of the Lord without a high priest in the sanctuary through the time of trouble.... There will be ... no Mediator to plead their cause before the Father. ${ }^{968}$ In this and other passages during the 1850s Ellen White spoke frequently of the preparation necessary to pass safely through this hazardous time.

One of the elements held by the sabbatarian Adventists to be a necessary preparation for the time of trouble was what they termed the "refreshing," or the "latter rain. ${ }^{{ }^{69}}$ Ellen White rebuked those who neglected to prepare in the present, but rather looked "to the time of 'refreshing' and the 'latter rain' to fit them to stand in the day of

From the Files of the Letters and Manuscripts Written by Ellen G. White, 21 vols. (Silver Spring, MD: E. G. White Estate, 1981-1993), 6:168.

${ }^{67}$ Ibid. Cf. her contemporaneous retelling of her fear as a thirteen-year-old, upon hearing Miller's lectures, that she was not holy, and therefore not ready to see Jesus come. Ellen G. White, "Experience and Views," Second Advent Review and Sabbath Herald Extra, July 21, 1851, 1. This is reprinted in idem, Early Writings, 11.

${ }^{68}$ E. G. White, Early Writings, 71.

${ }^{69}$ Acts 3:19; Jas 5:7-8. William Miller had previously spoken of the sealing and the latter rain as end-time occurrences, noting how the winds of strife had been restrained "until the servants of God should be sealed, the latter rain of grace descend, and God's purposes completed concerning this latter day?" William Miller, Evidence from Scripture and History of the Second Coming of Christ About the Year 1843: Exhibited in a Course of Lectures (Boston: J. V. Himes, 1842; reprint, Payson, AZ: Leaves of Autumn Books, 1988), 289. 
the Lord and to live in His sight." She explains in the same passage that this "refreshing" is a necessary preparation, ${ }^{70}$ but that the latter rain itself also requires preparation on the part of believers: "They had neglected the needful preparation; therefore they could not receive the refreshing that all must have to fit them to live in the sight of a holy God."

\section{Purified by Obedience to the Truth}

What was being neglected by Advent believers was a reformation of life, and a complete consecration to God. This is expressed in a number of ways. Believers needed to be purified through obedience to the truth. "Those who refuse ... to purify their souls in obeying the whole truth, and who are willing to believe that their condition is far better than it really is, will come up to the time of the falling of the plagues, and then see that they needed to be hewed and squared for the building." 72 A few months later, in a letter to "Brother and Sister Dodge," White made even more explicit the necessity of purification by the truth, as a preparation for receiving the latter rain: "The refreshing is coming from the presence of the Lord. Let us set our hearts in order that the truth of God may live in us; that it may purify us, ready to receive the latter rain."73 In the same letter,

${ }^{70}$ Also, in 1854, she wrote: “At that time the 'latter rain,' or refreshing from the presence of the Lord, will come, to give power to the loud voice of the third angel, and prepare the saints to stand in the period when the seven last plagues shall be poured out." E. G. White, Early Writings, 86.

${ }^{71}$ Ibid., 71.

${ }^{72}$ Ibid.

${ }^{73}$ Ellen G. White to Brother and Sister Dodge, December 21, 1851, Letter 9, 1851, published, in part, in Manuscript Releases: From the Files of the Letters and Manuscripts Written by Ellen G. White, 21 vols. (Silver Spring, MD: E. G. White Estate, 1981-1993), $8: 228$. 
Ellen White points to sufferings as desirable, in that they are the means of our purification: "I crave the suffering part.... Let me be perfected through sufferings. I long to be a partaker with Christ of His sufferings." ${ }^{.74}$ Again, in an article in the Advent Review and Sabbath Herald the next year, White speaks of craving "the suffering, crucifying part of religion" since "we are to be purified and fitted for the kingdom through suffering." 75

\section{Reflecting the Image of Jesus}

Saints reflecting the image of Jesus perfectly is another way that White expressed this purity of heart and life that Advent believers needed. This thought appears in the same Dec. 21, 1851, letter to the Dodges: "Let us study to have our lives as near like Christ's as possible.... Oh, to reflect His lovely image perfectly! Oh, for to be wholly consecrated to Him!"’6 When writing that same year of the needed preparation for living without a Mediator, White wrote that "those who receive the seal of the living God and are protected in the time of trouble must reflect the image of Jesus fully." ${ }^{, 77}$ A year earlier, her "accompanying angel" had asked, "'Do you reflect the lovely image of Jesus as you should?' . . 'Get ready, get ready, get ready."'78

${ }^{74}$ Ibid., 8:340.

${ }^{75}$ Ellen G. White, "To the Brethren and Sisters," Advent Review and Sabbath Herald, June 10, 1852, 21. See also idem, Testimonies, 1:133.

${ }^{76}$ E. G. White to Brother and Sister Dodge, Manuscript Releases, 4:271.

${ }^{77}$ E. G. White, Early Writings, 71.

${ }^{78}$ Ibid., 64. 


\section{Complete Victory over Sin}

White also expressed this complete consecration in terms of gaining complete victory over sin. In the passage in which she relates her May 14, 1851, vision of the need for holiness on the part of believers anticipating the time of trouble, White speaks of gaining complete victory as a precondition for receiving the latter rain:

I saw that none could share the 'refreshing' unless they obtain the victory over every besetment, over pride, selfishness, love of the world, and over every wrong word and action. We should, therefore, be drawing nearer and nearer to the Lord and be earnestly seeking that preparation necessary to enable us to stand in the battle in the day of the Lord. Let all remember that God is holy and that none but holy beings can ever dwell in His presence." 79

Though not directly relating the concept of complete overcoming to the idea of preparing for the latter rain or the time of trouble, White in 1857 clearly set forth the possibility of complete victory over sin in connection with the Laodicean message: "We can overcome. Yes; fully, entirely. Jesus died to make a way of escape for us, that we might overcome every evil temper, every sin, every temptation, and sit down at last with Him." ${ }^{90}$ As to what she meant by overcoming every evil temper, we may gather a clue from an 1854 Review article in which she states that "unruly children who manifest passion" cannot be preserved in the time of trouble..$^{81}$

Although White condemned as "so-called perfectionism" the view that "those who are sanctified cannot sin," which resulted in the belief that all their affections and

${ }^{79}$ Ibid., 71.

${ }^{80}$ E. G. White, Testimonies, 1:144.

${ }^{81}$ Ellen G. White, "Duty of Parents to Their Children," Advent Review and Sabbath Herald, September 19, 1854, 45. 
desires could be safely indulged, ${ }^{82}$ she seems to be a thoroughgoing perfectionist in what might be termed the biblical sense. In a section titled "Prepare to Meet the Lord" in her first "Testimony for the Church," published in 1855, she says that only "perfect Christians ... escape the seven last plagues. ${ }^{983}$ In connection with preparation for the time of trouble, she reminds readers that the church that Christ will present to His Father is spotless: "I do not want any of you to come up to the time of trouble without a wellgrounded hope in your Redeemer. ... Remember that a church without spot, or wrinkle, or any such thing, will Jesus present to His Father. ${ }^{\circledR 4}$

\section{Confession of Sin and a Deep Experience}

Besides a radical transformation of life and character in preparation for the time of trouble, White in 1854 challenged readers of The Youth's Instructor to search their hearts and confess their sins "to Jesus in the Sanctuary" that they might "have pardon written for all their sins." Contrasting such persons with "those who have lived in sin," she declares that 'they, having purified their souls 'in obeying the truth,' will remain pure and holy forever." ${ }^{155}$ White stresses in an 1855 testimony entitled "Prepare to Meet the Lord" that those preparing to meet Jesus at His second coming "must have a deep and living

${ }^{82}$ E. G. White, Early Writings, 101; idem, Life Sketches of Ellen G. White, Being a Narrative of Her Experience to 1881 as Written by Herself; with a Sketch of Her Subsequent Labors and of Her Last Sickness, Comp. from Original Sources (Mountain View, CA: Pacific Press, 1915), 83.

${ }^{83}$ E. G. White, Testimonies, 1:126.

${ }^{84} \mathrm{Ibid} .$, 1:163. See also E. G. White to Brother Barnes, 8:225.

${ }^{85}$ Ellen G. White, “He Will Come Again,” Youth’s Instructor, April 1854, 29. 
experience. This alone will save them in the time of trouble. ${ }^{966}$ Again, focusing on the deep spirituality that characterizes those who are prepared for the coming trouble, in January 1850 , just after the Sabbath conferences that had turned the attention of the sabbatarian Adventists to the important sealing work, she advised a leading couple to tell their children "to have their lives hid with Christ in God, to have their hearts wholly given to God, that they may be hid in the day of the Lord's anger." ${ }^{\text {, }}$

\section{Sealing Places beyond Satan's Power}

One interesting idea expressed in connection with preparing for the time of trouble is White's comment regarding the apparent effect of the sealing. While describing a vision she had in August 1850, she says she saw Satan working with great power, because "he knows that his time is short and that the sealing of the saints will place them beyond his power." ${ }^{88}$ The precise meaning of being placed beyond Satan's power seems unclear. It seems to imply the impossibility of those sealed falling under the power of temptation, following Rev 22:11: "He that is unjust, let him be unjust still: and he which is filthy, let him be filthy still: and he that is righteous, let him be righteous still: and he that is holy, let him be holy still." They would be beyond Satan's power in terms

${ }^{86}$ E. G. White, Testimonies, 1:125.

${ }^{87}$ Ellen G. White, Oswego, NY, to Brother and Sister Hastings, [New Ipswich, $\mathrm{NH}$ ], January 11, 1850, Letter 18, 1850, published under the title "Better Days Are Coming" in Manuscript Releases: From the Files of the Letters and Manuscripts Written by Ellen G. White, 21 vols. (Silver Spring, MD: E. G. White Estate, 1981-1993), 19:128.

${ }^{88}$ Ellen G. White, “A Vision God Gave Me at Brother Harris', August 24, 1850," MS 7, 1850, extract from pp. 2-3 published under the title "The Open Door" in Manuscript Releases: From the Files of the Letters and Manuscripts Written by Ellen $G$. White, 21 vols. (Silver Spring, MD: E. G. White Estate, 1981-1993), 8:220. 
of his causing them to lose salvation, but not necessarily beyond his power to annoy and tempt, even though he could not make them fall. Or it could merely mean that, being sealed, believers had demonstrated such a wholehearted consecration to God that all future temptation could be deemed a failure from the start. Whether the seal is some kind of covering impervious to Satan's attacks, or simply a sign of total commitment, the question of the condition of the sealed saints after the close of probation and the nature of their ensuing struggle with the forces of evil is an important one for this study. ${ }^{89}$

\section{Satan's Efforts to Prevent Sealing}

While White emphasized the needed preparation for the time of trouble, she continued to strongly warn believers of the determination of Satan to ensnare them, and to thus prevent their sealing. In her 1851 Experience and Views she spent a good deal of effort in revealing the designs of Satan in connection with the development of modern spiritualism, pointing out that "all these great signs and mighty wonders of the devil are designed to deceive God's people and overthrow them." ${ }^{\prime 0}$ She further developed her argument in her 1854 Supplement to the Christian Experience and Views of Ellen G. White, in which she again declared that the recently growing "rapping delusion" was "to deceive the saints and ensnare them into the belief of this delusion," and that "if it were possible it would deceive the very elect." ${ }^{91}$

${ }^{89}$ See pp. 47-48, 62-63 below.

${ }^{90}$ E. G. White, Early Writings, 60. For the original, see idem, A Sketch of the Christian Experience and Views of Ellen G. White, 48.

${ }^{91}$ E. G. White, Early Writings, 87. For the original, see idem, Supplement to the Christian Experience and Views of Ellen G. White (Rochester, NY: James White, 1854), 
After reviewing Ellen White's early views of the 144,000 who are sealed before the close of probation, and who are prepared to endure the time of trouble, we can now summarize. White as a teenager had had a conviction of her lack of holiness with which to meet Jesus when He returned. In her 1844 vision of the 144,000, she again posed the question of the need for purity on the part of those who were to meet their returning Lord. After the Sabbath conferences of 1848, she began to proclaim the reality of the saints' needing to live in God's sight without a high priest in the heavenly sanctuary, and began to emphasize the need for purity of heart. Then, in 1851 and after, there is seen a decided stress on the need for preparation for the latter rain, the sealing, and the time of trouble. This preparation includes a confession of sin, purification by suffering and obedience to the truth, reflecting the image of Jesus fully, overcoming every sin, and a deep, living experience. Satan is intent on preventing this and the consequent sealing of the believers, since after that he knows they will be beyond his power.

\section{The Great Controversy Vision, 1858}

It was in 1858 that Ellen White had her first comprehensive vision of the cosmic controversy between Christ and Satan, a struggle, begun in heaven, that had continued throughout earth's history. ${ }^{92}$ In 1860 , she stated that in this vision "most of the matter of the Great Controversy which I had seen ten years before, was repeated. ${ }^{\prime 93}$ However, now

$5-6$.

${ }^{92}$ A. L. White, Ellen G. White, 1:366.

${ }^{93}$ Ellen G. White, Spiritual Gifts: My Christian Experience, Views and Labors in Connection with the Rise and Progress of the Third Angel's Message (Battle Creek, MI: James White, 1860; reprint, Washington, DC: Review and Herald, 1945, as volume 2 of 
she was told to write out what she had seen. The result was a 219-page book entitled The Great Controversy, between Christ and His Angels, and Satan and His Angels, now included as the third section of Early Writings. ${ }^{94}$ Here is given the sweep of the history of Satan's fall from heaven, his temptation of the human race to rebel against God, and the plan of salvation. The portrayal centers its attention on the Fall, the life of Christ, and the events at the close of time, though the treatment of these is brief compared to what we see in her subsequent writings. As an example, the word "law" is not used at all in the chapters on the fall of Satan and the fall of man. Though her later writings exhibit an expanded description of last-day events, and even in this first comprehensive sweep of the great controversy the detail in which closing events are described is less than the total of what she had written up to this point, we do see some of the main elements that were observed in her earlier writings.

White repeats here the description of the faces of the believers lighting up at the voice of God just prior to the appearing of Christ, as well as in connection with the loud cry before the close of probation, which prepares the saints "to endure the hour of temptation." ${ }^{95}$ She uses similar expressions to describe the faces of those who gave the Ellen G. White, Spiritual Gifts: Volumes One and Two), 270.

${ }^{94}$ Ellen G. White, Spiritual Gifts, vol. 1, The Great Controversy, between Christ and His Angels, and Satan and His Angels (Battle Creek, MI: James White, 1858; reprint, as component of Early Writings, Washington, DC: Review and Herald, 1945).

${ }^{95}$ E. G. White, Early Writings, 278-279, 285. In 1857, the loud cry was clearly linked to the refreshing and the latter rain: "An angel answered, 'It is the latter rain. The refreshing from the presence of the Lord. The loud cry of the Third Angel.' Idem, "The Future," Advent Review and Sabbath Herald, December 31, 1857, 59. 
first angel's message and the face of Stephen at his trial. ${ }^{96}$

We again see the clear demarcation between conditions before and after the close of probation, marked by the departure of Christ from the heavenly sanctuary. For the first time, we see the word "atonement" used by Ellen White: "While Jesus had been ministering in the sanctuary, ... [He] had received His kingdom, having made the atonement for His people and blotted out their sins." After this atonement is made and Christ leaves the sanctuary, there is no more intercession for sin.

As Jesus moved out of the most holy place, I heard the tinkling of the bells upon His garment; ... There was then no mediator between guilty man and an offended God.... It was impossible for the plagues to be poured out while Jesus officiated in the sanctuary; but as His work there is finished, and His intercession closes, there is nothing to stay the wrath of God.... In that fearful time, after the close of Jesus' mediation, the saints were living in the sight of a holy God without an intercessor. ${ }^{97}$

White reports seeing the plagues begin to fall and that "now there was no atoning blood to cleanse the guilty." ${ }^{" 98}$ This concept of living through the time of trouble without an intercessor in the heavenly sanctuary, first introduced in a broadside after the 1848 Sabbath conferences, and then developed in her first published work in 1851, is now proclaimed in a fuller, more systematic form. ${ }^{99}$

An interesting aspect of the condition of the saints during this time is highlighted,

${ }^{96}$ E. G. White, Early Writings, 197, 240-241. The original version says of those who accepted the first angel's message: "Their faces lighted up, and beamed with holy joy.” Idem, Spiritual Gifts, 4 vols. (Battle Creek, MI: Steam Press of the Seventh-day Adventist Pub. Association, 1858-1864; reprint, Washington, DC: Review and Herald, 1945), 1:144-145.

${ }^{97}$ E. G. White, Early Writings, 280.

${ }^{98}$ Ibid., 281.

${ }^{99}$ See pp. 33-35, 37-39 below. 
which will be developed in later treatments of the time of trouble. ${ }^{100}$ Though at first the saints "in the hour of trial ... were calm and composed, trusting in God and leaning upon His promise that a way of escape would be made for them," soon she "saw the saints suffering great mental anguish" as the wicked seemed about to destroy them and they appeared to be abandoned by God. ${ }^{101}$ If the saints after being sealed are placed "beyond [Satan's] power," it surely does not mean in the sense of not experiencing fierce temptations, or not being made to suffer by the devil's activity. ${ }^{102}$

\section{Preparing for Translation, 1859-1868}

In the next decade or so, messages from the pen of Ellen White would keep before believers the need for making a speedy and thorough preparation for the climactic events seen to lie in the near future. A recurring theme is the need to be fit for living safely through the time of trouble and for being translated into the society of sinless beings. This is seen to be a step-by-step process, which culminates in the eradication of every character defect. However, the saints going through the time of trouble experience keen anguish, as they feel unworthy, though they are unable to recall any sins they have not

${ }^{100}$ See pp. 56-57, 71-72, 75-76 below.

${ }^{101}$ E. G. White, Early Writings, 283. Mental anguish is also depicted in the struggles of the saints undergoing the shaking, prior to the close of probation: "Their countenances were pale and marked with deep anxiety, expressive of their internal struggle. Firmness and great earnestness was expressed in their countenances; large drops of perspiration fell from their foreheads." Ibid., 269.

${ }^{102}$ E. G. White, “A Vision God Gave Me,” in Manuscript Releases, 8:220. See pp. 43-44 above. 
previously confessed. Their experience is likened to that of Christ and other biblical characters.

\section{Without Blemish}

White spoke clearly to the question of what is involved in the preparation for translation without experiencing death. In 1864 she published an expanded treatment of the Old Testament portion of the "great controversy" story as volume 3 of Spiritual Gifts. Here she presents Enoch as a representative of last-day saints, who also are "fitting for translation to Heaven" by seeking "purity of thought, and holy conformity to [God's] will, until his divine image [is] reflected in them." ${ }^{103}$ Likewise, in the Jan. 19 issue of the Advent Review and Sabbath Herald, she pointed out that God had been leading out a people, and that "He will purify them, he will cleanse them, and fit them for translation." ${ }^{104}$

In An Appeal to Mothers, White pleaded with believers to "ever realize that they are fitting for immortality, and that if saved, they must be without spot, or wrinkle, or any such thing." To live with sinless beings, "their Christian character must be without a blemish." ${ }^{105}$ In an 1868 testimony she stated that preparing for translation includes overcoming "every defect in the moral character," and "all the unlovely, unlovable traits

${ }^{103}$ E. G. White, Spiritual Gifts, 3:59.

${ }^{104}$ Ellen G. White, "Communications to Elder M. Hull," Advent Review and Sabbath Herald, January 19, 1864, 62. This was also published in pamphlet form that year as Testimony Number 10. Idem, Testimonies, 1:431.

${ }^{105}$ Ellen G. White, An Appeal to Mothers (Battle Creek, MI: Seventh-day Adventist Pub. Association, 1864), 29. 
of character." "None will be translated to heaven while their hearts are filled with the rubbish of earth."106

Whether there is a special level of overcoming expected of those who are translated is not directly addressed in these passages, and may very well have not been a concern to the author. But one reason that an end-time people might be required to exhibit a higher degree of overcoming is found in her discussion of Moses' experience on the way to lead his people out of Egypt. He had neglected to circumcise his youngest son in deference to his wife. When in consequence an angel threatened to destroy him, he promptly carried out the neglected duty. His neglect to carry out one of God's commands would have made it impossible for angels to have provided the necessary protection on his dangerous mission to Pharaoh. Just so, those neglecting to obey God will face the time of trouble without needed angel protection:

In the time of trouble, just previous to the coming of Christ, the lives of the righteous will be preserved through the ministration of holy angels. Those who come up to that trying time, neglecting to obey God's commands, will have no security of their lives. Angels cannot protect them from the wrath of their enemies while they are living in neglect of any known duty, or express command of Jehovah. ${ }^{107}$

Not only is there an urgency to use the last remaining moments of probation to get ready for this time of trouble, ${ }^{108}$ but again we see White's reprimand of those who sit idly

${ }^{106}$ E. G. White, Testimonies, 1:705.

${ }^{107}$ E. G. White, Spiritual Gifts, 3:195-196. Cf. idem, Patriarchs and Prophets, 256. Also, cf. an earlier statement to the effect that "the destroying angel" will "cut down ... unruly children who manifest passion" in the time of trouble. Idem, "Duty of Parents to Their Children," 45.

${ }^{108}$ E. G. White, Spiritual Gifts, 3:135-136; idem, An Appeal to Mothers, 33-34. See also MS 3, 1861: "The uncultivated have spots and wrinkles upon them now. They had better lose no time in commencing the work of cleansing themselves." Idem, Our 
by, expecting the latter rain to do the work of preparation for them. ${ }^{109}$ White declares that believers are unprepared for the latter rain itself, and that this is the reason for the Laodicean message — to fit believers "for the loud cry of the third angel." 110

Health reform is seen as another key component of the work of preparing for the latter rain and translation. In a testimony entitled "The Health Reform," published in 1867, White pointed out that "lustful appetite," "gluttony," and ruling "lower propensities" were interfering with believers being "fitted for translation," and that they were "not prepared for the loud cry."111 In her 1864 commentary on Old Testament history in the setting of the great controversy, White drew a parallel between the rebellion of the followers of Korah and the obstinacy of Adventists who balked at giving up "tea, coffee, snuff and tobacco" in the process of "cleansing themselves, as God has commanded, from all filthiness of the flesh, and of the spirit." ${ }^{112}$ Indeed, in an 1867 testimony regarding the new Adventist health institute, she emphasized that "the great object to be attained through this channel is not only health, but perfection, and the spirit of holiness." 113

High Calling: The Morning Watch Texts with Appropriate Selections (Washington, DC: Review and Herald, 1961), 230.

${ }^{109}$ E. G. White, Testimonies, 1:619.

${ }^{110}$ Ibid., 1:186.

${ }^{111}$ Ibid., 1:486.

${ }^{112}$ E. G. White, Spiritual Gifts, 4a:36-37.

${ }^{113}$ E. G. White, Testimonies, 1:554. 


\section{A Goal-Driven Process}

The writings of Ellen White during this period stress that this preparation for translation is a step-by-step process, with a definite goal in sight. It is clear that the goal is not only attainable, but that failure is not an option. As to the incremental nature of the “fitting" process, we may observe White's declaration in an 1862 testimony that Christ was leading "His people on step by step, purifying and fitting them for translation." "In an 1861 testimony she pointed to refined taste, sanctified judgment, and comely manners as necessary qualitites for those preparing for translation. "The truth is designed to elevate the receiver, to refine his taste and sanctify his judgment. There should be a continual effort to imitate the society we expect soon to join; namely, angels of God who have never fallen by sin. The character should be holy, the manners comely, the words without guile, and thus should we follow on step by step until we are fitted for translation." $" 115$

Another way of looking at this purifying process is as an approach to Christlikeness. In an 1862 testimony, White notes that just as Christ "was strengthened for his last dreadful sufferings" by the glory He received at His transfiguration, so as believers "approach the period of their last conflict, 'the time of Jacob's trouble,' they will grow up into Christ, and will partake largely of his Spirit." The glory of which they will partake "is the latter rain which revives and strengthens them to pass through the time of trouble. Their faces will shine with the glory of that light which attends the third

\footnotetext{
${ }^{114}$ Ibid., 1:133.

${ }^{115}$ Ibid., 1:216.
} 
angel." ${ }^{116}$ On the previous page, White declares that believers "will become more and more like Christ, and thus they will be transformed and fitted for translation." ${ }^{117}$ The same year she wrote that "God is proving and purifying His people. He will refine them as gold until His image is reflected in them and the dross consumed." 118 Again, she writes of a perfect reflection of Christ's image as the criterion of perfection and readiness for translation: "Jesus sits as a refiner and purifier of His people; and when His image is perfectly reflected in them, they are perfect and holy, and prepared for translation." 119

It is quite interesting that prior to this last statement is found what appears to be a contradiction to the idea of perfection as an attainable goal: "As long as Satan reigns we shall have self to subdue, besetments to overcome, and there is no stopping place, there is no point to which we can come and say we have fully attained." ${ }^{120}$ However, it would seem to be against the author's intention to interpret this as meaning that perfection- - the perfect reflection of Christ's image - is unattainable. The context of these statements is a warning against false ideas of instantaneous sanctification. White's emphasis is on the need for continued striving against sin and pleading with God for help; as she said, "there is no stopping place" - contrary to what some were teaching and practicing. It would

${ }^{116}$ Ibid., 1:353.

${ }^{117}$ Ibid.

${ }^{118}$ Ibid., 1:355. For the original, see Ellen G. White, "Regarding the Civil War," MS 5, 1862, published, in part, under the title "The Civil War" in Manuscript Releases: From the Files of the Letters and Manuscripts Written by Ellen G. White, 21 vols. (Silver Spring, MD: E. G. White Estate, 1981-1993), 7:111.

${ }^{119}$ E. G. White, Testimonies, 1:340.

${ }^{120}$ Ibid. 
seem to be reasonable to assume that this striving and pleading would not stop merely because a perfect reflection of Christ's image had been achieved, since these aspects of striving and pleading, including having "self to subdue" and possibly even "besetments to overcome," were characteristic of Christ's life on earth. As White herself says a few sentences earlier, "Jesus, considered as a man, was perfect, yet He grew in grace. ... Even the most perfect Christian may increase continually in the knowledge and love of God."121 Here again we see her argument against a false sanctification. Even Christ, while living on earth, did not lay off His armor, as having already attained.

In 1864 White linked the incarnation of Christ with the efforts of believers who are preparing for translation. In her first published writing on the major health reform vision of $1863,{ }^{122}$ a long chapter in the fourth volume of Spiritual Gifts entitled simply "Health," she addresses the purpose of Christ's taking human nature. Here she likens believers in the end-time to Noah, who was preserved in the ark miraculously after he "had done all that God required of him in making the ark secure." So "after man has done all in his power to insure health, ... he is saved alone by a miracle of God's mercy, as was the ark upon the stormy billows."123 The miracle White here refers to seems to be the incarnation of Christ, with the resulting atonement provided:

Our Redeemer, laying aside his glory and majesty, to take human nature, and to die man's sacrifice, was a miracle of God. It was God's wise arrangement to save fallen man. . . . Jesus has stooped very low in order to reach man in his low estate. And God requires of man to make earnest efforts, and deny self, that he may preserve

\footnotetext{
${ }^{121}$ Ibid., 1:339-340.

${ }^{122}$ E. G. White, Ellen G. White, 2:22.

${ }^{123}$ E. G. White, Spiritual Gifts, 4a:148-149.
} 
his vigor of mind, and elevate himself, and imitate the example of him in whom was no guile. Then will he be benefited with the atonement of Christ. As the Lord bade faithful Noah before the flood, Come thou, and all thy house, into the ark, he will, previous to the time of trouble, say to his faithful saints, who have been preparing for translation, "Come, my people, enter thou into thy chambers, and shut thy doors about thee. Hide thyself as it were for a little moment, until the indignation be overpast. For, behold, the Lord cometh out of his place to punish the inhabitants of the earth for their iniquity. The earth, also, shall disclose her blood, and shall no more cover her slain" [Isa 26:20-21].

Christ took not on him the nature of angels, but the nature of man, that he might acquaint himself with the temptations with which he was beset, and help man in his fallen state, and by his own humiliation and death elevate men to become heirs with him to his Father's kingdom. Christ endured the strongest temptations of Satan, that he might experience in himself the severest conflict which the children of men would have with the fallen foe, and that he might sustain those who should come to him for strength in their temptations. ${ }^{124}$

Like Noah, those preparing for translation by making earnest efforts "are benefited with the atonement." From the context of this statement, being "benefted by the atonement" may be taken to include not only the benefit of Christ's substitutionary death, but also His experience in dealing with the same temptations they find themselves beset with. In this way they can be seen to be preserved miraculously by the power of divine grace through the time of trouble. Again, White's emphasis seems to be on the importance of striving - that God's miraculous power does not come to those who make no efforts on their own behalf, but that this power is more than sufficient for any human need.

Included in the idea of the step-by-step process of purification for translation is the concept of testing. In a number of places, Ellen White points to a proving, testing process that comes ever closer. In connection with an 1859 testimony on the Laodicean message she wrote:

God leads His people on, step by step. He brings them up to different points

${ }^{124}$ Ibid., 4a:149-150. Emphasis supplied. 
calculated to manifest what is in the heart. Some endure at one point, but fall off at the next. At every advanced point the heart is tested and tried a little closer. . . . Said the angel: 'God will bring His work closer and closer to test and prove every one of His people.' . . . Those who come up to every point, and stand every test, and overcome, be the price what it may, have heeded the counsel of the True Witness, and they will receive the latter rain, and thus be fitted for translation. ${ }^{125}$

Two years later, she wrote: "The truth will be brought to bear closer and closer, and will cut off one idol after another, until God reigns supreme in the hearts of His consecrated people."126 Again, in a testimony in 1867, White warned that "God is testing and proving His people," many of whom "will have close work to overcome their peculiar traits of character and be without spot or wrinkle or any such thing." 127

\section{Continuing Sense of Unworthiness}

In this period we see expanded also the concept of mental anguish on the part of those who undergo the time of trouble. In her comments on the experience of Jacob, White depicts the righteous "just before the coming of the Lord," like Jacob, in "mental anguish," crying to God for deliverance. "The righteous, in their distress, will have a deep sense of their unworthiness, and with many tears will acknowledge their utter unworthiness, and like Jacob will plead the promises of God through Christ, made to just

${ }^{125}$ E. G. White, Testimonies, 1:187. Note also: "The third angel is leading up a people, step by step, higher and higher. At every step they will be tested." Idem, Testimonies, 1:190. "God will test and prove his people. One sacred truth after another will be brought to bear upon their hearts, close and cutting, until their faith will be purified and tried like gold, until all their dross will be purged away, and Jesus will present them unto his Father without spot, or wrinkle, or any such thing." Idem, "An Extract from a Letter Written to a Distant Female Friend," Advent Review and Sabbath Herald, September 16, 1862, 126.

${ }^{126}$ E. G. White, Testimonies, 1:237.

${ }^{127}$ Ibid., 1:533. 
such dependent, helpless, repenting sinners. ${ }^{, 128}$ However closely they have been tested and have attained unto Christlikeness, there is apparently no sense of accomplishment, or feeling of satisfaction, on the part of those assumably prepared for translation. Rather, as they look at their life history "they can see but little good" and "their hopes will almost sink," but they appeal to God day and night "in regard to their past sorrow and humble repentance of their many sins. ${ }^{\prime 29}$

At this point an interesting shift in emphasis is seen. Whereas up to now, the criterion for successfully passing through the time of trouble has been the complete overcoming of every sin and defect, as our view shifts to those actually undergoing the trial, the criterion for endurance also changes. Not character defects, but "concealed wrongs" and "hidden sins" are seen as the cause of failing.

They [the righteous] will feel their unworthiness, but will have no concealed wrongs to reveal. If they had sins, unconfessed and unrepented of, to appear then before them, while tortured with fear and anguish, with a lively sense of all their unworthiness, they would be overwhelmed. Despair would cut off their earnest faith, and they could not have confidence to plead with God, thus earnestly for deliverance, and their precious moments would be spent in confessing hidden sins, and bewailing their hopeless condition. ${ }^{130}$

Apparently also critical to preparing for translation, or passing successfully through the time of trouble, is the work of bringing to mind for repentance and confession, sins previously unknown. In any case, what the righteous plead is not that they have overcome these things, but they have confessed them and repented of them.

${ }^{128}$ E. G. White, Spiritual Gifts, 3:132.

${ }^{129}$ Ibid., 3:133, 135.

${ }^{130}$ Ibid., 3:134. 


\section{Delivered by the Voice of God}

In Ellen White's view the pleading of the righteous prevails despite the fact that after Christ leaves the sanctuary, "there will be no atoning blood to cleanse from sin and pollution." Thus we see another evidence that intense mental anguish and striving against temptation is not an indication of sin that needs to be repented of, but simply human weakness, arising partly from a failed history. The lack of a Mediator above will impact negatively, though, on "those professed believers who come up to the time of trouble unprepared" and who belatedly confess their sins, when there is "no atoning blood to cleanse from sin and pollution." ${ }^{131}$ Although their anguished cries are to no avail, the cries for deliverance of the righteous prevail, and, as we have seen in each portrayal of closing events thus far, the voice of God is heard from heaven, at which the faces of the righteous light up. ${ }^{132}$

\section{Expanded Views of the Great Controversy, 1869-1883}

During the next fifteen years, Ellen White would continue to expand her treatment of the great controversy theme. The portrayal of the biblical history begun in her Spiritual Gifts series (1858-1864) was considerably amplified in The Spirit of Prophecy, a planned four-volume series begun in 1870 , with around 400 pages per volume. A separate book on the life of Paul was issued in 1883. However, the final fourth volume of

${ }^{131}$ Ibid.

${ }^{132}$ Ibid., 3:135; E. G. White, Testimonies, 1:354. It is interesting to note how White, continuing in her 1864 expansion of the great controversy story, as seen in Old Testament history, connects David's exultant joy when bringing the ark home to Jerusalem, with the greater "holy joy that all the saints will experience at the voice of God when their captivity is turned." Idem, Spiritual Gifts, 4a:112-113. 
The Spirit of Prophecy, which developed the history after New Testament times, and focused attention on events at the end of the world, was not published until 1884. Up until then, the relatively brief unfolding of the closing scenes of the great controversy, first published in 1858 as the first volume of Spiritual Gifts, had not been officially amplified. In this section we will look at a few themes that were treated in this period of development of the great controversy theme.

\section{Character Perfection a Universal Requirement}

Ellen White had clearly pointed out the necessity of complete overcoming on the part of those preparing for translation. As time passed, and the Advent believers started to die, she began to speak about the preparation needed by humans hoping to enter heaven, whether by resurrection or translation. Speaking to a gathering of believers in 1869, expecting to see Christ soon, she emphasized that "nothing short of perfection" would enable them "to see the King in his beauty," and that only when sins and iniquity are overcome is one "in a condition to receive the finishing touch of immortality." Warning them against becoming absorbed in worldly interests, she points out that they cannot delay the work of preparation, since when Christ comes, "no atoning blood" will wash away their stains. But she makes no difference between the character perfection needed for dying and that required for translation. "Just as you fall, so you must come up in the resurrection. And if you are living when the Son of Man is revealed, just as you are then found ... so you must remain. The impure cannot then obtain perfection of 
Christian character. No work of purification can then be performed." ${ }^{\prime 33}$ Similarly, based on a vision she received on October 2, 1868, she wrote in an 1870 "Appeal to the Church" that "one spot, one wrinkle, one defect in the character, will forever debar [the professed people of God] from heaven," but that God desires them to "perfect holiness ... and be prepared to die in the Lord or to be translated to heaven." ${ }^{\prime 134}$ An indication that White's exhortation is not simply for believers to cover both contingencies by developing a perfect character is found in counsel given to an Adventist member in 1875: "Sickness and disease came upon you when you were unprepared to die, for you had not perfected a Christian character and had not a moral fitness for heaven.... Your probation has been lengthened that you may have an opportunity to ... overcome the defects in your character. ${ }^{\prime 135}$

\section{Needed Preparation for Translation}

Though White maintained a need for character perfection regardless of whether one eventually died or was translated, she continued to point out, as she did in a testimony read to workers at Battle Creek in 1881, that God was "leading out a people and preparing them for translation." ${ }^{.136}$ Such preparation extended to choosing a diet. An 1869 testimony on "Moral Pollution" identified meat and food prepared with grease as

${ }^{133}$ Ellen G. White, "Practical Remarks," Advent Review and Sabbath Herald, April $12,1870,130$.

${ }^{134}$ E. G. White, Testimonies, 2:452-453.

${ }^{135}$ Ibid., 4:215-216.

${ }^{136}$ Ibid., 5:30. 
undesirable items on the tables of those claiming "to be preparing for translation to heaven. The less feverish the diet, the more easily can the passions be controlled." 137 Even habits of orderliness are to be maintained. In an 1871 testimony to a minister who was lacking in this area, she stated: "The nearer mortals attain to the order and arrangement of heaven, the nearer are they brought to that acceptable state before God which will make them subjects of the heavenly kingdom and give them that fitness for translation from earth to heaven which Enoch possessed preparatory to his translation." "138

Two years before her expanded treatment of last-day events in volume four of The Spirit of Prophecy, Ellen White in 1882 gave a rather detailed account of the importance of preparing for the end, in a testimony entitled "The Seal of God." Here she emphasized, as in earlier writings, the fact that there will be a period of time after Christ leaves the sanctuary in heaven and before He returns to earth, when the seven last plagues are poured out. During this time "no atoning blood will ... wash away the stains of sin." White reminds her readers that "all who receive the seal must be without spot before God," and that when this "stamp is impressed, their character will remain pure and spotless for eternity."139 Preparation for this sealing involves also a preparation for the latter rain, which, as we have seen, also prepares believers to stand during the time of

${ }^{137}$ Ibid., 2:352.

${ }^{138}$ Ibid., 2:698.

${ }^{139}$ Ibid., 2:212, 216. Again, we may have a question as to how it is that the sealed ones remain spotless through the time of testing they have yet to undergo during the severe time of Jacob's trouble; in any case, there is no intercessor should they stumble. See pp. 43-44 and 47-48 above. 
trouble and to be translated. ${ }^{140}$ Both require a thorough cleansing of the "soul temple," terminology White began using in the 1870s: "Not one of us will ever receive the seal of God while our characters have one spot or stain upon them. It is left with us to remedy the defects in our characters, to cleanse the soul temple of every defilement. Then the latter rain will fall upon us as the early rain fell upon the disciples on the Day of Pentecost." $" 141$

\section{The Time and Extent of the Purifying Process}

This cleansing of the soul temple takes place on a daily basis, according to White's first use of the symbol in her discussion of Christ's cleansing of the earthly temple: "In the defilement and cleansing of the temple we have a lesson for this time.... It is necessary that Jesus should occupy his temple in the human heart every day, and cleanse it from the defilement of $\operatorname{sin.}{ }^{" 142}$ It is not clear how much this soul-cleansing has to do with an end-time purification process. But she freely speaks of a lifelong process of character perfection, in which the grain matures and is finally ready for the harvest. In her first discussion of the parable of the seed that matures to harvest, she speaks of growth toward "the perfection of righteousness" as a "day by day" process that culminates

${ }^{140}$ See pp. 38-39, 52-53 above.

${ }^{141}$ E. G. White, Testimonies, 5:214. White referred to the cleansing of the soul temple frequently in following years. The first such use appears to be in 1877, while writing on the life of Christ, drawing lessons from Christ's cleansing of the earthly sanctuary. Idem, Spirit of Prophecy, 2:123-124.

${ }^{142}$ E. G. White, Spirit of Prophecy, 2:123-124. 
when "the soul is ripe for the harvest, the life-work is ended."143

However, those living at the end of time obviously face a quickened pace of overcoming, as their time of probation necessarily ends at an earlier age than most. At a minimum, there is an urgency placed on end-time believers because of the need to develop spotless, Christlike characters before probation closes. In 1869, writing to a "Brother P" who struggled to gain control of a rash temper, White pointed out that God was shaping him to be a part of His temple, but that "not a blow is to be struck after probation closes. You must now, in the hours of probation, overcome your impetuous temper, or be separated from God at last." ${ }^{, 14}$ Here we see what White included among the character defects to be overcome prior to translation.

About the same time, she wrote in a letter to a couple whose children had developed habits of "self-abuse" that "the animal propensities are strengthened and bear sway, while the moral and intellectual powers are weakened and become servants to the baser passions" when parents provide a rich diet for their children. "It is impossible for those who indulge the appetite to attain to Christian perfection." ${ }^{145}$ Here again we see that "animal propensities" and "baser passions" are among those traits to be cleansed from the characters of those preparing for the Advent. In another indication of the practical nature of the moral cleansing she envisioned, White in an 1872 testimony

${ }^{143}$ Ibid., 2:244. On the lifelong work of stain removal, and even the eternity-long advancement along the lines of conformity to God's will, see also E. G. White, Testimonies, 4:429; idem, "The True Vine," Advent Review and Sabbath Herald, September 20, 1881, 193 (1).

${ }^{144}$ E. G. White, Testimonies, 2:430-431.

${ }^{145}$ Ibid., 2:400. 
emphasized again the importance of the Health Institute at Battle Creek, stressing its importance as "one of the greatest aids in preparing a people to be perfect before God. In order to attain to this perfection, men and women must ... be brought into a position where they will discern the imperfections in their moral characters." ${ }^{.146}$

Probably the strongest statements by Ellen White during this period in relation to the extent of the purifying process are those that seem to point to a reclamation of some of the qualities of pre-Fall existence. In an 1881 Review article on the law, she asserts that "obedience to its requirements will perfect Christian character, and restore man, through Christ, to his condition before the fall." ${ }^{\prime 17}$ And a few months later, in concluding an appeal written for the 1882 camp meetings, White maintains that Christ took human nature for the purpose of leaving a perfect pattern, with the intention that "our fallen nature" might be "purified": “Jesus took upon Himself man's nature, that He might leave a pattern for humanity, complete, perfect. He proposes to make us like Himself, true in every purpose, feeling, and thought—true in heart, soul, and life. This is Christianity. Our fallen nature must be purified, ennobled, consecrated by obedience to the truth."148 It is not necessary to understand such references to the restoration of certain aspects of the pre-Fall condition, or to the purification of fallen nature, as implying the

${ }^{146}$ Ibid., 3:166.

${ }^{147}$ Ellen G. White, "The Exalted Position of the Law of God," Advent Review and Sabbath Herald, September 27, 1881, 210 (2).

${ }^{148}$ E. G. White, Testimonies, 5:235. 
acquisition of sinless nature prior to glorification. ${ }^{149}$ In other places White clearly denies this. ${ }^{150}$ White does, however, clearly stress that any change that occurs in human character must happen prior to the point of glorification. In her "Practical Remarks," spoken at a gathering of Adventists in 1869, she appealed to believers to take Enoch's example seriously as an example of what is possible for end-time believers. They must have perfect, spotless characters when Christ comes, just as Enoch lived an "unsullied" life, though surrounded by evil. And ample provision has been made in the incarnation of Christ and the ministry of angels to assist humans in their trials and temptations:

Angels of God are weighing moral worth; and we are to obtain a fitness here to join the society of sinless angels. Do you expect that when Christ comes he will give you that fitness? Not at all. You must be found of him without spot, without blemish, or wrinkle, or anything like it. Now is the watching and trying time. Now it is the time to obtain a preparation to abide the day of his coming, and to stand when he appeareth. Do you say that you cannot do it because around you are so much sin and iniquity and corruption? I refer you to Enoch....

Enoch represents those who shall remain upon the earth and be translated to Heaven without seeing death. He represents that company that are to live amid the perils of the last days, and withstand all the corruption, vileness, sin, and iniquity, and yet be unsullied by it all. We can stand as did Enoch. There has been provision made for us. Help has been laid upon One that is mighty; and we all can take hold upon his mighty strength. Angels of God, that excel in strength, are sent to minister to those who shall be heirs of salvation....

Help has been laid upon One who is mighty. The great burden-bearer, who took our nature that he might understand how to sympathize with our frailty, and with our temptations, knows how to succor those that are tempted. ${ }^{151}$

Thus White seems to maximize the potential for character change prior to the coming of

\footnotetext{
${ }^{149}$ For further discussion of the question of a restoration of aspects of the pre-Fall condition, see pp. 230-234 below.

${ }^{150} \mathrm{Cf}$. Ellen G. White, “'Abide in Me,"” Signs of the Times, March 23, 1888, 178 (2). This is quoted on pp. 78-79 below.

${ }^{151}$ Ellen G. White, "Practical Remarks (Concluded)," Advent Review and Sabbath Herald, April 19, 1870, 138-139.
} 
Christ, while denying character change at the point of His coming.

However, in the 1880 edition of Life Sketches of James and Ellen White,

Ellen White warned those who felt they had attained to perfection that "no matter how bold and earnest one may be in his claims of spiritual soundness, and perfection of character, if he lacks Christian grace and humility, the dregs of the disease of sin is in his nature, and, unless it is purged from him, he cannot enter the kingdom of heaven." ${ }^{152}$ Similarly, in 1881, in the first of a series of Review articles on sanctification, she pointed out that the nearer believers approach to the image of Christ, "the more clearly will they discern its spotless perfection, and the more deeply will they feel their own defects."153 Thus, rather than feeling like overcomers, those who most closely resemble Christ will feel the most unworthy, according to White.

\section{A Final Work of Vindication}

One further aspect of White's expanded treatment of the great controversy in the period of the 1870 s and early 1880 s is seen in the introduction of language that points to an end-time vindication of God's honor. In writing on the great controversy theme, White often points to the cross as the pivotal event in the controversy. Christ is depicted as having given His life as a sacrifice for the purpose of saving sinners while at the same

${ }^{152}$ James White and Ellen G. White, Life Sketches: Ancestry, Early Life, Christian Experience, and Extensive Labors of Elder James White, and His Wife Mrs. Ellen G. White (Battle Creek, MI: Seventh-day Adventist Pub. Association, 1880), 211-212. $18,1881,33$

${ }^{153}$ Ellen G. White, "Sanctification," Advent Review and Sabbath Herald, January 
time vindicating God's law, and thereby proving its immutability. ${ }^{154}$ However, she was quick to point out the folly of those who reasoned from this that any further attempt to obey the law would bring them into bondage again. In an 1878 article in Signs of the Times, she reports on a rather intense discussion she had with ministers of other faiths while on board a boat bound for Oregon from California. When she overheard their accusations of legalism, she strongly defended the Adventist position:

Christ did not come to excuse sin, nor to justify a sinner while he continued to transgress that law for which the Son of God was to give his life to vindicate and exalt. ... .

It is folly to bid the sinner come to Christ before being convicted of his sin by being brought before the mirror of the law of God. What is the sinner to be converted from? The transgression of God's law to obedience of it. But if he is told that he cannot keep the law of God, and that if he should attempt it he would be brought into bondage, to what is he then converted,--transgression of the law to a continuance in that transgression? This is absurd. ${ }^{155}$

We can see clearly here White's high view of the law, which she shared with Seventh-day Adventists in general. They felt it was their mission to exalt and honor God and His law in the end-time climax of the great controversy over the claims of God. Any argument that obedience was not possible was seen as an affront to Christ and His mission to save sinners.

Ellen White saw Adventists as called, like the Jews in the time of Nehemiah, to "preserve the honor of the cause of God and to vindicate His truth." ${ }^{156}$ Writing of the

${ }^{154}$ See, for example, Ellen G. White, "Redemption - No. 1," Advent Review and Sabbath Herald, February 24, 1874, 83.

${ }^{155}$ Ellen G. White, "Incidents on the Voyage to the North Pacific," Signs of the Times, July 18, 1878, 212.

${ }^{156}$ E. G. White, Testimonies, 3:574. 
growth of the publishing work in 1881, she depicts the early work in the context of the great controversy: "The believers, though few in number, were earnest and zealous to vindicate the honor of God in exalting His law which had been made void, and to press back the workings of Satan revealed in every form of destructive error." ${ }^{157}$

Especially at the very close of time, White portrays a necessary vindication of God's honor. In her 1882 testimony on the "Seal of God," she points out that God will "interfere and vindicate His own honor" when humans exceed the limits He has placed. ${ }^{158}$ But this does not preclude the utilization of loyal followers in His work of upholding the divine law. Writing to a young ministering couple in 1873 , White noted that "in the final victory" God would make use of "those who stand like faithful soldiers to battle against wrong, and to vindicate the right, warring against principalities and powers, against the rulers of the darkness of this world, against spiritual wickedness in high places." ${ }^{159}$

In connection with an end-time vindication of God's honor, we might also note White's reference to the climax of the work of Christ as realized in the end-time church. Toward the end of her chapter on "The Ascension of Christ" in the third volume of The Spirit of Prophecy, White declares that "the church, in [Christ's] name, is to carry to glorious perfection the work which he has commenced." 160 The focus of Ellen White on

${ }^{157}$ Ibid., 4:593.

${ }^{158}$ Ibid., 4:208.

${ }^{159}$ Ibid., 3:327.

${ }^{160}$ E. G. White, Spirit of Prophecy, 3:260-261. It is interesting to note that only a few sentences earlier, she inserts a definition of the work that Christ accomplished on earth: "He prayed: 'I have finished the work which thou gavest me to do. [That is, he had wrought out a righteous character on earth as an example for men to follow.]"' The 
the role of last-day believers in the context of the great controversy can thus be seen in this period.

Developed Portrayal of the Time of Trouble, 1884-1888

When the fourth volume of The Spirit of Prophecy was published in 1884, with its amplified narration of closing events, it had been twenty-six years since the great controversy story had first been published in brief, but comprehensive, fashion in the first volume of Spiritual Gifts. If one compares the treatment of the time of trouble in these two volumes, along with The Great Controversy, White's final and most complete rendering of closing events on earth, one can easily see the massive expansion that took place in the 1884 version. What was covered in two chapters totaling eight small pages in 1858 was lengthened to a chapter of twenty-one larger pages in 1884 . This was modestly expanded to twenty-two even larger pages in 1888. By approximate word count, there was a 200 percent increase from 1858 to 1884 , and a 30 percent increase from 1884 to $1888 .{ }^{161}$ As would be expected, though White's general outline of last-day events is quite stable, there is a marked development along certain lines. This section will first examine new insights from first the amplified version of the time of trouble (and a few relevant selections from other chapters) given in the 1884 Spirit of Prophecy account, followed by other writings from the period

connection between Christ's work of character development and the church's perfection that seems to be implied here is made explicit in later writings. See pp. 142-144, below.

${ }^{161}$ E. G. White, Spiritual Gifts, 1:197-204; idem, Spirit of Prophecy, 4:431-451; idem, Great Controversy, 613-634. This is the 1911 edition of The Great Controversy, in which this chapter on the time of trouble is virtually unchanged from the 1888 edition. 
1884-1888, and then additional points from the 1888 Great Controversy version of closing events.

\section{Spirit of Prophecy, Volume 4, 1884}

Chapter 34 of volume 4 of The Spirit of Prophecy, "The Time of Trouble," opens very similarly to chapter 35 of volume 1 of Spiritual Gifts, "The Third Message Closed." God's people have received the latter rain and the seal of God, their sins have been blotted out, "the atonement" has been made for them by Christ, and they are prepared for the trial ahead. When Christ leaves the sanctuary "the righteous must live in the sight of a holy God without an intercessor. ${ }^{" 162}$ But the call to prepare is now more direct and urgent. Emphasizing the unimaginable severity of the trial, White warns that "we shall need an experience which we do not now possess, and which many are too indolent to obtain.... Now, while the precious Saviour is making an atonement for us, we should seek to become perfect in Christ." ${ }^{\text {"163 }}$ Besides this frequently seen call for perfection, White incorporates into her discussion of the time of Jacob's trouble the need for confession of all sins prior to this time: "If the people of God had unconfessed sins to appear before them while tortured with fear and anguish, they would be overwhelmed... All who endeavor to excuse or conceal their sins, and permit them to remain upon the

${ }^{162}$ E. G. White, Spirit of Prophecy, 4:432; idem, Great Controversy, 613-614. (References to vol. 4 of The Spirit of Prophecy will be accompanied by references to parallel portions of The Great Controversy for convenience. The wording of direct quotes is the same in both sources, except where noted.) Cf. idem, Spiritual Gifts, 1:198199.

${ }^{163}$ E. G. White, Spirit of Prophecy, 4:440; idem, Great Controversy, 623. The Great Controversy's wording of the last sentence is: "Now, while our great High Priest is making the atonement for us, we should seek to become perfect in Christ." 
books of Heaven, unconfessed and unforgiven, will be overcome by Satan." "164 Thus two areas of preparation for the time of trouble continue to be identified: perfection of character and confession of all sin.

White gives more detail regarding the deep feelings of unworthiness on the part of those undergoing the trial, in connection with relating Jacob's experience. As they see the manifestation of rebellion all around, and realize how little power they have to "urge back the mighty tide," they experience "a throb of self-reproach," or, as worded in The Great Controversy, "a keen sense of self-reproach. . . . They feel that had they always employed all their ability in the service of Christ, going forward from strength to strength, Satan's forces would have less power to prevail against them."165 They suffer "the keenest anxiety, terror, and distress" as they are "placed in the furnace of fire; their earthliness must be consumed, that the image of Christ may be perfectly reflected."166

As she moves through the chapter, White continues to point out the anguish this group undergoes. And in a new way, she identifies this group's experience with that of Christ. In connection with the jeering of the wicked as the righteous seem abandoned to destruction, she writes that "the waiting ones remember Jesus dying upon Calvary's cross" and the taunts cast at Him. "Their countenances express their internal struggle. Paleness sits upon every face." Angels are not allowed to deliver the sufferers, as this

${ }^{164}$ E. G. White, Spirit of Prophecy, 4:437-438; idem, Great Controversy, 620. She had earlier expressed this in connection with her comments on Jacob's wrestling with the Angel. Idem, Spiritual Gifts, 3:134; idem, Spirit of Prophecy, 1:123. See also p. 57 above.

${ }^{165}$ E. G. White, Spirit of Prophecy, 4:436-437; idem, Great Controversy, 619.

${ }^{166}$ E. G. White, Spirit of Prophecy, 4:437-438; idem, Great Controversy, 620-621. 
experience is necessary: "The very delay, so painful to them, is the best answer to their petitions. As they endeavor to wait trustingly for the Lord to work they are led to exercise faith, hope, and patience, which have been too little exercised during their religious experience." ${ }^{167}$ And they are not left without help. Christ identifies with their experience. They hear His voice:

"I am acquainted with all your sorrows; I have borne your griefs. You are not warring against untried enemies. I have fought the battle in your behalf, and in My name you are more than conquerors."

The precious Saviour will send help just when we need it. The way to heaven is consecrated by His footprints. Every thorn that wounds our feet has wounded His. Every cross that we are called to bear He has borne before us. ${ }^{168}$

The great interest of heaven in the experience that the end-time believers undergo is understood more clearly from White's discussion of the interest of Satan himself in this group of people. In White's portrayal of the investigative judgment, Satan is pictured as accusing Christ's followers before God. He "points to their defective characters, to their unlikeness to Christ which has dishonored their Redeemer." This is revised slightly in The Great Controversy: "He points to the record of their lives, to the defects of character, the unlikeness to Christ, which has dishonored their Redeemer." 169

This attack on God's people is not new, White points out, having existed since God first promised to put enmity between humans and Satan. In the chapter, "Enmity Between Man and Satan" (which follows chapters on the investigative judgment and the origin of evil), White speaks of the efforts of Satan's agents to "build up his kingdom in

${ }^{167}$ E. G. White, Spirit of Prophecy, 4:446-447; idem, Great Controversy, 630-631.

${ }^{168}$ E. G. White, Spirit of Prophecy, 4:449-450; idem, Great Controversy, 633.

${ }^{169}$ E. G. White, Spirit of Prophecy, 4:309-310; idem, Great Controversy, 484. 
opposition to the government of God" and to "allure [Christ's followers] from their allegiance.... As Satan endeavored to cast reproach upon God, so do his agents seek to malign God's people [and] destroy his followers.... Such is the work that will be carried forward in the great controversy between Christ and Satan to the close of time." ${ }^{\prime 170}$ Thus attacks on God's people are closely connected to Satan's charges against God in the cosmic controversy.

White highlights the role of this cosmic battle between good and evil in her depiction of last-day events. After discussing the investigative judgment, attention is turned to the origin of evil and the need for God to be vindicated before the universe, after Satan introduced suspicion in regard to the justice of His rule. When Lucifer "stubbornly justified his course, ... it became necessary for the Lord of Heaven to vindicate his justice and the honor of his throne." ${ }^{\text {171 }}$ The way God does this is made clear, for in the same chapter White asserts that by the death of Christ "God's law stands fully vindicated." ${ }^{172}$

But obviously Satan still has accusations to make. And, according to White, God allows these charges to go to trial. In her discussion of the time of Jacob's trouble, she clearly outlines the cosmic battle transpiring behind the scenes. A comparison is drawn between Esau's attempt to destroy Jacob, who had done wrong, and Satan's end-time attempt to wipe out God's people, who also have sinned. At this point in time, Satan

${ }^{170}$ E. G. White, Spirit of Prophecy, 4:326. Cf. idem, Great Controversy, 507.

${ }^{171}$ E. G. White, Spirit of Prophecy, 4:320. The Great Controversy lacks this sentence, as this chapter is considerably revised. Cf. idem, Great Controversy, 496.

${ }^{172}$ E. G. White, Spirit of Prophecy, 4:323. Cf. idem, Great Controversy, 503. 
"numbers the world as his subjects; but the little company who keep the commandments of God are resisting his supremacy. If he could blot them from the earth, his triumph would be complete." 173 This idea is repeated at the close of the chapter: "If the righteous were now left to fall a prey to their enemies, it would be a triumph for the prince of darkness." 174 This is taken from the 1858 version, which states: "I saw that if the wicked were permitted to slay the saints, Satan and all his evil host, and all who hate God, would be gratified. And O, what a time of triumph it would be for his Satanic majesty, to have power, in the last closing struggle, over those who had so long waited to behold Him whom they loved."175

But in the expanded 1884 version, White clearly delineates Satan's argumentation of his case in the underlying struggle. He presents the sins of God's people "in the most exaggerated light, representing this people to be just as deserving as himself of exclusion from the favor of God. He declares that the Lord cannot in justice forgive their sins and yet destroy him and his angels. He claims them as his prey and demands that they be given into his hands to destroy." At this point God is depicted as permitting the devil to test His people: "As Satan accuses the people of God on account of their sins, the Lord permits him to try them to the uttermost. Their confidence in God, their faith and firmness, will be severely tested." ${ }^{116}$

${ }^{173}$ E. G. White, Spirit of Prophecy, 4:435; idem, Great Controversy, 618.

${ }^{174}$ E. G. White, Spirit of Prophecy, 4:451; idem, Great Controversy, 634.

${ }^{175}$ E. G. White, Spiritual Gifts, 1:204.

${ }^{176}$ E. G. White, Spirit of Prophecy, 4:435-436; idem, Great Controversy, 618. 
The way in which Satan attempts to destroy the believers in this time of testing is indicative: "Satan endeavors to terrify them with the thought that their cases are hopeless. ... He hopes so to destroy their faith that they will yield to his temptations and turn from their allegiance to God." ${ }^{\text {"177 }}$ The controversy thus revolves around questions of allegiance and honor. In the 1858 discussion of the time of trouble, White had not yet issued volume 3 of Spiritual Gifts, in which she elaborated on the significance of the "time of Jacob's trouble," first mentioned in $1846 .{ }^{178}$ The anguish of the saints seems to be merely for their own survival, whereas in the 1884 portrayal, their concern is also for the honor of God. In the 1858 portrayal of the time of trouble, the description of the mental anguish the saints undergo is followed immediately by their cries to God for deliverance, when it appears He has abandoned them to destruction. In the 1884 depiction, a lengthy interpretation of the experience of Jacob is inserted. Here, the saints' struggle is more immediately set in the context of the great controversy:

Though God's people will be surrounded by enemies who are bent upon their destruction, yet the anguish which they suffer is not a dread of persecution for the truth's sake. ... If they could have the assurance of pardon they would not shrink from torture or death; but should they prove unworthy, and lose their lives because of their own defects of character, then God's holy name would be reproached. ${ }^{179}$

Here again is seen the connection between the fate of the end-time believers and the honor of God.

${ }^{177}$ E. G. White, Spirit of Prophecy, 4:436; idem, Great Controversy, 618-619.

${ }^{178}$ See E. G. White, Spiritual Gifts, 1:201-204, 3:128-137; Harmon, To the Little Remnant Scattered Abroad.

${ }^{179}$ E. G. White, Spirit of Prophecy, 4:436; idem, Great Controversy, 619. Cf. idem, Spiritual Gifts, 1:202-203; idem, Spirit of Prophecy, 4:436, 446; idem, Great Controversy, 619, 630. 
It is not until after the millennium that the controversy is finally settled completely. In the last chapter of the 1884 account, White states that "every question of truth and error in the long-standing controversy is made plain. God's justice stands fully vindicated." Yet even at this point the focus of attention is on the cross: "Before the whole world is clearly presented the great sacrifice made by the Father and the Son in man's behalf."'180

From this brief overview of pertinent sections of volume 4 of The Spirit of Prophecy, a rather clear picture emerges of White's pronounced development of the great controversy theme between 1858 and 1884 in connection with the events transpiring after the close of probation.

\section{Other Writings from the Period, 1884-1888}

Between and including the years of publication of the fourth volume of The Spirit of Prophecy in 1884 and The Great Controversy in 1888, other writings of Ellen White shed light on her views of events connected with the close of probation. She pointedly connected preparation for translation with an understanding of Satan's strategy to overthrow Israel at Baal-Peor. In the first of a pair of 1887 Review articles on "The Sin of Licentiousness," White called on believers to shun Satan's temptations on sensuality: "Near the close of this earth's history Satan will work with all his powers in the same manner and with the same temptations wherewith he tempted ancient Israel just before their entering the land of promise.... Those who have not brought the lower passions

${ }^{180} \mathrm{E}$. G. White, Spirit of Prophecy, 4:486. The Great Controversy expands this section, to more completely show the culmination of the cosmic struggle. Idem, Great Controversy, 670-671. 
into subjection to the higher powers of their being, those who have allowed their minds to flow in a channel of carnal indulgence of the baser passions, Satan is determined to destroy with his temptations." "I81 In the conclusion published the following week, White began by pointing out that a people was being "fitted up for translation to heaven." The truth must cleanse them "from all earthliness and sensuality in the most private life. The soul temple must be cleansed. Every secret act is as if we were in the presence of God."182 Similar ideals of moral purity on the part of believers preparing to "meet the approval of God and be without spot or wrinkle" motivated Ellen White in combating fanaticism in 1845 among ex-Millerites. She revealed in an 1885 Review article addressed to "the workers" that there had been "too great familiarity between some men and women" and that "thoughts were running in an impure channel."183

Calls for perfection of character on the part of those preparing for the end continued to come. Addressing the European Council in Basel, Switzerland, in 1885, White, referring to the coming of the latter rain, exhorted believers, "If we are partakers of the divine nature, we shall reflect in life and character the image of our divine Lord. We cannot be indolent in seeking this perfection of character." ${ }^{\prime 184}$ In an 1886 sermon in

${ }^{181}$ Ellen G. White, "The Sin of Licentiousness," Advent Review and Sabbath Herald, May 17, 1887, 305 (1).

${ }^{182}$ Ellen G. White, "The Sin of Licentiousness (Concluded)," Advent Review and Sabbath Herald, May 24, 1887, 321 (1).

${ }^{183}$ Ellen G. White, "An Address to the Workers," Advent Review and Sabbath Herald, November 10, 1885, 689 (1).

${ }^{184}$ Historical Sketches of the Foreign Missions of the Seventh-day Adventists: With Reports of the European Missionary Councils of 1883, 1884, and 1885, and a Narrative by Mrs. E. G. White of Her Visit and Labors in These Missions (Basle: 
Sweden, White reminded readers that Enoch, a representative of the last-day people, lived when "the state of the world was not more favorable for the perfection of Christian character then than it is today." ${ }^{185}$ In 1887 she reminded readers of Signs of the Times of the great need of missionaries, "who will examine themselves daily to see if there is not some defect in their character.... It is only those who are without spot or wrinkle who can stand acquitted before God."186 And in an 1888 Review article on "Individual Accountability" White wrote, "We want to impress upon you the necessity of cleansing yourselves from every stain of sin." ${ }^{, 187}$ It is difficult to miss the sense of urgency and also White's expectation for the believers. Certainly there is no decrease in the intensity of her exhortations compared with those in the early days of her experience.

But along with these urgent admonitions is a warning away from false feelings of sinlessness and holiness. Concluding an 1888 Signs article entitled "“Abide in Me”" White stresses that though "we need to be refined, cleansed from all earthliness, till we reflect the image of our Saviour," "we shall not boast of our holiness.... We cannot say, 'I am sinless,' till this vile body is changed and fashioned like unto His glorious body. But if we constantly seek to follow Jesus, the blessed hope is ours of standing before the

Imprimerie Polyglotte, 1886; reprint, George R. Knight, ed., Historical Sketches of Foreign Missions, with an introduction by George R. Knight, Adventist Classic Library, ed. George R. Knight, Berrien Springs, MI: Andrews University Press, 2005), 136.

${ }^{185}$ Ellen G. White, "The Judgment of the Great Day [sermon at Orebro, Sweden, June 27, 1886]," Signs of the Times, December 29, 1887, 785 (1). $(9-10)$.

${ }^{186}$ Ellen G. White, “Individual Effort,” Signs of the Times, May 19, 1887, 297-298

${ }^{187}$ Ellen G. White, "Individual Accountability," Advent Review and Sabbath Herald, January 31, 1888, 65 (1). 
throne of God without spot or wrinkle, or any such thing; complete in Christ, robed in His righteousness and perfection." ${ }^{\text {188 }}$ Succeeding Signs articles reveal her concern over ministers of other denominations who denied the claims of the law, yet claimed to be above $\sin .^{189}$

An important new development in this period was the attention Ellen White gave to the account in the book of Zechariah $(3: 1-5)$ of the high priest Joshua standing before God in filthy garments, while being accused by Satan. In 1885, White preached on this passage in Europe at least twice, and it is the subject of the last chapter of Testimony Number 32, published also in 1885. 190 "During the time of trouble, the position of God's people will be similar to the position of Joshua," White told her audience in Norway. Just as Joshua's filthy garments were changed, so believers will be clothed in the righteousness of Christ. That White understands this garment to signify an experiential righteousness is evidenced when she continues, "It is through Christ's righteousness alone that we are enabled to keep the law," and asks, "Why will you cling to your miserable defects of character?"191 Thus far there seems little difference with what has been said before.

\footnotetext{
${ }^{188}$ E. G. White, “"Abide in Me,"” 178 (2). This is reprinted in idem, Selected Messages, 3:355.

${ }^{189}$ See Ellen G. White, "Faith and Works," Signs of the Times, March 30, 1888; idem, "Sanctification," Signs of the Times, April 13, 1888.

${ }^{190}$ See Zech 3:1-7; Ellen G. White, "'Is Not This a Brand Plucked out of the Fire?" [sermon at Christiania, Norway, November 14, 1885]," Signs of the Times, June 2, 1890, 321-323 (1-3); Historical Sketches, 154-158; idem, Testimonies, 5:467-476.

${ }^{191}$ E. G. White, “'Is Not This a Brand Plucked out of the Fire?" [sermon at Christiania, Norway, November 14, 1885]," 322 (2).
} 
But deeper insights are gained from the last chapter of Testimony 32, entitled "Joshua and the Angel," in which White draws clear connections between the experience of the end-time saints and the great controversy. She begins by pointing out the need for God's people to understand the behind-the-scenes struggle between Christ and Satan over the human race: "If the veil which separates the visible from the invisible world could be lifted, and the people of God could behold the great controversy that is going on between Christ and holy angels and Satan and his evil hosts concerning the redemption of man, ... they would be better prepared to withstand the devices of Satan." She turns to the story of Joshua and the Angel as "a most forcible and impressive illustration of the work of Satan and the work of Christ, and the power of our Mediator to vanquish the accuser of His people." ${ }^{192}$ She points out that Satan is alarmed that Christ is breaking his hold on his captives. White pictures Satan as criticizing human attempts to obey God: "He is constantly seeking occasion against those who are trying to obey God. Even their best and most acceptable services he seeks to make appear corrupt." ${ }^{, 193}$ Apparently, in White's view, the devil is very interested in questioning the motives and sincerity of God's people.

From this point onward White reiterates much of what she has said elsewhere regarding the end-time trial of the people of God, but often more explicitly. It is interesting to notice that here she places the severe struggle at the time of the sealing, just before the close of probation. Joshua's experience "applies with peculiar force to the

\footnotetext{
${ }^{192}$ E. G. White, Testimonies, 5:467-468.

${ }^{193}$ Ibid., 5:470-471.
} 
experience of God's people in the closing up of the great day of atonement," and not, or not only, to the time of Jacob's trouble. And toward the end of the passage, White states that "while Satan was urging his accusations and seeking to destroy this company, holy angels, unseen, were passing to and from, placing upon them the seal of the living God." ${ }^{194}$

Just as in her discussion of those undergoing the time of Jacob's trouble, here she speaks of Satan's "triumph" being "complete" "if he could blot [the righteous] from the earth." And here also she depicts Satan stating his case against God, but with greater detail:

"Are these," he says, "the people who are to take my place in heaven and the place of the angels who united with me? While they profess to obey the law of God, have they kept its precepts? Have they not been lovers of self more than of God? Have they not placed their own interests above His service? Have they not loved the things of the world? Look at the sins which have marked their lives. Behold their selfishness, their malice, their hatred toward one another."

... "Will God banish me and my angels from His presence, and yet reward those who have been guilty of the same sins? Thou canst not do this, O Lord, in justice. Thy throne will not stand in righteousness and judgment. Justice demands that sentence be pronounced against them." 195

White thus makes clear her understanding of the significance of the spiritual struggle of Christ's end-time followers to the cosmic controversy; she represents Satan questioning the integrity of God's throne in the case that He pardons those whom He has judged worthy of salvation.

White's presentation of the change of raiment of the saints is also instructive in

${ }^{194}$ Ibid., 5:472, 475. Interestingly, the sealing, the change of garment, and the saints rendered "eternally secure from the tempter's devices" coincide in the paragraph on p. 475 .

${ }^{195}$ Ibid., 5:473-474. 
relation to the great controversy theme. In White's understanding "we cannot answer the charges of Satan against us," since only Christ "is able to silence the accuser with arguments founded not upon our merits, but on His own. Yet we should never be content with a sinful life." Two "thoughts" are given that should awaken "greater zeal and earnestness in overcoming evil": (1) "that every defect in character . . . is an open door by which Satan can enter to tempt and destroy; and, furthermore, (2) that every failure and defect on their part gives occasion to the tempter and his agents to reproach Christ." The concern for the honor of God evidenced here mirrors what is seen in the description of the time of trouble in the fourth volume of Spirit of Prophecy. ${ }^{196}$ In this connection, it is interesting to note White's following commentary on the Christcenteredness of the thinking of the saints. She says that "their attention is fixed upon Him, ... and when the command is given" to change their garments, "they are prepared to give Him all the glory of their salvation." 197

As in her Norway sermon, White shows that she understands this change of garment to be experiential: "No sin can be tolerated in those who shall walk with Christ in white. The filthy garments are to be removed, and Christ's robe of righteousness is to be placed upon us. By repentance and faith we are enabled to render obedience." 198

In her commentary on Joshua and the Angel, possibly combining events before and after the close of probation, White again points to a refining process that removes 75 above.

${ }^{196}$ E. G. White, Spirit of Prophecy, 4:436; idem, Great Controversy, 619. See p.

${ }^{197}$ E. G. White, Testimonies, 5:472.

${ }^{198}$ Ibid. See pp. 79 above. 
earthliness, "that the image of Christ may be perfectly reflected." Furthermore, she possibly clarifies here previous statements regarding the restoration of aspects of the preFall nature, showing that it is character that is restored: "The anguish and humiliation of God's people is unmistakable evidence that they are regaining the strength and nobility of character lost in consequence of $\sin .{ }^{1199}$

Ellen White continued in this period to speak often about the vindication of God in connection with the controversy over His law. She is unequivocal in holding up Christ as the ultimate source of this vindication. In 1887 she wrote in the Signs of the Times on the subject of Christ and the law. Maintaining that "the atonement loses its significance when the law of God is rejected," she adds, "The life of Christ was a most perfect and thorough vindication of his Father's law, and his death attested its immutability."200

White also speaks of an ongoing work of vindicating God in the continuing battle with evil, as well as a final vindication at the end. "It becomes every child of God to vindicate His character," affirms an 1885 testimony on the benefits of praising God. ${ }^{201}$ Commenting on Nehemiah's stern dealing with the Jews who married with idolaters, White expresses the "crying need" of people "who will not shrink from vindicating the honor of God." ${ }^{202}$ Speaking to an 1885 camp meeting gathering regarding false

${ }^{199} \mathrm{Ibid} .$, 5:474. Regarding the refining, see pp. 39-40, 52-56, and 62-66. On the restoration of aspects of the pre-Fall condition, see pp. 64-66.

${ }^{200}$ Ellen G. White, "Christ and the Law; or the Relations of the Jew and Gentile to the Law," Signs of the Times, August 25, 1887, 513 (1).

${ }^{201}$ E. G. White, Testimonies, 5:317.

${ }^{202}$ Ellen G. White, "Nehemiah Separates Israel from Idolaters," Signs of the Times, January $24,1884,49$. 
sanctification, that has no respect for the law, White declared that "God will have a people upon the earth who will vindicate his honor by having respect to all of his commandments. ... Not one of us can afford to dishonor God by living in transgression of his law." ${ }^{203}$ And in the context of the political-religious conspiracy against God's law that she saw coming, White, in an 1885 testimony, observed that "the Judge of all the earth is soon to arise and vindicate His insulted authority." ${ }^{204}$ Thus it seems evident that White continued to see Christ's life and death as the great vindication of God's law, but that in the controversy that rages at the end, God and His people would jointly stand in vindication of His despised law.

\section{The Great Controversy, 1888}

When The Great Controversy was published in 1888, there were not many additions to the coverage of last-day events. Most of the amplification occurred with the 1884 publication of The Spirit of Prophecy, volume 4. Some of the additions are significant, though.

A very interesting study is the amplification and clarification of the conclusion to chapter 29, "The Origin of Evil." The whole chapter in The Great Controversy is roughly doubled in length. In The Spirit of Prophecy, White, having described how Christ's sacrifice unveiled the true character of Satan's position in the controversy over God's

${ }^{203}$ Ellen G. White, "The True Standard of Righteousness," Advent Review and Sabbath Herald, August 25, 1885, 529 (1).

${ }^{204}$ E. G. White, Testimonies, 5:451. 
law, merely states that "God's law stands fully vindicated."205 Two short paragraphs conclude the chapter, showing how all mouths are stopped in the final judgment. The Great Controversy explains the nature of the vindication of God at the cross and at the final judgment. Christ came to earth to die "not merely to accomplish the redemption of man," but "to demonstrate to all the worlds of the universe that God's law is unchangeable. ... The death of Christ proves it immutable." The cross also demonstrates that "justice and mercy are the foundation of the law and government of God."206 Then White explains that on the cross "the death knell of Satan was rung. The great controversy which had been so long in progress was then decided, and the final eradication of evil was made certain." 207 White thus makes clear that the cross was the decisive moment in the cosmic controversy.

But she saves for a new, final paragraph on the execution of the judgment, language regarding the vindication of God before the universe: "The whole universe will have become witnesses to the nature and results of sin. And its utter extermination, which in the beginning would have brought fear to angels and dishonor to God, will now vindicate His love and establish His honor before the universe. ${ }^{, 208}$ In this way it is seen that White sees as of great significance both the events surrounding Christ's life and

\footnotetext{
${ }^{205}$ E. G. White, Spirit of Prophecy, 4:323.

${ }^{206}$ E. G. White, Great Controversy, 503.

${ }^{207}$ Ibid.

${ }^{208}$ Ibid., 504.
} 
death on earth, and also events at the close of history. Both are seen as involved in the vindication of God, though not equally.

Another interesting addition occurs in the 1888 version of the chapter on the time of trouble. In volume four of The Spirit of Prophecy, White, stressing the "magnitude of the ordeal" end-time believers would experience, exhorted her readers to "seek to become perfect in Christ." ${ }^{209}$ She expands and clarifies this in The Great Controversy. She holds up the example of Christ, who "not even by a thought could . . . be brought to yield to the power of temptation. ... There was no sin in Him that Satan could use to his advantage. This is the condition in which those must be found who shall stand in the time of trouble." White leaves little room for misunderstanding what she believes to be required and possible of Christ's followers in the end-time. The next sentence, starting a new paragraph, continues the thought: "It is in this life that we are to separate sin from us, through faith in the atoning blood of Christ." 210

This last sentence seems to leave open the possibility that her actual meaning is the separation from our lives of $\sin$ that is imputed to us, so that sin is separated from us by our acceptance of God's forgiveness, and not so much by our accepting Christ's power to overcome temptation. A partial amplification of her thought may be found in a November 1887 Review article comparing Jesus' life of humility and dependence on God with Saul's self-confidence. She begins the paragraph under consideration, "Would that we could comprehend the significance of the words, 'Christ suffered, being tempted.'
${ }^{209}$ E. G. White, Spirit of Prophecy, 4:440.
${ }^{210}$ E. G. White, Great Controversy, 623. 
While he was free from the taint of sin, the refined sensibilities of his holy nature rendered contact with evil unspeakably painful to him. Yet with human nature upon him, he met the arch apostate face to face, and single-handed withstood the foe of his throne." Then are found the same words as on page 623 of The Great Controversy, starting with "Not even by a thought ...," up to the quote of John 14:30, "The prince of this world cometh, and hath nothing in Me." The paragraph concludes, "The storms of temptation burst upon him, but they could not cause him to swerve from his allegiance to God."211 In the next paragraph, White details the believers' need to overcome as Christ did: "All the followers of Christ have to meet the same malignant foe that assailed their Master. With marvelous skill he adapts his temptations to their circumstances, their temperament, their mental and moral bias, their strong passions. ... We must look to Christ; we must resist as he resisted; we must pray as he prayed; we must agonize, as he agonized, if we would conquer as he conquered." ${ }^{212}$ Apparently, in White's view, the fact that Christ had no "taint" of sin on Him, does not make Him a less suitable pattern for the believer, who struggles with temptations adapted to one's "moral bias" and "strong passions."

White's understanding of the significance of the time of trouble in regard to the vindication of God's law is also seen in a new section on the outpouring of the seven last plagues. By these plagues, God "will vindicate the authority of His downtrodden law.... When Christ ceases His intercession in the sanctuary, the unmingled wrath ... will be

${ }^{211}$ Ellen G. White, "Humility before Honor," Advent Review and Sabbath Herald, November 8, 1887, 689 (1).

${ }^{212}$ Ibid. 
poured out. ... Terrible as these inflictions are, God's justice stands fully vindicated."213 Here again we see White adding language related to an end-time vindication, ${ }^{214}$ though it is in the form of God's wrath poured out on the unrepentant.

Finally, though language directly referring to the 144,000 quickly tapered off after the publishing of young Ellen Harmon's first vision, a new paragraph is inserted in chapter 40, "God's People Delivered," of The Great Controversy, regarding the unique experience of the 144,000. Commenting on the "song of Moses and the Lamb" that this group sings, White declares, "None but the hundred and forty-four thousand can learn that song; for it is the song of their experience-an experience such as no other company have ever had. ... These, having been translated from the earth, ... have endured the anguish of the time of Jacob's trouble; they have stood without an intercessor through the

final outpouring of God's judgments." ${ }^{\text {215 }}$ Whether this group is also unique on account of some measure of preparation needed for the experience they have undergone is a question that has not been answered clearly for us. ${ }^{216}$

\section{Other Pioneer Adventist Authors on End-time Events}

Ellen White was the guiding inspiration for Adventist thought and practice in the early years of the Seventh-day Adventist church. Other Adventist leaders echoed her calls for an urgent preparation for the soon-approaching end. Notable among these

${ }^{213}$ E. G. White, Great Controversy, 627-628.

${ }^{214}$ See pp. 83-84 above.

${ }^{215}$ E. G. White, Great Controversy, 649.

${ }^{216}$ See pp. 49-50, 59-60 above. 
pioneers are James White, J. N. Andrews, and Uriah Smith.

\section{James White}

James Springer White (1821-1881) was the organizational force behind the rising Seventh-day Adventist church in the mid-nineteenth century. Of Christian Connection background, he enthusiastically spread the news of Christ's soon return after hearing Miller's message. After the Disappointment of 1844, he assisted Ellen Harmon in her travels, and they married in 1846. White began publishing soon after the sabbatarian Adventists came together in conferences in 1848, and through the pages of The Second Advent Review and Sabbath Herald led early sabbatarian Adventists toward organizing as a denomination. He served as president of the budding Seventh-day Adventist church for ten of its first seventeen years. ${ }^{217}$

Though White's writings are not as extensive as those of his wife, there is an evident concern for the preparation needed by those expecting to be translated. Editorializing on final events in 1854 , James White warned that the time was coming when there would be "no Intercessor in heaven" and the last plagues would be poured out. He foresaw a "mighty work" to be done to "unite and prepare a people to stand in the day of wrath, and to be translated at the coming of Christ." ${ }^{218}$ He held up the third angel's message of Rev 14 as one of the principal means for accomplishing this. In an editorial in the 1859 Advent Review and Sabbath Herald, he maintained that "the third message"

\footnotetext{
${ }^{217}$ Seventh-day Adventist Encyclopedia, 2d rev. ed. (1996), s.v. "White, James Springer."

${ }^{218}$ [James White], “The Angry Nations," Advent Review and Sabbath Herald, March 7, 1854, 52, 53.
} 
would fit believers "to be translated to heaven without seeing death, ... and to mingle with angels, and all holy men of past ages. What a mighty work to be wrought in men! ... What a yielding of self before Jesus can come in and rule in the heart, and cleanse it from all sin!" 219

James White saw the gifts of the Spirit and the latter rain also as key to last-day preparation of believers. Commenting in 1851 on these gifts and the "unity of the faith" that results (Eph 4:11-13), he argues that "this perfect unity of the faith never has existed since the days of the apostles. It is evidently to exist just prior to the Second Advent, and is to be completed by the 'latter rain,' the 'refreshing from the presence of the Lord,' when the Comforter, the Spirit of truth, is to be poured out in all its fullness." ${ }^{220}$ As he wrote a few months previously, this future "latter rain" of the Spirit was expected to "enable the saints to triumph gloriously." 221

This end-time manifestation of spiritual gifts (including, of course, the ministry of his wife) would fulfill an urgent need. An 1862 editorial opined: “And when we look forward to the great work of fitting the 144, 000 for translation, and this, too, in the midst of the increasing perils of the last days, ... we see a necessity for the manifestation of the

${ }^{219}$ James White, "The Third Message," Advent Review and Sabbath Herald, November 3, 1859, 188.

${ }^{220}$ James White, "Gospel Union," Advent Review and Sabbath Herald, November $25,1851,56$.

${ }^{221}$ James White, “The Angels of Rev. xiv - No. 1," Advent Review and Sabbath Herald, August 19, 1851, 12. 
gifts, such as never before existed." ${ }^{\prime 22}$ In the Whites' 1880 account of their experiences in the Advent movement, James argues for the ongoing need for the gifts of the Spirit, since the mature state of the church mentioned in Eph 4:11-13 has never been reached: "The church to-day is almost infinitely below this state of unity, knowledge, and perfection. And not until the Christians of the last generation of men shall be brought to the enjoyment of it by the last warning message, and all the means God may employ to prepare them to be translated to Heaven without tasting death, will the ultimate design of the gifts be realized." ${ }^{223}$ Thus White held up the ministry of his wife in a way that she could not, as critical to the preparation of those preparing for translation.

Compared to the writings of his wife, the notion of character perfection is mentioned infrequently in the writings of James White. A word-search of his writings included in the Words of the Pioneers CD under the forms of the word "perfect" yields few pertinent results. He does, interestingly, mention the divisions caused in the early phase of the work by those "urging upon the flock extreme views of entire consecration, of Christian perfection, then taught by the Methodists, the men of the Oberlin school, and others. ${ }^{224}$

Another concept that is given much less attention in the writings of James White is the notion of the vindication of God. One relevant quote can be found on the Words of 180.

${ }^{222}$ James White, “The Gospel,” Advent Review and Sabbath Herald, May 6, 1862,

${ }^{223}$ J. White and E. G. White, Life Sketches, 338-339.

${ }^{224}$ James White, Life Incidents: In Connection with the Great Advent Movement as Illustrated by the Three Angels of Revelation XIV (Battle Creek, MI: Steam Press of the Seventh-day Adventists Pub. Association, 1868), 155. 
the Pioneers disk. In a pamphlet on the relation between the law and the gospel, James White criticized non-sabbatarian Adventists for refusing "to obey the law which [Christ] died to vindicate." ${ }^{225}$ Though the thrust of this passage is to establish the perpetuity of the law, and to refute those who claim that the law was done away with by Christ's death on the cross, it does show that, by the 1870 s at least, James White was speaking of the cross as a vindication of God's law.

\section{J. N. Andrews}

John Nevins Andrews (1829-1883) was another of the early Adventist pioneers. He joined the slowly forming sabbatarian Adventists at the young age of seventeen, and served as president of the young Seventh-day Adventist church when in his late thirties. In 1874 he was selected to be the first overseas Adventist missionary, on which assignment he died prematurely at the age of fifty-four. ${ }^{226}$

Andrews is more explicit on the need for a complete overcoming of sin than is James White. In his Sermons on the Sabbath and the Law, published in 1869 and revised in 1870, he reveals his position on the blotting out of the sins of God's people in the judgment: "Their raiment having been washed in Jesus' blood, so that not one stain of guilt remains upon them, last of all, the record of that guilt is removed from the book, and its pages are left as pure as their character has been rendered by the cleansing blood of

${ }^{225}$ James White, The Law and the Gospel: A Treatise on the Relation Existing between the Two Dispensations (Battle Creek, MI: Seventh-day Adventist Publishing Association, [1870?]; reprint, London: International Tract Society, [190?]), 16. See pp. 66-67 above for Ellen White's similar argument.

\footnotetext{
${ }^{226}$ Seventh-day Adventist Encyclopedia, 2d rev. ed. (1996), s.v. “Andrews, John Nevins."
} 
Christ." ${ }^{227}$ Whether character perfection is indicated here is not altogether clear, but statements appearing in a series of editorials from the same period bear witness to his belief that only those who overcame perfectly would be entitled to have their sins blotted out in the judgment. This editorial series, entitled "The Order of Events in the Judgment," was republished in 1890 as The Judgment: Its Events and Their Order. ${ }^{228}$ In discussing the books of record that are used in the judgment, Andrews declares that "the record of the good deeds of the righteous, if it shows that they have overcome all their faults, and perfected the graces of the Spirit of God in themselves, is that which determines that their names shall be retained in the book of life, and their sins blotted out of the books which record them.. ${ }^{, 29}$ Two pages later he adds to a perfect work of overcoming, a full repentance of sin. Speaking of the blotting out of the sins of the righteous, Andrews states that "it will pertain only to those who have fully repented of their sins, and have perfectly accomplished the work of overcoming." Furthermore, Christ "is not needed as priest after that."

Andrews provides further clarification in a subsequent chapter on the offices of

${ }^{227}$ John Nevins Andrews, Sermons on the Sabbath and Law: Embracing an Outline of the Biblical and Secular History of the Sabbath for Six Thousand Years, 2d ed. (Battle Creek, MI: Steam Press of the Seventh-day Adventist Publishing Association, 1870), 96.

${ }^{228}$ John Nevins Andrews, The Judgment: Its Events and Their Order, Bible Students' Library, no. 55 (Oakland, CA: Pacific Press, 1890; reprint, Payson, AZ: Leaves-of-Autumn Books, 1989). There are 20 editorials in the series, beginning with John Nevins Andrews, "The Order of Events in the Judgment - Number One," Advent Review and Sabbath Herald, November 9, 1869, 156.

${ }^{229}$ Andrews, The Judgment, 18.

${ }^{230}$ Ibid., 20. 
Christ. Andrews here again maintains perfect overcoming as a condition for the blotting out of believers' sins:

We need him as priest to confess our names at that tribunal, and to show from the record of our past lives that we have perfected the work of overcoming, so that our sins may, by the decision of the Father, be blotted out, and our names retained in the book of life. But when the people of God have thus passed the decision of the investigative judgment, their probation is closed forever, and their names being found in the book of life, when all that have failed to overcome are stricken therefrom, they are prepared for the standing up of Michael to deliver his people and to destroy all others with the scepter of his justice. ${ }^{231}$

There is one small change in the paragraph here quoted, when it is compared with the editorial that appeared in the Review twenty-one years earlier. Notice the last sentence:

"But when the people of God have thus passed the decision of the investigative Judgment, their probation is closed forever, and their names being found in the book of life, when all that have but partially overcome, are stricken therefrom, they are prepared for the standing up of Michael to deliver his people, and to destroy all other with the scepter of his justice."232 It would be interesting to know who did the editorial work on the 1890 publication, and what influenced the change. In any case, the evidence is quite compelling that Andrews had a rather developed expectation of the character perfection of the saints in the end time.

A question arises as to whether Andrews conceived of a last generation who have "perfected the work of overcoming" in a way not previously seen. In the same chapter he seems to leave open the possibility of a level playing field in the judgment (i.e., all

${ }^{231}$ Ibid., 35-36. Emphasis supplied.

${ }^{232}$ John Nevins Andrews, "The Order of Events in the Judgment - Number Five," Advent Review and Sabbath Herald, December 7, 1869, 188. Emphasis supplied. 
believers are required to be "perfect overcomers" in order to pass the judgment): "It is at that tribunal that the righteous dead are accounted worthy of the resurrection to immortality, and the righteous living are accounted worthy to escape the anguish of the time of trouble, and to stand before the Son of man. Those only can be accounted worthy of this whose record in the book of God's remembrance shows them to have been perfect overcomers." ${ }^{233}$ Of course, "worthy of this" in the last sentence can refer to only the lastmentioned righteous living, who are judged "worthy to escape the anguish of the time of trouble." But it is equally reasonable to include both the dead and the living, seeing that the righteous dead also are judged "worthy" of the resurrection. Evidence which seems to support this is found further in the passage, where Andrews uses the same phrase, "worthy of this," applying it to both groups together: "Those who shall be raised to immortality, and those who shall escape the things coming upon the earth and stand before the Son of man, are severally counted worthy of this before the priesthood of Christ is closed." Similarly, when he argued that believers' sins are blotted out when the books show they "have completed their work of overcoming," he states, "This is manifestly the very time and occasion at which the righteous are accounted worthy of the resurrection to immortality.",234

However, Andrews had made it clear in 1865 that one of the purposes of the three angels' messages was to prepare the last generation in a special way. Speaking of the translation of the living righteous at Christ's coming, he asks, "What will prepare the

${ }^{233}$ Andrews, The Judgment, 44-45. Emphasis supplied.

${ }^{234}$ Ibid., 20-21. 
saints of the last generation for such a distinguished honor?" In the next paragraph he gives the answer:

As the people of God, one by one, have fallen victims to the power of death, an individual work of preparation has been all that was requisite; but when the time comes that all the saints of God who are alive shall in one body be taken into glory, surely something further than an individual work is necessary. By what means shall the saints of God be gathered in one people and prepared for translation? What mighty truths has God in reserve for the last generation, with which to accomplish this great work? In answer to these questions, we cite the fourteenth chapter of Revelation. ${ }^{235}$

Andrews thus follows James White in holding up the three angels' messages as the means of preparing a people for translation. ${ }^{236}$ Again, a question remains whether it is a special level of overcoming that demands a new level of preparation, or merely the fact that the whole body of believers must overcome simultaneously at the end of time.

An interesting variant of end-time events is seen when Andrews presents Josiah Litch's view of the time of the judgment of the living. According to Litch, after the saints are sealed under the sixth seal of Revelation, "“under the seventh seal (chap.8:1) when there is silence in heaven about the space of half an hour; when the great Mediator ceases to plead for sinners, the day of grace ends; then the judgment or trial will proceed on the living inhabitants of the earth.",237 Apparently, the notion of a period of time between the

${ }^{235}$ John Nevins Andrews, "Our Light and Our Responsibility," Advent Review and Sabbath Herald, August 29, 1865, 100. This is also found in the preface of Andrews's The Three Messages of Revelation 14:6-12. John Nevins Andrews, The Three Messages of Revelation XIV, 6-12, Particularly the Third Angel's Message, and Two-Horned Beast, 5th, rev. ed. (Battle Creek, MI: Review and Herald Pub. Co., 1892; reprint, Brushton, NY: TEACH Services, 1998), iv.

${ }^{236}$ See pp. 89-90 above.

${ }^{237}$ Josiah Litch, Prophetic Expositions: Or, a Connected View of the Testimony of the Prophets Concerning the Kingdom of God and the Time of Its Establishment (Boston: 
ending of Christ's mediation and His second coming, as well as a post-probationary trial subsequently undergone by the living (righteous and/or wicked) is not original with sabbatarian Adventists. However, Adventists are clear that the judgment of the living takes place before Christ ends His mediatorial work. ${ }^{238}$ This difference raises the question: Why the severe trial of the believers during the time of trouble, if they have already passed under the scrutiny of the investigative judgment? ${ }^{239}$

In regard to the concept of a last-day vindication of God, Andrews has a little more to say than James White. Many references to vindication of the law seem to arise from the Adventists' struggle to vindicate the Sabbath commandment. ${ }^{240}$ It follows that Andrews speaks of a vindication of God's law in connection with the final meting out of justice to impenitent lawbreakers, whether during the time of trouble or at the execution of the penalty after the millennium. ${ }^{241}$ A word search of the Words of the Pioneers CD's collection of Andrews's works reveals no statements in regard to the law being vindicated

Joshua V. Himes, 1842), 49-54; quoted in John Nevins Andrews, The Judgment: Its Events and Their Order, Bible Students' Library, no. 55 (Oakland, CA: Pacific Press, 1890; reprint, Payson, AZ: Leaves-of-Autumn Books, 1989), 97.

${ }^{238}$ See E. G. White, Great Controversy, 490.

${ }^{239}$ For a discussion of this point, see pp. 322-323 below.

${ }^{240}$ This in fact leads to the mark of the beast, Andrews declares. John Nevins Andrews, "The Three Angels of Rev. XIV, 6-12," Advent Review and Sabbath Herald, April 17, 1855, 209.

${ }^{241}$ John Nevins Andrews, Review of the Remarks of O. R. L. Crozier, on the Institution, Design and Abolition of the Sabbath (Rochester, NY: Advent Review Office, 1853), 38, 45-46. 
by Christ's death, but Andrews does point to the words of Christ and the apostles as serving to vindicate its immutability. ${ }^{242}$

\section{Uriah Smith}

Uriah Smith (1832-1903) was editor of the Review from 1855 until his death in 1903, except for two short periods of two to four years each. He is known best for his exposition of the prophecies of Daniel and Revelation. He argued forcefully against the new view of the law set forth by A. T. Jones and E. J. Waggoner around the time of the 1888 General Conference session, striving to maintain the Adventist regard for the perpetuity of the Ten Commandments and the seventh-day Sabbath. ${ }^{243}$

Following the lead of other Adventist writers, Smith emphasized the preparation needed for the coming crisis. In an 1861 Review editorial on the parable of the wedding garment, both repentance and character development are held forth as conditions to be met for sins to be blotted out in the cleansing of the sanctuary, but the expression is not as precise as that of Andrews:

[God] has seen fit to reveal to us the fact that a book of records is kept, and that it is by that record that men are to be judged, and by that record their characters determined. An investigation of these records must therefore take place previous to the coming of Christ. The sins of those who have repented will be blotted out, and their names retained in the Lamb's book of life; while the sins of those who have not sought forgiveness and pardon, will stand against them, and their names will be blotted out of the book of life. This investigation of character, this blotting out of sins, is, as we have seen, the last work performed in the heavenly sanctuary previous to the close of probation, and the marriage of the Lamb. This is the coming in of the King to see the guests - to determine, as characters pass in review before the great

${ }^{242}$ John Nevins Andrews, The Perpetuity of the Royal Law: Or, the Ten Commandments Not Abolished (Rochester, NY: Advent Review Office, 1854), 28.

${ }^{243}$ Seventh-day Adventist Encyclopedia, 2 d rev. ed. (1996), s.v. "Smith, Uriah." 
tribunal of heaven, who they are, who are worthy of translation, and a part in the first resurrection when the angels are sent forth to bring those who are prepared, to the marriage supper of the Lamb. ${ }^{244}$

This leaves us with two questions: (1) Does Smith mean to convey the idea that character is measured by the record of repentance of sin, or is he abruptly switching back and forth between character development and repentance as preconditions for the blotting out of sins? and (2) Is there any difference in what is required to be declared "worthy of translation" and that needed to join those who have "a part in the first resurrection"? The identification of true repentance as determinative of character, especially as it is evidenced in a change of life, could be a helpful insight. But it is unlikely that Smith's words could be thus used to develop such a refined position, one more appropriate to the concerns of twentieth-century Adventists. It seems more likely that Smith, along with other Adventists during these formative years of the $1860 \mathrm{~s}$, did not see the need to distinguish between overcoming (change in behavior) and repenting (change of heart) in connection with the end-time judgment. ${ }^{245}$

As to whether or not Smith believed that the same conditions apply for both translation and resurrection, remarks Smith made in introducing a short article a year later are perhaps instructive. The "one exception" to the article, which deals with the urgency of being ready to die, is "the righteous living who are to be translated when Christ

\footnotetext{
${ }^{244}$ Uriah Smith, "The Wedding Garment," Advent Review and Sabbath Herald, April 2, 1861, 156.

${ }^{245} \mathrm{Cf}$. Ellen White's earlier accounts of the investigative judgment and the blotting out of sins, which focus on repentance and confession, with her later accounts, in which she gives much greater stress to overcoming, as well as repentance. E. G. White, Early Writings, 48; idem, Great Controversy, 487-489.
} 
appears; and these can hardly be called an exception since the change they then experience is equivalent to death and the resurrection, and the preparation required for this change, is more difficult than that demanded of those who enter into life through the gates of the grave. ${ }^{246}$ Smith does not elaborate on what is more difficult about the preparation needed for translation. But in an editorial a few years earlier against those who criticized the Adventists' preoccupation with preparing for the Advent, Smith maintained that "a special preparation" was a "requisite qualification" for those expecting the soon return of Christ. In so doing, though, he made clear his understanding that "moral character must be the same in all ages in those who are candidates for the kingdom of heaven." The "position" of those who lived long ago and those living in the last days "must be similar in many particulars." Smith defines what may be dissimilar about the position of those specially prepared for the end: "To be ready for the coming of the Lord calls for a degree of action, of devotedness, and separation from the world, involved in no other position."247 It seems, then, that Uriah Smith is not as explicit in regard to the notion of complete overcoming, contrary to what is seen in the works of Ellen White and J. N. Andrews.

From a word search of Words of the Pioneers for appearances of variations of "vindicate" in Smith's earlier works, evidence appears for a basic appreciation of the concept of the vindication of God in the great controversy. "The justice of God will stand

\footnotetext{
$1862,66$.

${ }^{246}$ Uriah Smith, “[Editor's Note]," Advent Review and Sabbath Herald, July 29,

${ }^{247}$ Uriah Smith, "'If We Are Only Ready," Advent Review and Sabbath Herald,
} November 10, 1859, 196. 
vindicated" in the outpouring of the last plagues, according to an 1857 editorial by Smith. Similarly, in an 1864 work against T. M. Preble's anti-sabbatarian views, Smith states that "the time draws near when God will arise to vindicate the honor of his own name and law."248 The need for God's vindication is also brought in by Smith in his 1884 presentation of the Adventist view of the annihilation of the wicked in Man's Nature and Destiny. After caricaturing the predicament of those wishing to believe in a loving God while also holding to the eternal punishment of the wicked, Smith asks, "If, on the other hand, the record shows that God's government can be vindicated" while the wicked are annihilated, "can any one ... hesitate, on this account, to join in the ascription, 'Great and marvelous are thy works, Lord God Almighty; just and true are thy ways, thou King of saints?"'249 Smith here reveals an obvious perception of the significance of the great controversy and its final resolution in end-time events.

\section{Other Authors}

Many other Adventists in this pre-1888 period shared a concern for gaining the needed preparation for translation and for facing the coming time of trouble, as well as a growing awareness of the importance of the issues of the great controversy and their

${ }^{248}$ Uriah Smith, "The Seven Last Plagues," Advent Review and Sabbath Herald, June 18, 1857, 52; Uriah Smith, Both Sides on the Sabbath and Law: Review of T. M. Preble (Battle Creek, MI: Steam Press of the Seventh-day Adventist Pub. Association, 1864), 200.

${ }^{249}$ Uriah Smith, Man's Nature and Destiny: Or, the State of the Dead, the Reward of the Righteous, and the End of the Wicked, 3d ed., rev. and enl. (Battle Creek, MI: Review and Herald, 1884), 12-13. Cf. idem, Daniel and the Revelation: The Response of History to the Voice of Prophecy, a Verse by Verse Study of These Important Books of the Bible (Nashville: Southern Pub. Association, 1907), 683, 717. 
impact on last-day events. After a sampling of early Adventist letters to the Review, passages from three Adventist leaders will be briefly examined in this section, namely R. F. Cottrell, D. T. Bourdeau, and J. H. Waggoner.

\section{Hoping and Praying to Be Ready}

Shortly after $A$ Sketch of the Christian Experience and Views of Ellen G. White was published in the summer of 1851, including its clear statements on the holiness needed to stand through the oncoming time of trouble, serious letters began coming in to the Review. ${ }^{250}$ On November 30 a Rebekah Whitcomb wrote that she had "never realized so fully, how holy, harmless and undefiled we must be, as since I attended the conference at Washington, and witnessed the visions God gave there." She reports realizing that believers "must be holy, as no other people ever were, to live in the sight of a Holy God, without an Intercessor." 251 Similarly, "Sister P. M. Bates" (Prudence M. [Nye] Bates, the wife of Joseph Bates) wrote on December 12: "Since the Medford Conference, I have felt more sensibly, then ever before, the need of entire consecration to God, and realize, in some degree, how pure and holy we must be to stand before him without a Mediator. O, how I tremble and weep before him, when I think what a poor unworthy creature I am. Then, how precious is Jesus to me. He is my only hope." ${ }^{, 252}$ And on January 14, Sarah

${ }^{250}$ See pp. 33-35, 37-38 above for a discussion of Ellen White's earliest mentions of the need to live through the time of trouble without a Mediator.

${ }^{251}$ Rebekah Whitcomb, "From Sister Whitcomb," Letter to the Editor, Advent Review and Sabbath Herald, December 23, 1851, 67.

${ }^{252} \mathrm{P}$. M. Bates, extract of letter to the editor, Advent Review and Sabbath Herald, December 23, 1851, 72. Cf. EGW Encyclopedia, forthcoming, s.v. "Bates, Prudence M. (Nye)." 
Griggs expressed her yearning for the needed preparation: “O, my Saviour, grant us that preparation we must have to live in this mortal state and be accepted of God without a mediator. I want the preparation now and dare not put it off, expecting to receive it at the descent of the latter rain." ${ }^{, 253}$

A similar sentiment is expressed in a letter from Eliza Smith in 1859. After apologizing for previously speaking against Ellen White, she writes, "I am striving to overcome and get ready for that time which is close at hand, when our great High Priest will have finished up his work in the Sanctuary, and we be left without a mediator. O Lord, help me to prepare for that decisive hour." ${ }^{254}$ It is remarkable that all of the letters examined here are from Adventist women, who were perhaps more expressive or enjoyed a deeper religious experience. These letters from the 1850 s are a snapshot of the spirit of the early sabbatarian Adventist believers, and the high regard that had developed for Ellen White's gift.

\section{R. F. Cottrell}

Roswell F. Cottrell (1814-1892) joined the sabbatarian Adventists around 1851, and soon became active in writing and ministerial labors. ${ }^{255}$ His articles in the Review show his focus on the need to prepare for translation. As early as 1853 he spoke of the

${ }^{253}$ Sarah Griggs, "From Sister Griggs," Letter to the Editor, Advent Review and Sabbath Herald, February 3, 1852, 88.

${ }^{254}$ Eliza Smith, "From Sister Smith," Letter to the Editor, Advent Review and Sabbath Herald, April 21, 1859, 175.

${ }^{255}$ Seventh-day Adventist Encyclopedia, 2d rev. ed. (1996), s.v. "Cottrell, Roswell F." 
Sabbath as "the final test to prepare a people for translation at the coming of Jesus."256 By 1859 he was exhorting believers to "strive for holiness, for entire consecration, perfect sanctification.... We must, if we would be translated as Enoch and Elijah were, walk with God as they did."257 The following year Cottrell warned believers that if they indulged in "evil" or "unsubdued passions," "fretfulness," and "scolding," "how ill prepared are we to be translated into a state of perfect peace. ${ }^{n 258}$ In 1884, in a series on the cleansing of the sanctuary, Cottrell continued to raise the bar high for believers expecting to have their sins blotted out: "If we have faith in what God has revealed to us, and deny ourselves of all ungodliness and worldly lusts, consecrate ourselves to the service of God, and labor for our fellow-men in a self-sacrificing way, evincing a true missionary spirit, we shall have our sins blotted out and be accounted worthy to have a part in the world to come." 259

Besides expressing the need for complete sanctification, Cottrell placed end-time believers squarely in the middle of the great controversy. During a series of articles on “The Closing Messages" in 1869, Cottrell strongly held up the third angel's message as key to preparing the "last generation" for translation at the advent of Christ:

${ }^{256}$ Roswell F. Cottrell, "Simplicity of Bible Truth," Advent Review and Sabbath Herald, May 12, 1853, 204.

${ }^{257}$ Roswell F. Cottrell, "Holiness," Advent Review and Sabbath Herald, February $10,1859,93$.

${ }^{258}$ Roswell F. Cottrell, "No Scolding," Advent Review and Sabbath Herald, March $8,1860,125$.

${ }^{259}$ Roswell F. Cottrell, "The Cleansing of the Sanctuary - No. 4," Advent Review and Sabbath Herald, April 1, 1884, 219. 
For this purpose [preparation for translation], and to vindicate his holy law and the righteousness of those judgments he is about to execute upon the world of the ungodly, he has prepared a testing message which, in its result, will exhibit before men, such a people as the world has not seen since the dark ages of papal apostasy and usurpation. Those who bear the test, purifying themselves, and honoring God by keeping his commandments and the faith of Jesus, he will honor with translation. ${ }^{260}$

Thus Cottrell sees the third angel's message purifying a people whom God will use to vindicate His law. Nearly two decades later Cottrell also highlighted Christ's role in vindicating the claims of God's law. In an article on Christ's magnifying of the law, he states that Christ "would vindicate its claims" by His many teachings on the law and by His example. "But in nothing did he magnify and honor it more than in his death for our transgressions of it." ${ }^{, 61}$

\section{T. Bourdeau}

Daniel T. Bourdeau (1835-1905), one of the first sabbatarian Adventists of French descent, was an evangelist and missionary to both his native French-speaking peoples and to English speakers, having entered upon ministerial work in $1858 .^{262}$ Bourdeau's Sanctification: Or, Living Holiness, published in 1864, stresses the need for complete, though not instantaneous, sanctification. Though "sanctification is a progressive work," "a special preparation will be required of the last church. A partial sanctification is not sufficient for the church living under the blazing light of the last

${ }^{260}$ Roswell F. Cottrell, “The Closing Message - No. 19," Advent Review and Sabbath Herald, December 21, 1869, 205.

${ }^{261}$ Roswell F. Cottrell, "Magnifying the Law," Advent Review and Sabbath Herald, February 9, 1886, 82.

${ }^{262}$ Seventh-day Adventist Encyclopedia, 2d rev. ed. (1996), s.v. "Bourdeau, Daniel T.' 
message of mercy. They must be 'wholly' sanctified."263 After making the point that humans have always been able to obey, Bourdeau explains why those in the last days are required to make a "special preparation":

They will need to be wholly sanctified, not only because of the additional truths which will be brought to light, and be made in a special manner obligatory upon them, but also because they will have to pass through the time of trouble without a mediator between God and them. ... When this time of trouble comes, there can be no Mediator between God and man; for the unmingled wrath of God cannot be poured out till mercy closes; and when mercy closes, Christ's mediatorial work will cease, and from that time onward there can be no pardon and no change in the characters of men. ${ }^{264}$

Thus two reasons are given for complete sanctification: (1) added light which brings added responsibility; and (2) no mercy for those who have not gotten rid of all sin prior to probation's close.

Faced with the prospect of living without a Mediator in the heavenly sanctuary, Bourdeau admonishes Review readers in 1867, "We must escape for our lives, by walking in the path of duty, and overcome every sin, by living out the whole truth, that we may be able to pass through the time of trouble without an intercessor, and be found of Christ without spot and blameless at his coming. ... We should not be satisfied till we have escaped to the mountain, till we have reached the pinnacle of holiness." ${ }^{265}$ Two years later, reporting on the pioneer work in California, he stresses again the need for perfect overcoming: "How important that we overcome all our sins, in order to pass through the

${ }^{263}$ Daniel T. Bourdeau, Sanctification; or, Living Holiness (Battle Creek, MI: Steam Press, 1864; reprint, Nashville: Southern, 1970), 19.

${ }^{264}$ Ibid., 104.

${ }^{265}$ Daniel T. Bourdeau, "Advances of God's People under the Messages, and the Dangers of Backsliding," Advent Review and Sabbath Herald, February 19, 1867, 122. 
time of trouble without a Mediator, and to be without spot and blameless at Christ's coming. We are safe only as we put away our sins, and draw near to God." Bourdeau maintains that perfection is the purpose of church organization: "The leading object of organization is to help in perfecting the church. But as we enter into simple organization we should do it with such a sense of sacredness and thoroughness of the character of the work for these last days, as will help us to start aright, and as will follow us in overcoming till we shall reach the pinnacle of perfection." Having observed that God required Israel to cleanse themselves physically and spiritually on the way to Canaan, Bourdeau is pleased to report that some of the interested ones in California "are overcoming the use of tobacco, tea, and coffee. ${ }^{.266}$

Bourdeau was somewhat less positive about his own level of overcoming fifteen years after publishing Sanctification. While still holding to a rigorous view of man's part in the work of overcoming all defects, in an 1879 Review article refuting instantaneous sanctification Bourdeau confessed, "Several years have passed since I wrote a treatise on sanctification, agreeing with this article; and the series of purifying trials through which I have since passed has convinced me that I then had unsanctified traits of character that I did not fully see, and that I was not so far advanced in the work of sanctification as I thought I was." Nevertheless he is not deterred, as he perceives that "those who are the farthest advanced in sanctification are the last ones to boast of it. As they draw near to God, and get a clearer view of Jesus, the perfect Pattern, they see defects in their characters and the importance of making greater efforts to overcome them." He then

${ }^{266}$ Daniel T. Bourdeau, "Report from California," Advent Review and Sabbath Herald, February 23, 1869, 69. 
makes a helpful observation in regard to a question that is generally passed over in the early Adventist literature; that is, if perfection of character is required of all for entrance to heaven, and there is no change in character at the moment of glorification or resurrection, what hope is there for those who die prematurely, before the progressive work of sanctification is appropriately completed? "Should they die without a knowledge of these sins [of ignorance], the righteousness of Christ would be imputed to them, and they would be accounted holy, Christ being unto them sanctification as well as justification.... But the blood of Christ never cleanses from known sins that are not repented of." ${ }^{267}$ Bourdeau thus mercifully leaves open the door to salvation for imperfect believers who die without having overcome all their defects. But there is no mention in the early SDA literature for such mercy on behalf of those who come up to the close of probation with remaining character defects.

\section{J. H. Waggoner}

Joseph Harvey Waggoner (1820-1889) joined the sabbatarian Adventists in 1852, and quickly became one of the leading evangelists and writers of the group. ${ }^{268}$ Similarly to Cottrell and Bourdeau, Waggoner expressed a view of character perfection that was uncompromising. Reporting in the Review on his labors in Iowa in 1861, he "deeply deplored" the fact that any of the newly forming Seventh-day Adventist church would have "such limited views of the work before us," that when told that the gifts of the Spirit

${ }^{267}$ Daniel T. Bourdeau, "Refutation of Instantaneous Sanctification," Advent Review and Sabbath Herald, November 27, 1879, 170. Harvey."

${ }^{268}$ Seventh-day Adventist Encyclopedia, 2d rev. ed. (1996), s.v. "Waggoner, Joseph 
were to bring the church into a state of perfection and unity, "it was replied that such a state of things would never be before the Lord comes!” Waggoner echoes James White in pointing to the key role of Ellen White in preparing a last-day people for translation:

"If it is supposed that we can stand in the time of trouble and be translated without perfection, or gathered without unity, we cannot wonder that they feel no necessity of the gifts of the Spirit of God." ${ }^{269}$ According to Waggoner, this preparation for translation, as attested by Ellen White, included the body as well as the spirit. Speaking of the general interest in health reform at the time, Waggoner contrasts the careless attitude of nonbelievers with that of Adventists, who had been shown that health reform was "the means whereby a weak people may be made strong to overcome, and our diseased bodies cleansed and fitted for translation., ${ }^{270}$

Of all the writers in this pre-1888 period, Waggoner is the most thorough in regard to the need for, and the method of, God's vindication in the story of human sin and redemption. As early as 1853 , in a series on the law, Waggoner expressed a concern for "the principles which God must maintain, in order to vindicate his justice" when those principles are violated by His creatures. ${ }^{271}$ In the last paragraph of the concluding article of this series, Waggoner, referring to the time of trouble, declares, "Soon God, in

${ }^{269}$ Joseph Harvey Waggoner, "Meetings in Southern Iowa," Advent Review and Sabbath Herald, August 6, 1861, 76. On James White's view of the necessity of the gifts of the Spirit in the last days, see pp. 90-91 above.

${ }^{270}$ Joseph Harvey Waggoner, "Present Truth," Advent Review and Sabbath Herald, August 7, 1866, 77.

${ }^{271}$ Joseph Harvey Waggoner, "The Law of God: An Examination of the Testimony in Both Testaments (Continued)," Advent Review and Sabbath Herald, November 22, $1853,154$. 
judgment will vindicate the honor of his holy law."272

Before turning to Waggoner's first systematic treatment of the issues of atonement and vindication, in a series of articles in the Review during 1863-1864, it may be helpful to notice another series on the atonement, by J. M. Stephenson in 1854. Stephenson, a convert of Waggoner's, about a year after this series was published in the Review, defected from the sabbatarian Adventists over his different views of the millennium. ${ }^{273}$ Stephenson pointed to Christ as the only Substitute for the human race, one who could vindicate God's government. He asks, 'Upon what principle can God forgive sins and maintain the honor of his government, and the authority of his law?" He then argues that God provided Christ as the only one who could "meet the demands of his law, and vindicate the honor of his government."274 The next week Stephenson wrote that God's sacrifice of His Son "vindicates the rectitude of his 'holy, just and good' law," evidenced by God's acceptance of the sacrifice as "absolutely perfect, as far as plenitude and efficiency is concerned." 275

Waggoner's first series on the atonement, published from 1863 to 1864 , laid out an extensive examination of the issues in the salvation of humans. Waggoner set the

\footnotetext{
${ }^{272}$ Joseph Harvey Waggoner, "The Law of God: An Examination of the Testimony in Both Testaments (Concluded)," Advent Review and Sabbath Herald, July 25, 1854, 196. See also Joseph Harvey Waggoner, "The Nature and Tendency of Modern Spiritualism," Advent Review and Sabbath Herald, February 4, 1858, 99.

${ }^{273}$ Seventh-day Adventist Encyclopedia, 2d rev. ed. (1996), s.v. "Messenger Party."

${ }^{274}$ J. M. Stephenson, "The Atonement (Continued)," Advent Review and Sabbath Herald, October 31, 1854, 89.

${ }^{275}$ J. M. Stephenson, “The Atonement (Continued)," Advent Review and Sabbath Herald, November 7, 1854, 99.
} 
groundwork by asserting that, considering the mix of good and evil in the present state, "without a written revelation, it is not possible to vindicate the justice and benevolence" of God. ${ }^{276}$ In his discussion of the situation of a moral government that is under attack, he underscores the notion of vindication: "The very idea of a moral government leads us to look forward to a vindication of the right principles or laws now trampled upon." The very fact of a human conscience which looks forward to a judgment in which "injured innocence [is] exalted and vindicated" is "a sure vindication of the divine government in regard to the anomalies of the present state"277 In looking at the biblical evidence for the atonement, Waggoner reasons that the "chief object" of the atonement is "the honor of the law," and that the "Law of God is honored by the death of his Son.,"278

Waggoner published other series of articles on the atonement after republishing the first series in book form in $1868 .{ }^{279}$ In his 1874 series in the Review he expanded his discussion of the qualifications that Christ possessed as the vindicator of God's violated law: "He possessed the requisite dignity to magnify and vindicate the honor of the law of his Father in suffering its penalty.... In him were blended 'the brightness of the Father's glory' and the weakness of 'the seed of Abraham.' In himself he united the Law-giver to

${ }^{276}$ Joseph Harvey Waggoner, "Reason Not against an Atonement," Advent Review and Sabbath Herald, June 2, 1863, 1.

${ }^{277}$ Joseph Harvey Waggoner, “The Moral System," Advent Review and Sabbath Herald, June 9, 1863, 13.

${ }^{278}$ Joseph Harvey Waggoner, "The Nature of the Sacrifice: The Son of God Died," Advent Review and Sabbath Herald, October 27, 1863, 173.

${ }^{279}$ Joseph Harvey Waggoner, The Atonement: An Examination of a Remedial System, in the Light of Nature and Revelation (Battle Creek, MI: Steam Press of the Seventh-day Adventist Pub. Association, 1868). 
the law-breaker - the Creator to the creature." Waggoner here shows his understanding of Christ as the necessary link between the "throne of glory" and "the nature of fallen man. ${ }^{" 280}$ In a related series on the law in 1875 , Waggoner seems to clarify somewhat the aspects of vindication that came to focus at the cross: "The death of Christ is an offering to vindicate the integrity of the law of God, and thus to enable God to dispense mercy and pardon without impairing the integrity of his government.".281

In the third edition of The Atonement, published in 1884, Waggoner added a few insights worth noting. In his discussion of the purpose of Christ's sacrifice, he reasons that it was not merely to save lost humans:

Not only the life of man, but the honor of God is at stake. Shall Satan be permitted to triumph, and man be utterly ruined and blotted from the earth? Or shall the divine Lawgiver relax the strictness of his law, and so let man escape the penalty which he had incurred? Either would dim the glory of the Most High. Either would cause 'the sons of God,' who 'shouted for joy' when the foundations of the earth were laid, to vail their faces in astonishment and in sorrow. God, whose love and justice are alike infinite, determined to open a way whereby man might be recovered from his fall, and the integrity of the law be maintained, and its claims fully honored. ${ }^{282}$

Waggoner clearly portrays the dilemma that human disobedience presented the divine government. It seemed that Satan won either way. God could cause the race to be blotted from the face of the earth, or He could relax His requirements. In another section,

\footnotetext{
${ }^{280}$ Joseph Harvey Waggoner, "The Atonement - No. 12,” Advent Review and Sabbath Herald, April 21, 1874, 150.

${ }^{281}$ Joseph Harvey Waggoner, "The Law of God - No. 15: Dead to Sin," Advent Review and Sabbath Herald, June 24, 1875, 201.

${ }^{282}$ Joseph Harvey Waggoner, The Atonement: An Examination of a Remedial System in the Light of Nature and Revelation, 3rd ed. (Oakland, CA: Pacific Press, 1884; reprint, as The Atonement in the Light of Nature and Revelation, Brushton, NY: TEACH Services, 1997), 140-141.
} 
Waggoner calls attention to the final vindication of God's government in the judgment of the wicked: "One important end which will be gained by this examination of the cases of all the wicked by the record of their lives, is the complete vindication of the Government and providence of God. ${ }^{283}$ Vindication of God's government during the millennial review would seem to involve something different from the vindication Christ achieved on the cross. Waggoner's words to the effect that Christ's sacrifice enabled God to justly pardon sinners may be helpful at this point. Perhaps the judgment (of both the righteous and the wicked) enables God to justly be selective in pardoning certain sinners and executing others. ${ }^{284}$ In any case, Waggoner was a pioneer among Seventh-day Adventists in focusing attention on the need for vindication of the government of God. Whereas Adventists (including Waggoner) saw their proclamation and observance of the seventhday Sabbath as serving to vindicate the downtrodden law of God, ${ }^{285}$ Waggoner also emphasized the cosmic struggle over divine law in general, and the questions arising from the divine solution to human rebellion.

\section{Summary and Conclusion}

Thus far a good deal of material has been examined that has a bearing on Andreasen's views. O. R. L. Crosier's denial of atonement at the cross was a vital

${ }^{283}$ Ibid., 267.

${ }^{284}$ See p. 112 above, quoting from J. H. Waggoner, "The Law of God - No. 15: Dead to Sin," 201.

${ }^{285}$ See, for example, Andrews, “The Three Angels of Rev. XIV, 6-12,” 209; U. Smith, Both Sides on the Sabbath and Law: Review of T. M. Preble, 200; Joseph Harvey Waggoner, "Who Changed the Sabbath? (Concluded)," Advent Review and Sabbath Herald, December 20, 1887, 795 (11). 
influence on the sabbatarian Adventists. Serving to validate the 1844 date and the significance of an eschatological work of Christ in the plan of redemption, it is fundamental for understanding Adventist eschatology in general, as well as Andreasen's last-generation view in particular. Joseph Bates gave early support for the idea of complete obedience to the law as a needed quality for those preparing to be sealed in anticipation of translation.

The writings of Ellen White provide an abundance of material for analysis. Her early attention to the 144,000 set the tone for an ongoing emphasis on the qualities of faith and character perfection needed by those preparing for translation. From virtually the beginning of the organization of the sabbatarian Adventists, her warnings to make preparations to stand before God without a Mediator after the close of probation made a deep impact. Though perhaps having mellowed as the years advanced, as she spent time filling out the picture of the great controversy as seen in the Bible story, her warnings are no less substantial as she entered the $1880 \mathrm{~s}$, but rather become in some respects more pointed, and less ambiguous.

Rather surprisingly, Ellen White seems to have set the standard of overcoming in the same place, whether the believer is to be resurrected or translated. To be sure, a special trial of faith is anticipated during a soon-coming, post-probationary time of trouble, requiring a special preparation. However, if the preparation that is required is perfection of character, it is not easy to see how this is a unique or special requirement for those passing through the time of trouble. In White's view, the same preparation is needed by those facing death and resurrection. It is clear that she looked forward to a people at the end of time who would have gained the victory over every defect of 
character before the close of probation. What is not clear, though, is how, or even whether, she understood this to be an experience uniquely applicable to the last generation.

From the 1870s Ellen White began to make use of the language of vindication of the divine law in connection with her expansion of the great controversy theme. Initially, this was in connection with the life and death of Christ, but later the subject of an endtime vindication of God's honor can be seen.

In the 1880s, with the publication of the last volume of The Spirit of Prophecy, followed just four years later by the expanded Great Controversy, a very clear portrayal of last-day events emerged. Readers are presented with a consistent portrayal of almost superhuman testing of the 144,000 , a group of people who apparently feel very unsure of themselves. Surprisingly, the same language that White uses for this post-probationary testing is used in describing the finishing of the sealing work before the close of probation. This can be seen to militate against the idea of a unique experience undergone during the time of trouble. On the other hand, it may indicate that Ellen White's mental outline of end-time events was not as firm as that which has been extracted from her writings by others.

Other Adventist writers obviously shared the same views in regard to the last generation. Somewhat surprisingly, James White had relatively little to say about character perfection. J. N. Andrews is clear, though, on the necessity of complete overcoming. Uriah Smith shows a basic appreciation for the need for divine vindication in the great controversy. This study also found a bit of ambiguity in his descriptions of what is needed to pass the judgment and have one's sins blotted out—an ambiguity with 
significance for Adventist concepts of salvation and eschatology.

Finally, the yearnings of early sabbatarian Adventists to be ready for the time when they would have to stand without a Mediator are revealing. And other early writers seem willing to go even farther than Ellen White in what is needed to be ready for the last days. R. F. Cottrell seems to have predicted some of Andreasen's ideas, with his last-day vindication of God's law and a people who would demonstrate what had not been seen since the Christian apostasy of the dark ages. D. T. Bourdeau emphasized complete sanctification in his ministry and writings, even as he realized in later years how far he had been from the goal. And J. H. Waggoner, more than anyone else, expounded the deeper issues in the plan of salvation, and the need for vindication of the divine government. 


\section{CHAPTER 3}

EMERGENCE OF FINAL-GENERATION CONCEPT, 1888-1915

\section{Introduction}

In 1888 Seventh-day Adventist leaders were confronted with a striking presentation of righteousness by faith by A. T. Jones and E. J. Waggoner, editors of the Adventist evangelistic journal, Signs of the Times. Supported by Ellen White, these young men quickly rose to prominence in the church. A study of the writings of these and other leaders up through the closing years of Ellen White's life is here undertaken in order to trace the development of last-generation themes in Adventism in the post-1888 years. Ellen White's views will be examined in order to discover any new emphases, and also to review previous positions respecting end-time events related to final-generation concepts. Then will be examined pertinent passages from the writings of Jones and Waggoner, through whom these concepts first came to be clearly expressed. Finally, the writings of other Adventist leaders of the period will be searched for evidences of sympathy with the more concretely expressed final-generation concepts of Jones and Waggoner.

\section{Ellen White's Post-1888 Outlook on End-Time Events}

Ellen White lived for over twenty-five years after the 1888 General Conference session, and continued to guide the growing denomination. Her statements in this period 
follow closely those of earlier years, with little added information for the purposes of this study. But in perusing some of White's writings of this later period, one may see the consistency of her views over time. Though she clearly welcomed the message of righteousness by faith that came to prominence in connection with the post-1888 years, her basic eschatological outlook stood unchanged. Despite fears of church leaders that acceptance of the Jones-Waggoner teaching on the law in Galatians would nullify Adventist teaching about the necessity of obedience to the law, especially the Sabbath, White seems to have not shared their fears of an antinomian drift. While proclaiming the life-transforming gospel of the righteousness of Christ, she maintained her urgent call for preparation of church members for the trying times to come. She did not alter her views on either the possibility or the necessity of character perfection. And she continued to emphasize the importance of the vindication of God's law in the closing conflict of the controversy between Christ and Satan.

Preparation for the End

In the last twenty-seven years of her life (1888-1915) Ellen White continued to call on believers to make preparations for the times ahead of them. As in previous years, she continued to point to what was required to receive the latter rain and the seal of God, which would enable them to pass safely through the time of trouble and be translated to heaven without dying at the second coming of Christ.

\section{The Latter Rain}

In the years immediately following the 1888 General Conference session, White gave considerable attention to the need of receiving the outpouring of the latter rain, the 
end-time manifestation of the power of the Holy Spirit. Just as during the $1860 \mathrm{~s},{ }^{1}$ she reproved Adventists for their lack of readiness to receive this indispensable gift. Now, in a letter to the General Conference around 1889, she chides leaders for clinging to divisive "roots of bitterness brought from the conference at Minneapolis," on account of which they are not prepared to receive the loud cry and the latter rain. ${ }^{2}$

Two years later, before White left for Australia in the fall of 1891, she twice stressed the need to purify the human "vessels" in order to be ready for the latter rain. Speaking at a workers' meeting in Michigan in 1891, she asked ministers, "Are our vessels ready to receive the heavenly dew? Have we defilement and sin in the heart? If so, let us cleanse the soul temple, and prepare for the showers of the latter rain." ${ }^{3}$ In another sermon in September in which she called attention to the fact that the "the third angel's message is swelling into a loud cry," she used similar language:

Today you are to give yourselves to God, that he may make of you vessels unto honor.... Today you are to have your vessel purified that it may be ready for the heavenly dew, ready for the showers of the latter rain; for the latter rain will come, and the blessing of God will fill every soul that is purified from every defilement. It is our work today to yield our souls to Christ, that we may be fitted for the time of refreshing from the presence of the Lord—fitted for the baptism of the Holy Spirit. ${ }^{4}$

${ }^{1}$ See pp. 50-51 above.

${ }^{2}$ Ellen G. White to the General Conference, c. 1889, Letter 24, 1889, published, in part, in Manuscript Releases: From the Files of the Letters and Manuscripts Written by Ellen G. White, 21 vols. (Silver Spring, MD: E. G. White Estate, 1981-1993).

${ }^{3}$ Ellen G. White, “'What Shall We Do, That We Might Work the Works of God?" (Concluded)," sermon at workers' meeting, Grand Rapids, MI, Advent Review and Sabbath Herald, April 21, 1891, 242.

${ }^{4}$ Ellen G. White, “'It Is Not for You to Know the Times and the Seasons," Advent Review and Sabbath Herald, March 22, 1892, 178 (2). 
In these passages can be noted a characteristic emphasis on readiness for future events, and the requisite purity of heart and soul.

\section{The Sealing}

As seen in chapter 2, the sealing also prepares believers for the time of trouble that comes after the close of probation. ${ }^{5}$ In 1899 White made it clear that the seal of God would be received when God's people attain to character perfection: "Are we seeking for his fulness, ever reaching higher and higher, trying to attain to the perfection of his character? When God's servants reach that point, they will be sealed in their foreheads." Thus White does not change her view that perfection of character is a necessary preparation for end-time believers, even at this late stage in her career.

\section{The Time of Trouble}

Besides holding to the early Adventist positions on the latter rain and the sealing, Ellen White also continued to foresee a period of conflict and trial for God's people before the second coming of Christ. In the year after the Minneapolis General Conference, she warned in a private letter to a Dr. Burke of "the fast approaching conflict," for which "nothing but the baptism of the Holy Spirit" would be able to prepare

${ }^{5}$ See pp. 61-62, 70 above.

${ }^{6}$ Ellen G. White, “The Need of Self-Surrender,” MS 148, October 8, 1899, published, in part, in Manuscript Releases: From the Files of the Letters and Manuscripts Written by Ellen G. White, 21 vols. (Silver Spring, MD: E. G. White Estate, 1981-1993), $1: 370$. 
believers. ${ }^{7}$ Likewise, in a June 1889 sermon in Rome, New York, White exhorted believers to "be prepared for the time of trouble such as never was since there was a nation."8

In the context of the emphasis on righteousness by faith during these post-1888 years, it is significant that Ellen White gave emphasis to the fact that "it is only in Christ that we can meet" "the powers of darkness," and that "God has opened to us our strength," "Christ our righteousness." 9 The thrust of her message in this sermon on "Christ and the Law" is that Christ did not do away with the law, but that when He enters the heart of those who repent He enables them to obey. In a telling paragraph, she decries those who take up Paul's lament in Rom 7:21, that when he tried to do good, he found that only evil was present with him:

There are to be trying times before us, and what does God mean? He means that we seek to understand what He wants to say to us. We have not understood it; we have been going on here, groaning and groaning. When I tried to do good, evil was present with me and sin is constantly at work to have the supremacy. If you could see what Christ is, one that can save to the uttermost all that come unto God by Him, then you would have that faith that works. ${ }^{10}$

${ }^{7}$ Ellen G. White to Dr. Burke, December 20, 1889, Letter 15, 1889, published, in part, in Manuscript Releases: From the Files of the Letters and Manuscripts Written by Ellen G. White, 21 vols. (Silver Spring, MD: E. G. White Estate, 1981-1993), 2:30.

${ }^{8}$ Ellen G. White, "Christ and the Law," MS 5, 1889, sermon given at Rome, NY, June 19, 1889, published in Ellen G. White, Sermons and Talks (Silver Spring, MD: E. G. White Estate, 1990-1994), 1:115.

${ }^{9}$ Ibid.

${ }^{10}$ Ibid., 1:111. 
However, she also warned against the "self-sufficiency" that she saw among believers, who needed rather to be "hid with Christ."

\section{Translation at Christ's Appearing}

The translation of believers into Christ's kingdom at His coming is the culmination of last-day events for which Ellen White urges preparation. As she made clear many times, especially after the 1888 General Conference session, a great work of

crucifying self is seen to be needed before believers are ready for translation. ${ }^{12}$ Also, as in earlier years, she maintains the necessity of character perfection on the part of the believer in order to be ready for translation. For instance, in an 1894 Youth's Instructor article, she pleads, "May the Lord help us to make a success of perfecting Christian character, that we may be fitted for translation to heaven." ${ }^{\prime 13}$

In order to be ready to enter the kingdom of heaven, White points out the necessity of having on the spotless robe of Christ's righteousness. Speaking at the 1903 General Conference session, she asks the delegates:

Suppose that today Christ should appear in the clouds of heaven, who of this congregation would be ready to meet Him? Suppose we should be translated into the kingdom of heaven just as we are. Would we be prepared to unite with the saints of God, to live in harmony with the royal family, the children of the heavenly King? ...

${ }^{11}$ Ibid., 1:114.

${ }^{12}$ Ellen G. White, "Issues at the Gen. Conf. Of 1889," MS 6, November 4, 1889 , published in The Ellen G. White 1888 Materials (Washington, DC: E. G. White Estate, 1987), 493.

${ }^{13}$ Ellen G. White, "Words to the Young," Youth's Instructor, September 6, 1894, 285. See also idem, "Be Ye Therefore Perfect," MS 157, 1898, published, in part, in Manuscript Releases: From the Files of the Letters and Manuscripts Written by Ellen G. White, 21 vols. (Silver Spring, MD: E. G. White Estate, 1981-1993), 6:5. 
... How many of us have on the wedding-garment? How many of us are without spot or wrinkle or any such thing? ${ }^{14}$

She repeats the idea in a sermon three years later at the Oakland, California, church, summing up: "While probation still lingers, every soul ought to be washing his own robe of character, and preparing for translation.." ${ }^{15}$ At the end of this discourse, she prayed earnestly that her hearers would realize what was necessary for translation: "Thou alone canst impress the understanding with a realization of the character that every soul must have and reveal in this world before he can be prepared for translation into the family of heaven." She laments over the "terrible blindness, that comes over the people, that they do not discern what manner of character Thou canst accept and what Thou wilt be compelled to reject!" ${ }^{\prime 16}$ From this fervent prayer comes a rather pronounced insight into White's concept of the character transformation necessary prior to translation.

While it seems clear that Ellen White understood character perfection to be a prerequisite for translation, she also warned of the error of those who claimed they were perfect. In 1901 a number of minsters in Indiana were promoting the idea that believers must possess holy flesh, such as they understood Christ to have, in order to be ready for

${ }^{14}$ Ellen G. White, "A Call to Repentance: Talk by Mrs. E. G. White, Sabbath, April 4, 11 A.M.," General Conference Bulletin, April 6, 1903, 88-89. In a 1909 sermon she proclaimed, "If we are translated, we shall be translated just as we are. We are to be made perfect in this life." Idem, "Two Kinds of Service," Review and Herald, March 25, 1909,8 .

${ }^{15}$ Ellen G. White, "Lessons from the Fifteenth of Romans," 1906, sermon preached by E. G. White at the Congregational Church, which was being temporarily used by the Oakland SDA Church, 18th and Market Streets, Oakland, California, on Sabbath afternoon, October 20, 1906, published in Ellen G. White, Sermons and Talks (Silver Spring, MD: E. G. White Estate, 1990-1994), 1:371.

$$
{ }^{16} \text { Ibid., } 379 .
$$


translation. She sharply rebuked the leaders of this movement, recalling fanatical movements early in her ministry, in which some "declared that they were perfected, that body, soul, and spirit were holy.... They declared that as their flesh was purified, they were ready for translation." ${ }^{17}$ Apparently, she understood a perfect character to be something quite different from perfect flesh, or a sinless nature.

\section{Perfection of the Church}

From what has been reviewed in the previous section, it may seem unnecessary to examine further Ellen White's post-1888 understanding of the perfection of the end-time church. But as this point is critical to this particular study, more attention will here be given to a few related points. One is the spotless robe of righteousness that believers must wear: Is it imputed or imparted, or both? Another point to be further examined is how White addresses the question of the possibility of character perfection. And especially appropriate for this study of final-generation concepts is the eschatological significance of the perfection of the church in White's estimation.

\section{The Robe of Righteousness}

Imputed or imparted?

Having seen how Ellen White stresses the need to develop perfect characters in order to be ready for translation, one would think that what is conveyed by words such as "[having] on the wedding garment," being "without spot or wrinkle or any such thing,"

${ }^{17}$ Ellen G. White, "Regarding the Late Movement in Indiana: Article Read by Mrs. E. G. White before the Ministers, April 17, 1901," General Conference Bulletin, April 23, 1901, 420. See pp. 166-169 below regarding the "holy flesh" movement. 
and being clothed "with the robe of Christ's righteousness," would be obvious. ${ }^{18}$ Twice in 1891 she speaks of a "washing of the robes of character."19 "The washing of the robes of character must go on from day to day, that at last we may be found without spot or wrinkle or any such thing, but blameless before Him with whom we have to do."${ }^{, 20}$ And in a 1901 Signs of the Times article that urges all to prepare for the soon coming of Christ, she even speaks of "a time in which to wash and iron our garments of character, that we may appear before Christ without spot or wrinkle or any such thing.".21

Though it seems plain that she is speaking of the robe of righteousness as imparted righteousness, in the sense of obedience, her use of the term does not fit nicely into the usual categories of "imputed" and "imparted" that theologians use to clarify the way that righteousness is applied to the believer in Christ. To be sure, in some passages White does clarify the terms theologically. For instance, in an 1895 Review article, she succinctly distinguishes imputed from imparted righteousness: "The righteousness by which we are justified is imputed; the righteousness by which we are sanctified is imparted. The first is our title to heaven, the second is our fitness for heaven." ${ }^{22}$ And in an 1894 Youth's Instructor article, White declares, "To those who believe in Christ as

${ }^{18}$ E. G. White, “A Call to Repentance,” 89; idem, “'Lessons from the Fifteenth of Romans," Sermons and Talks," 371.

${ }^{19}$ E. G. White, “"What Shall We Do?,"” 242; idem, "Faithful in Little," Signs of the Times, May 25, 1891, 165 (5).

${ }^{20}$ E. G. White, "Faithful in Little," 165 (5).

${ }^{21}$ Ellen G. White, "The Days of the Son of Man," Signs of the Times, April 17, 1901, 3 (243).

${ }^{22}$ Ellen G. White, "Qualifications for the Worker," Advent Review and Sabbath Herald, June 4, 1895, 353 (1). 
their personal Saviour, he imputes his merit and imparts his power."23

However, there are other passages in which it is not as easy to grasp a clear separation between the two concepts. For example, in an 1898 Signs article, White uses the word "imputed" where one might expect her more properly to use "imparted": "Through the imputed righteousness of Christ, all who receive Him by faith can show their loyalty by keeping the law." ${ }^{24}$ Furthermore, this passage is set in an article dealing with the Sabbath question and the need to keep the law, in which White points out that Christ came to falsify "Satan's charge that human beings cannot keep the law of God." 25 Likewise, in a letter written the next year, she seems to mix concepts of imputed and imparted righteousness:

We can be saved only by forming characters like the character of Christ. The indwelling of the Holy Spirit will be shown by the outflowing of heavenly love. The Lord Jesus is our Sinbearer. God covers the repenting sinner with His forgiveness, and hides the sin from the sight of God by clothing him with the perfection of righteousness. The more perfectly we are transformed to the image of God, the greater will be our hatred for sin; and we will work to save the sinner. ${ }^{26}$

Thus, the concept of the repentant sinner being clothed with the sin-hiding, perfect robe of righteousness is blended with the need of forming Christlike characters and being transformed into God's image. 261.

${ }^{23}$ Ellen G. White, “'A Man among Men,"” Youth's Instructor, August 16, 1894,

${ }^{24}$ Ellen G. White, “The Sabbath of the Lord, No. 2," Signs of the Times, April 7, 1898, 3 (211).

${ }^{25}$ Ibid.

${ }^{26}$ Ellen G. White to Philip Wessels, February 3, 1899, Letter 20, 1899, published, in part, in Manuscript Releases: From the Files of the Letters and Manuscripts Written by Ellen G. White, 21 vols. (Silver Spring, MD: E. G. White Estate, 1981-1993), 2:12. 
This joining of what theologians would tend to differentiate- forensic and experiential righteousness - is also seen in a 1901 Review and Herald article on obedience, in which, having shown that "perfect obedience to the law" is the continuing qualification for life, White points out that "righteousness without a blemish can be obtained only through the imputed righteousness of Christ." But what she means by this is clarified in the following sentence: "Through the provision that God has made for the forgiveness and restoration of sinners, the same requirements may be fulfilled by men today that were given to Adam in Eden." ${ }^{27}$ Thus one must be careful not to automatically understand "imputed" in Ellen White's writings in the forensic, legal sense only.

From such passages one might be inclined to believe that Ellen White lacked a full understanding of justification and imputation of merit. But in an earlier Signs article (1892) entitled "Accepted in Christ," she makes clear the benefits of Christ's imputed righteousness: "However sinful has been [the penitent sinner's] life, if he believes in Jesus as his personal Saviour, he stands before God in the spotless robes of Christ's imputed righteousness.... Who can comprehend the nature of that righteousness which makes the believing sinner whole, presenting him to God without spot or wrinkle or any such thing?"28 And there is no reference to overcoming or character perfection in this context. It is a clear proclamation, rather, of justification:

Perfection through our own good works we can never attain. The soul who sees Jesus by faith, repudiates his own righteousness. ...

... In looking to ourselves for righteousness, by which to find acceptance with

\footnotetext{
${ }^{27}$ Ellen G. White, "Obedience the Fruit of Union with Christ - No. 2," Advent Review and Sabbath Herald, September 3, 1901, 567 (1).

${ }^{28}$ Ellen G. White, “Accepted in Christ," Signs of the Times, July 4, 1892, 534 (6).
} 
God, we look to the wrong place, "for all have sinned, and come short of the glory of God." ... .

Standing before the broken law of God, the sinner cannot cleanse himself; but, believing in Christ, he is the object of his infinite love and clothed in his spotless righteousness. $^{29}$

Such a powerful description of the justifying efficacy of the robe of righteousness seems to give a completely different impression of this robe of righteousness than the passages quoted previously that present the necessity of washing out spots and ironing wrinkles. ${ }^{30}$ And the seeming discrepancy cannot be completely explained by the fact that the 1892 article extolling the benefits of justification is so near in time to the 1888 General Conference session, since urgent calls for character transformation also arose close to this time. $^{31}$

Joshua and the Angel

As seen in chapter 2 of this study, ${ }^{32}$ Ellen White began in 1885 to draw attention to the vision of Joshua, the high priest, and the Angel of the Lord found in the book of Zechariah (3:1-5). It was noted in the discussion in chapter 2 that White understood this experience to be what believers were to undergo at the end of time- - whether during the sealing time before the close of probation or during the time of trouble after the close of probation. ${ }^{33}$ In the context of this discussion of the robe of righteousness, it may be

${ }^{29}$ Ibid. $165(5)$.

${ }^{30}$ E. G. White, "The Days of the Son of Man," 3 (243); idem, "Faithful in Little,"

${ }^{31}$ E. G. White, "Words to the Young," 285; idem, "Faithful in Little," 165 (5).

${ }^{32}$ See pp. $79-83$ above.

${ }^{33}$ See p. $80-81$ above. 
helpful to review what White had to say about this in the post-1888 period.

Unlike her earlier statements from before 1888, which seemed to interpret the robe of righteousness experientially,${ }^{34}$ in the post-1888 era she seems to focus more on imputed righteousness. The change of clothing that Joshua undergoes is interpreted by White, in a manuscript written in 1901, as a blotting out, or covering, of sins, and an imputation of Christ's righteousness. After the change Joshua stands "clothed with the imputed righteousness of Christ. ${ }^{35}$ Similarly, in an 1893 Review article, she interprets Joshua as a representative of God's true people, whom Satan accuses as sinners. With the change of clothing, their sins were forgiven, "and they stood before God as chosen and true, as innocent, as perfect, as though they had never sinned. ... However weak and compassed with infirmity the people of God may be, ... through the righteousness of Christ [they] will stand perfect before God." ${ }^{\prime 36}$ This unmistakable description of the condition of the believer who has been justified by the imputed righteousness of Christ harmonizes with the statements examined previously from her 1892 Review article, "Accepted in Christ." 37

In subsequent years White continued to refer to Joshua and the Angel, and her related commentary provides helpful insights into her understanding of the situation of

${ }^{34}$ See pp. $79-80,82$ above.

${ }^{35}$ Ellen G. White, MS 125, 1901, published, in part, in Francis D. Nichol, ed., The Seventh-day Adventist Bible Commentary: The Holy Bible with Exegetical and Expository Comment, 7 vols. (Washington, DC: Review and Herald, 1953-1957), 4:1178.

${ }^{36}$ Ellen G. White, "The Remnant Church Not Babylon (Continued)," Advent Review and Sabbath Herald, August 29, 1893, 546 (2).

${ }^{37}$ E. G. White, “Accepted in Christ,” 534 (6). See pp. 127-128 above. 
the final generation of believers. In an 1894 manuscript she describes Satan's charges against God's tempted ones as "malignant," "[painting] them in robes of blackness and moral defilement. ${ }^{338}$ Similarly, in a message to the delegates at the 1901 General Conference, she describes Satan presenting believers in a "questionable light, as those who are clothed with filthy garments. God says, 'Take away the filthy garments. You have no right to put them upon them. Take them away. My people may have imperfections of character. They may fail in their endeavors, but if they repent, I will forgive them." ${ }^{\prime 39}$ Here White portrays God admitting the possibility that His people might have imperfect characters, and that they might fail and need to ask for forgiveness. This could be taken to indicate that she was open to the possibility, or even convinced, that the final generation would not achieve the goal of character perfection.

One further exhibit may help to shed light on the question: To what extent did Ellen White understand the vision of Joshua and the Angel to apply to end-time believers? A full-length article treating the prophecy of Zech 3 appeared in the September 22, 1896, Review and Herald under the title, "Our Advocate and Our Adversary." ${ }^{40}$ Here again White portrays Satan trying to cover believers "with blackness, and ruin them." Then, she says, Jesus interposed and "snatched the race as a brand from the fire." Two paragraphs later, she states that Jesus will not abandon His people

${ }^{38}$ Ellen G. White, Manuscript 27, 1894, published, in part, in Ellen G. White, Christ Triumphant (Hagerstown, MD: Review and Herald, 1999), 186.

${ }^{39}$ Ellen G. White, "His Wonderful Love: Mrs. E. G. White, Sabbath, April 20," General Conference Bulletin, April 23, 1901, 423.

${ }^{40}$ Ellen G. White, "Our Advocate and Our Adversary," Advent Review and Sabbath Herald, September 22, 1896, 597-598 (1-2). 
"notwithstanding the defects of the people of God ever since the fall." He places "his robe of righteousness" on repentant sinners, pardoning them. ${ }^{41}$ Language like "snatch the [human] race" and "defects ... ever since the fall" seem to give a rather broad interpretation to the vision of Joshua and the Angel, applying it to Christ's mediatorial work in all history. But in the next paragraph, declaring that Satan's accusatory work began in heaven and has been kept up "ever since the fall," White points out that "it will be his work in a special sense as we approach nearer to the close of time. ${ }^{.42}$ And the last paragraph of the article begins by declaring, "But there is a more important feature in this lesson. Its full meaning will be experienced by those who shall be alive at the coming of the Lord." ${ }^{43}$ So, as in her previous discussions, this prophecy is applied especially to the final generation.

A question that was left unanswered in White's 1885 treatment of Zechariah's vision is: Does the change of clothing occur before or after the close of probation? It was noted in chapter 2 that the language White uses in connection with describing end-time fulfillments of this prophecy seems to extend it to the time of Jacob's trouble, while she explicitly states that the prophecy especially applies to the time of the sealing, during the "closing up of the great day of atonement."44 It might appear from this that by the 1880 s White's end-time schematic map, which seemed so clear in the late 1840s and early

\footnotetext{
${ }^{41}$ Ibid., 597 (1).

${ }^{42}$ Ibid.

${ }^{43}$ Ibid., 598 (2).

${ }^{44}$ E. G. White, Testimonies, 5:472. See discussion of this on pp. 80-83 above.
} 
1850s, was beginning to become blurred. However, in her 1896 article, she seems to put to rest possible notions of ongoing intercession and mediation during the time of Jacob's trouble: "The time that will try men's souls is just before us. We shall then have no advocate to rebuke the devil, and plead in our behalf. Every soul must resist the discouragement that Satan will surely suggest, that our sins are too many and too grievous to be pardoned." ${ }^{45}$ And the last paragraph of the article gives strong indications that the struggle for the last-generation believers at the end will be to maintain their confidence in God, just as Jesus had to do when facing Satan's "if" temptations: "They will know the fellowship of Christ's sufferings. Satan's malignity will be intensified toward them, as he sees that his time is short. ... We must have Christ dwelling in our hearts by faith. 'If' is the temptation that strikes against Jesus. In fullest confidence we must accept Jesus as our Saviour. ${ }^{~} 46$ Apparently the removing of the filthy garments, and the clothing of the saints with the robe of Christ's righteousness, with the rebuke of the devil by Christ, the sinner's Advocate, takes place only while Christ continues His mediatorial work before probation's close. Whether the righteousness is imparted or imputed, it must be applied to sinners while their Advocate is still at work.

\footnotetext{
${ }^{45}$ E. G. White, "Our Advocate and Our Adversary," 598 (2). Cf. the 1885 statements: "As Joshua was pleading before the Angel, so the remnant church, with brokenness of heart and earnest faith, will plead for pardon and deliverance through Jesus their Advocate. ... They have put away their sins, and have sought the Lord in humility and contrition, and the divine Advocate pleads in their behalf." Idem, Testimonies, 5:473474 .
}

${ }^{46}$ E. G. White, “Our Advocate and Our Adversary," 598 (2). 


\section{Character Perfection and the End of Time}

The robe of righteousness that is provided God's end-time saints is thus seen by Ellen White to be provided before probation closes. Though from the above study a case can be made that this primarily signifies the imputed righteousness of Christ that covers the defects and imperfections of believers, there are many passages from White's later writings that indicate her retention of the expectation of character perfection by the lastday believers. This section will give attention to the question of White's post-1888 view of the possibility of character perfection, the process and end-product of perfection, and the significance of perfection at the end of time. Though these points had been made in previous years, it is significant that they remained intact over her long writing career.

Possible or impossible?

The question of the possibility of character perfection by fallen humans is one that Ellen White addressed very clearly and pointedly. Obedience and perfection were closely related to Adventist views of the relationship between the law and the gospel, and the end-time significance of the Sabbath.

No softening on the requirement. If anything, White was not ambiguous about the necessity of character perfection, including in the post-1888 era (though not immediately after the 1888 General Conference session-most of the references in this section are from the late 1890 s and early 1900s). In a manuscript written in 1901, White asks what the Bible means by Christ presenting the church to Himself without spot or wrinkle. Her answer is simple: "It means that God's people can and must reach the 
standard of Christian perfection. ${ }^{\circ 47}$ Again, in a letter written to a group of believers in 1905 counseling Christlikeness in treating erring members, she states, "No unlikeness to Christ will be permitted in the holy city.... The process of gaining perfection of character is to be carried on in this life, that we may be prepared for the future immortal life. It is God's purpose that His church on earth shall reach perfection." ${ }^{\$ 48}$ In a 1901 Youth's Instructor article, she made clear that "one defect, cultivated instead of being overcome, makes the man imperfect, and closes against him the gate of the Holy City. He who enters heaven must have a character that is without spot or wrinkle or any such thing. Naught that defileth can ever enter there. In all the redeemed host not one defect will be seen." ${ }^{49}$

Doubts, denials, excuses. White's position on the attainability of this standard is also clear. She argues forcefully against the idea that perfection of character is an impossible attainment. In a 1901 testimony to the Battle Creek church, she maintains that, though the standard is beyond our comprehension, it is attainable through Christ. "The standard of character which Christ has made it possible for us to reach ... is a perfect standard. In trying to measure [up to] it, the senses become confused.... The

${ }^{47}$ Ellen G. White, "God's Holy Law, the Unchanging Standard," MS 73, 1901, published in Manuscript Releases: From the Files of the Letters and Manuscripts Written by Ellen G. White, 21 vols. (Silver Spring, MD: E. G. White Estate, 1981-1993), 14:351.

${ }^{48}$ Ellen G. White, St. Helena, CA, to Brethren and Sisters, February 18, 1905, Letter 67, 1905, published, in part, in Manuscript Releases: From the Files of the Letters and Manuscripts Written by Ellen G. White, 21 vols. (Silver Spring, MD: E. G. White Estate, 1981-1993), 15:171. $17,1901,1$.

${ }^{49}$ Ellen G. White, "Faithful in That Which Is Least," Youth's Instructor, January 
question is asked, 'Who by searching can find out God?' (See Job 11:7.) Yet He has made it possible for us to become like Him in character." ${ }^{50}$

White argues rather forcefully against those who deny the possibility of complete obedience. She links such sentiments to Satan's charge against the law at the beginning stages of the controversy between good and evil. In a 1903 message "to medical missionaries" White wrote that Christ came to "prove the falsity of the charge made by Satan that it is impossible for man to keep the law of God.... His life testifies that it is possible for us also to obey the law of God." ${ }^{51}$ And in her 1899 manuscript entitled "The Need of Self-Surrender" she laid out the implications of a denial of the possibility of living a "perfect life": "Exact obedience is required, and those who say that it is not possible to live a perfect life throw upon God the imputation of injustice and untruth." ${ }^{.52}$ Again, in an 1897 manuscript White sees no reason for believers to retain "the frailty and imperfection of humanity." Whoever does not believe that Christ "can keep him from sinning, has not the faith that will give him an entrance into the kingdom of God."53

${ }^{50}$ Ellen G. White, "Testimony to the Battle Creek Church," MS 16, February 25, 1901, published, in part, in Ellen G. White, The Upward Look (Washington, DC: Review and Herald, 1982), 70. In the second sentence of this quotation, the compilers of this devotional volume insert "up to," which is grammatically unnecessary, and actually quite misleading. Though we are not given all of the immediate context, the biblical context she is referencing helps make her meaning clear, i.e., the measure of God's perfection is past human comprehension, so that the senses are bewildered in attempting to grasp it: "The measure thereof is longer than the earth, and broader than the sea" (Job 11:9).

${ }^{51}$ E. G. White, Testimonies, 8:207-208.

${ }^{52}$ E. G. White, “'Need of Self-Surrender,” Manuscript Releases, 1:369.

${ }^{53}$ Ellen G. White, MS 161, 1897, published, in part, in Ellen G. White, Selected Messages, 3 vols. (Washington, DC: Review and Herald, 1958-1980), 3:360. 
White makes her arguments even more forcefully when she speaks in the context of the end-times and the judgment. An article in the Signs of the Times in 1901, entitled “"Be Ye Therefore Perfect," exhorts Christians to "aim at perfection." "No one should say, I can not do it. He should say instead, God requires me to be perfect, and He will give me strength to overcome all that stands in the way of perfection." And since Christ makes it possible for His followers to overcome, at His second advent, "He will ask us why we have not fulfilled His purpose for us. ${ }^{, 54}$ And in a talk given on a Sabbath during the 1888 General Conference session, she was very direct about the implications of the attitude which expresses doubt about one's ability to overcome:

Now, what we want to present is how you may advance in the divine life. We hear many excuses: I cannot live up to this or that. What do you mean by this or that? Do you mean that it was an imperfect sacrifice that was made for the fallen race upon Calvary, that there is not sufficient grace and power granted us that we may work away from our own natural defects and tendencies, that it was not a whole Saviour that was given us? or do you mean to cast reproach upon God? Well, you say, it was Adam's sin. You say, I am not guilty of that, and I am not responsible for his guilt and fall. Here all these natural tendencies are in me, and I am not to blame if I act out these natural tendencies. Who is to blame? Is God? Why did God let Satan have this power over human nature? These are accusations against the God of heaven, and $\mathrm{He}$ will give you an opportunity, if you want it, of finally bringing your accusations against Him. Then He will bring His accusations against you when you are brought into His court of judgment. ${ }^{55}$

However, even in this talk, she speaks of the righteousness of Christ being imputed to repentant sinners, or even the human race: Christ "imputes to me His righteousness"; "the righteousness of Christ was brought in and imputed to [man] that he might be brought 3 (451).

${ }^{54}$ Ellen G. White, “'Be Ye Therefore Perfect,”" Signs of the Times, July 17, 1901,

${ }^{55}$ Ellen G. White, “Advancing in Christian Experience," MS 8, 1888, Minneapolis General Conference, Sabbath, October 20, 1888, published in The Ellen G. White 1888 Materials (Washington, DC: E. G. White Estate, 1987), 122. 
back to his loyalty to God"; you must believe that Christ "imputes to you His

righteousness. ${ }^{" 56}$ So there is a balance between the imputed and the imparted aspects of righteousness in her message.

As Christ overcame. White lifts up Christ in this period as the way to overcome. In a presentation given in 1891, she asks, "Shall we keep on sinning as though it were an impossibility for us to overcome? How are we to overcome? As Christ overcame." ${ }^{57}$ And in an 1898 manuscript, in answer to the question how believers can attain to the high standard, she answers, "The required perfection is based on the perfection of Christ. In Him is our righteousness. ${ }^{958}$ In a letter to workers in Australia the next year, she points out that Christ wants to walk with believers and "teach them how He overcame every temptation in humanity, and how, therefore, they may overcome through the provision the Lord has made.... In their fallen nature people can do the very things God expects them to do through the help provided for them." 59 And when White's full version of the life of Christ, The Desire of Ages, was published in 1898, she expanded what she had written in The Great Controversy ten years earlier regarding the correspondence between the overcoming of Christ and the believer. Describing the temptations of Christ afer His

${ }^{56}$ Ibid., 125, 127-128.

${ }^{57}$ Ellen G. White, “The Importance of Exercising Faith,” MS 83, 1891, A talk presented at Harbor Heights, Michigan, July 22, 1891, published in Ellen G. White, Sermons and Talks (Silver Spring, MD: E. G. White Estate, 1990-1994), 1:153.

${ }^{58}$ E. G. White, ““Be Ye Therefore Perfect,” Manuscript Releases, 6:5.

${ }^{59}$ Ellen G. White to [Dear Brethren Colcord, Starr, and Hickox], [November 29], 1899, Letter 195, 1899, published, in part, in Christ Triumphant (Hagerstown, MD: Review and Herald, 1999), 53. 
baptism, White declares that just as Satan could find nothing in Christ that responded to temptation — "not even by a thought" did He yield — "so it may be with us." The secret is "the indwelling of the Holy Spirit." By being "partakers of the divine nature" "we may attain to perfection of character. ${ }^{960}$

However, though White clearly states that believers can overcome as Christ did, she does not automatically shine the spotlight on believers' overcoming for the purpose of God's end-time vindication. In 1893, she had made it clear that Christ's life is the "unanswerable argument" which proves "that the law can be kept," and vindicates "God's justice in demanding that it be obeyed." ${ }^{61}$ Thus, while White is unambiguous about the possibility and expectation of character perfection through Christ, the passages studied do not make the vindication of God's law dependent on this.

Reflecting the divine image

Just as in earlier years, during the post- 1888 period Ellen White wrote of a process of character perfection that would eventuate in a clear reflection of God's glory by His people. In connection with reflecting God's image, White spoke twice of the 144,000 in the two or three months after the 1888 conference. In a sermon in December 1888 she emphasized the transformation of character when a believer becomes a partaker "of the divine nature" and displays "the image of Christ reflected," referring to the 144,000 as

${ }^{60} \mathrm{E}$. G. White, Desire of Ages, 123. Cf. the use of John 14:30 ("The prince of this world cometh, and hath nothing in Me") in idem, Great Controversy, 623.

${ }^{61}$ Ellen G. White, Manuscript 38, 1893, published, in part, in Ellen G. White, In Heavenly Places (Washington, DC: Review and Herald, 1967), 38. 
having "Christ formed within them the hope of glory." ${ }^{32}$ Similarly, in a January 1889 talk, she mentioned that this group "reflected the image of God."63

A process of polishing. Ellen White taught that this transformation takes place by a process of "polishing." She states in a 1902 manuscript dealing with evil-speaking, "Everyone who is pronounced worthy of a place in the Lord's temple must submit to the polishing process. He must consent to have the sharp edges cut away from his character, that it may be shapely and beautiful, fitted to represent the perfection of Christ's character. ${ }^{" 64}$ And in an 1894 letter to leaders at the Review and Herald office, she points out that "the Holy Spirit implants a new nature, and molds through the grace of Christ the human character, until the image of Christ is perfected." ${ }^{95}$ White's most explicit statement of the post-1888 era regarding this goal-driven process of polishing the image of Christ in believers appears in Christ's Object Lessons, published in 1900. Commenting on the parable of Mark 4:26-29, White interprets the harvest of the mature

${ }^{62}$ Ellen G. White, “The Minister's Relationship to God's Word,” MS 13, 1888, A sermon preached in the Seventh-day Adventist Church, Des Moines, IA, December 1, 1888, published in Ellen G. White, Sermons and Talks (Silver Spring, MD: E. G. White Estate, 1990-1994), 63, 72-73.

${ }^{63}$ Ellen G. White, "Is It Well with My Soul?" Advent Review and Sabbath Herald, March 19, 1889, 177 (1).

${ }^{64}$ Ellen G. White, “The Sin of Evilspeaking," MS 168, 1902, published in Manuscript Releases: From the Files of the Letters and Manuscripts Written by Ellen G. White, 21 vols. (Silver Spring, MD: E. G. White Estate, 1981-1993), 18:202.

${ }^{65}$ Ellen G. White to Brethren in Responsible Positions in the Review and Herald Office, January 13, 1894, Letter 70, 1894, published, in part, in Manuscript Releases: From the Files of the Letters and Manuscripts Written by Ellen G. White, 21 vols. (Silver Spring, MD: E. G. White Estate, 1981-1993), 2:12-13. 
plant as the coming of Christ after the character of Christ is "perfectly reproduced." "Christ is seeking to reproduce Himself in the hearts of men.... Christ is waiting with longing desire for the manifestation of Himself in His church. When the character of Christ shall be perfectly reproduced in His people, then He will come to claim them as His own." ${ }^{96}$ Thus White assigns eschatological significance to the perfecting of believers, which is expressed even more positively in the next sentence, "It is the privilege of every Christian not only to look for but to hasten the coming of our Lord Jesus Christ. ${ }^{967}$

The standard of measurement. The end product of this process of polishing, according to Ellen White, is a perfect reflection of the divine image. As noted above, she emphasizes that the perfect standard of character is so high that "in trying to measure it, the senses become confused. ${ }^{968}$ In an 1897 Signs of the Times article on the life of Christ, White proclaims that the "same love" that Christ revealed "is to be revealed" in humanity. "In the fallen race the very image of God is to be reflected. ... The honor of Christ must stand complete in the perfection of the character of his chosen people. ${ }^{969}$ As she writes in a letter in 1893, this restoration of the divine image in fallen humanity "will prove the counteracting of Satan's ingenious work to ruin man." It is nothing less than "re-

${ }^{66}$ Ellen G. White, Christ's Object Lessons (Washington, DC: Review and Herald, 1941), 67-69.

${ }^{67}$ Ibid., 69.

${ }^{68}$ E. G. White, "Testimony to the Battle Creek Church," 70. The misleading editorial insertion in the published version has been deleted here, restoring what is most likely the original sense. See p. 135 n. 50 above.

${ }^{69}$ Ellen G. White, "Farewell Words (Concluded): The Peace of Christ," Signs of the Times, November 25, 1897, 5 (725). 
creation ...; ; a clean thing is brought out of an unclean, restoring the image of God in man. The human agent is to go forward to reach the highest standard of perfection of character by beholding the character of Jesus Christ." ${ }^{, 70}$

Eschatological significance

Though from what has been observed here it seems clear that Ellen White understood character transformation to be critical for believers awaiting the return of Jesus, the question still remains as to what, if any, role she understood this process, or its end product, to play in the conflict between good and evil at the end. One reason for this is that White stressed the need for perfect obedience to the law, not as a special condition needed only for those expecting translation, but as a universal requirement for all the saved. An article on obedience published in 1901 makes this clear: "From Genesis to Revelation the conditions upon which eternal life is promised, are made plain. God requires that those who shall enter heaven shall be without spot or wrinkle or any such thing."ㄱ1

And as before ${ }^{72}$ she continued in the post-1888 era to maintain that character perfection was necessary specifically for the resurrection to eternal life, as well as for

${ }^{70}$ Ellen G. White to Edgar Caro, October 2, 1893, Letter 17a, 1893, published, in part, in Manuscript Releases: From the Files of the Letters and Manuscripts Written by Ellen G. White, 21 vols. (Silver Spring, MD: E. G. White Estate, 1981-1993), 7:274275.

${ }^{71}$ E. G. White, "Obedience the Fruit of Union with Christ - No. 2," 567 (1). See pp. 124-129 above for discussion of the mixing of forensic and experiential aspects of righteousness in this passage.

${ }^{72}$ See pp. 59-60 above. 
translation. In an 1891 Signs article, she maintained that "it is only the blessed and holy who will be ready for the first resurrection; for when Christ comes, he will not change the character. ... The word of God declares that we must be found blameless, without spot or wrinkle or any such thing." ${ }^{73}$ Thus, White does not portray perfection of character as a unique requirement for those preparing for translation. In view of the proximity of the date of this article to the 1888 focus on righteousness by faith, it is also interesting to note the very next sentences, limiting the role of human effort in the process of attaining perfection of character: "Now we are to learn obedience, submission to the divine will, that God may work in us to will and to do of his good-pleasure, and that we may work out our own salvation with fear and trembling. But our own efforts are of no avail to atone for sin or to renew the heart. Only the blood of Christ can atone for us; his grace alone can create in us a clean heart, and enable us to obey God's law. In him is our only hope. $" 74$

But there are some passages from this post-1888 period that lead one to believe that Ellen White saw the end-time generation of believers as having a pivotal role in the closing struggle between good and evil. As seen previously, White depicts Christ as "waiting with longing desire" for the maturation of His people. ${ }^{75}$ In other places she speaks of the honor of Christ being completed or supplemented by the "full and final" display of His character in His people. In a letter to the 1893 General Conference, White 1891, 44 (4).

${ }^{74}$ Ibid.

${ }^{75}$ E. G. White, Christ's Object Lessons, 69. See pp. 139-140 above. 
declared that "the church, being endowed with the righteousness of Christ, is his depository, in which the wealth of his mercy, his love, his grace, is to appear in full and final display." The previous paragraph tells how Christ is training His people in developing characters, "making experiments on human hearts," "effecting transformations so amazing that Satan" views them as "an incomprehensible mystery," and the angels of God "look on with astonishment and joy." She concludes the letter by pointing out that Christ's glory is supplemented by His perfected people: "In their untainted purity and spotless perfection Christ looks upon his people as the reward of all his suffering, his humiliation, and his love, and the supplement of his glory,-Christ the great center from which radiates all glory." ${ }^{976}$

As seen above, in her 1897 Signs of the Times article on Christ's last words to his disciples, White expresses similar ideas, when she says that "honor of Christ must stand complete in the perfection of the character of his chosen people. He desires that they shall represent his character to the world. ${ }^{.77}$ White combines both of these passages in the chapter, "'Let Not Your Heart Be Troubled,"” in her 1898 Desire of Ages:

Christ has given His Spirit as a divine power to overcome all hereditary and cultivated tendencies to evil, and to impress His own character upon His church.

... The very image of God is to be reproduced in humanity. The honor of God, the honor of Christ, is involved in the perfection of the character of His people....

... In His people He is glorified. Through them the Sun of Righteousness will shine in undimmed luster to the world. ... The church, endowed with the righteousness of Christ, is His depositary, in which the riches of His mercy, His grace, and His love, are to appear in full and final display. Christ looks upon His people in their purity and perfection, as the reward of His humiliation, and the supplement of

\footnotetext{
${ }^{76}$ Ellen G. White, "Dear Brethren of the General Conference," Daily Bulletin of the General Conference, February 27, 1893, 408-409.

${ }^{77}$ E. G. White, "Farewell Words (Concluded): The Peace of Christ," 5 (725).
} 
His glory, - Christ, the great Center, from whom radiates all glory. ${ }^{78}$

White thus expands and broadens the idea that was seen in her comment in 1878 , in the third volume of The Spirit of Prophecy, that the church carries "to glorious perfection the work which [Christ] has commenced." Christian history as driving towards a well-defined goal. From this review of Ellen White's relevant statements at the culmination of her writing career, it seems clear that she held a concept of a mature church at the end of time that would amaze the universe, and supplement and complete the manifestation of God's love as seen in the life of Christ.

\section{End-time Vindication of God}

A question that remains is whether and how this end-time manifestation of Christ's character in His people is related to the end-time vindication of God in the ongoing cosmic struggle, which was brought to light in Ellen White's earlier writings. ${ }^{80}$ White continued to present the story of salvation history in the context of Satan's fall from heaven and his original charges against God's justice. Near the close of her life of Christ, Desire of Ages, she identifies two charges that Satan had made at the beginning of the conflict: "It was proved, he claimed, that the law could not be obeyed; man could not

\footnotetext{
${ }^{78}$ E. G. White, Desire of Ages, 671, 680.

${ }^{79}$ E. G. White, Spirit of Prophecy, 3:261.

${ }^{80}$ See pp. $72-76,85-89$ above.
} 
be forgiven." ${ }^{\prime 11}$ Both charges are refuted independently of, and also in connection with, the end-time generation of believers.

\section{Can the Law Be Obeyed?}

It has already been noted that White points out the implied charge of God's unfairness by "those who say that it is not possible to live a perfect life." 82 To say that one cannot live up to what is required because of one's natural tendencies is to "cast reproach on God." These "accusations against the God of heaven" will be thrown back on the sinner in the "court of judgment," according to White..$^{83}$

To these charges against the justice of God's law, White in the post-1888 era presented Christ as God's answer. By living "a life of obedience to its requirements," Christ proved the charges false and fulfilled His purpose in coming to earth "to vindicate the sacred claims of the law." ${ }^{\prime 4}$ Even in the judgment, Christ's obedience "while possessing the nature of man" "will be an unanswerable argument in favor of God's law," "vindicating God's justice in demanding that it be obeyed," proving "to the inhabitants of the unfallen worlds and to human beings that the law can be kept." 85 That Christ is an answer to these charges in the final judgment seems to obviate the need for further human evidence.

${ }^{81}$ E. G. White, Desire of Ages, 761.

${ }^{82}$ E. G. White, “'Need of Self-Surrender,” Manuscript Releases, 1:369.

${ }^{83}$ E. G. White, "Advancing in Christian Experience," 122. See p. 136 above.

${ }^{84}$ E. G. White, Testimonies, 8:207-208.

${ }^{85}$ E. G. White, MS 38, 1893, excerpt in In Heavenly Places, 38. 
Whether needed or not, White presents at least one more person chosen by God to falsify Satan's charge. In a 1900 manuscript, White names Enoch as a man whom God "selected ... to evidence to the world that it is possible for a person to keep all the law of God." "Now God would demonstrate to the universe the falsity of Satan's charge that human beings cannot keep God's law." However, this sentiment is not expressed explicitly in relation to the final generation, although elsewhere she clearly points to Enoch as a representative of the last generation of saints, who will live untouched by the corruptions surrounding them. ${ }^{87}$ What White does say, in connection with her 1893 exposition of Zechariah's vision of Joshua and the Angel, is that last-day believers will stand "to vindicate the holy law of God." But this is not necessarily by a track record of perfect overcoming, even though it seems she certainly expected them to finally attain to this state. Rather, these are people "who turn from disloyalty to God in this wicked and perverse generation, and come back to their allegiance," "however weak and compassed with infirmity [they] may be." It is "through the righteousness of Christ" that they "will stand perfect before God." 88

In 1901, Ellen White addressed a related charge of Satan's: Is the obedience of believers based on selfish motives? In the book Education, White points out lessons to be learned from Job's testing. She introduces the topic by providing biblical evidence

${ }^{86}$ Ellen G. White, MS 43, 1900, published, in part, under the title "Enoch Kept God's Law" in Ellen G. White, Christ Triumphant (Hagerstown, MD: Review and Herald, 1999), 51.

${ }^{87}$ See, for example, E. G. White, “Practical Remarks (Concluded),” 138.

${ }^{88}$ E. G. White, “The Remnant Church Not Babylon," 546 (2). As seen above, this is a passage that highlights imputed righteousness (p. 129). 
that believers are God's witnesses before the universe. Satan's charge is presented, made "from the beginning of the great controversy," that God and His followers act from selfish principles. White asserts that "to disprove Satan's claim is the work of Christ and of all who bear His name." Job is then examined as one "over whom this controversy of Satan's was waged. ${ }^{189}$ Thus White uses Job as an illustration of the role of believers as character witnesses in the great controversy, although there it is not clear from this passage that she understands the last generation to have a special or unique role in this respect. But when combined with other statements she made during this era with respect to a full and final display of God's love, it can be inferred that she anticipated a final demonstration of unselfishness on the part of believers as having a significant effect on the end-time progression of the controversy.

\section{Can Sinners Be Forgiven?}

The other charge made by Satan, according to White, was that God could not forgive the sinner. In an interesting article in the March 9, 1897, Review and Herald entitled "Christ Represents the Beneficence of the Law," she points out that "Satan charged God with an unforgiving spirit, because he would not receive on terms of favor those who disobeyed his law." The lack of "genuine repentance" on the part of the devil was the cause of his never experiencing God's forgiving love, and in turn he misrepresents God's character, according to White. To defeat this misrepresentation Christ came and in His life "represented the beneficence of the law." But witnesses are still to be presented to defeat charges that God is unmerciful. The goodness of the law "is

\footnotetext{
${ }^{89}$ Ellen G. White, Education (Mountain View, CA: Pacific Press, 1952), 154-155.
} 
to be testified before all nations, ... to worlds unfallen, to angels." A follower of Christ will "become an illustration of the divine law... Christ's true followers will be in conformity to the mind and will and character of God, and the far-reaching principles of the law will be demonstrated in humanity." 90

Just as with the first charge regarding the question of the possibility of perfect obedience, Christ is the supreme vindication of the depth of God's love and mercy. White made it clear in The Desire of Ages that by the cross "the love of God is manifested to the universe. The prince of this world is cast out. The accusations which Satan has brought against God are refuted. The reproach which he has cast upon heaven is forever removed." ${ }^{91}$ But against the final generation of believers White represents Satan as hurling vicious attacks, also, in an effort to invalidate God's mercy and forgiveness, apparently, as bestowed on those no more worthy than he.

In comments regarding the final generation of believers undergoing trial during the time of trouble, White characterizes their struggle as one of faith and confidence. In her 1890 Patriarchs and Prophets White compares Jacob's struggle with the Angel to the experience of believers passing through the "time of Jacob's trouble," with no mediation or atonement available for sin:

Such will be the experience of God's people in their final struggle with the powers of evil. God will test their faith, their perseverance, their confidence in His power to deliver them. Satan will endeavor to terrify them with the thought that their cases are hopeless; that their sins have been too great to receive pardon. They will have a deep

${ }^{90}$ Ellen G. White, "Christ Represents the Beneficence of the Law," Advent Review and Sabbath Herald, March 9, 1897, 145 (1).

${ }^{91}$ E. G. White, Desire of Ages, 626. 
sense of their shortcomings, and as they review their lives their hopes will sink. ${ }^{92}$ Again, in her 1894 manuscript dealing with Joshua and the Angel, she states that God "permits Satan to try and tempt and test His believing ones in order that their trust and confidence in God may be revealed." ${ }^{93}$ And in her 1901 General Conference presentation on the same subject, she portrays Satan as trying "to bring reproach against those who are trying to serve and honor God," who "may have imperfections of character" and "may fail in their endeavors." 94

The issue seems to be not whether the followers of Christ are spotless at this point, but whether they have changed allegiances. In the same 1897 passage in which White intimates that God will use the witness of believers to demonstrate the "principles of the law," she identifies those whom Satan accuses as those who throw off his yoke, "and come back to render willing allegiance to the God of heaven." Similar language is used in her 1893 Review article dealing with Joshua and the Angel. It is those who "turn from disloyalty to God" and "come back to their allegiance" who stand "to vindicate the holy law of God." "However weak and compassed with infirmity" they may be, "through the righteousness of Christ [they] will stand perfect before God."96 Thus it seems notable, in connection with the idea of vindication of God in the end-time, that White does not present believers' perfection of character. Rather, she points to their confidence and trust

${ }^{92}$ E. G. White, Patriarchs and Prophets, 202.

${ }^{93}$ E. G. White, “MS 27, 1894, in Christ Triumphant,” 186.

${ }^{94}$ E. G. White, "His Wonderful Love," 423.

${ }^{95}$ E. G. White, "Christ Represents the Beneficence of the Law," 145 (1).

${ }^{96}$ E. G. White, “The Remnant Church Not Babylon,” 546 (2). 
in God, faith that is not shaken despite their being confronted with their many failures, since these have all been confessed and forsaken. Though White is very clear that the standard of entrance into heaven is perfect obedience, when the spotlight is pointed at the end-time believers, this is not what is depicted in the struggle. Though they may have indeed attained to perfection of character at this point, and though this may contribute to the vindication of God in some degree, White does not seem to connect the ideas when she considers this end-time generation of believers.

\section{A. T. Jones and the Cleansing of the Sanctuary}

As one of the two chief proponents of righteousness by faith around and after the time of the 1888 General Conference session, Alonzo T. Jones was an influential voice in Adventism, especially in regard to end-time events. His influence was without doubt multiplied by Ellen White's endorsement of the message preached by himself and his fellow messenger of righteousness by faith, E. J. Waggoner. ${ }^{97}$ More than any other writer observed thus far in this study, Jones pushed forward the concept of the perfection of endtime believers in connection with the closing work of the sanctuary in heaven. Jones also must have had considerable influence on the development of the theological thought of M. L. Andreasen, as Andreasen relates that he and Jones, during the "whole summer" of

${ }^{97}$ She wrote to General Conference President O. A. Olsen in 1895: "The Lord in His great mercy sent a most precious message to His people through Elders Waggoner and Jones." Ellen G. White, Hobart, Tasmania, to O. A. Olsen, May 1, 1895, Letter 57, $1895,1336$. 
1899 "spent every Sunday on beautiful Lake Goguac in a rowboat discussing theology, and particularly the 1888 Conference."$" 98$

\section{Following Ellen White on Perfection}

Not only did Ellen White verbally endorse the message Jones and Waggoner preached around the time of the 1888 conference, she accompanied them as they traveled to different locations, preaching righteousness by faith to the Adventists. ${ }^{99}$ The sermons of Jones at the Ottawa, Kansas, camp meeting of 1889 were published in the Topeka Daily Capital. In his concluding message, entitled "Keeping the Commandments," he builds on White's teaching that those who pass through the time of trouble must stand "without an intercessor" after Christ leaves the sanctuary in heaven. ${ }^{100}$ Jones proclaimed that believers who die will receive Christ's imputed righteousness, but the last generation will overcome sin completely by the power of an indwelling Christ:

We finally have so much of Christ's divine nature in us that we can draw the bow strongly enough to hit the mark, and then we will be keeping the commandments of God.... Those who live to the end are made sinless before he comes, having so much of Christ's being in them that they 'hit the mark' every time, and stand blameless without an intercessor. ${ }^{101}$

In fact, in Jones's view death is incompatible with obedience, so that "when the day

${ }^{98}$ From an unpublished autobiographical manuscript, quoted by his biographer. Steinweg, Without Fear or Favor, 51-52.

${ }^{99}$ Seventh-day Adventist Encyclopedia, 2d rev. ed. (1996), s.v. "Jones, Alonzo T."

${ }^{100}$ E. G. White, Early Writings, 280-281. See p. 47 above.

${ }^{101}$ [Alonzo Trevier Jones], "Fifth Righteousness Sermon at Ottawa, Kansas," Topeka Daily Capital, May 18, 1889, 5. 
comes that we actually keep the commandments of God, we will never die." ${ }^{\prime 102}$

\section{A Complete Cleansing from Sin}

At the 1893 and 1895 General Conference sessions, Jones presented two series on “The Third Angel's Message.” In the 1893 series he noted the importance of character perfection in the sequence of final events. The latter rain, that would prepare believers for the time of trouble and for translation, was believed to have begun. Jones held this forth as a cause for "good cheer," since "the tests that the Lord [was] giving" were to prepare them for translation. And since sin cannot be translated, "the only purpose that He has in showing us the depth and breadth of sin is that He may save us from it and translate us." ${ }^{\text {"103 }}$ Thus Jones understood the purifying process to take place before translation - an uncovering and elimination of sin buried in the human heart.

A little later in the series, Jones again focuses on the work of cleansing from sin. Reminding his listeners that Ellen White had said they could not receive the seal of God "if there be stains of sin there," Jones asked, "Which would you rather have, the completeness, the perfect fulness of Jesus Christ or have less than that with some of your sins covered up that you never know of? ... He cannot put the seal, the impress of His perfect character, upon us until He sees it there. . . . He will cleanse the heart, and bring up the last vestige of wickedness." "104

${ }^{102}$ Ibid.

${ }^{103}$ Alonzo Trevier Jones, “The Third Angel's Message - No. 10,” Daily Bulletin of the General Conference, February 9-10, 1893, 205.

${ }^{104}$ Alonzo Trevier Jones, “The Third Angel's Message - No. 17," Daily Bulletin of the General Conference, February 26, 1893, 404. 


\section{The Seal of Perfection}

According to Jones it is when the image of God is perfected in His people that the Holy Spirit can place His seal on them. "When the image of God in Jesus Christ is found in us, what then? There is the impress, the seal of God." The effect of beholding Christ is "to perfect the image of God, and restore it in us, by the working of the Spirit of God upon the soul. And when that is done, then the same Spirit of God is there to affix the seal of the living God, the eternal impress of His own image." Once this seal is in place, believers "can stand through the time of the plagues." 105

\section{Replicability of Christ's Victory}

At the 1895 General Conference, Jones turned his attention to the process by which believers come to reflect the image of God, as Christ did in His life. He declared that Christ's "own divine image" is reflected from the hearts of believers. "And this will be so perfectly accomplished that when He comes, in every believer upon whom He looks He will see Himself."106

Near the end of this series Jones took up the question of Satan's accusations and how they were met by Christ in His earthly life. In the context of the cosmic controversy between God and Satan, Jones reviews the charges of Satan regarding God's justice. When God justifies repentant sinners, Jones characterizes Satan's complaints thus:

“These are my property. They are my rightful subjects. They are laden with sin and

${ }^{105}$ Alonzo Trevier Jones, “The Third Angel's Message.-No. 18," Daily Bulletin of the General Conference, February 27, 1893, 415-416.

${ }^{106}$ Alonzo Trevier Jones, “The Third Angel's Message.-No. 20,” General Conference Bulletin, February 27, 1895, 379. 
are altogether wicked. Yet you call them out and justify them and hold them before the universe, and propose to hold them up before the universe as though they had been good all the time. That is not fair. They are sinners; they are wicked. They are just like the rest of us over here." 107

Jones compares the devil to slave holders who would prosecute their runaway slaves under the Fugitive Slave Law, pointing out that the only reason Satan could argue his case was that "the battle had not been fought and the victory won so completely that his argument and his right as a prosecuting attorney should be annihilated." Jones declares that this is what happened when "Christ came in the flesh." "Jesus came here into Satan's territory and took human nature at the point to which Satan himself had brought it. In this human nature He met Satan on his own ground and against all his own power defeated him merely by the power of trusting in right itself as against might." Thus, according to Jones, Satan as prosecuting attorney is "shut out; he has no case at all."108

The concept of God manifesting Himself in sinful flesh is the key for Jones's view that the final generation will duplicate what was demonstrated in Christ's life. According to this understanding, Christ Himself must take the same human nature as all others since the Fall, and conquer Satan in that nature:

In Jesus Christ as He was in sinful flesh, God has demonstrated before the universe that He can so take possession of sinful flesh as to manifest His own presence, His power, and His glory, instead of sin manifesting itself. And all that the Son asks of any man, in order to accomplish this in him, is that the man will let the Lord have him as the Lord Jesus did. ${ }^{109}$

${ }^{107}$ Alonzo Trevier Jones, “The Third Angel's Message.-No. 23,” General Conference Bulletin, March 4, 1895, 447.

${ }^{108}$ Ibid., 448.

${ }^{109}$ Alonzo Trevier Jones, “The Third Angel's Message.-No. 15," General Conference Bulletin, February 22, 1895, 303. 
Jones sees this indwelling of the human by the divine as what the Old Testament sanctuary was meant to teach—that God would manifest Himself in sinful flesh: "In putting His temple among sinful men and dwelling therein Himself, He was showing also how He would Himself dwell in the temple of Christ's body, among sinful men and in sinful flesh." 110 Taking his cue from Paul's words regarding the "mystery of godliness" as "God manifest in the flesh" (1 Tim 3:16), Jones contends that the mystery is "not God manifested in sinless flesh, but in $\sin f u l$ flesh.” And just as, in Jones's view, God was able to indwell sinful flesh in Christ, He is equally able to manifest Himself in those who follow Christ in faith:

God will so dwell in our sinful flesh today that although that flesh be sinful, its sinfulness will not be felt or realized, nor cast any influence upon others; that God will so dwell yet in sinful flesh that in spite of all the sinfulness of sinful flesh, his influence, his glory, his righteousness, his character, shall be manifested wherever that person goes. ${ }^{11}$

All of this Jones sees as encompassed in the work of the third angel's message, which is to prepare believers for translation. In his 1901 book on the prophecies of Revelation, The Great Nations of To-day, Jones connects his teaching regarding the "mystery of God" and the third angel's message: "In this Message was 'the mystery of God' revealed in all its fullness,- God manifest in the flesh,- Christ in men 'the hope of

${ }^{110}$ Alonzo Trevier Jones, “The Third Angel's Message.-No. 25," General Conference Bulletin, March 5, 1895, 477.

${ }^{111}$ Alonzo Trevier Jones, “The Third Angel's Message.-No. 20,” General Conference Bulletin, February 27, 1895, 377. 
glory." This message was given "that men might be fitted to stand holy and without blame before God," ready for translation. ${ }^{112}$

\section{Cleansing of the Sanctuary}

The factor that makes overcoming a necessity for the end-time generation, in Jones's understanding, is the cleansing of the sanctuary in heaven. He sees Daniel's prophecy of the seventy weeks as fundamental for understanding this: "Seventy weeks are determined upon thy people and upon thy holy city, to finish the transgression, and to make an end of sins, and to make reconciliation for iniquity, and to bring in everlasting righteousness, and to seal up the vision and prophecy, and to anoint the most Holy" (Dan 9:24). ${ }^{113}$ In a sermon preached at the 1903 General Conference session Jones closely tied the cleansing of the saints on earth to the cleansing of the sanctuary in heaven:

There is a cleansing of the sanctuary in heaven. That is true. And while that is going on in heaven, and there is the making an end of sins there, and a reconciliation of iniquity there, and finishing of transgression there, and all that, yet if that is not also done in the saints and believers on the earth, then that cleansing of the sanctuary can never end. We never could, in that case, come to the end of this world. ... ... The sanctuary can not be cleansed until transgression is finished in your life and

\footnotetext{
${ }^{112}$ Alonzo Trevier Jones, The Great Nations of to-Day (Battle Creek, MI: Review and Herald, 1901), 152.

${ }^{113}$ It is probably significant that W. W. Prescott, back from England to become vice-president of the General Conference (see Seventh-day Adventist Encyclopedia, 2d rev. ed. [1996], s.v. "Prescott, William Warren"), led a Bible study on this verse with the Indiana ministers at a general meeting of the Indiana Conference just after the 1901 General Conference session (Alonzo Trevier Jones, "General Meeting in Indiana," General Conference Bulletin, Second Quarter, 1901, 512). It was in Indiana that the "holy flesh" teaching had arisen, and this had just been dealt with by the 1901 General Conference. See pp. 166-169 below.
} 
mine; till an end of sins is made in your life and mine. ${ }^{114}$

Thus in Jones's thinking the timing and realization of the Second Advent depends on the removal of sin from the saints on earth.

Jones would make this point even more strongly in his book The Consecrated Way to Christian Perfection, published in 1905. In chapter 15, "The Cleansing of the Sanctuary," he stresses that "the ending of the work of the gospel is, first, the taking away of all vestige of $\sin$ and the bringing in of everlasting righteousness-Christ fully formed — within each believer, God alone manifest in the flesh of each believer in Jesus." 115 Only "when the stream that flowed into the sanctuary" was "stopped at its source" could the sanctuary be cleansed in the typical service "from the sins and transgression which, from the people, by the intercession of the priests, had flowed into the sanctuary." 116 Jones thus saw the removal of sins from the lives of believers as prior to the removal of all sin from the sanctuary.

In this way the blotting out of sins, that according to Jones comes before the latter rain, is seen more as the acquisition of complete victory over $\sin$ in the life, and not as much the removal from the heavenly records of sins for which prior confession has been made. Jones exhorts his readers to "repent and be converted that our sins may be blotted out, that an utter end shall be made of them forever in our lives ... that the fulness of the outpouring of the Holy Spirit shall be ours in this time of the refreshing of the latter

${ }^{114}$ Alonzo Trevier Jones, "What It Means to Be a Church-Member," General Conference Bulletin, April 1, 1903, 43.

${ }^{115}$ Jones, The Consecrated Way to Christian Perfection, 117.

${ }^{116}$ Ibid., 118-119. 
rain." 117 There is no question that Jones expected end-time believers to attain to a "state of perfection in the complete image of Jesus," 118 and that the second coming of Christ was dependent on the actualization of such overcoming by the end-time saints. What is not as clear is whether he believed this final-generation perfection contributed to the vindication of God in the conflict with evil. It is certainly implied by his making the cleansing of the sanctuary dependent on the attainment of perfection on the part of the last generation. But it is not explicit. For that one must turn to his fellow advocate of righteousness by faith, E. J. Waggoner.

\section{E. J. Waggoner Advances Eschatological Vindication}

Ellet J. Waggoner was the son of Adventist pioneer, J. H. Waggoner, who had addressed at some length the specific issues involved in the atonement as it related to the vindication of God in the controversy between God and Satan. ${ }^{119}$ E. J. Waggoner left a career in medicine for evangelistic and editorial work, and with A. T. Jones was a proponent of righteousness by faith at and after the 1888 General Conference session. ${ }^{120}$ Waggoner, like his father, turned his attention to the question of the vindication of God in

${ }^{117}$ Ibid., 125.

${ }^{118}$ Ibid., 124.

${ }^{119}$ See pp. 109-113 above.

${ }^{120}$ Seventh-day Adventist Encyclopedia, 2d rev. ed. (1996), s.v. "Waggoner, Ellet J.' 
the cosmic conflict between good and evil, focusing more than his father on the nature of an end-time vindication of God.

\section{Independent of Humans}

Though Waggoner made the case in no uncertain terms that God is dependent on human witnesses for vindication of His honor in the final judgment, before he finalized such ideas he expressed what seem to be contrary views. In one of Waggoner's earliest mentions of vindication, in his Christ and His Righteousness of 1889, he pointed out that God "vindicates the integrity of His law by submitting in His own Person to the penalty which was due the sinner." ${ }^{\prime 21}$ Thus Waggoner recognized the cross as the vindication of God's law early after 1888 . And in 1894 he repeatedly made the case that God is not dependent on humans for the outcome of the conflict. As editor of The Present Truth in London, he contended that "men have nothing to do with giving Christ His kingdom." Even if "all the men on earth should refuse" the gospel invitation, "God would raise the children to Abraham from the stones of the ground." 122

\section{Dependent on Humans}

However, Waggoner's later teaching, that God has need of human witness to clear

${ }^{121}$ Ellet Joseph Waggoner, Christ and His Righteousness (Oakland, CA: Pacific Press, 1889), 63.

${ }^{122}$ Ellet Joseph Waggoner, "The Authority of Christ," Present Truth, April 12, 1894, 231; idem, "Front Page," Present Truth, August 30, 1894, 545. See also the same thought expressed while speaking of God on trial before the universe, in idem, "Letter to the Romans - No. 3," Daily Bulletin of the General Conference, March 10, 1891, 63. For further evidence and analysis of this earlier view of Waggoner's, see Woodrow W. Whidden, E. J. Waggoner: From the Physician of Good News to the Agent of Division (Hagerstown, MD: Review and Herald, 2008), 298-304. 
His name successfully in the great conflict with evil, is clear. At the 1899 General Conference session he proclaimed that the translation of end-time believers into the heavenly realm without seeing death "is not simply that the Lord comes and translates us because he does not give us time to die. God is working out a marvelous plan for his own glory." ${ }^{23}$ Just as Jones did, Waggoner saw great meaning in the end-time perfection of believers. For instance, in The Everlasting Covenant, published in 1900, Waggoner declared that the "complete cleansing of the people of God on this earth" was connected not only with their translation without seeing death, but also with the cleansing of the sanctuary in heaven. ${ }^{124}$ However, in regard to issues involving eschatological judgment and vindication, Waggoner was more explicit than Jones.

\section{Purpose of the Judgment}

As early as 1890 Waggoner was portraying the final judgment as a trial of God's character. In a Signs of the Times article, he declared that "God condescends in all His ways to submit them to the judgment of the people." ${ }^{25}$ A few months later, at the 1891 General Conference session, he clearly linked the judgment with the charges of Satan against God: "God is himself on trial before the universes, and Satan and evil men have always charged him with being unjust and arbitrary; but in the judgment all the universe

123 “Twelfth Meeting, Tuesday, 2:30 P. M., February 21," Daily Bulletin of the General Conference, February 23, 1899, 58.

${ }^{124}$ E. J. Waggoner, The Everlasting Covenant, 366.

${ }^{125}$ Ellet Joseph Waggoner, "Romans 3:9-12 (Concluded)," Signs of the Times, August 25, 1890, 458. 
will say, 'Just and true are thy ways, thou King of saints.",126 The purpose, then, of the judgment is not for "God to judge of the character of men, but to cause men to see the true character of God," Waggoner made plain in an 1899 Present Truth article. ${ }^{127}$

\section{Use of Witnesses}

Toward the end of the 1890s Waggoner made a strong case for the role of humans as witnesses for God in the end-time judgment. Already in 1893 he began to give an important role to the transformed lives of Christ's followers in the judgment. ${ }^{128}$ But on Sabbath morning, March 6, near the end of the 1897 General Conference session, Waggoner delivered a sermon entitled "Witnesses for God," that fully set forth the case for human witnesses in the judgment. "We are now on trial, and soon the judgment will be pronounced, to decide our eternal destiny. But there is a good deal more pending in that heavenly court than that. God has a case there. He himself is on trial, and this fact with which we have to do is of far greater importance to us than the interests which pertain to ourselves alone." Waggoner pictured God as being quiet and patient with all the charges and accusation of Satan and his sympathizers throughout history as to why He permits sin and suffering, "but he relies upon the future trial to demonstrate to the assembled universe the righteousness of his cause." Waggoner portrays God in the time

${ }^{126}$ E. J. Waggoner, "Letter to the Romans - No. 3," 63. See also idem, "Studies in Romans: The Sum of the Matter," Signs of the Times, January 9, 1896, 19.

${ }^{127}$ Ellet Joseph Waggoner, "The Gospel of Isaiah: The Great Case at Law," Present Truth, January 5, 1899, 4.

${ }^{128}$ Ellet Joseph Waggoner, "Witnesses for God," Present Truth, December 14, 1893, 577-578. 
of judgment challenging His opponents, "Let all the nations be gathered together. Let them bring forth their witnesses, that they may be justified, or let them hear, and say, It is truth." Waggoner goes on to clearly make God's vindication in the end-time dependent on humanity. "God has left the vindication of his character to his children. He has, as it were, risked his character with men." ${ }^{\prime 29}$ Waggoner reasons that God is very patient with His people, since the results He is looking for are so critical. God "does not become impatient" with believers, for "he has his character at stake. The only way in which he can demonstrate the perfection of his character, and take away his reproach, is in perfecting a people to his praise." ${ }^{n 0}$

Waggoner advanced the concept further in the following years. In an 1898 Present Truth article he describes the 144,000 as those whom God desires to "be known everywhere as the proofs of His saving power. He is willing to be judged by these results and He puts His own seal upon them." ${ }^{\text {131 }}$ The following year he made the point even

${ }^{129}$ Ellet Joseph Waggoner, "Witnesses for God," General Conference Bulletin, First Quarter, 1897, 54-55. This is an "abstract" of Waggoner's sermon.

${ }^{130} \mathrm{Ibid} ., 57$. It is interesting to note the reception that this message had among the delegates. According to a report on the "Sabbath Services" in the last number of the Daily Bulletin for this conference, many were moved to tears. "The fact that God has, as it were, risked his reputation or character in our hands, and that we are in our lives to bear witness to his goodness and justice, was dwelt upon at some length. No outline of the discourse can give any idea of the spirit that came upon the meeting as the speaker proceeded. No appeal was made to the feelings of the audience, but at the close of the sermon many were in tears, and after the dismissal the people lingered weeping in silent and inexpressible gratitude and awe at the wonderful grace of God. It was not an occasion for words, for no words could give expression to the deep feelings of the heart. Never have we seen such a manifestation of the subduing power of the Holy Spirit." "Sabbath Services," General Conference Daily Bulletin, March 8, 1897, 319-320.

${ }^{131}$ Ellet Joseph Waggoner, "Notes on the International Sunday School Lesson: The Captivity of Judah: Jeremiah 52:1-11," Present Truth, December 8, 1898, 770. 
more strongly, claiming that God "has such confidence in man, ... that He is willing to risk His character with him, and to this end He calls upon men to be His witnesses."

\section{Witnesses Replicate Christ's Life}

Key to Waggoner's concept, as he brought it out in an 1898 Present Truth article entitled "The Sanctuary of God," is the idea that God must show that Jesus was not "a unique specimen" beyond the possibility of replication. Rather, to counter Satan's charges that God "is not able to make a man born in sin, and bring him to perfection," "the life of Jesus is to be perfectly reproduced in His followers." Waggoner understood that "the new birth puts men in the same position that Christ occupied on this earth." "Before the end comes, ... there must be a people on earth ... in whom 'all the fulness of God' will be manifest even as it was in Jesus of Nazareth. God will demonstrate to the world that what he did with Jesus of Nazareth He can do with anyone who will yield to Him."133

At the 1901 General Conference session, Waggoner preached an evening sermon in which he made the further point that this witness of what God can do in humans must be manifested "before probation ends," when people still are able to decide for God. Otherwise, "it would not be a testimony" to the people. This testimony consists of Christ living "a sinless life in sinful flesh, and a healthful life in mortal flesh, and that will be a

${ }^{132}$ Ellet Joseph Waggoner, “God's Witnesses,” Present Truth, June 1, 1899, 339.

${ }^{133}$ Ellet Joseph Waggoner, “The Sanctuary of God," Present Truth, December 8, 1898, 774. This also appears in idem, The Everlasting Covenant, 366-367. 
testimony that can not be gainsaid,- - witness than which no greater can be given. Then the end will come." $" 134$

\section{God Manifest in Sinful Flesh}

Thus God is seen as manifesting His righteousness in the sinful flesh of believers. In his Sabbath morning sermon at the 1897 General Conference, Waggoner shared his expectation that God could "take sin out of us and put Christ into us," which he described as "nothing short of a miracle," "nothing less than the mighty power of God."135 At the 1899 General Conference, he challenged delegates to think of what the result would be of "the life of Christ being manifest in mortal flesh." Waggoner maintained that "if the life of Jesus is manifest in our mortal flesh, we shall be in this world the same as he was. Disease will be around us, but it will not hold us." Though Waggoner warned against condemning those who were sick, he exhorted believers, "still the Lord wants us to learn the possibilities of the gospel to fit us for translation." ${ }^{\prime 36}$ It is evident, therefore, that Waggoner expected that the manifestation of Christ's life in sinful flesh would have a powerful effect over the physical body. When asked by one person if he expected ever to get sick, he replied, "I expect to live forever," and also wondered why Adventists should ever need to be absent from work due to illness. ${ }^{137}$

\footnotetext{
${ }^{134}$ Ellet Joseph Waggoner, "Sermon, April 6, 7 P.M.," General Conference Bulletin, April 9, 1901, 147.

${ }^{135}$ E. J. Waggoner, "Witnesses for God (General Conference Bulletin)," 56.

136 "Eleventh Meeting, Tuesday, 9:30 A. M., February 21," Daily Bulletin of the General Conference, February 22, 1899, 53.

${ }^{137}$ Ibid.
} 
After the "holy flesh" teaching arose briefly around the year 1900, Waggoner made clear his opposition to the belief that one's flesh may become sinless. At the 1901 General Conference session he pointed out the mistake of those who "get the idea that their flesh is sinless," declaring that they were "confounding their sinful flesh with the Spirit of God," believing that "all their impulses are from God."138 Nonetheless he did believe that the Adventist doctrine of the blotting out of sin in connection with the cleansing of the heavenly sanctuary was much more than deleting entries from the record books in heaven. In an article in 1902 on the blotting out of sin, Waggoner cautioned that one should "be on our guard against the idea that the blotting out of sin is merely as the passing of a sponge over a slate, or an entry in a ledger, to balance the account. This is not the blotting out of sin." Rather, "the blotting out of sin is the erasing of it from the nature, the being of man." Just as waves gradually erase what is written in the sand on the shore, so "the stream of life from the throne of God will wash away and blot out the impressions of sin upon us." Waggoner bases this on Heb 10:2: "The worshipers once purged should have had no more conscience of sins." He interprets this to mean that, for such ones, sin is "foreign to their new natures, and even though they may be able to recall the fact that they have committed certain sins, they have forgotten the sin itself- - they do not think of doing it any more. This is the work of Christ in the true sanctuary."139

Regardless of the difficulty of completely understanding what Waggoner meant by

${ }^{138}$ E. J. Waggoner, "Sermon, April 6," 146. See pp. 166-169 below, on the "holy flesh" movement.

${ }^{139}$ Ellet Joseph Waggoner, "The Blotting out of Sin," Advent Review and Sabbath Herald, September 30, 1902, 8. 
the retention of sinful flesh, while sins have been blotted from one's nature or being, it is clear that he understood this effective transformation as "God's great sign to the universe, ... the perfect sign of his coming — that is, his manifestation here in the flesh." ${ }^{\prime 140}$ It was an indispensable element of God's strategy for answering the challenges laid out by Satan in the controversy between good and evil.

\section{The "Holy Flesh" Movement and Final-Generation Theology}

As noted previously, the "holy flesh" movement sprang up in Indiana around 1900. The Indiana Conference president, R. S. Donnell, and other ministers promoted a "cleansing message" whose purpose was to prepare believers for translation. This teaching is relevant to a study of the background of final-generation theology, as the proponents' overriding concern was to accomplish a needed cleansing work in preparation for translation. They saw this cleansing as the eradication of sin from believers' lives, a goal which tracks very closely to that promoted by leaders such as A. T. Jones, E. J. Waggoner, and even Ellen White. However, all three of the post-1888 proponents of righteousness by faith quickly took issue with this new teaching. ${ }^{141}$

${ }^{140}$ Ellet Joseph Waggoner, "Sermon, April 16, 7 P.M.," General Conference Bulletin, April 22, 1901, 406. It is easy to see that for Waggoner the Sabbath has a natural eschatological significance. As the sign of God's perfect creation, it will also "mark God's finished, new creation; therefore the Sabbath is the seal of perfection. The keeping of the Sabbath, then, is simply the partaking of God's perfection." Idem, "Studies in the Book of Hebrews - No. 1 (Tuesday Afternoon, Feb. 9, 1897)," General Conference Daily Bulletin, February 12, 1897, 6.

${ }^{141}$ For a brief overview of the movement, see Richard W. Schwarz, Light Bearers to the Remnant: Denominational History Textbook for Seventh-Day Adventist College Classes (Mountain View, CA: Pacific Press, 1979), 446-448. 


\section{Cleansing in Preparation for Translation}

The "cleansing" preparatory to translation was very much related to the Adventist understanding of the cleansing of the sanctuary. Donnell taught that God's purpose in creating other beings was that He might dwell in them and be manifested in them. But when humanity sinned, God could no longer dwell in them, because Satan became incarnate in them, "and God and Satan cannot dwell together. The only reason why God does not dwell in man is because sin is there, and in order for God to again dwell in man sin must be eradicated. ... The cause for God's forsaking humanity as His temple must be removed before He can return and again occupy it as was His purpose from eternity." ${ }^{142}$ Thus far there is little to distinguish this from the view of A. T. Jones, who also viewed the sanctuary cleansing as being first a cleansing of the hearts of believers from "the last vestige of wickedness," or from that of E. J. Waggoner, who saw the last generation as those from whom sin is removed and Christ fully indwells. ${ }^{143}$ But both Jones and Waggoner stressed that final-generation believers would replicate Christ by living sinless lives in sinful flesh. ${ }^{144}$

\section{God Manifest in Sinless Flesh}

Donnell, on the other hand, could not conceive of divinity coexisting with sin, so that it was necessary for end-time believers to be rid of their sinful natures in order that

${ }^{142}$ R. S. Donnell, "What I Taught in Indiana," [1907?], Ellen G. White Estate Branch Office Document File 190, CAR, 5-6.

${ }^{143}$ Jones, "The Third Angel's Message - No. 17," 404; E. J. Waggoner, "Witnesses for God (General Conference Bulletin)," 56. See pp. 152, 164 above.

${ }^{144}$ See pp. 154-155, 164-166 above. 
Christ might dwell in them fully. Just as Christ could not become human unless His flesh was untainted by sin, so believers must accept this same sinless living in sinless flesh, Donnell taught. "This removal [of the cause of God's forsaking His human temple] was [sic] wrought when Christ becomes incarnate in human flesh, even in yours and mine: for conversion is only incarnation going right on, God being manifest in the flesh." ${ }^{145}$ Thus a different understanding of the incarnation of Christ led Donnell to somewhat different conclusions as to the nature of the preparation necessary for translation.

Just as Waggoner and Jones, Donnell felt a need to distinguish as to what was changed about a person's nature when he/she was indwelt fully by God. In an essay entitled "The Nature of Christ and Man," Donnell defined the needed cleansing of the soul temple as "taking the mind or nature which Adam received in the fall, which is the mind of Satan, out of humanity, and the restoring back to man that nature which Adam had before he fell. ${ }^{146}$ Following Ellen White, this would include being rid of sinful propensities and character defects, but "man's fallen Physical [sic] nature is not redeemed in this life. Provision has been made for its health, and cleansing from sin, but deterioration in size, and in strength, is not to be restored until in the earth made new." 147 Thus, Donnell includes a cleansing from sickness, but not from the inherited physical

${ }^{145}$ Donnell, "What I Taught in Indiana," 6.

${ }^{146}$ R. S. Donnell, "The Nature of Christ and Man," an essay written in Memphis, TN, about the year 1900 and sent to S. S. Davis. Copy in the files of William H. Grotheer. Quoted in William H. Grotheer, The Holy Flesh Movement: 1899-1901 (Florence, MS: Adventist Laymen's Foundation of Miss., 1973), 28.

${ }^{147}$ Ibid., 1, quoted in Grotheer, 27. Cf. Ellen G. White, "Christian Perfection," Advent Review and Sabbath Herald, April 24, 1900, 257. 
effects of one's ancestors. Here Donnell seems to make a fine distinction, the body being cleansed only "as far as its life or actions are concerned."148 At the least, it is evident that a number of Adventists at the beginning of the twentieth century felt the need of a preparation for translation that included the manifestation of God in their lives to a similar extent as He was manifest in Christ's life on earth, whether in sinful or sinless flesh.

\section{Last-Day Events in the Writings of Other Adventist Authors}

Many examples of a spirit of urgency to prepare for translation can be found in other Adventist writers during the post-1888 period. Especially at the end of the nineteenth century and during the first few years of the twentieth, a wave of enthusiasm seems to have washed over the Adventist believers. At the 1897 General Conference session, European Council chairman H. P. Holser preached a sermon Sabbath morning based on Rev 18:1-4 in which he reminded delegates that they were living in the time of the latter rain: "We are in the shadow of the time of trouble, but we must confess that the power that is to attend the latter rain is what we do not possess." ${ }^{149}$ Similarly, General Conference president George A. Irwin, in the lead off Week of Prayer reading for 1899, called for "a return to the old-time spirit of self-sacrifice and self-denial," which must be seen "before there can come the great outpouring of the Spirit of God that is to enlighten

${ }^{148}$ Donnell, "What I Taught in Indiana," 24.

${ }^{149}$ H. P. Holser, "God's Glory,” General Conference Daily Bulletin, February 17, 1897, 54. For Holser's position in Europe, see Seventh-day Adventist Encyclopedia, 2d rev. ed. (1996), s.v. "Holser, Henry P." 
the whole world with its glory, and prepare a people for translation." ${ }^{150}$ This was followed by a reading entitled "Prepare for Translation" by John A. Brunson, a minister working in the newly opening Southern field. ${ }^{151}$ Irwin preached a sermon at Battle Creek the following February, in which he called for "the definite, clear-cut, and distinct message that God would have given in these times, to separate a people from the world, and fit them for translation to heaven."

\section{Standing without a Mediator}

Besides the necessity of preparing for the latter rain and translation without seeing death, also evident in sermons and articles during this period was the specific understanding among at least some Adventists that, in view of the coming time of trouble, they needed to be rid of sin to the extent that they would not require the services of a Mediator in the heavenly sanctuary. In 1891 G. W. Draper, in his concluding article on "Holiness," reminded readers of the Review that "those who are translated without seeing death, will have to stand without a Mediator, and consequently without sin." ${ }^{153}$ At the 1893 General Conference session, New England Conference president R. C. Porter 1899, 77.

${ }^{150}$ George A. Irwin, “The Last Call,” General Conference Bulletin, Fourth Quarter,

${ }^{151}$ John A. Brunson, "Prepare for Translation," General Conference Bulletin, Fourth Quarter 10, 1899. For Brunson's location in the South, see "Special Winter Term of the Southern Industrial School," Advent Review and Sabbath Herald, December 26, 1899.

${ }^{152}$ George A. Irwin, “The Third Angel's Message," General Conference Bulletin, First Quarter, 1900, 107.

${ }^{153}$ G. W. Draper, "Holiness (Concluded)," Advent Review and Sabbath Herald, August 4, 1891, 482 (2). 
admonished delegates, "We must expect to get rid of sin that we may stand without a mediator while the seven last plagues are falling." 154

At the 1899 General Conference session in South Lancaster, Massachusetts, John Brunson, a minister who was to be of assistance to the work in the South, was the speaker for the main worship service at the opening Sabbath of the conference. His message, "Preparation for Translation," stirred the delegates so much that the General Conference Daily Bulletin reported:

Elder J. A. Brunson gave the trumpet a certain sound in an appeal to prepare for translation at the soon coming of the Lord. It was indeed a revival of the message of days of old, and caused a thrill of solemn joy in the hearts of those who have long loved the message of the Master's near return. It was the third angel's message in purity and power. ${ }^{155}$

Addressing the qualifications for translation, Brunson proclaimed that "more is required of the candidates for translation than from any other people. We are to live, you know, without a mediator." After confirming the existence of the "space of time" that comes between the close of probation and the second coming of Christ during which no Mediator intercedes in the sanctuary, Brunson asks, "Did you ever stop to think why we are to live without a mediator?-Because there is no necessity for one.” He goes on to explain that since sin entered, Christ has been mediating between guilty humans and a

${ }^{154}$ R. C. Porter, "The Mind of Christ - No. 5," Daily Bulletin of the General Conference, February 5, 1893, 144. For biographical data, see Seventh-day Adventist Encyclopedia, 2d rev. ed. (1996), s.v. "Porter, Roscoe Celester."

155 “A Notable Day,” Daily Bulletin of the General Conference, February 19, 1899, 25. For his coming to the Southern Industrial School, see "Special Winter Term of the Southern Industrial School." 
holy God, but that this work will cease when "every child of God is sealed for heaven."156 When believers "have been cleansed from all defilement of the flesh and spirit, and stand before God holy and righteous," they no longer need " the work of a mediator." Brunson pointed out the difference between believers who had died and those who would be translated. The first group died in Christ in their "fleshly imperfection," but with available mediation. Brunson clearly declared to the delegates, "You and I are to get beyond that point.... We must get to a point of perfection such as the world has never yet seen." ${ }^{157}$ Neither would Brunson allow excuses for the weakness of the flesh:

Everything that tends to alienate the character from the living God must be taken out of our hearts before God can translate us. "Oh, but," you say, "you must consider the weakness of the flesh." It is not for me to consider the weakness of the flesh. God considered that before he ever made the plan of salvation. When God made the plan of salvation, he made a plan that was fitted for sinful, weakened human beings; and I praise God that he did. And if God in his infinite wisdom and power, planning as he did, has given to us the standard of perfection, it is not for you and me to stand and excuse ourselves because we are still in the flesh. ${ }^{158}$

Brunson repeated the main points of his sermon in the Week of Prayer reading he was assigned to write for the end of the year. He further stated here that the "necessity for mediation" "will cease only when God's children in the flesh have been restored to that complete harmony with God which was enjoyed by man before he sinned." Candidates

${ }^{156}$ John A. Brunson, "Preparation for Translation," Sermon Feb. 18, Daily Bulletin of the General Conference, February 20, 1899, 39.

${ }^{157}$ Ibid.

${ }^{158}$ Ibid., 40. 
for translation "will reach that state of perfection, while in the flesh, in which the image of Christ is perfectly reflected." 159

That such sentiments were not wholly isolated can be inferred from the glowing report of the message in the General Conference Bulletin and the fact that later in the year the General Conference Committee assigned Brunson to write one of the Week of Prayer readings for that year. ${ }^{160}$ And in another reading for the Week of Prayer that year, General Conference secretary L. A. Hoopes challenged readers with the necessity of getting "the victory over every besetting sin, over every wrong word and action. ... It is not enough that we get an occasional victory over our besetments. We must maintain that victory all the time." ${ }^{.161}$ Neither did such expectations end in the 1899-1901 era. In 1905 A. T. Robinson, returned missionary from South Africa and Australia, expressed the opinion that the power of God would "keep the one hundred and forty four thousand from sin, for at least one whole year after the close of probation." ${ }^{162}$ Pioneer Stephen Haskell, at the 1909 General Conference session, spoke of the Spirit of Prophecy as a gift that had been given to Adventists to "bring into their experience every gift that God has placed in

${ }^{159}$ Brunson, "Prepare for Translation," 79.

${ }^{160}$ General Conference of Seventh-day Adventists (Battle Creek, MI), Minutes of Meetings of the General Conference Committee, October 3-31, 1899, meeting of 10:30 a.m., October 9, 1899.

${ }^{161}$ L. A. Hoopes, “Take Heed Lest Ye Fall," General Conference Bulletin, Fourth Quarter, 1899, 92. For biographical data, see Seventh-day Adventist Encyclopedia, 2d rev. ed. (1996), s.v. "Hoopes, L. A."

${ }^{162}$ A. T. Robinson, "Our Message," Advent Review and Sabbath Herald, July 20, 1905, 9. For biographical data, see Seventh-day Adventist Encyclopedia, 2d rev. ed. (1996), s.v. "Robinson, Asa T." 
his church to perfect a people that they may be blameless. May the Lord help us to be among the number that will be translated when he comes."163

\section{End-time Vindication of God}

Though the concept of complete overcoming of sin on the part of the final generation is frequently and emphatically expressed during the post-1888 years, the idea that this perfect reflection of Christ will serve to vindicate God in the battle with evil is not as prevalent. However, this understanding is certainly not without its witnesses.

Besides E. J. Waggoner's testimony cited above, ${ }^{164}$ that of I. H. Evans and Uriah Smith may be helpful in connection with this review of post-1888 "final generation" ideas.

I. H. Evans was serving as president of the Mission Board during 1899, and became manager of the Review and Herald office in $1901 .^{165}$ Evans wrote one of the Week of Prayer readings for 1900, entitled, "'Ye Are My Witnesses."” In this message he used the experience of the prophet Elijah at Mount Carmel as a model of the role of lastday saints in vindicating God. He argued that "the third angel's message can never be taught to men and women in theory alone," but that truth should be "demonstrated" in the lives of believers. "We claim to be preparing for translation. We teach the world that this is the last generation of men, and this message is especially given of God to fit a people for translation." Then it should produce "the fruits which we say it is ordained to

\footnotetext{
${ }^{163}$ Stephen Nelson Haskell, “The Spirit of Prophecy," General Conference Daily Bulletin, May 31, 1909, 229.

${ }^{164}$ See pp. 161-166 above.

${ }^{165}$ Seventh-day Adventist Encyclopedia, 2d rev. ed. (1996), s.v. "Evans, Irwin Henry."
} 
produce," Evans insists. He then juxtaposes the outcome of God's cause and the production of this witness: "May not the world demand that [this message] show forth a spirit, a perfection of all the Christian graces in its followers, such as no other church can demonstrate? This day, the cause of God is at stake." Again, he emphasizes that it is not theories that are placed "one against the other," but the 'fruits of the Spirit' in the life of the receiver. It is the trial of Elijah and Baal's prophets." Evans portrays God as saying to Adventists, "Israel of God, my people whom I am to seal, come, make manifest the patience of the saints before a perishing world. Show what my truth can do for those who receive it." ${ }^{166}$ And this demonstration is not merely to show the effectiveness of the plan of salvation, but also to vindicate God in the eyes of the world, just as Elijah did before the onlookers at Carmel. Evans clearly sees Elijah as a type of the final generation in both his preparation for translation, and also in his opportunity to vindicate God before onlookers: "Yonder is Elijah. He, too, is ripening for translation. ... Before all Israel, is Elijah's God on trial. And how gloriously does Elijah's God triumph! ... Lost to all stains of earthliness, he became fitted to live in glory with the heavenly intelligences.... And, would not God have his servants in these last days, by purity of life, by freedom from contamination with the evils of this world, so walk with him that the power of the Holy One may be seen upon them?"'167 Though the idea of the vindication of God by the righteous living of the final generation is not as clearly expressed by Evans as it was by E.

${ }^{166}$ Evans clearly sees Elijah as a type of the final generation in both his preparation for translation, and also in his opportunity to vindicate God before the onlooking universe. I. H. Evans, “'Ye Are My Witnesses'," General Conference Bulletin, Third Quarter, 1900, 167.

${ }^{167}$ Ibid., 168. 
J. Waggoner, it seems that Evans is following in Waggoner's lead.

Another witness from this period for the existence of the concept of an end-time vindication of God related to the obedience of the end-time saints is Uriah Smith. Smith had been editor of the Advent Review and Sabbath Herald, with only brief interruptions, since 1855. A. T. Jones became editor in 1897, while Smith was an associate editor from 1897 to 1901. Although Smith battled determinedly with Jones and Waggoner over their views on righteousness by faith, it is interesting to observe that he expressed similar ideas regarding the role of the last-day saints in vindicating God's name. Smith clearly recognized the primary role of Christ in vindicating the government of God in the face of Satan's charges. In his 1898 Looking unto Jesus, he wrote: “The course of Christ from the time he consented to step out from his position of equality with God, his life on earth of sorrow and suffering, and his vicarious death, blasted and shattered all the misrepresentations and false charges Satan had uttered against the government of God, to the everlasting discomfiture of the rebel leader and all his hosts." ${ }^{168}$

But Smith also clearly saw that the battle was not yet over, and that God was still in need of vindication at the end of time. In his 1895 tract America's Crisis, Smith drew the attention of readers to the significance of the events then unfolding. "Here and now, in the movements with which it is the lot of the men of this generation to be connected, is to be decided the great controversy which commenced with the defection of the arch-rebel before time began. Shall God or Satan, good or evil, be vindicated, and triumph at

${ }^{168}$ Uriah Smith, Looking Unto Jesus: Or, Christ in Type and Antitype (Chicago, IL: Review and Herald, 1898; reprint, Payson, AZ: Leaves of Autumn Books, 1979), 33. 
last?" ${ }^{169}$ And in Looking unto Jesus he pointed out the responsibility of every person then living: "Every member of the human family is concerned; and all must take their position on one side or the other.... The Devil seeks to win men over to the support of his contention, that the government of God and Christ is partial and unjust, tyrannical in laying upon men laws which they cannot keep, and unmerciful in executing them.."170 Earlier in the same book, Smith addresses at length the charge of Satan that the law was impossible to keep, and God's answer in sending Christ in human flesh to show that there was no problem with the law:

God's throne is charged with guilt. It is claimed that no man could keep the law God had laid upon him, by any possible power in himself or at his command; that it was not just that man should be required to keep such a law, and he never should have been condemned for breaking it. ... But God sent his own Son into the world to show that the whole trouble lay in the base surrender of the flesh to sin, and not to any injustice in the law. He came in the likeness of sinful flesh to demonstrate before all parties in the controversy that is was possible for men in the flesh to keep the law. He demonstrated this by keeping it himself. On our plane of existence, and in our nature, he rendered such obedience to every principle and precept, that the eye of Omniscience itself could detect no flaw therein. His whole life was but a transcript of that law, in its spiritual nature, and in its holy, just, and good demands. He thus condemned sin in the flesh, by living himself in the flesh and doing no sin; showing that it was possible for man thus to live. It was a complete and triumphant vindication of the fact that God is not unjust in his demands; that he required of man nothing more than he could do, nothing more than he should have done, and for the not doing of which he was justly condemned. If Christ here, as a man, could keep the law, fulfilling perfectly the Father's will, man could have done so too, and therefore stands speechless before a throne which is shown to be a throne of equity, before a law which is shown to be holy, just and good, and before the blameless life of Christ, which is shown to be possible in a world like this, and in a condition vastly worse than that in which Adam was placed, when he basely yielded to temptation. ${ }^{171}$

${ }^{169}$ Uriah Smith, America's Crisis (Oakland, CA: Pacific Press, 1895), 30-31.

${ }^{170}$ U. Smith, Looking Unto Jesus, 36.

${ }^{171}$ Ibid., 29-30. 
In the same passage, though, Smith makes the case that the sinless lives of believers also serve to vindicate God's government in regard to the charge of requiring the impossible. Speaking of Christ, Smith declares, "this sinless life, lived in our behalf, may, by faith in him, be appropriated as his own, by any of the class he came to redeem, who are all his creatures. This life manifested here in our nature vindicates the government of God, and clears his throne from all charges of inconsistency in demanding of men, or as if he demanded of men, more than they could do, and condemning them for not meeting requirements which it was impossible for them to perform."”72 Though Smith does not single out the final generation for this task, it is a clear statement of the concept that human obedience can aid in vindicating the justice of God's requirements.

\section{Summary and Conclusion}

During the years 1888-1915, Seventh-day Adventist leaders continued to express a great deal of hope and certainty in regard to what they believed were the soon-coming, closing events of history. Ellen White did not alter the basic outline of end-time events that had become definite very early in her writing career. She continued to exhort believers to prepare for the latter rain and the sealing, by perfecting their characters, though her writing is often marked with indications of an enhanced appreciation of the gift of Christ's imputed righteousness in the years after the 1888 General Conference session. While she had no sympathy for those who claimed to be sinless, she expressed without hesitation that believers preparing for translation must have put on the spotless robe of Christ's righteousness.

${ }^{172}$ Ibid., 29. 
Though White showed a clear understanding of the difference between the imputed and the imparted righteousness of Christ, these often blend in her writing. When she discusses the vision of Joshua and the Angel, it seems that she views the final generation as much less than perfect in behavior, and that the spotless robe given signifies an imputed righteousness. But evidence points to this transaction occurring while Christ's intercessory work is ongoing in the sanctuary in heaven, and not after the close of probation. Whatever she thought about the struggles of those passing through the time of trouble, it is clear that White rejected the arguments of those who denied the possibility of complete overcoming, while maintaining that defects in one's character would bar one from entrance to heaven.

It is perhaps significant that although White clearly teaches an end-time maturation of Christ's followers, who perfectly reproduce His character before He comes, and although she clearly states that Christ's honor is involved in the perfection of endtime believers, she does not use the word vindication in these contexts. When she speaks of God's vindication in the final days, she does not point to the obedience of the end-time saints. Further, during the time of trouble, when the righteous are portrayed as severely tried, she speaks largely in terms of their confidence and faith in God being put to the test, rather than their obedience. In White's depiction of the post-probationary time of testing, the life histories of the 144,000 certainly do not call forth feelings of accomplishment on their part.

The writings of A. T. Jones and E. J. Waggoner provide more explicit testimony to the concept of a final generation that serves to vindicate God's handling of the sin problem by replicating Christ's perfect overcoming. Beginning soon after the 1888 
conference at Minneapolis, Jones preached a complete victory over sin by the end-time saints, through a process of purification, as sin was eliminated and the sinful human nature was overcome by the indwelling Holy Spirit. Key to Jones's view is the prophecy of Dan 9, in which he sees the bringing in of righteousness and the making an end of sins as constituting the last-day cleansing of the sanctuary in heaven. Jones argued forcefully the logic that the sanctuary could not be cleansed while a stream of filth was pouring in, and that the cleansing of the worshipers necessarily precedes the cleansing of the sanctuary.

Waggoner was the first to clearly develop the concept of a last generation of believers on whose perfect overcoming of sin God has staked His honor. Like his father he focused on the charges brought against God in the cosmic controversy between Christ and Satan. But he went further than his father in that he made the role of the final generation of saints critical to the outcome of the controversy between good and evil. In Waggoner's view God depends on humans to be His witnesses in the final judgment, as He puts His justice and goodness on trial before the universe. He argued that it must be shown that Christ was not a unique specimen, but that God can bring to perfection humans, even though born in sin. Both Waggoner and Jones believed that Christ came in human nature that was sinful, and manifested God's righteousness in that flesh, and that any other person can also be a temple in which God can so dwell.

In this, Waggoner differed from the proponents of the "holy flesh" movement of 1899-1901, in which it was taught that Christ came in sinless flesh, and that those who are prepared for translation will have acquired this same flesh in order that they might be fully indwelt by God. But both groups stressed complete victory over sin in anticipation 
of translation without seeing death, and also believed the indwelling of the Holy Spirit would affect a person's physical nature. This led to the belief that one could be beyond the reach of sickness (and death, in the eyes of Jones and Waggoner, at least).

Other Adventist writers spoke of the urgency of overcoming all sin in preparation for translation. The concept of standing during the time of trouble in the presence of a holy God without a Mediator led to the understanding that God's people could not be sinning during the time of trouble. Especially during the late 1890s and as the twentieth century dawned, this is evident. John Brunson, a worker in the Southern field, captivated the delegates to the 1899 General Conference session with his call for the perfect reflection of Christ in His people.

Though not as prominent as the calls for overcoming sin, Adventist leaders during this period expressed also the concept of the end-time vindication of God. I. H. Evans, in his 1900 Week of Prayer reading, used the experience of Elijah on Mount Carmel as an illustration of the end-time saints who also are preparing for translation and serve to vindicate before onlookers a God at risk. Though not sympathetic with the theological views of Jones and Waggoner, Review editor Uriah Smith, speaking in the context of the culminating struggle over the law of God, also follows them in expressing the idea that the obedience of Christ's followers, as well as Christ Himself, serves to clear God of charges of unfairly requiring obedience of fallen humans.

The period from 1888 to 1915 thus exhibits a marked development of the concept of a final generation of believers that perfectly reproduces Christ's character, and in so doing vindicates God of charges of injustice. Though E. J. Waggoner is the principal source of this development, sympathetic strands can be found in Ellen White and A. T. 
Jones, as well as lesser known leaders, and even the theological opponent of Jones and Waggoner, Uriah Smith. 


\section{CHAPTER 4}

\section{A DEVELOPED FORMULATION OF THE FINAL GENERATION,}

$1915-1937$

\section{Introduction}

In the decades after the death of Ellen White and the fading of the champions of righteousness by faith, A. T. Jones and E. J. Waggoner, M. L. Andreasen extended the final-generation concepts that E. J. Waggoner had expressed. Converted to Adventism as a young man, this independent-minded Danish immigrant made a compelling case for a critical role to be played by the last generation of humans in the overall cosmic battle between good and evil. In his first major book, The Sanctuary Service, Andreasen in 1937 outlined for the general Adventist readership the concepts that he taught Adventist ministers for many years. ${ }^{1}$ In the chapter before the last, entitled "The Last Generation," he spelled out final-generation concepts more clearly than in any of his other works.

Much space will be given in this study to a careful examination of this chapter, in order to fully understand Andreasen's concept.

Before doing so, it will be helpful to consider the general theological climate around the time that Andreasen's book was crafted. Relevant statements of a few

${ }^{1}$ M. L. Andreasen, The Sanctuary Service (Takoma Park, Washington, DC: Review and Herald, 1937). 
prominent Adventist writers will be looked at, especially in connection with the defections at the beginning of the 1930s of two Adventist leaders-Louis R. Conradi in Europe, and W. W. Fletcher in Australia. In this connection, it will be instructive to see the way in which challenges to the Adventist sanctuary doctrine were met at the time.

\section{Andreasen's Contemporaries on Eschatology and the Sanctuary}

In order to appreciate the immediate context in which Andreasen promoted lastgeneration concepts, the writings of a few prominent Adventists will be examined. One question to be addressed is whether other writers emphasized a special preparation to be made by those expecting to be translated, and if any such character perfection was important for the resolution of the cosmic controversy between good and evil. Another question is how such perceived the question of what is involved in the cleansing of the heavenly sanctuary during the antitypical day of atonement that Adventists believe began in 1844 .

\section{A. G. Daniells}

Arthur G. Daniells (1858-1935) was the longest-serving General Conference president in the history of the Seventh-day Adventist church (1901-1922). After retiring from this post, he was entrusted with the formation of what was to become the Ministerial Association. ${ }^{2}$ Among the first publications of this body, Daniells released Christ Our

${ }^{2}$ Seventh-day Adventist Encyclopedia, 2d rev. ed. (1996), s.v. "Daniells, Arthur Grosvenor"; "Ministerial Association." 
Righteousness in 1926, in which he stressed the importance of righteousness by faith. ${ }^{3}$

Without ever mentioning Jones or Waggoner by name, Daniells gathered many statements from Ellen White regarding the value of the messages that came through the 1888 Minneapolis General Conference, and expressed a desire that righteousness by faith might finally be given "free course."4 Besides not citing Jones or Waggoner, Daniells does not mention Waggoner's ideas of the role of the last generation in God's vindication, nor of the possibility of humans replicating Christ's victory over sin.

In subsequent years, Daniells continued to stress the need for a greater spirituality among ministers, while he had less concern for "certain fine points of doctrinal teaching," as he expressed it in a letter to W. W. Prescott late in 1934. In this letter, written only a year before his death, Daniells confesses that he did not realize when he was starting out in the ministry that "the doctrines we hold so confidently and earnestly ... would be eclipsed by more spiritual truths" and fuller views of Christ's teaching and ministry. While denying that he has abandoned "the fundamentals," he stresses that the "conviction that grips me is that a great change along this line must come ... in order to finish this work." Thus the motive for Daniells's concern for a greater spirituality among Adventists is that members might be "ready for translation."

\footnotetext{
${ }^{3}$ Arthur Grosvenor Daniells, Christ Our Righteousness: A Study of the Principles of Righteousness by Faith as Set Forth in the Word of God and the Writings of the Spirit of Prophecy (Washington, DC: Ministerial Association of Seventh-day Adventists, 1926).

${ }^{4}$ Ibid., 63.

${ }^{5}$ Arthur Grosvenor Daniells, Los Angeles, CA, to W. W. Prescott, Berrien Springs, MI, December 6, 1934, Box 2, Folder 2, William Warren Prescott Papers (Collection 143), CAR, 1.
} 


\section{W. W. Prescott}

William Warren Prescott (1855-1944) was a leading Adventist educator and administrator during the early twentieth century, serving as a General Conference field secretary for much of this period (1915-1937). Prescott shared the views of Jones and Waggoner as to the possibility of humans in sinful flesh replicating the victory of Christ over sin. In one of a series of articles on the book of Daniel written in 1900 for the Present Truth, while he was overseeing Adventist work in England, Prescott decried the Roman Catholic doctrine of the Immaculate Conception of the Virgin Mary, which views Christ as "far from the sinful flesh in which we live," so that "man is effectually cut off from . . the Divine life working in sinful flesh to give victory over sin."

In 1920 Prescott published The Doctrine of Christ, designed as a college and seminary textbook. This set of ninety lessons consists of summary points with Bible texts, followed by "Notes," which are quotations from Ellen White sources or other, usually unnamed, sources. The notes to Lesson 46, “The Victorious Life," under the heading "A greater heresy," cite an unnamed source which portrays "contentment with sinful imperfection as a greater heresy" than that of "sinless perfection": "It were almost better for one to overstate the possibilities of sanctification in his eager grasp after holiness, than to understate them in his complacent satisfaction with a traditional unholiness." The next note, entitled "The prevailing life," continues from the same source:

In proportion to the closeness of our abiding in him will be the completeness of our

${ }^{6}$ William Warren Prescott, "Modern Babylon Substitutes Paganism for Christianity. (Continued from Dan. vii.)," Present Truth, June 14, 1900, 375. 
deliverance from sinning. And we doubt not that there are Christians who have yielded themselves to God in such absolute surrender, and who through the upholding power of the Spirit have been so kept in that condition of surrender, that sin has not had dominion over them. ${ }^{7}$

Lesson 62 of the same book is entitled "The Needed Preparation for the Second Advent." Here Prescott teaches that to be ready for translation, "one must have a special experience," citing Enoch's pre-translation experience as it is referred to in Heb 11:5-6. It is pointed out that the latter rain is the divine provision made "for this experience of the indwelling presence" of Christ, which makes possible "a life in perfect harmony with the will of God." ${ }^{\prime}$ Prescott's emphasis on victory over sin is seen even in the title of a booklet published in the 1920s, consisting of a series of talks he gave to young people on the victorious life in Christ, and printed under the title, Victory in Christ: Ten Short Talks to Those Who Would Know the Joy of Freedom from Sin. ${ }^{9}$

Besides teaching complete overcoming of sin in those alive at the second coming of Christ, Prescott held up Job as an example of the power of God's love to keep one from falling. In the 1890s he gave a series of camp meeting talks in Australia, in which

${ }^{7}$ William Warren Prescott, The Doctrine of Christ: A Series of Bible Studies for Use in Colleges and Seminaries (Washington, DC: Review and Herald, 1920), 123. The citation is from Adoniram Judson Gordon, The Ministry of the Spirit (Philadelphia: American Baptist Publication Society, 1894), 121-122. Prescott included Gordon's work in his bibliography. This volume was republished by the Adventist-owned Review and Herald Publishing Association in 1950. Adoniram Judson Gordon, The Ministry of the Spirit (Washington, DC: Review and Herald, 1950).

${ }^{8}$ Prescott, The Doctrine of Christ, 173.

${ }^{9}$ William Warren Prescott, Victory in Christ: Ten Short Talks to Those Who Would Know the Joy of Freedom from Sin (Washington, DC: Review and Herald, 1924). In 1924 this booklet was advertised in the Advent Review and Sabbath Herald as the "seventh edition," "in about six months six editions" having been "printed and sold" (see p. 23 of the November 13 issue). 
he dealt with such topics as the Incarnation and the relationship between the law and the gospel. In his third talk, having introduced the Adventist understanding of the cosmic conflict between good and evil, declaring that the earth is a "theatre on which a drama is being enacted which is commanding the attention of the universe, ${ }^{, 10}$ Prescott turns to the case of Job. After outlining the narrative, especially Satan's charges regarding Job's motives for obedience, Prescott emphasizes that it is the power of love that kept Job loyal:

Here was a demonstration,-not simply to the few that might know of Job's case, nor to all those merely that should read of his experience, but before the whole universe,that God's power of love was sufficient to hold a man in his integrity. Though his possessions, his children, his all was gone, yet the love that God had to him, and the love that had sprung up in his heart to God, were sufficient to hold him, so that he said, "I will not give up my loyalty though I die." Job was working out before the universe how much power there was in the love of God....

... Do you not see that Job was before the Universe as a man that could be trusted to reveal the power of God's love to hold him firm in his confidence, demonstrating that there is a power in God's love sufficient to stand against trial ${ }^{11}$

Prescott continues with the story of John the Baptist, and points out that there are many unsung heroes in history who have given their lives in martyrdom: "God and His universe look on and see these witnesses to His love, see that they are not turned away from their integrity by the sophistries and machinations of Satan, but are faithful unto death." ${ }^{\prime 2}$

Continuing on the theme of the great controversy, Prescott then introduces

${ }^{10}$ William Warren Prescott, "The Kingdom of God; or the Great Controversy between Good and Evil," Bible Echo, February 17, 1896, 53.

${ }^{11}$ William Warren Prescott, "The Kingdom of God; or the Great Controversy between Good and Evil [Concluded]," Bible Echo, February 24, 1896, 60.

${ }^{12}$ Ibid. 
Christ's coming to Earth as the "climax of the controversy." At the cross, God's and Satan's ways of achieving their goals were contrasted before the onlooking universe: "All this was enacted before the universe, and how did it effect [sic] it?" Immediately following this question in the text, the next two paragraphs are preceded by the following two subheads, "God's Government Vindicated Before the Universe," and "The Cross Sealed Satan's Fate."13 Christ's death is upheld as the answer to Satan's charges. Yet Prescott reminds his hearers in the following paragraphs that "the controversy is in its height," and that "it costs something to be loyal to God now. It cost Job something; but there is a power in the love of Jesus Christ to hold." 14

Just two messages later, speaking on "The Faith of Jesus, The Commandments of God, and The Patience of the Saints," Prescott uses the epistle of James- "Ye have heard of the patience of Job" (Jas 5:11) — to link Job's experience with the "patience of the saints": "Job endured, although he could not see the reason for it. But in that trial of Job God was working out before the universe the fact that His love can keep a man when all temporal blessings are taken away." ${ }^{\prime 15}$ Here again Prescott puts the focus on Job as one who demonstrates before the onlooking universe loyalty under extreme duress. And even though he mentions Job's experience in connection with the great controversy, he shifts his attention to Christ as he speaks of God's vindication of Satan's charges. The concept that ties everything together for Prescott seems to be the love of God. Satan charged that

${ }^{13}$ Ibid.

${ }^{14}$ Ibid., 60-61.

${ }^{15}$ William Warren Prescott, "The Faith of Jesus, the Commandments of God, and the Patience of the Saints [Concluded]," Bible Echo, January 27, 1896. 
God was selfish, and also denied that Job served him out of love. But the cross demonstrated God's love, and the experience of Job and the martyrs demonstrated the keeping power of that love.

Prescott was a writer, then, contemporaneous with the early Andreasen, who shared a belief in the importance of the end-time generation gaining the victory over sin, and even pointed to Job in the context of the cosmic controversy. However, he is quick to draw attention to Christ as the great answer to Satan's accusations against God's government.

\section{Meade MacGuire}

Meade MacGuire (1875-1967), a General Conference field secretary during much of the twentieth century, joined A. G. Daniells as an associate secretary of the newly formed Ministerial Association in the mid-1920s ${ }^{16}$ MacGuire, in his new role as a spiritual leader of the Adventist ministers, published two books in the 1920s to promote a deeper Christian experience: The Life of Victory and His Cross and Mine. ${ }^{17}$ On the day before the last of the 1930 General Conference session, in a sermon entitled "The Cleansing of the Sanctuary," he called the attention of the delegates to the needed work of overcoming before Christ could return. Pointing to the cleansing of the hearts of the people in the typical Day of Atonement service, MacGuire exhorted Adventists to stop

\footnotetext{
${ }^{16}$ Seventh-day Adventist Encyclopedia, 2d rev. ed. (1996), s.v. "MacGuire, Meade"; "Ministerial Association"; Arthur Grosvenor Daniells, "The Ministerial Association," Advent Review and Sabbath Herald, June 6, 1930, 122.

${ }^{17}$ Meade MacGuire, The Life of Victory (Washington, DC: Review and Herald, 1924); idem, His Cross and Mine (Takoma Park, Washington, DC: Review and Herald, 1927).
} 
the stream of sins pouring into the heavenly sanctuary: "By the confessions of the people and the ministry of the priest a stream of sins is pouring in. As long as the stream goes up and Jesus ministers, the sanctuary cannot be cleansed and the work up there finished. It must be finished right here; it must be finished in your heart and my heart." ${ }^{18}$ MacGuire echoes A. T. Jones in his use of Dan 9:24 as applying to the end-time cleansing of the hearts of the end-time generation:

You know not how soon your name may be taken on the lips of Christ, and when He speaks your name, that ministry will be completed, that ministry of your High Priest in the heavenly sanctuary must be completed, and He must be able to announce there that $\mathrm{He}$ has been able to finish the transgression in your life, to make an end of sins in your life, and that He has made a final atonement, or reconciliation, for your sins, and has brought into your heart everlasting righteousness. ${ }^{19}$

MacGuire concludes his message with a testimony of his conviction that God is able to rid him of sin, and a prayer for it to be so:

I want Him to make an end of sins in my life. I cannot, but I know that Jesus Christ is able to bring all sins in my life to an end. Glory be to His name! I believe in that Saviour who is able to come into human flesh and live His divine life again in humanity, and make an end of sins and produce everlasting righteousness in a poor, weak, helpless man....

... O Lord, make an end of sin in my life, make reconciliation for the last iniquity, and bring in everlasting righteousness, that righteousness of Jesus, which is the wedding garment we must all have on before the Holy Spirit is poured out.

Thus MacGuire represents a continuing conviction among mainstream Adventists at the beginning of the 1930s that a work of eradication of sinful behavior was needed among them before Christ could finish His work in the heavenly sanctuary. However, he alludes to some opposition to the idea of overcoming sin when he explains, "It seems to

${ }^{18}$ Meade MacGuire, "The Cleansing of the Sanctuary," Advent Review and Sabbath Herald, June 26, 1930, 9.

${ }^{19}$ Ibid. 
me very necessary to put emphasis upon this, because there seem so many who cannot grasp the idea that there is any possibility of ever stopping our habitual sins." But he maintained that, although the OT sanctuary service "never made anybody perfect" or brought about "complete deliverance," "it is possible for men through Christ's ministry in the sanctuary above to be perfected, perfected forever" [Heb 10:1-18]. ${ }^{20}$

\section{The 1930s Focus on the Sanctuary}

At the beginning of the 1930s the Adventist church was stunned by the defections of two prominent overseas leaders, Louis R. Conradi in Europe and W. W. Fletcher in Australia. Both had serious reservations about the Adventist sanctuary doctrine. This resulted in a vigorous campaign on the part of the denomination to defend the traditional view. Articles began to appear frequently in the church's journals, presenting the Adventist positions on the sanctuary, the atonement, and the investigative judgment. ${ }^{21}$ It will be helpful in understanding M. L. Andreasen's writing on the sanctuary, to briefly review what Adventist leaders were saying about the sanctuary in the context of the Fletcher and Conradi defections.

\section{H. Watson}

Charles H. Watson (1877-1962) was president of the General Conference from

\section{${ }^{20}$ Ibid.}

${ }^{21}$ For details of Fletcher's defection and the vigorous response of the denominational presses, see Paul M. Evans, "Seventh-day Adventist Views of the Sanctuary and the Atonement, 1920-1936" (term paper, Andrews University, 2004), CAR, 1-9. It is interesting to note that the chief defenders of the sanctuary doctrine were General Conference and union administrators, and not Ministerial Association secretaries or Bible teachers. See pp. 184-185, 192-193, 195 above. 
1930 until 1936, during the height of the turmoil surrounding the departure of Conradi and Fletcher. He had served previously as president of the Australasian Union Conference, in which Fletcher had been a college teacher and union office administrator. ${ }^{22}$ In 1934 Watson published a 224-page volume, The Atoning Work of Christ, in which he attempted to show the difference between Christ's sacrifice on the cross and His priestly ministry in the heavenly sanctuary. The following year, key chapters from the book were reprinted as articles in the Advent Review and Sabbath Herald. $^{23}$

Watson broke somewhat from what Adventists had been saying about the atonement, using the word "reconciliation" for what Christ accomplished on the cross for the whole world. ${ }^{24}$ He denied that this implied universal salvation, by likening it to the continual burnt offering of the typical service, which was a provision for all the people. The sin offering, on the other hand, expressed one's acceptance of the provision. Thus, in Watson's view, the reconciliation provided at the cross was not the atonement, but rather made possible atonement through the intercession of Christ in the heavenly sanctuary. ${ }^{25}$

\footnotetext{
${ }^{22}$ Seventh-day Adventist Encyclopedia, 2d rev. ed. (1996), s.v. "Watson, Charles Henry"; "Fletcher, William Warde."

${ }^{23}$ Charles Henry Watson, The Atoning Work of Christ: His Sacrifice and Priestly Ministry (Takoma Park, Washington, DC: Review and Herald, 1934); idem, "The Sanctuary in Heaven," Advent Review and Sabbath Herald, February 21, 1935; idem, "The Most Holy Place," Advent Review and Sabbath Herald, February 28, 1935; idem, "The Investigative Judgment," Advent Review and Sabbath Herald, March 7, 1935; idem, "The Cleansing of the Sanctuary," Advent Review and Sabbath Herald, March 14, 1935.

${ }^{24}$ Watson, Atoning Work of Christ, 64.

${ }^{25}$ Ibid., $79-80$.
} 
In reviewing the arguments on both sides of the debate, it is easy to come to the conclusion that it was all a matter of terminology and definitions, rather than of substance, especially when one considers the question of whether or not atonement was made at the cross. The questions seem more substantive, however, when the problem of the relationship of obedience to atonement is considered — especially an end-time final atonement connected with the cleansing of the sanctuary. Watson devotes the first few chapters of his book to obedience, pointing out that in God's sight obedience is better than sacrifice; that is, the paying of the penalty of our disobedience "is but preliminary to making us obedient." ${ }^{26}$ When he discusses the Most Holy Place ministry of Christ, though, Watson was reticent to place too much emphasis on the significance of humans overcoming sin. Adventists have maintained that sins are not blotted out until the sanctuary is cleansed on the antitypical end-time Day of Atonement. Rather than joining those (such as Jones and Waggoner) who see this as an eradication of acts of sin from the life, Watson argues rather for a deep confession of hidden sins. For Watson, the final atonement has "a very peculiar value when we recognize that wrongs which we have done unconsciously and therefore have never confessed leave us under the condemnation of the law. ${ }^{27}$ In this view the sanctuary is cleansed when all sins are brought to light and are confessed. Also, rather than speaking of an end-time perfection of the saints, Watson rather emphasizes that it is on account of their union with God that they stand in the time

${ }^{26}$ Ibid., 38, 78 .

${ }^{27}$ Charles Henry Watson, Wahroonga, New South Wales, to Our Field Workers in the Australasian Division, TLS (photocopy), March 27, 1930, Fletcher et al., Correspondence, 1930-1946 on the sanctuary question and investigative judgment with E. S. Ballenger, L. R. Conradi, and others, CAR, 2. 
of trouble without a mediator:

During this time we must live before God without an intercessor. Some have the mistaken idea that then the righteous must depend on the perfection of their own lives to stand until Christ appears. This is in no sense true. The apostle John has made it clear that we shall have boldness in that day, not by anything of our own, and not by anything we have done, but by being in God and having God in us. ${ }^{28}$

\section{W. H. Branson}

William H. Branson (1887-1961) served as a vice-president of the General Conference during the 1930s, and would eventually become General Conference president in the early 1950s. Besides his In Defense of the Faith: The Truth About Seventh-day Adventists, A Reply to Canright, ${ }^{29}$ published in 1933, Branson wrote a series of articles in the Signs of the Times in 1934, which were expanded the next year to become The Atonement in the Light of God's Sanctuaries. ${ }^{30}$ Similarly to Watson, Branson sees restoration of obedience as the goal in the atoning work of Christ. Justification is seen as providing the believer with a clean page on which must be written

${ }^{28}$ Watson, Atoning Work of Christ, 214.

${ }^{29}$ Dudley M. Canright was an Adventist minister and writer who had defected in the 1880s, and had sharply attacked a number of Adventist views in Seventh-day Adventism Renounced (New York: Fleming H. Revell, 1889). See Seventh-day Adventist Encyclopedia, 2d rev. ed. (1996), s.v. "Canright, Dudley Marvin."

${ }^{30}$ William H. Branson, In Defense of the Faith: The Truth About Seventh-day Adventists: A Reply to Canright (Takoma Park, Washington, DC: Review and Herald, 1933); idem, "The Sanctuaries of God," Signs of the Times, July 24, 1934; idem, "Christ's Ministry in the First Apartment of the Heavenly Sanctuary," Signs of the Times, August 14, 1934; idem, "The Cleansing of the Earthly Sanctuary," Signs of the Times, August 21, 1934; idem, "The Cleansing of the Heavenly Sanctuary," Signs of the Times, August 28, 1934; idem, The Atonement in the Light of God's Sanctuaries (Mountain View, CA: Pacific Press, 1935). 
a life of obedience in order to "retain the ground ... through faith." 31 And he concludes this work on the atonement by telling how "the Christ of the atonement" "fully restores His image" in sinners by dwelling in them and bringing His "power to bear upon the weak tendencies" of their nature. This is His "crowning work.",32

In dealing with the ministry of Christ in the Most Holy Place, and identifying the criteria for successfully passing the investigative judgment, Branson takes somewhat the middle ground. While some hold that the test may be passed "if we keep our sins confessed every day" or "repent of every sin," 33 Branson warned that one's life would be measured against the law, declaring that "the beautiful fruits of righteousness" appearing in the life "will destroy all fear of the judgment." ${ }^{34}$ Lest one become discouraged, though, Branson admits the validity of what are expressed as two different criteria for passing the judgment. He asserts that a person may be acquitted in the judgment "if it is discovered . . . that, through faith in Jesus Christ, he has faithfully kept the law's requirements, or that, failing this, he accepts Christ's righteousness as a covering for his failure." 35

${ }^{31}$ Branson, The Atonement in the Light of God's Sanctuaries, 89.

${ }^{32}$ Ibid., 94-95.

${ }^{33}$ Walter E. Read, "Studies on the Sanctuary - No. 9: The Hour of Judgment," Advent Review and Sabbath Herald, October 27, 1932, 10; John Lewis Shuler, The Great Judgment Day: In the Light of the Sanctuary Service (Washington, DC: Review and Herald, 1923), 116. The article by northern Europe leader Walter Read was the ninth in a series of 10 articles on the sanctuary.

${ }^{34}$ Branson, The Atonement in the Light of God's Sanctuaries, 75, 80.

${ }^{35}$ Ibid., 75 . 
But clearly the goal in Branson's view is complete victory over sin. In the last chapter of the book, entitled "The Lord Our Righteousness," he looks forward to a "higher, holier experience," something more than "pardon for past sins and justification." Christ's imparted righteousness "actually touches our flesh and brings its actions into harmony with God's law; the nature is changed." Branson concludes by asking his readers, "Will you tell Him that you are willing that He should live His life of perfect obedience to the moral law of God in your flesh?"36

\section{Views on the Meaning of the Antitypical Day of Atonement}

The focus of Watson's and Branson's critiques of Adventist detractors is to show the validity of the two-phase Christian-era ministry of Christ. Thus, much attention is given to explaining why any atonement made on the cross is not enough for salvation — why the blood must be applied individually for salvation to be effected. More than this, it is the task of Adventist apologists to explain the need for a special, end-time work of atonement corresponding to the Day of Atonement of the typical service. Watson summarizes the work involved in a distinct, second phase of Christ's sanctuary ministry:

When the investigative phase of the judgment is finished, and the sins of God's people have been blotted from the books of records in heaven, and when our High Priest has with His own blood cleansed or justified the sanctuary, then He will put the sins that have defiled the sanctuary upon their originator, whose power will be broken, whose reign will be ended, and who will finally perish in the fires that purify the earth. ${ }^{37}$

\footnotetext{
${ }^{36}$ Ibid., 91, 95-96.

${ }^{37}$ Watson, Atoning Work of Christ, 179.
} 
In this sense the Day of Atonement services are seen as related to both questions of salvation ("the sins of God's people have been blotted from the books of records in heaven") and questions of theodicy, that is, questions regarding God's justice and goodness in relation to His handling of the controversy between good and evil ("when our High Priest has with His own blood cleansed or justified the sanctuary, then He will put the sins that have defiled the sanctuary upon their originator").

The first set of questions, related to salvation, Watson dealt with under the head of the investigative judgment and the blotting out of sin. The judgment is seen as a work of going through the record books to determine the reward or punishment that each person will receive. "Those whose names are in the Lamb's book of life will be rewarded with eternal life. Those whose names are not in the book of life will be cast into the lake of fire." ${ }^{38}$ The reward of eternal life is given to those whose sins are blotted out in this final atonement process. If one's sins are not blotted out at this time, then the person's name is blotted out of the book of life. ${ }^{39}$

Watson deals with questions related to theodicy in his chapter on the Most Holy Place. In trying to explain how an apartment of the heavenly sanctuary can be called Most Holy for some other reason than that God's presence is there manifested, he proposes that one reason it is designated "most holy" is that it is there that the great controversy is resolved: "It is there, in the most holy place, that the goodness, justice, truth, mercy, love,

${ }^{38}$ Ibid., 168.

${ }^{39}$ Ibid., 175. Adventists do not believe in the doctrine of perseverance. "The mere fact that one at some time in life has become a Christian and has united with the church is no guaranty of his final salvation." William H. Branson, "A Time of Cleansing and of Judgment," Signs of the Times, September 11, 1934, 5. 
and holiness of God will be most fully revealed in the completeness of His dealings with His creatures. .. . The holiness of God's character there will be put beyond question forever." 40 Watson opens this chapter, "The Most Holy Place," with these words: "In the great controversy between Christ and Satan, the holiness of God is one of the matters in dispute. This, therefore, is one of the most important of the many things that God has purposed shall be made manifest by His great work of atonement." ${ }^{41}$ However, in the progressive unfolding of the "justice and mercy and goodness of God" and also of the "real character of Satan" in the controversy, Watson emphasizes the "death of Christ" as the moment when "the character of Satan was fully revealed." Two pages later, though, the investigative judgment is depicted as a work that causes "God's holiness" to be "so clearly manifest to His creatures that it will never again be questioned." ${ }^{2}$ Thus Watson places significance on not only the salvific dimensions of the end-time Day of Atonement ministry of Christ, but also on its significance for the vindication of God's holiness.

The clearest link between the Day of Atonement service and an end-time vindication of God's goodness is seen in the ritual relating to the scapegoat. This is because, as Adventist writers stress in their efforts to deny Satan any role in their salvation, these ceremonies occur after the sanctuary and people have been reconciled, and all atonement has been made. "The scapegoat does not come into the plan at all until

${ }^{40}$ Watson, Atoning Work of Christ, 160.

${ }^{41}$ Ibid., 159. It seems that Watson chooses the word "holiness" in order to add weight to his argument for naming a room in the sanctuary "Most Holy" because of what occurs there, rather than by the holiness of the One occupying it.

${ }^{42}$ Ibid., 160, 162. 
the atonement for the sins of God's people is completed," and no blood is shed by the scapegoat, showing that Satan's sin-bearing is not an atonement for sin, but rather shows responsibility for $\sin .{ }^{43}$ Therefore, since the scapegoat has no salvific role, it has a clear theodical role. But, as seen in Watson's comments related to the Most Holy Place resolution of the great controversy, his focus is on the Day of Atonement as a whole, and not merely the scapegoat ritual, when theodical concerns are noted.

It seems that Adventist writers of this period, in their attempt to defend the Adventist sanctuary doctrine, gave prominence to theodical concerns primarily in the process of defending themselves against the charges of their critics that the doctrine seemed to deviate from basic Christian thought. The Day of Atonement is seen as the time when God's holiness is established beyond question. But this is pointed out by Watson in the process of showing how the second apartment of the sanctuary can be termed the Most Holy Place even if God is sometimes removed from thence. And the scapegoat ceremony is depicted as portraying the final riddance of sin from the universe. But this, too, is stated in the context of defending the Adventist position from charges that it makes Satan their savior. Thus the rather unique Adventist view of the cosmic conflict between good and evil, and its resolution at the end of salvation history, is given prominence in the process of defending it from attack. This would change very soon as one Adventist writer came forth with a very bold and unapologetic portrayal of what he viewed as the deeper meaning of the Adventist sanctuary doctrine, especially as it relates

\footnotetext{
${ }^{43}$ Walter E. Read, "Studies on the Sanctuary - No. 8: The Final Disposal of Sin," Advent Review and Sabbath Herald, October 20, 1932, 9; Watson, Atoning Work of Christ, 149-150; Branson, "The Cleansing of the Earthly Sanctuary," 3. See also idem, In Defense of the Faith, 228; idem, "The Scapegoat," Watchman, February 1929, 34.
} 
to the vindication of God at the end of time. This portrayal, and an analysis of it, will be the focus of the balance of this study.

\section{Significant Aspects of Andreasen's Biography}

Milian Lauritz Andreasen (1876-1962) was a leading Seventh-day Adventist administrator and educator during the first half of the twentieth century. From the time of his ordination to the ministry in 1902, except for his first seven years, he served as a conference president, college Bible teacher, college president, seminary professor, and General Conference field secretary, until his retirement in 1950. The Seventh-day Adventist Encyclopedia notes that he was "considered an authority" on the sanctuary doctrine. ${ }^{44}$ He authored many articles and books, the most important for this study being his first book, The Sanctuary Service, published in 1937.

Andreasen wrote a partial autobiography, which is referenced frequently in Virginia Steinweg's Without Fear or Favor: The Life of M. L. Andreasen. ${ }^{45}$ From this, along with many manuscripts and interviews, Steinweg has produced an interesting overview of Andreasen's life. Several details are important for this study.

Perhaps the most important fact concerning M. L. Andreasen's background is that he was converted to the Seventh-day Adventist faith after reading through Uriah Smith's Daniel and the Revelation, which convinced him of the Sabbath and other Adventist beliefs. As a teenager, he had left his immigrant parents' home in Winnipeg, and

\footnotetext{
${ }^{44}$ Seventh-day Adventist Encyclopedia, 2d rev. ed. (1996), s.v. "Andreasen, Milian Lauritz."

${ }^{45}$ Steinweg, Without Fear or Favor.
} 
emigrated to Council Bluffs, Iowa. After having begun to keep the Sabbath by himself, against his best instincts he hesitatingly started to attend the local Seventh-day Adventist church ${ }^{46}$ From Steinweg's mosaic, Andreasen appears on the Adventist scene as a rugged individualist who had already formed the habit of thinking things through for himself. He had no natural connections or obligations inside the denomination, and seems to have maintained throughout his career a touch of the somewhat irreverent skepticism of his youth. ${ }^{47}$ As an example of his questioning mental attitude, it took a visit to Elmshaven, about the year 1909, to convince him that Ellen White, with a very limited education, had actually written the books published under her name. ${ }^{48}$

Besides being an independent thinker, Andreasen early became quite familiar with many of the inside workings and theological questions of the Adventist denomination. In College View, Nebraska, where workers would occasionally gather, the young convert Andreasen was allowed to sit in on discussions, which frequently revolved around the 1888 General Conference session. J. H. Morrison, one of the leading opponents of Jones and Waggoner at Minneapolis and afterward, lived in Lincoln, and many of those who had opposed Ellen White at the conference joined in the discussions. ${ }^{49}$ Then, while a student at Battle Creek College, he met men like A. T. Jones, John Harvey Kellogg, and Uriah Smith. He spent hours discussing theology with Jones, comparing notes with what

\footnotetext{
${ }^{46}$ Ibid., 29-34.

${ }^{47}$ Ibid., 11-22.

${ }^{48}$ Ibid., 73-78.

${ }^{49}$ Ibid., 42-44, 46-47.
} 
he had heard previously from his opponents. These meetings allowed Andreasen to obtain "firsthand information of many things in regard to controversies pending and in the process of solution."${ }^{90}$

Andreasen also was privileged to be an (uninvited) observer at the hearing of A. F. Ballenger, who was ousted from the ministry over his sanctuary views, during the 1905 General Conference session; during this time he also met personally with Ballenger and listened to him explain both sides of the sanctuary question. ${ }^{51}$ Newly chosen to be president of Union College, in Lincoln, Nebraska, Andreasen in 1931 served on the General Conference-appointed committee that met in nearby Omaha to hear Louis Conradi explain his views. Shortly after the hearings Conradi left the church over the Adventist sanctuary doctrine and other teachings. ${ }^{52}$ These first-hand experiences in connection with problems over the Adventist sanctuary teaching would have enhanced Andreasen's understanding of the perceived weaknesses and the unique aspects of the sanctuary doctrine of Seventh-day Adventists.

Another significant event in Andreasen's theological development was his visit to Ellen White's home around the year 1909, shortly before he became head of the newly planned Danish-Norwegian Seminary in Minnesota, which would train young men for the ministry. Feeling that he needed to find out the truth for himself, and not depend on

${ }^{50}$ Ibid., 51-53. This is from Andreasen's unpublished autobiography.

${ }^{51}$ Ibid., 58-60.

52“'Statement on Conradi Hearing: Hotel Rome, Omaha, Nebraska, Oct. 13-16, 1931," by committee appointed by the General Conference Committee to hear the views of L. R. Conradi; C. H. Watson, chairman, TD (photocopy), CAR. 
"secondary authorities, however good they might appear to be," Andreasen decided to find out for himself the extent to which White was responsible for the content of her published works. He had assumed that her assistants crafted the language from her rough sketches, whether written or dictated, but was surprised, having been given free access to the vault where her manuscripts were kept, to see written in her own handwriting so many of the statements he had chosen to investigate. He was convinced that "her writings were produced under the guidance of God." ${ }^{53}$ The writings of Ellen White would exert a strong influence over Andreasen's views in succeeding years.

Finally, Andreasen was one of the foremost promoters of higher education in the denomination. While serving as head of the Bible department at Union College from 1918 to 1922, he finished a B.A. and earned an M.A. in American history from the University of Nebraska, against Adventist distrust of academic degrees. ${ }^{54}$ He later accepted a position as president of the Minnesota conference with the idea of continuing his studies at the University of Minnesota, but his dream of further study was not realized. ${ }^{55}$ Andreasen was president of Union College from 1931-1938, during which

\footnotetext{
${ }^{53}$ M. L. Andreasen, "The Spirit of Prophecy - Particularly the Account of Elder M.L. Andreasen's Personal Experience with Ellen White," TMs (photocopy), [196-?], CAR. This may be found in Steinweg, Without Fear or Favor, 74-78.

${ }^{54}$ For background on Adventist aversion to academic degrees in the early twentieth century, see George R. Knight, Myths in Adventism (Hagerstown, MD: Review and Herald, 1985), 38-40.

${ }^{55}$ Steinweg, Without Fear or Favor, 92-99. It is interesting that from 1922 to 1924, prior to moving to Minnesota, Andreasen had found it difficult to teach the Bible at Washington Missionary College "the way they teach it here." Steinweg reports that Andreasen confided to a colleague at a teachers' convention, "My conscience won't permit me to teach Bible any longer" (p. 96).
} 
time it became one of the first Adventist colleges to be accredited by a regional accrediting association, due in part to Andreasen's prodding. ${ }^{56}$ Andreasen was also in the middle of the denomination's first steps towards providing graduate studies, in the form of the Advanced Bible School, a summer school for ministers and Bible teachers held at Pacific Union College from 1934 to 1936 . The school was moved to Washington, DC, to become a permanent theological seminary, and Andreasen left Union College in 1938 to become one of the seminary's regular faculty. ${ }^{57}$ Now in his $60 \mathrm{~s}$, Andreasen had satisfied church officials' questions about whether he was "orthodox," "safe" to teach young ministers. For eleven years Andreasen taught at the seminary; during many of those years he worked as a General Conference field secretary. ${ }^{58}$

Andreasen was thus well-placed both to be influenced by a previous generation of Adventist leaders and to influence the oncoming generation of ministers and teachers. Being personally acquainted with such leaders as Ellen White, A. T. Jones, J. H. Morrison, Uriah Smith, John H. Kellogg, A. F. Ballenger, and Louis Conradi, he had an intimate knowledge of the key issues in Adventist theology, while he maintained an independent, inquisitive frame of mind that was an advantage to him in his career as an educator. His years as a successful conference and school administrator led him to be seen as

${ }^{56}$ Ibid., 134-138.

${ }^{57}$ Ibid., 144-150; Seventh-day Adventist Encyclopedia, 2d rev. ed. (1996), s.v. "Pacific Union College."

${ }^{58}$ Steinweg, Without Fear or Favor, 147, 151. 
trustworthy by others, and he was entrusted with a leading role in the budding denominational seminary.

\section{Andreasen's Views on the Final Generation}

It was in 1937, as Andreasen was about to make the move to Washington, DC, as a full-time seminary professor, that he published The Sanctuary Service, in which he outlined very clearly his understanding of the importance of the last generation living on earth at the end of time. Though this was the most comprehensive statement of his views, Andreasen had previously published some of his final-generation concepts in a few articles and a series of Sabbath School lessons, beginning in 1924, the year he was elected president of the Minnesota conference. Dwight Eric Haynes, in his 1990 M.A. thesis, set about to describe the development of Andreasen's final-generation concepts up through 1937. Though the few exhibits available show an increasingly fuller expression over time, the main components of Andreasen's theology seem to have changed little. ${ }^{59}$ Thus this study will utilize a synchronic, rather than a diachronic, approach to describing Andreasen's concepts. Components of Andreasen's final-generation theology will be discussed in this chapter, and compared with other writers in the next chapter, under two broad headings: (1) challenge and vindication; and (2) salvation as complete victory over sin. Haynes identified six "axioms" that "constitute the developed framework of Andreasenian theology: (1) the motif of human ability to overcome sin; (2) the motif of hatred for sin; (3) the motif of eschatological patience; (4) the motif of challenge; (5) the

\footnotetext{
${ }^{59}$ Haynes, "The Final Generation," 90-91.
} 
motif of dependence; and (6) the motif of vindication. ${ }^{90}$ The last four of these six will be discussed under the first heading of this study, challenge and vindication. The first two of Haynes's six “axioms" will be subsumed under this study's second broad category, salvation as complete victory over sin.

\section{Challenge and Vindication}

The most salient aspects of Andreasen's theology of the last generation deal with the vindication of God in the context of the challenges coming from Satan, the highest being in the created order. The last generation is understood as playing a crucial role in clearing God of the charges that Lucifer has leveled against His character and law. God is seen to be on trial, as He subjects Himself to the judgment of His creatures, who must make a decision as to the validity of Satan's claims. The stability of God's universal rule, which is based on the willing obedience of created intelligences, is considered to be dependent on the confidence of His creatures in His justice and benevolence. In his teaching on the final generation, Andreasen highlights the role of end-time witnesses to God's goodness and justice, without which witness, God's case will not be successfully resolved.

\section{Satan's Challenge before the Cross}

The Adventist perspective on the cosmic conflict between good and evil lies at the foundation of Andreasen's final-generation theology. Satan accuses God of being unfair in requiring obedience to a law that is impossible to keep. Near the beginning of chapter

${ }^{60}$ Ibid., 21. 
21 of The Sanctuary Service, entitled "The Last Generation," Andreasen asserts that the last generation "clears [God] of any and all charges which Satan has placed against Him. ${ }^{\prime 61}$ To understand these charges, Andreasen takes six pages to review the origin of sin and rebellion in heaven, and its extension to this earth, especially in connection with the life and death of Christ. In the first paragraph of this section, Andreasen presents Lucifer as overcome by a desire to depose God: "Where God sat, Satan would sit. God accepted the challenge." ${ }^{92}$

Later in the same chapter, Andreasen paints a grim picture of the situation in heaven when Lucifer rebelled:

A serious situation arose in heaven when Satan made his charges against God. The accusations in reality constituted an impeachment. Many of the angels believed the charges. They ranged themselves on the side of the accuser. One third of the angels - and that must have been millions - faced God with their leader, the highest among the angels, Lucifer. It was no small crisis. It threatened the very existence of God's government. How should God deal with it? ${ }^{63}$

The charges are portrayed in the context of a court scene in which "God Himself is the accused and is on trial. He has been charged with injustice, with requiring His creatures to do that which they cannot do, and yet punishing them for not doing it. The law is the specific point of attack, but the law being merely a transcript of God's character, it is God and His character that are the points at issue. ${ }^{\prime 4}$ Thus Andreasen expresses Satan's

${ }^{61}$ Andreasen, The Sanctuary Service, 303. All references to this work will be to the revised edition, which is very similar to the 1937 edition, but with different pagination.

${ }^{62}$ Ibid., 304.

${ }^{63}$ Ibid., 315.

${ }^{64}$ Ibid., 316. 
charges in terms of questioning God's justice in punishing sinners for not keeping a law that was impossible for them to keep.

Thus the existence of God's government was threatened, and it seems as though God was forced to accept the challenge, according to some of Andreasen's statements. For example, Satan is seen actually setting up his throne and establishing his government in heaven, so that the angels were forced to decide for or against his rule. After the ensuing battle Satan was "defeated," but not "destroyed." "He had declared God's government at fault" and "made claim to greater wisdom or justice than God." Note how Andreasen paints the divine predicament: "God could ill afford not to give Satan an opportunity to demonstrate his theories. To remove every doubt in the minds of the angels — and later of man — God must let Satan go on with his work." ${ }^{955}$ However, Andreasen also seems to desire to maintain God's sovereignty when he writes elsewhere that the decision to allow Satan to demonstrate his principles was not a forced one:

We would not give the impression, however, that God was forced to do what $\mathrm{He}$ did. Rather, what He did was exactly what He wanted to do, regardless of the wishes of Satan. After sin had come, unwelcome though it was, God wanted to have its true nature revealed. He was not only willing, but anxious, that it be given full opportunity to show itself. ... God is anxious that Satan be given a chance to show what he can do. ${ }^{66}$

God is thus seen as willingly affording the devil a chance to show what his government would do, in order to remove all cause for doubt among the created intelligences.

${ }^{65}$ Ibid., 304-305.

${ }^{66} \mathrm{M}$. L. Andreasen, The Faith of Jesus and the Commandments of God (Washington, DC: Review and Herald, 1939), 558; idem, The Sabbath: Which Day and Why? (Washington, DC: Review and Herald, 1942; reprint, paperback ed., 1969), 292. 


\section{Christ Answers the Challenge}

To Satan's charge that it is unjust for God to require obedience to a law which it is impossible to obey, Andreasen holds up Christ as God's answer. In his first published work, the Sabbath School lesson quarterly for the fourth quarter of 1924, Andreasen pointed out in the second lesson of the quarter, "Righteousness by Faith," that "Christ kept the law, and thereby demonstrated that it was possible for man to obey God." ${ }^{67}$ In The Sanctuary Service, he also noted that "when Christ died on the cross He had demonstrated in His life the possibility of keeping the law." Interestingly, Andreasen pointed out that Satan did not need to entice Christ to sin. If only He could be made to fall back on His divine power, Satan would ruin God's "demonstration" of the possibility of human obedience:

Satan had not succeeded in leading Christ into sin. Possibly he did not expect to be able to do that. But if he could have induced Christ to use His divine power to save Himself, He would have accomplished much. Had Christ done so, Satan could have claimed that this invalidated the demonstration God intended to make, namely, that it was possible for men to keep the law. ${ }^{68}$

Andreasen makes it clear that even though Satan was "baffled," and "could not understand" Christ's persistent selflessness, he "knew that when Christ died without his having been able to make Him sin, his own doom was sealed."69 Thus, at least in this

\footnotetext{
${ }^{67}$ M. L. Andreasen, "The Christian Life," Sabbath School Lesson Quarterly,
} Fourth Quarter, 1924, 5-6. Authorship of this quarterly is attributed to Andreasen by Steinweg (Without Fear or Favor, 98).

${ }^{68}$ Andreasen, The Sanctuary Service, 309.

${ }^{69}$ Ibid., 310. 
context, Andreasen upholds the work of Christ as refuting the charges of Satan that God's law was impossible to keep.

\section{Renewed Challenge after the Cross}

The victory that Andreasen understands Christ as having gained, though, was not enough to completely stop the mouth of His challenger. The next paragraph of the narrative in this key chapter of The Sanctuary Service identifies the basis for a renewed challenge: "But Satan did not give up. He had failed in his conflict with Christ, but he might yet succeed with men. . . If he could overcome them he might not be defeated."70 Previously in this chapter, in the course of describing Satan's demonstration, Andreasen pointed out that "even then [after Christ was crucified] God did not destroy Satan. The demonstration must be completed." Andreasen argues that "only when the last events are taking place" will there "remain no doubt in the mind of anyone that, had he the power, Satan would . . . murder the Son of God, and establish a kingdom of violence." ${ }^{71}$ In Andreasen's view, it seems quite clear that it was not only Satan's wishful thinking, but a real possibility, that Satan still had a chance to triumph.

Haynes helpfully points out, in his description of Andreasen's last-generation theology, what may be a possible source for this concept of a second chance for Satan. Two Ellen White statements that use the word "triumph" seem to create a foundation for Andreasen. In portraying the internal struggle of Christ with "fierce and subtle temptations" as He made His last journey to Jerusalem, where He knew He would be

\footnotetext{
${ }^{70}$ Ibid.

${ }^{71}$ Ibid., 306.
} 
crucified, White states: "Had Jesus yielded for a moment, had He changed His course in the least particular to save Himself, Satan's agencies would have triumphed, and the world would have been lost." ${ }^{\prime 2}$ Then, in describing the post-probationary time of trouble, she says that Satan "numbers the world as his subjects; but the little company who keep the commandments of God are resisting his supremacy. If he could blot them from the earth, his triumph would be complete." ${ }^{.73}$ Haynes contends that Andreasen equated "triumph" in these two statements, so that if Satan could blot the 144,000 from the earth, it would result in his triumph, the loss of the world, and the failure of the plan of salvation. ${ }^{74}$

This concept of continuing high stakes in the cosmic conflict is clear from Andreasen's rendition of closing events in his 1939 The Faith of Jesus and the Commandments of God, in which he asks, "Just what is at stake in this controversy? For Satan, everything; for God's people, everything; for God, very much." That God does not also have "everything" at stake may indicate that God cannot be destroyed even if $\mathrm{He}$ should be unable to completely refute Satan's challenge. In any case, it is clear that Andreasen sees the last struggle as having serious consequences: "The final controversy will doubtless be the crowning struggle of the ages. Satan knows that it will be his last opportunity, and that if this battle is lost, all is lost." ${ }^{75}$ And in The Sanctuary Service

${ }^{72}$ E. G. White, Desire of Ages, 486.

${ }^{73}$ E. G. White, Great Controversy, 618.

${ }^{74}$ Haynes, "The Final Generation," 32-33.

${ }^{75}$ Andreasen, The Faith of Jesus and the Commandments of God, 557. 
Andreasen states that a positive outcome of the controversy "hinges on the production of one or more who keep the commandments of God. On this God has staked His government."

If one is inclined to cite the example of Christ as an example of a Man who kept the law, Andreasen responded in his 1948 commentary on Hebrews:

Christ had demonstrated in His own body that it was possible to be completely victorious over sin; but the question would naturally arise as to whether His victory was merely a singular demonstration made possible by His unique relation to the Father or whether others could do what He had done? Could men overcome as He had overcome? ${ }^{77}$

As to other great examples of obedience found in the Bible, Andreasen answers by depicting Satan as scorning this evidence:

While it is true that many from time to time have dedicated their lives to God and lived without $\sin$ for periods of time, Satan claims that these are special cases, as was Job's case, and do not come under the ordinary rules. He demands a clear-cut case where there can be no doubt, and where God has not interfered. Can such an instance be produced?

... Satan has claimed that those who in the past have served God have done so from mercenary motives, that God has pampered them, and that he, Satan, has not had free access to them. If he were given full permission to press his case, they also would be won over. But he charges that God is afraid to let him do this. "Give me a fair chance," Satan says, "and I will win out."78

Thus the renewed challenge of Satan is, "No one can keep the law. It is impossible. If there be any that can do it or that have done it, show them to me. Where are they that

${ }^{76}$ Andreasen, The Sanctuary Service, 316.

${ }^{77}$ Andreasen, The Book of Hebrews, 58.

${ }^{78}$ Andreasen, The Sanctuary Service, 316. Andreasen does not speak to the issue of whether Christ's human nature was different from that of other humans, since the nature of Christ had not yet become a topic of discussion among Adventists. Otherwise, it seems he likely would have portrayed Satan claiming that Christ's example was a sham. 
keep the commandments?"' Andreasen reveals the depth of this challenge, as he perceives it, in the following paragraph: "Let us say it reverently: God must meet Satan's challenge. ${ }^{.79}$ Even if Andreasen would perhaps argue against the idea that God is forced to meet the challenge, he clearly shows his conviction that God has "very much" at stake in the last-day struggle. ${ }^{80}$

\section{Job as a Type of the Final Generation}

Thus far it is clear that Andreasen perceives an end-time struggle similar to what occurred in the life of Christ, with Satan trying his utmost to cause one or more persons to waver in their loyalty to God in order to frustrate and upset the plans of God. Much of Andreasen's expressions are couched in the language of a court trial, where there is an accusation, evidence is brought forth and weighed, the testimony of witnesses is heard, and a jury makes a decision regarding the validity of the accusations. The word "demonstration" is also very common whenever Andreasen deals with the great controversy theme, in which the history of Planet Earth is regarded as an opportunity for both God and Satan to show the principles of their respective systems.

One key paradigm Andreasen uses in building his case for God's dependence on human witnesses for refuting Satan's challenge is the story of Job. Besides the obvious similarities between Job's experience and that of the last generation, as Andreasen understands it, a connection is made by way of the expressions "the patience of the saints" in Rev 14:12 and the "patience of Job" in Jas 5:11. In his 1924 Sabbath School

\footnotetext{
${ }^{79}$ Ibid., 310-311.

${ }^{80}$ Andreasen, The Faith of Jesus and the Commandments of God, 557.
} 
quarterly on "The Christian Life," Andreasen refers to Jas 5:11 in stressing the importance of patience for God's end-time people, noting that "its real meaning is to endure," as seen in the experience of Job, who was "eminently successful" in this sense. In the same study Andreasen reasons that since "tribulation works patience" (cf. Jas 1:3), and since "the remnant church is noted for its patience" (cf. Rev 14:12), "it follows naturally that the remnant church will have special trials and tribulations." ${ }^{\circledR 81}$ Two years later, at the General Conference session, Andreasen gave a morning devotional talk, using as his key text Rev 14:12: "Here is the patience of the saints: here are they that keep the commandments of God, and the faith of Jesus." Zeroing in on the phrase, "Here is the patience of the saints," Andreasen notes that the word patience occurs five times in Jas 5:7-11 in the context of waiting for the second coming of Christ. He then turns to the experience of Job, whose story Andreasen believes was "written for a specific purpose," which turns out to be to enlighten and encourage the last generation. ${ }^{82}$

Andreasen highlights the elements of challenge, demonstration, and vindication that are present in the story of Job's experience. Satan challenged God that if He would take away all that Job had, Job would curse Him. The challenge was that "Job served God because it was paying him; that God had put a hedge about him; that Satan could not get at him." God accepted the challenge, confident that Job would endure the test, and Job's faithfulness under trial vindicated God of the charges of Satan. Andreasen stresses

${ }^{81}$ Andreasen, "The Christian Life," 24-25. Lesson 10 is entitled "Patience."

${ }^{82}$ M. L. Andreasen, "Morning Devotional Study: Patience of the Saints; Commandments of God; the Faith of Jesus," Thursday, June 3, 8:45 A.M., General Conference session, Advent Review and Sabbath Herald, June 9, 1926, 23-24. 
that Job "did not know what was going on in heaven. He did not know of the challenge, and that he was being put to the test, and that the Lord was depending upon him." Yet "God's confidence in him was not misplaced." ${ }^{\prime 3}$ In his 1937 The Sanctuary Service Andreasen again emphasizes that Job knew nothing of the challenge of Satan and that "God is depending upon him in the crisis through which he is passing." Job rather argues his innocence; even "God Himself says it [Job's trial] was without cause."

The whole experiment can therefore be justified only by considering it as a specific test devised for a specific purpose. God wanted to silence Satan's charge that Job served God only for profit. He wanted to demonstrate that there was at least one man whom Satan could not control. Job suffered as a result of it, but there seemed to be no other way. ${ }^{84}$

Andreasen here clearly emphasizes God's depending on Job's fidelity as a demonstration of obedience without regard for personal profit, in order to refute Satan's challenge. Job's suffering is seen as necessary for God's acquittal.

Andreasen further develops the idea that God depends on human witnesses in connection with his interpretation of the experience of the last generation. In answer to the question of how God should deal with Satan's charges, Andreasen likens the situation to that of a case tried at court: "The only way the matter could be satisfactorily settled so that no question would ever arise again, was for God to submit His case to the ordinary rules of evidence.... There was no other way than for each side to present its evidence, produce its witnesses, and rest its case on the weight of testimony adduced.. ${ }^{95}$ The motifs

${ }^{83}$ Ibid., 24.

${ }^{84}$ Andreasen, The Sanctuary Service, 314.

${ }^{85}$ Ibid., 315. In his Sabbath School lesson helps for the fourth quarter of 1928 (the second in a series of three on the book of Isaiah), Andreasen had highlighted what he 
of challenge and dependence in connection with the last generation are already very clear in Andreasen's 1926 devotional on the patience of the saints. Without the knowledge of Job's experience, God's witnesses might become confused, but when they remember Job's experience the end-time saints realize that "there is something going on in heaven, that there is a challenge, that there is a test, and that God is depending upon [them] to do right. ${ }^{\circledR 86}$ Near the end of his chapter on the last generation, Andreasen makes an appeal to his readers: "The issue is before us and will be decided in the lives of God's people. God is depending upon us as He did upon Job. Is His confidence well placed?" ${ }^{87}$ Again is seen the element of risk that Andreasen accepts, even to the point of framing this question regarding God's confidence in the last generation, implying the possibility that God might be embarrassed by the failure of His people.

Andreasen also points out the similarities between the severe trial of the end-time saints compared to that of Job. Just as in Job's case, the last generation "will have every earthly stay removed; Satan will be given permission to torment them. In addition to this the Spirit of God will be withdrawn from the earth, and the protection of earthly governments removed. God's people will be left alone to battle with the powers of

considered to be "one of [Isaiah's] fundamental teachings, namely, that God's people are His witnesses. The significance of this should not escape us. Witnesses are used or summoned in a trial... The nations are challenged to bring their witnesses, and God will bring His. On the testimony of these witnesses hangs the case." Here, though, the contested issue (following Isaiah) is not whether any sincerely obey God, but "Who is the true God?'” M. L. Andreasen, Isaiah, the Gospel Prophet, a Preacher of Righteousness, 3 vols. (Washington, DC: Review and Herald, 1928), 2:29.

\footnotetext{
${ }^{86}$ Andreasen, "Patience of the Saints," 25.

${ }^{87}$ Andreasen, The Sanctuary Service, 320.
} 
darkness. They will be perplexed, as was Job." ${ }^{18}$ Just as Job "searched his soul, and he did not know of any specific wrong he had done," ${ }^{89}$ so the end-time saints will "search their souls to see if any sin is left," but "there is "nothing' against them." ${ }^{90}$ And just as in Job's case, the "only limitation" on Satan, apparently, is that "he may not kill God's people." "Satan will have a greater measure of control than he has ever had before." ${ }^{91}$ But even though they "seemingly ... must fight their battles alone," without an intercessor in the sanctuary in heaven, God "provides them with food, shields them from destruction, and supplies grace and power for holy living. ${ }^{, 92}$ Andreasen, then, does not maintain that the saints are left totally alone, but recognizes that they continue to be sustained by God's power during their time of testing.

\section{Demonstration of the Gospel's Power}

The notion of demonstration is prominent in the writings of Andreasen, especially in relation to eschatology. Just as Andreasen takes Rev 14:12 as a foundation for relating the experiences of Job and the last generation, he similarly uses this text as the biblical basis for understanding the end-time saints as a culminating demonstration of the power of the gospel. Writing in 1939 on Rev 14:12, Andreasen points out:

The wording of the text answers the question in the minds of some in regard to whether it is really possible to keep the law of God.... One can almost hear the

\footnotetext{
${ }^{88}$ Ibid., 314-315.

${ }^{89}$ Andreasen, "Patience of the Saints," 24.

${ }^{90}$ Ibid., 25.

${ }^{91}$ Andreasen, The Sanctuary Service, 317.

${ }^{92}$ Ibid., 318.
} 
challenging objections: It is impossible to keep the law of God. Show me a man who has ever done it or who can do it. You claim that it can be done. Where are they who do it? The answer comes ringing back: Here they are. "Here are they that keep the commandments of God, and the faith of Jesus." 93

Though "each generation" needs a demonstration of "what God is like," such as Christ gave in His life, ${ }^{94}$ Andreasen conceives of a particular demonstration to be given at the end of time. This "final demonstration" of the power of God and the power of Satan Andreasen sees as critical to the conclusion of the cosmic conflict: "Both God and Satan should present their finished product, that men may see and judge of the relative merits of the two antagonists. Only such a demonstration will satisfy the onlooking universe." ${ }^{95}$ Andreasen contends that a demonstration of the power of Christianity to "change lives and dispositions" "has never been given to the world on any adequate scale." " By "any adequate scale" Andreasen does not mean geographical extent, but the extent to which Christians have overcome sin. He contends that the "finished product" of God's power is complete sanctification, a restoration of the image of God. "It is for this demonstration of what the gospel can do for a man that the world is looking." Andreasen is even willing to reduce the needed demonstration to just one person: "It is necessary for God to produce at least one man who has kept the law. In the absence of such a man, God loses and Satan wins." 97

\footnotetext{
${ }^{93}$ Andreasen, The Faith of Jesus and the Commandments of God, 549.

${ }^{94}$ Ibid., 183.

${ }^{95}$ Ibid., 563.

${ }^{96}$ Ibid., 11.

${ }^{97}$ Andreasen, The Sanctuary Service, 301, 316. Emphasis original.
} 
This demonstration of the power of the gospel is linked by Andreasen with the end-time sealing. "Christ places His seal" on one who has overcome all temptations, and stands without fault before God's throne. "God has finished His work in him. The demonstration of what God can do with humanity is complete." "All who bear God's name, who have it written in their foreheads, have ceased from sin. They are holy, they are without fault even before the throne of God." ${ }^{98}$ This conviction that the end-time saints will give a demonstration of complete victory is also seen in Andreasen's Sabbath School helps for 1929: "God intends to exhibit His people to the world. He wants to demonstrate what can be done in human flesh; and He will not rest satisfied until His people reflect His image fully." ${ }^{\prime 9}$

Though Andreasen declares that God needs to produce at least one person who keeps the law in order to prove His case,${ }^{100}$ in his "Last Generation" chapter he emphasizes the completeness and extent of the actual demonstration. "God will produce not only one or two who keep His commandments, but a whole group, spoken of as the 144,000."101 Further, the "chosen ones" selected for meeting Satan's challenge are not outstanding specimens of humanity. "Not the strong or the mighty, not the honored or the rich, not the wise or the learned, but common, ordinary people will God take, and through and by them make His demonstration." ${ }^{102}$ Andreasen points repeatedly to the weakness of

\footnotetext{
${ }^{98}$ Ibid., 302; Andreasen, The Sabbath: Which Day and Why? 249.

${ }^{99}$ Andreasen, Isaiah, the Gospel Prophet, a Preacher of Righteousness, 3:65.

${ }^{100}$ Andreasen, The Sanctuary Service, 316.

${ }^{101}$ Ibid., 315.

${ }^{102}$ Ibid., 316-317.
} 
the last generation as qualifying them to be a demonstration of God's power. "He will take the weakest of the weak, those bearing the sins of their forefathers, and in them show the power of God. . . . They will demonstrate that it is possible to live without $\sin .{ }^{\prime 103}$

Andreasen makes an important observation that seems to contradict the idea that

God needs to show only one person who keeps the law:

When God commands men to keep His law, it does not serve the purpose He has in mind to have only a few men keep it, just enough to show it can be done. It is not in line with God's character to pick outstanding men of strong purpose and superb training, and demonstrate through them what He can do. It is much more in harmony with His plan to make His requirements such that even the weakest need not fail, so that none can ever say that God demands that which can be done by only a few. ${ }^{104}$

This demonstration is quite different from the one Andreasen identifies on page 316, in which at least one obedient person would win the day for God. Not only does this sizable group bear the "results of accumulated sins" and "suffer from inherited tendencies"; "God intends in His demonstration to show, not merely that ordinary men of the last generation can successfully pass a test such as He gave to Adam and Eve, but that they can survive a test much harder than such as falls to the lot of common men." Andreasen concludes that the test will be "approaching that which the Master underwent."105 The portrayal of the last-day demonstration concludes with God hiding Himself from His people: “God, to make the demonstration complete, does one more thing. He hides Himself. The sanctuary in heaven is closed. The saints cry to God day and night for deliverance, but He appears not to hear." In experiencing the hiding of God, the last generation are seen

\footnotetext{
${ }^{103}$ Ibid., 302.

${ }^{104}$ Ibid., 312.

${ }^{105}$ Ibid.
} 
to share to some extent the depth of Christ's suffering. They pass with Him "through Gethsemane. They are having a little taste of Christ's experience those three hours on the cross." $" 106$ In his 1926 portrayal of the Job-like trial of the last generation, Andreasen pictures a scene very similar to that of Christ in Gethsemane: "When the people of God pass through that experience, the angels of God are anxious to come to their help; but the commanding angel says, 'Not yet. They must drink of the cup." "107 Such is the completeness of the demonstration God is said to make in the last generation.

Andreasen paints in bold colors the impact of this final exhibit on the cosmic controversy. Except for "Christ's godly life on earth and His supreme sacrifice on Calvary," Andreasen sees this as "the most sweeping and conclusive demonstration of all the ages of what God can do in men." 108 For Andreasen, the last generation's experience proves that it is certainly possible for humans to obey God's laws: "In the last generation God gives the final demonstration that men can keep the law of God and that they can live without sinning." The last generation's experience effectually closes the mouths of the whole human race. "God demonstrates through the weakest of the weak that there is no excuse, and never has been any, for sinning. If men in the last generation can successfully repel Satan's attack; if they can do this with all the odds against them and the sanctuary closed, what excuse is there for men's ever sinning?"109 Besides showing the

${ }^{106}$ Ibid., 317-318.

${ }^{107}$ Andreasen, "Patience of the Saints," 25. Cf. E. G. White, Desire of Ages, 693; idem, Great Controversy, 630-631.

${ }^{108}$ Andreasen, The Sanctuary Service, 303.

${ }^{109}$ Ibid., 318. 
emptiness of excusing one's sin on account of weakness, Andreasen points out that the trial of the last generation proves that their obedience is not conditioned by the anticipated reward. They are serving God "from motives of loyalty and right without reference to reward." "They are willing to die rather than to sin."110

\section{Vindication of God}

Of course the most critical result of the demonstration made in the last generation is the vindication of God in the controversy between good and evil. As Haynes pointed out, the motif of God's vindication is at the heart of Andreasen's last-generation theology. ${ }^{111}$ Andreasen views God, having been accused of injustice, as setting "Himself the task of justifying His ways before men."112 The issue at stake is not the salvation of repentant humans, but the refutation of Satan's challenge:

The matter of greatest importance in the universe is not the salvation of men, important as that may seem. The most important thing is the clearing of God's name from the false accusations made by Satan. The controversy is drawing to a close. God is preparing His people for the last great conflict. Satan is also getting ready. The issue is before us and will be decided in the lives of God's people. ${ }^{113}$

Andreasen is clear that it is through the last generation of saints that God's name is finally cleared, and not before. Repeatedly in his chapter on the last generation, he proclaims that "it is in the last generation of men living on the earth that God's power unto sanctification will stand fully revealed. The demonstration of that power is God's

${ }^{110}$ Ibid., 317.

${ }^{111}$ Haynes, “The Final Generation,” 69 n. 2.

${ }^{112}$ Andreasen, The Faith of Jesus and the Commandments of God, 302.

${ }^{113}$ Andreasen, The Sanctuary Service, 320. 
vindication. It clears Him of any and all charges which Satan has placed against Him. In the last generation God is vindicated and Satan defeated." 114 Through the last generation God "defeats Satan and wins His case. They form a vital part of the plan of God." 115 It is clear that, in Andreasen's understanding, God's character is not clear of all suspicion until it is shown that His law is not severe, and that He is not "unjust in demanding that men keep the law." ${ }^{116}$ In Andreasen's reckoning, then, the task of the last generation is crucial to the outcome of the great controversy and the plan of salvation.

\section{Salvation as Complete Victory over Sin}

It should be clear after reviewing the elements of challenge, evidence, and vindication in Andreasen's final-generation theology, that the overcoming of sin is a critical end-result of the plan of salvation. Andreasen links the complete victory of the end-time saints with the Adventist doctrine of the cleansing of the heavenly sanctuary shortly before the second Advent. In addition to an examination of the way lastgeneration theology involves the sanctuary doctrine, this section will take a closer look at Andreasen's understanding of sin, obedience, and salvation.

\section{Purpose of the Sanctuary}

Whether Andreasen's views on end-time perfection influence his understanding of the meaning of the Old Testament sanctuary service, or vice versa, there is a strong

${ }^{114}$ Ibid., 303-304. Cf. "In the last generation God will stand vindicated. In the remnant Satan will meet his defeat." Ibid., 315.

${ }^{115}$ Ibid., 319.

${ }^{116}$ Andreasen, The Sabbath: Which Day and Why? 312. 
relationship between the two. He is quick to point out the repeated calls of the Old Testament prophets for correction of priestly corruption. At the 1936 General Conference session Andreasen addressed the delegates on the subject of "The Keeping Power of God." The thrust of the message is that Christians need to look to the power of God to keep them from falling, rather than primarily depending on the forgiving power of God in relation to sin. Andreasen contends that "all the way through the Old Testament" God's message through the prophets, directed "especially to His priests," was “"Behold, to obey is better than sacrifice [1 Sam 15:22]." ${ }^{\prime 17}$ The idea is that rather than relying on the priestly sacrifices as the way to please God, it would be much better to obey and thus obviate the need for the sacrificial system. To this goal of salvation history Andreasen believed the sanctuary service pointed. In his 1939 The Faith of Jesus, Andreasen made the same point - that the end of sin would be the end of sacrifice and intercession. Commenting on the scribe who asked Jesus about which was the greatest commandment, Andreasen noted that the scribe realized that there would be no sin offerings if transgression ceased: "If it were possible to keep the law, no more sin offerings were needed." 118

Much significance is seen by Andreasen in the differences between the daily services in the Holy Place and the yearly service in the Most Holy Place of the sanctuary. Sins were forgiven in the daily service, but not blotted out until the yearly Day of Atonement. In his 1936 General Conference study, Andreasen is clear regarding what is

\footnotetext{
${ }^{117}$ M. L. Andreasen, "Morning Bible Study: The Keeping Power of God," Advent Review and Sabbath Herald, June 18, 1936, 298.

${ }^{118}$ Andreasen, The Faith of Jesus and the Commandments of God, 45.
} 
to be understood by the blotting out of sin: "God wants us to pass from the first to the second apartment, the first standing for forgiveness, the second for the blotting out of sins. Wonderful as is the doctrine of forgiveness, there is a still higher power, that of keeping from sinning." "As he explains in his chapter on the priesthood in The

\section{Sanctuary Service:}

Forgiveness operates ... when the damage already has been done. True, God forgives the sin, but it would have been better had the sin not been committed. For this the keeping power of God is available. To forgive the transgression after it has been committed is wonderful; but it is not enough. There must be a power to keep from sinning. ${ }^{120}$

Andreasen goes on to point out that those who "enter with Christ into the most holy" will be without spot or wrinkle, enjoying the fullness of the gospel. In his study on "The Keeping Power of God" Andreasen links the experience of following Christ into the Most Holy Place of the heavenly sanctuary, where sins are blotted out, with Dan 9:24: “Are we ready to follow the direction given here to go with Him into the most holy, where sins are blotted out, where there is an end of sin, where transgression is finished, where reconciliation for iniquity — that means making right, restoring, clearing up the King's highway, and then bringing in everlasting righteousness — is made?"121 A subtle, but interesting insight into Andreasen's understanding of righteousness by faith is seen when he links the first-apartment ministry of forgiveness with righteousness by faith, and the second-apartment ministry with sanctification in the next, closing paragraph: "Are we

${ }^{119}$ Andreasen, “Keeping Power of God,” 299.

${ }^{120}$ Andreasen, The Sanctuary Service, 49.

${ }^{121}$ Andreasen, "Keeping Power of God," 299. 
willing to accept the forgiving power of God? We need that, friends, but we also need the keeping power of God. We need righteousness by faith, but also, friends, we need the right kind of sanctification.” From this, it seems Andreasen may have understood righteousness by faith as justification by faith, and so felt the need to urge his hearers on to sanctification. What is clear is that Andreasen considered it to be moving in the wrong direction to trust in the forgiving power of God "to the exclusion of the higher power, that of abstinence from sin, or being kept from sin., ${ }^{122}$

It is not difficult to determine Andreasen's interpretation of the antitypical Day of Atonement. In the concluding paragraph of "The Last Generation" chapter, Andreasen asserts that the "cleansing of the sanctuary in heaven is dependent upon the cleansing of God's people on earth." Along with the need for confession of every sin, he also says that "no stain of evil remains," and that "every sin must be burned out" in God's people so that the fire of God's presence does not consume them. ${ }^{123}$ He also points out the need for complete eradication of $\sin$ from the redeemed, for the purpose of the eternal security of the universe. ${ }^{124}$ Finally, in his commentary on Hebrews, he plainly states that "part of the cleansing of the true sanctuary" includes "eliminating and destroying sin in His saints on earth." ${ }^{125}$

${ }^{122}$ Ibid.

${ }^{123}$ Andreasen, The Sanctuary Service, 321.

${ }^{124}$ Andreasen, The Faith of Jesus and the Commandments of God, 123.

${ }^{125}$ Andreasen, The Book of Hebrews, 60. 


\section{Views of Sin and Obedience}

Because Andreasen strongly advocates the entire overcoming of sin on the part of the last generation, it is important to understand his view of the law and sin. It may be significant that even in his chapter on the last generation Andreasen defends a high view of the law, taking issue with those who "flaunt their sanctity before men and would have us believe that they are without sin." These "have no just conception either of sin or of God's holiness, whose spiritual vision is so impaired that they cannot see their own shortcomings, and hence believe themselves perfect."126 Against those who "glibly" say the law can be kept, Andreasen cautions:

God's law is exceedingly broad; it takes cognizance of the thoughts and intents of the heart. It judges motives as well as acts, thoughts as well as words. Commandment keeping means entire sanctification, a holy life, unswerving allegiance to right, entire separation from sin, and victory over it. Well may mortal man cry out, Who is sufficient for these things! ${ }^{127}$

Therefore it seems that Andreasen's vision of a final generation that perfectly overcomes sin must not be based on a low view of the law, that only involves outward acts. This should be kept in mind when one considers what Andreasen says a page or two earlier regarding the justice of God in demanding obedience to the law: "It is much more in harmony with His plan to make His requirements such that even the weakest need not fail." ${ }^{28}$ An apparent contradiction between a high view of the law and "requirements" that do not present an impossibility even for the "weakest" can be resolved by

${ }^{126}$ Andreasen, The Sanctuary Service, 299.

${ }^{127}$ Ibid., 310.

${ }^{128} \mathrm{Ibid} .$, 311-312. Andreasen also presents as evidence for God's fairness, His creating such a simple test for Adam and Eve. 
understanding these "requirements" to assume, and provide for, the cooperation of divine and human power.

Andreasen views sin as much more than outward acts, but rather as a condition. In his chapter on the last generation he states that sin leaves a person in "a deplorable condition—weak despondent, disheartened. He has little control of his mind, his will fails him, and with the best of intentions he is unable to do what he knows to be right." 129 In his 1939 The Faith of Jesus Andreasen faults the Pharisees for their focus on outward form, concluding that "it had apparently not dawned on them that sin is more than act, that $\sin$ is a state of mind, an attitude, as well as an outward act." ${ }^{130}$

It is actually inherent in Andreasen's theology that the process of overcoming sin be more than simply eliminating unlawful behaviors. To simply stop sinning for a time would not be the evidence that is needed. "It is not enough to be innocent. Adam was innocent." Thus Andreasen argues that a "test" or "trial" was necessary, and is now necessary again to prove that humans would "die rather than sin.",131

Andreasen often stressed a pair of qualities that he held to be essential for salvation-love of righteousness, and hatred for sin. In Andreasen's estimation, sin is not overcome until one hates it. In the first chapter of The Sanctuary Service, Andreasen emphasized the important role that hatred for sin plays in the process of salvation: "Hatred of sin is vital to full salvation. Humanly speaking, no man is safe until he has

${ }^{129}$ Ibid., 300.

${ }^{130}$ Andreasen, The Faith of Jesus and the Commandments of God, 439.

${ }^{131}$ Ibid., 134. 
learned to hate sin as deeply as he formerly loved it. He may resist sin. He may even flee from it, but as long as there is a lingering love of sin in the heart, he is not on safe ground." Andreasen saw hatred for sin to be "a great factor in our struggle with evil and our eventual victory over it." ${ }^{\prime 132}$ From this it is clear that Andreasen understood the last generation as demonstrating a changed heart, and not just outwardly correct behavior. As he puts it in his 1939 The Faith of Jesus, "Christianity is more than getting rid of certain undesirable traits. It includes the acquisition of the opposite characteristics.... Such a demonstration the church owes the world." ${ }^{, 133}$

\section{Salvation as Complete Restoration}

Andreasen understood the essence of salvation to be a restoration of the human condition before the Fall. He was clear that the means of salvation was provided at the cross. He stressed that it is "the power in the blood" that cleanses and makes atonement. No one is saved "by law," "by good works," or "by conforming to rules."134 Andreasen rejected any moral influence theory of the atonement. He "dismiss[ed] any theory of atonement which makes Christ's example the sole factor in our salvation. Example has

${ }^{132}$ Andreasen, The Sanctuary Service, 15. Haynes considers hatred of sin to be one of the "axioms" of Andreasen's last-generation theology, noting its occurrence in nearly every chapter of The Sanctuary Service. Haynes, "The Final Generation," 71 n. 2.

${ }^{133}$ Andreasen, The Faith of Jesus and the Commandments of God, 135.

${ }^{134}$ Andreasen, The Sanctuary Service, 94-95. 
its place; it is vital indeed, but the death of Christ remains the central fact in the

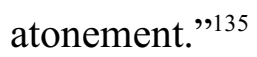

However, Andreasen understood Christ's mission as much more than to make forgiveness possible. He posits that Christ makes an end of the sacrificial system not so much by offering the great, antitypical sacrifice as by doing away with sin, which would make the sacrifices pointless. When Jesus spoke to the scribe about the first commandment in the law, the scribe replied that to love God and neighbor was "more than all whole burnt offerings and sacrifices" (Mark 12:33). Andreasen pictures the scribe and those with him mulling things over: "If they accepted Jesus as their sacrifice, they might as well close the temple. Moreover, they also realize that the temple of which they were so proud, had its existence only because of sin. What would happen if they should accept the teachings of Jesus and go and sin no more?"136 Andreasen saw the goal of the Old Testament temple rites, and the mission of Christ, to be the elimination of sin in the worshipers. Each sacrifice was to teach an "abhorrence for sin." 137

Andreasen outlines his understanding of the process of salvation near the beginning of his "Last Generation" chapter. He sees two components: (1) forgiveness, which is "conditioned upon breaking with" sin; and (2) sanctification, or "complete restoration," which "indicates deliverance from its power and victory over it. The first is a means to neutralize the effect of sin; the second is a restoration of power for complete

\footnotetext{
${ }^{135}$ Andreasen, The Sanctuary Service, 93 (1937 ed.). This is in the original edition only.

${ }^{136}$ Andreasen, The Faith of Jesus and the Commandments of God, 46.

${ }^{137}$ Andreasen, "Keeping Power of God," 298.
} 
victory." 138 Here he uses the illustration of the ship "towed" to port; it is "safe but not sound." So the person who is forgiven is salvaged, but needs repairs. When this is finished the person is "completely sanctified, and restored to the image of God."139 Andreasen points out that it is this end product that has yet to be produced in salvation history.

In A Faith to Live By, published in 1943, Andreasen asserts that humans "must be restored through the wonderful power of forgiveness to the estate which Adam had before his fall, and then the power of God must be applied to keep [them] from falling again. [They] must be tested as was Adam, and [they] must stand the test." ${ }^{140}$ If Andreasen's words are taken at face value, it seems he understood forgiveness to include the impartation of a new nature that rather cancels out the old, fallen nature. But this may be reading him too literally. It is clear, though, that Andreasen believed that God had "made possible the nullifying of the effects of sin for such as serve Him, and that abundant provision has been made in the gospel for complete deliverance from inherited and cultivated tendencies." $" 141$ The fallen nature certainly could not be used as an excuse for sin, in Andreasen's understanding.

Of course, Andreasen did not normally use terms such as "fallen nature" or "sinful nature," as the battle regarding the nature of Christ's humanity had not yet commenced in

\footnotetext{
${ }^{138}$ Andreasen, The Sanctuary Service, 300.

${ }^{139}$ Ibid., 301.

${ }^{140}$ Andreasen, A Faith to Live By, 53.

${ }^{141}$ Andreasen, The Faith of Jesus and the Commandments of God, 252.
} 
the Adventist church. But there is an interesting statement in the original edition of The Sanctuary Service that may shed a bit of light on his thinking. In explaining the ways in which sins were transferred to the sanctuary, Andreasen states that when the priest ate the animal over which sins had been confessed, he "took upon himself sinful flesh, and thus carried the "iniquity of the congregation."'142 This is expanded in its application to Christ in the 1947 edition, but without the use of the term "sinful flesh": "As the last part of the ceremony the priest has eaten the flesh of the sin offering in the court of the tabernacle, by this act taking the sin upon himself, bearing 'the iniquity of the congregation.' ... In doing this the priest is symbolic of Him who 'bare the sin of many,' upon whom the Lord laid "the iniquity of us all.",143 The change in wording from "sinful flesh" to "sin" may not be significant; however, Andreasen's comparison of the tasks of Christ and of the last generation seems to imply an identical human nature, though not explicitly: "The final demonstration of what the gospel can do in and for humanity is still in the future. Christ showed the way. He took a human body, and in that body demonstrated the power of God. Men are to follow His example and prove that what God did in Christ, He can do in every human being who submits to Him." ${ }^{144}$ It is not necessary to understand Andreasen to imply here that Christ took fallen human nature. However, it is clear that Andreasen understood that Christ will replicate in the end-time saints the victorious life He lived while on earth. Only in this way would the plan of salvation, which for Andreasen

\footnotetext{
${ }^{142}$ Andreasen, The Sanctuary Service, 1937 ed., 135-136.

${ }^{143}$ Andreasen, The Sanctuary Service, 137.

${ }^{144}$ Ibid., 299.
} 
anticipates the restoration of the image of God, be finally complete.

\section{Summary and Conclusion}

M. L. Andreasen's understanding of the significance of the earth's final generation in relation to the cosmic controversy between good and evil builds on the foundation laid by previous generations of Adventist adherents. He rose to influence at a time of emphasis upon victorious Christian living and righteousness by faith, as well as a time of disturbing defections over the church's sanctuary doctrine.

A. G. Daniells, church president until 1922, and then foremost in giving birth to the new Ministerial Association, urged a greater focus on Christ and righteousness by faith, while giving proportionally less prominence to unique Adventist teachings such as the sanctuary. He expressed an urgently felt need for church members to prepare for translation by feeding on Christ-centered preaching and literature.

W. W. Prescott was a General Conference field secretary at the time of Andreasen's rise. A reading of his sermons makes it clear that he believed that humans could overcome as Christ did, and that this was a necessary preparation for translation. In a series of evangelistic sermons during the 1890s, he referred to Job in the context of the cosmic controversy, as a demonstration before the onlooking universe of a person who could be trusted to show the power of God's love to hold one fast in time of trial. At the same time, he pointed to Christ's mission on earth, which vindicated God before the universe and sealed the fate of Satan.

Meade MacGuire worked with A. G. Daniells in the new organization for ministers, publishing books on victorious Christian living. His 1930 General Conference 
address on the cleansing of the sanctuary exhorted delegates to stop the flow of sins going into the heavenly sanctuary, so that Christ could end His work of intercession and return to earth triumphant.

At the same time, disturbing questions were being raised regarding the Adventist sanctuary, which led to the defections of L. R. Conradi and W. W. Fletcher, leaders in Europe and Australia, respectively. In response, top Adventist administrators published books and articles defending the Adventist sanctuary doctrine. Church president C. H. Watson argued for a final atonement in the heavenly sanctuary, but as the condition for having sins blotted out, emphasized confession of sin and a clear conscience, rather than perfect behavior. Vice-president W. H. Branson stressed the need for allowing Christ to live His life of perfect obedience in human flesh. It was seen that although writers touched upon issues of theodicy in dealing with the sanctuary doctrine, this was often done by way of answering the charges of critics, and not as a clear expression of the relationship between the sanctuary teaching and the great controversy motif.

M. L. Andreasen was positioned by circumstances to be a link between Adventist leaders at the end of the nineteenth century and the new generation that came on the scene during the 1920s to the 1940s. Converted to Adventism as an independent youth, Andreasen's questioning mind was exposed to the thinking of leaders in the debate over righteousness by faith. At the same time he became familiar with the questions of defectors such as Ballenger, Conradi, and, no doubt, Fletcher. He was among the first Adventists to acquire a graduate academic degree, and promoted academic scholarship and institutional accreditation. His personal contact with Ellen White and time spent in her office increased his appreciation of the value of her messages. 
Andreasen published his views on the last generation beginning in 1926, but it was not until 1937, when he became a professor in the new, permanent theological seminary, that he wrote out his views completely, in the penultimate chapter of The Sanctuary Service, entitled, "The Last Generation.”

In Andreasen's view, Satan's charges against God were not completely silenced by the cross. Satan believed he could still defeat God if he could prevent God's people from obtaining a complete victory over sin. Job is identified as one upon whom God depended to demonstrate the loyalty of one of his followers, regardless of personal gain or loss. This test showed that Job obeyed out of love for God, not because of blessings received. Andreasen argues that this dependence of God on a human witness is a type of what will transpire during the time of trouble after the intercession of Christ ends. God will depend on the last generation of believers to hold fast their faith despite being apparently abandoned, as Christ experienced in Gethsemane and on the cross. They will demonstrate complete victory over sin, choosing rather to die than sin. This will vindicate God of the charge that He is unfair in demanding obedience, since the last generation proves that the law is not impossible to obey. The last generation is the weakest generation in history, while these individuals undergo the severest test, so that their perfect obedience leaves the entire human race without excuse for their sin. According to Andreasen, this final demonstration of the power of the gospel is part of God's plan for dealing with the challenges of Satan.

Important to Andreasen's view is his understanding of sin and salvation. Sin consists not merely of external behaviors, but is a deep-seated attitude. Therefore, it will not do for God to produce a generation of law keepers, merely; until a group of people 
comes to the point that they would rather die than sin, who manifest the fullness of a divinely implanted hatred for sin, His objective is not met. The last generation of believers experiences a victory over sin similar to that of Jesus. This is integral to the meaning of the cleansing of God's people in conjunction with the cleansing of the heavenly sanctuary.

The picture that Andreasen paints of the last generation is very clear. Their mission is defined precisely. The question that remains to be answered is whether this picture was in basic harmony with what other Adventist leaders envisioned, or whether it diverged significantly. It could be that he made explicit what was implicit in the views of others. Or being the independent thinker that he was, he may have created a genuinely fresh approach to Adventist understandings of the sanctuary and last-day events. The task of identifying to what extent Andreasen is in harmony with Adventist writers of the nineteenth and early twentieth centuries belongs to the next chapter of this study. 


\section{CHAPTER 5}

\section{ANDREASEN'S VIEWS COMPARED WITH RELATED THEMES IN THE WRITINGS OF OTHER ADVENTIST WRITERS}

\section{Introduction}

Having examined the writings of M. L. Andreasen and other Seventh-day Adventist authors for views related to the end-time generation of believers, it will now be helpful to compare the last-generation concepts of Andreasen with those of other Adventist writers of his period and earlier. The purpose of this comparison is to attempt to determine the unique elements of Andreasen's final-generation theology, while looking also for possible antecedents to these views. Thus both similar and contrasting elements were of interest in this comparative study. It should be emphasized that in perusing the writings of Ellen White and other Adventists, the object of this study was to discover correlations with Andreasen's thought, not to describe and analyze these other writers' ideas separately. That is, contrasting elements were uncovered as a by-product of this search for similarities, and not as the result of a thorough study of the ideas of these other writers (except that the writings of Ellen White are given much more attention, with much more breadth of coverage).

The first part of this comparison focuses on the concept of complete victory over sin by the final generation. Pertinent statements of Ellen White, first, and then other 
Adventist authors are analyzed for similarities and differences with regard to Andreasen's views on the extent of the overcoming to be realized by the final generation. This is followed by a second section that in a similar manner compares the writings of Andreasen and other Adventist writers on the significance of this overcoming on the part of the final generation. Elements of challenge and vindication of the divine law and government are thus the focus of attention in this second section. ${ }^{1}$

\section{Complete Victory over Sin}

As seen in chapter 4, M. L. Andreasen emphasized the correlation between the sanctuary service and the complete overcoming of $\sin$ in the lives of believers. ${ }^{2}$ The goal of all the sanctuary ritual was to rid the believer of sin, both in outward behavior and inward thought. This is seen most clearly in connection with the Day of Atonement service. Andreasen sees the elimination of sin in the last generation of saints as that to which this concluding service in the OT yearly ritual pointed forward.

Andreasen conceived of salvation as a restoration of what was lost in the Fall, and an undoing of the effects of sin. Humans would be brought back to the place where Adam was before he fell, and then tested to determine whether they would remain loyal. The end product of salvation history would be achieved when the believer is "completely

${ }^{1}$ This order of presentation is the reverse of chapter 4 . In that chapter, the purpose was to lay out the views of Andreasen, which are clearly based on an understanding of the final generation's role in vindicating God of the false accusations of Satan. In this chapter, however, the purpose is to compare Andreasen with other authors. For this, the presentation moves from the more similar concept - complete victory over sin - to that which is less clearly correlated - the role of the last generation in the vindication of the divine government.

${ }^{2}$ See pp. 224-227 above. 
sanctified, and restored to the image of God." ${ }^{\prime 3}$ In the next two subsections the ideas expressed by Andreasen on the overcoming of sin will be compared with those of Ellen White, and then with other Adventist writers of his time and before.

\section{Compared with the Writings of Ellen White}

Both Ellen White and M. L. Andreasen had much to say concerning the importance of obedience on the part of those preparing for translation. Beginning with her first visions in late 1844 and early 1845, Ellen Harmon (White) pointed to a special experience of holiness on the part of those preparing for the Advent. She draws attention, in relating her first visions, to the faces of the 144,000 that are lighted up with glory following the outpouring of the Holy Spirit. Though this was at a time when law and obedience had not yet attracted the attention of "shut-door" Adventists (she did not even see the Ten Commandments when she looked inside the ark of the covenant), the concern for spotlessness when standing face-to-face with Christ at His coming is clear. ${ }^{4}$

This sense of a need for holiness on the part of those preparing for translation was clarified and heightened in the 1850s. In 1851 White portrayed the holiness of God and the lack of awareness on the part of "some" regarding what was necessary to live through the time of trouble "without a high priest in the sanctuary." Through the following decades, White would repeatedly emphasize the necessity of overcoming every character

\footnotetext{
${ }^{3}$ Andreasen, The Sanctuary Service, 301.

${ }^{4}$ E. G. White, Early Writings, 15-16. See also pp. 30-32 above.

${ }^{5}$ Ibid., 71.
} 
defect in order to be ready to stand in the presence of a holy God. ${ }^{6}$ But in chapter 2 it was seen that this requirement was not unique to the final generation. Rather, believers throughout history have stood in the same need of complete victory over sin in order to be prepared to face a holy God. ${ }^{7}$

\section{Purpose of Perfection}

On this point there appears a not-so-subtle difference in emphasis between Andreasen and White. When Andreasen speaks of believers overcoming sin, it is in the context of an end-time demonstration of the efficacy of the plan of salvation, which in turn is related to theodical concerns. Thus he sums up the sanctuary service as a means of separating sinners from their sins rather than merely providing forgiveness. ${ }^{8}$ The purpose of character perfection for Andreasen is that God might be vindicated in the contest between good and evil. For White, the emphasis is on sinners preparing to meet a holy God. Thus, White tends to approach end-time perfection from an anthropocentric, soteriological point of view, while Andreasen takes a more theocentric, theodical approach.

But it must be stressed that these are only general tendencies in the writings that have been examined in this study, not mutually exclusive approaches. And even in the writings examined, both authors take both approaches. For instance, Andreasen echoes White's early writings when he speaks of the need to have "every $\sin .$. burned out" in

${ }^{6}$ See, for example, E. G. White, Testimonies, 1:705.

${ }^{7}$ Ibid., 2:452-453. See pp. 59-60 above.

${ }^{8}$ See pp. 224-225, 230-232 above. 
order that the sinner might not be consumed by the fire of God's presence. ${ }^{9}$ Likewise, White underscores eschatological aspects of character perfection in her development of the parable of the ripening ear of grain, in which Christ is depicted as awaiting the perfect reproduction in His people of His own character, which signals that the harvest is ripe. ${ }^{10}$

Another aspect of soteriological concern, with eschatological implications, is Andreasen's concept of the time of trouble as a test of the loyalty of the 144,000.

Andreasen points out that even if the saints cease to sin, it is not enough to ensure the security of the universe from reinfection with sin. Adam and Jesus also were sinless, but needed to be tested. Therefore, the loyalty of the end-time saints must be tested; the time of trouble shows that the believers would rather die than $\sin .{ }^{11}$ However, since this is only a small portion of the redeemed, the implication is that they stand as representatives of the saved multitudes, being the end-product of the plan of salvation.

On the other hand, the earlier statements of Ellen White in regard to the time of testing and the need for perfecting righteousness, that have been examined in this study, warn believers that unless they meet certain criteria they will be unprotected during the

\footnotetext{
${ }^{9}$ Andreasen, The Sanctuary Service, 321. See p. 227 above. It may be argued that Andreasen here only superficially resembles White's early concern for holiness, since the reason it is important for Andreasen that believers be purified of sin is that "the cleansing of the sanctuary in heaven is dependent upon the cleansing of God's people on earth. How important, then, that God's people be holy and without blame." Ibid.

${ }^{10}$ E. G. White, Christ's Object Lessons, 66-69. See p. 139-140 above.

${ }^{11}$ Andreasen, The Faith of Jesus and the Commandments of God, 134. See p. 229 above.
} 
time of trouble. ${ }^{12}$ In later writings, White stresses the need for character perfection so that believers might be sealed. The process of polishing goes on until a perfect image is obtained. Then the believers are sealed permanently and are able to stand during the time of trouble, almost as though there were no longer any further concern regarding the possibility of falling. ${ }^{13}$ Thus, concern is placed by White, at least in her early statements, on meeting certain criteria in order that protection may be realized during the time of trouble. Andreasen, when writing on the last generation, is also concerned that criteria are met, but not for the purpose of the saints obtaining protection. Rather he is more intent on the outcome of events during the time of trouble itself, and their implications for the controversy over God's law. This concern for God's vindication began to appear in White's writings in the 1870 s. $^{14}$

\section{Extent of Overcoming}

There is clear agreement between Andreasen and White on the attainability, as well as the extent, of perfection on the part of the last generation. Both call for overcoming every defect, whether in outward act or inward thought. Andreasen sees the gospel as encompassing "complete deliverance from inherited and cultivated

\footnotetext{
${ }^{12}$ For White's focus on this protection during the time of trouble, to be obtained by meeting certain criteria, see pp. 33-35, 37-39.

${ }^{13}$ See White's early statement, cited above on pp. 43-44, regarding the sealing placing the saints beyond the power of Satan. E. G. White, "A Vision God Gave Me," $8: 220$.

${ }^{14}$ See pp. 66-69 above.
} 
tendencies." The law "takes cognizance of the thoughts and intents of the heart." Acts, words, thoughts, and motives are all taken into account. ${ }^{16}$ Similarly, Ellen White maintains that "every evil temper, every sin, every temptation," as well as "every defect in the moral character," can be overcome. ${ }^{17}$ Just as Christ did not yield to temptation "even by a thought," "so it may be with us.","

Likewise, neither Andreasen nor White allow fallen human nature to be used as an excuse for sin. To those who argued that it was too difficult to overcome due to their fallen natures, White answered that such complaints were actually "accusations against the God of heaven." ${ }^{\prime 19}$ Rather, fallen nature is to be "purified" by obedience. ${ }^{20}$ Andreasen also argued that God "made possible the nullifying of the effects of sin" for those who desired to follow Him. ${ }^{21}$

\section{Restoration of Aspects of the Pre-Fall Human Condition}

Related to the question of the possible limitations of fallen human nature, both Andreasen and White make interesting comments on the possibilities of reclaiming or above.

${ }^{15}$ Andreasen, The Faith of Jesus and the Commandments of God, 252. See p. 232

${ }^{16}$ Andreasen, The Sanctuary Service, 310. See p. 228 above.

${ }^{17}$ E. G. White, Testimonies, 3:144, 1:705.

${ }^{18}$ E. G. White, Great Controversy, 623; idem, Desire of Ages, 123. See pp. 86, 137-138 above.

${ }^{19}$ E. G. White, “Advancing in Christian Experience,” 122. See p. 136 above.

${ }^{20}$ E. G. White, Testimonies, 5:235. See p. 64 above.

${ }^{21}$ Andreasen, The Faith of Jesus and the Commandments of God, 252. 
reforming human nature. Besides her statement that fallen nature might be purified by obedience to the truth, Ellen White also stated in the early 1880 s that obedience would "perfect Christian character, and restore man, through Christ, to his condition before the fall." ${ }^{, 22}$ Six paragraphs earlier in this article on the perpetuity of the moral law, she admits the impossibility of fallen, sinful human nature rendering obedience to the law: "After the fall, it had been impossible for man with his sinful nature to render obedience to the law of God." If the sentence ended here, it would validate the use of one's sinful nature as an excuse for sin. But White continues, "had not Christ, by the offer of his own life, purchased the right to lift up the race where they could once more work in harmony with its requirements." ${ }^{23}$ It is not altogether clear, though, whether this lifting up of the race has been universally effected, or whether Christ merely possesses the right to do this when certain conditions are met.

White continues the article with one of her clearest statements against the teaching of the impossibility of human obedience, which continues, though somewhat less directly, to speak to the question of fallen human nature and obedience:

There are persons professing to be ministers of Christ, who declare with the utmost assurance that no man ever did or ever can keep the law of God. But, according to the Scriptures, Christ "took upon himself our nature," he "was made in fashion as a man." He was man's example, man's representative, and he declares of himself, "I have kept my Father's commandments." The beloved disciple urges that every follower of Christ "ought himself also so to walk even as He walked." All who

${ }^{22}$ E. G. White, Testimonies, 5:235; idem, "The Exalted Position of the Law of God," 210 (2). See p. 64 above. Regarding what is restored, a hint is given when White states that the anguish the final generation experiences during the time of trouble "is unmistakable evidence that they are regaining the strength and nobility of character lost in consequence of sin." Idem, Testimonies, 5:474. See pp. 83 above.

${ }^{23}$ E. G. White, "The Exalted Position of the Law of God," 209 (1). 
are Christ's will follow the example of Christ. All who justify the sinner in his transgression of God's law, belong to that class of whom our Saviour said, "Whosoever therefore shall break one of these least commandments, and shall teach men so, shall be called the least in the kingdom of Heaven." They can have no part with Him who came to magnify the law and make it honorable. They are deceiving the people with their sophistry,--saying to the sinner, "It shall be well with thee," when God has declared that "the soul that sinneth ["transgresseth the law"] it shall die." ${ }^{24}$

White's article leaves some questions unanswered. In the first excerpt examined, she speaks of the impossibility of fallen human nature rendering obedience, apart from the work of Christ in lifting up the human race. When she later in the article speaks of a restoration of at least some aspect of the pre-Fall condition, it is said to be as a result of obedience itself: “Obedience to [the law's] requirements will perfect Christian character, and restore man, through Christ, to his condition before the fall.. ${ }^{, 25}$ A possible explanation of this seeming inconsistency is to understand the restoration as progressive, with two different aspects of restoration being referred to, one that enables obedience, and another that is the result of obedience. Another explanation is that in the first instance White did not understand this change of status as a restoration, even though without such an uplifting of the human race, the effects of the Fall would rule out the possibility of obedience.

Andreasen similarly refers to a restoration of aspects of the pre-Fall state. However, what is left somewhat undefined in White's statements is given more definite

${ }^{24}$ Ibid.

${ }^{25}$ Ibid., 210 (2). 
form by Andreasen. ${ }^{26}$ Andreasen argues for a neutralization of the effects of sin that is consequent upon the bestowal of forgiveness. However, this does not include complete victory over sin. In his Sanctuary Service, he states that "forgiveness" is "a means to neutralize the effect of sin," while "sanctification" "is a restoration of power for complete victory. ${ }^{27}$ Apparently, then, two stages of restoration are envisioned. In the first stage, the "effects of sin" are neutralized; in the second, "power for complete victory" is restored.

The same idea is expressed using slightly different wording in two other places. In The Faith of Jesus and the Commandments of God Andreasen speaks of God making possible "the nullifying of the effects of sin for such as serve Him,", ${ }^{28}$ showing that the restoration of this aspect of the pre-Fall condition is understood as applying not to all humans, but only to believers. This distinction is important in that it rules out a general, universal restoration, such as the capacity of free choice. In A Faith to Live By, Andreasen is also clear that the result of forgiveness is in fact a restoration of at least some aspect of the pre-Fall human condition: humans "must be restored through the wonderful power of forgiveness to the estate which Adam had before his fall."${ }^{, 29}$

\footnotetext{
${ }^{26}$ Indeed, it may be helpful to consider many of Andreasen's concepts as interpretations of White's statements, considering the extent to which he used her writings in his study and teaching. As Haynes reports, Andreasen would teach his classes using $4 \times 6$ cards of Ellen White quotes, and about $95 \%$ of his personal research material consisted of these cards. Haynes, "The Final Generation," 7.

${ }^{27}$ Andreasen, The Sanctuary Service, 300.

${ }^{28}$ Andreasen, The Faith of Jesus and the Commandments of God, 252.

${ }^{29}$ Andreasen, A Faith to Live By, 50.
} 
Thus both White and Andreasen conceive of the restoration of some aspects of the pre-Fall condition that coincide with forgiveness and/or obedience. Andreasen uses such wording explicitly in connection with both forgiveness and sanctification, while White does so in connection with obedience and character perfection. This difference may be insignificant and due simply to differences in expression of similar ideas.

\section{The Role of Christ in Showing the Way}

Both Andreasen and White lift up Christ's life on earth as proof of the possibility of human obedience and as a model for believers to follow. In 1924 Andreasen stated that Christ's life of obedience "demonstrated that it was possible for man to obey God." Again, in The Sanctuary Service, he argues that Christ, in taking "a human body" and demonstrating "the power of God," "showed the way." And when believers "follow His example" they "prove that what God did in Christ, He can do in every human being who submits to Him." ${ }^{30}$ Likewise, White asserts that Christ not only proved false the charge that "it is impossible for man to keep the law of God," but showed "that it is possible for us also to obey." ${ }^{31}$ She connects the thought of human obedience more directly with Christ's example when she points out that Christ wants to teach believers "how He overcame every temptation in humanity, and how, therefore, they may overcome through the provision the Lord has made." It is "in their fallen nature," she affirms, that believers

\footnotetext{
${ }^{30}$ Andreasen, "The Christian Life," 5-6; idem, The Sanctuary Service, 299. See pp. 210, 233 above.

${ }^{31}$ E. G. White, Testimonies, 8:207-208. See p. 135 above.
} 
are enabled to "do the very things God expects." 32 Although neither White nor Andreasen specify the exact human nature they understand Christ to have taken, the implication, in this context, is rather strong for a nature that is similar to, rather than distinct from, that of believers.

\section{Views of Sin and Righteousness}

Andreasen follows White quite closely in most aspects of his views on sin and righteousness, but shows some differences of emphasis regarding the meaning of the blotting out of sins, and the relative importance of forgiveness (justification) and sanctification. These views will be considered under three heads. First, a brief summary of shared views on law and sin will be given, followed by a discussion of differences on the meaning of the bipartite sanctuary service, including the blotting out of sin and the "keeping power" of God, and a possible variance in regard to righteousness by faith. Lastly, views related to the end-point of the process of acquiring character perfection will be compared.

Law and $\sin$

Andreasen's high view of the law has been observed. Following White, he notes that the law is "exceedingly broad," covering thoughts, intents, and motives, and not just words and acts. He has no sympathy for those who, blind to their own faults, believe

${ }^{32}$ E. G. White to Colcord, Starr, and Hickox, 53. See p. 137 above. Cf. also the connection White makes between Christ's partaking of human nature and the question of the possibility of human obedience, in the excerpt from her article, "The Exalted Position of the Law of God," 209 (1), cited on p. 245 above. 
themselves to be perfect. ${ }^{33}$ Holding this understanding of the law, it is only reasonable that Andreasen rejects a superficial view of the nature of sin. He considers sin to be "a state of mind, an attitude, as well as an outward act. ${ }^{{ }^{34}}$

Acquisition of a hatred for sin on the part of the last generation is a key component in Andreasen's eschatological perspective. As noted previously, Dwight Haynes, in his master's thesis, uses "hatred for sin" as one of his six "axioms" of Andreasen's final-generation theology, and points out that such hatred for sin occurs in nearly every chapter of Andreasen's Sanctuary Service. Andreasen sees hatred for sin as "vital" to salvation. One may "resist sin. He may even flee from it, but as long as there is a lingering love of $\sin$ in the heart, he is not on safe ground. ${ }^{335}$

White also speaks of the enmity against sin that is placed in the human heart by God, without which humans would remain captives of Satan. Love for sin is replaced by hatred for the same in the converted heart, "the converted soul has a hatred of sin," and "repentance is an intense hatred of $\sin$ in all its forms." ${ }^{36}$ However statements such as

${ }^{33}$ Andreasen, The Sanctuary Service, 299, 310. Cf. Ellen G. White, “The Character of the Law of God," Signs of the Times, April 15, 1886, 225 (1). See discussion on pp. 228-230 above. See also White's statement regarding the difficulty of humans in measuring the standard of character set before them. Idem, "Testimony to the Battle Creek Church," 70. See pp. 134-135 above. On White's denial of sinlessness, see pp. 78-79 above.

${ }^{34}$ Andreasen, The Faith of Jesus and the Commandments of God, 439. Cf. Ellen G. White, Steps to Christ (Mountain View, CA: Pacific Press, 1956), 29-30.

${ }^{35}$ Haynes, "The Final Generation," 71 n. 2; Andreasen, The Sanctuary Service, 15. See pp. 229-230 above.

${ }^{36}$ E. G. White, Great Controversy, 506, 508; idem, "Have You Oil in Your Vessels with Your Lamps?" Advent Review and Sabbath Herald, September 17, 1895, 593 (1); idem, “A Solemn Lesson," Signs of the Times, August 13, 1894, 627 (3). 
these regarding human hatred of sin, occurring in the context of repentance and conversion, do not have the same emphasis as they do when they are placed in a setting of eschatological perfection, characteristic of Andreasen's usage.

Interpretation of the sanctuary service

Andreasen's insistence on the presence of a clear hatred of sin in the final generation is based most obviously on his understanding of the meaning of the antitypical Day of Atonement and the Adventist doctrine of the cleansing of the heavenly sanctuary. Andreasen has a clear picture of this last battle in the cosmic war, one that is drawn more definitely than in White's portrayals. As seen in the discussion of his thought regarding sin and obedience, it is not sufficient to produce an end-time generation of believers that overcomes $\sin$ in the sense of merely ceasing to sin. Recapture of innocence is not what is needed; rather, a test is necessary to show that believers would rather die than $\sin .^{37}$ For Andreasen, "full salvation" and "eventual victory" occur only when this hatred of sin is demonstrated..$^{38}$

Key to understanding the differences between White and Andreasen on this point is an appreciation of their apparent different emphases in regard to the blotting out of sin on the antitypical Day of Atonement. According to White's earlier writings, the task of believers while Christ lingers in the Most Holy Place is to confess their faults and sins, so that those sins might be blotted out. At the same time, God's seal is placed upon the

\footnotetext{
${ }^{37}$ Andreasen, The Faith of Jesus and the Commandments of God, 134. See p. 229 above.

${ }^{38}$ Andreasen, The Sanctuary Service, 15.
} 
believers.$^{39}$ Writing near the same time, she mentions "a covering that God was drawing over His people to protect them in the time of trouble." 40 The concern seems to be for security during the time of trouble, to be realized by making confession of all $\sin$.

Andreasen's view of the blotting out of sin has a different focus. He declares that the cleansing of the sanctuary includes "eliminating and destroying sin in His saints.",41 Andreasen differentiates the two phases of the sanctuary service, the Holy Place ministry "standing for forgiveness," and the Most Holy Place, "for the blotting out of sins." White, in distinguishing the two apartments of the sanctuary, similarly speaks of "pardon" in connection with the "first apartment," and the "blotting out" of sins that remain on the books of record, in connection with the Most Holy Place ministry. ${ }^{42}$ And as does White, Andreasen makes the end-time cleansing of the heavenly sanctuary dependent on a thorough confession of all sin. But more than this (and here he departs rather significantly from White's focus on the removal of the record of sin from the heavenly sanctuary), Andreasen understands the blotting out of $\sin$ to be its cessation: "God wants us to pass from the first to the second apartment, the first standing for forgiveness, the second for the blotting out of sins. Wonderful as is the doctrine of forgiveness, there is a still higher power, that of keeping from sinning." $" 43$

${ }^{39}$ E. G. White, Early Writings, 48. See p. 35 above.

${ }^{40}$ Ibid., 43. See p. 36 above.

${ }^{41}$ Andreasen, The Book of Hebrews, 60. See p. 227 above.

${ }^{42}$ Andreasen, "Keeping Power of God," 299. See pp. 225-226 above. Cf. E. G. White, Great Controversy, 421-422.

${ }^{43}$ Andreasen, "Keeping Power of God," 299. See p. 226 above. Andreasen connects confession of sin with the cleansing of the sanctuary in the concluding 
Andreasen's clearly expressed view of the relationship between the blotting out of sin that occurs in the Most Holy Place of the heavenly sanctuary, and the entire eradication of sin from the lives of believers (based, in part, on his interpretation of Dan $9: 24),{ }^{44}$ seems closely related to his understanding of salvation, and also to his interpretation of the bipartite sanctuary service. As observed when discussing Andreasen's views above, near the beginning of his "Last Generation" chapter, he divides the process of salvation into forgiveness and sanctification. ${ }^{45}$ Similarly, in the concluding paragraph of his "Keeping Power" devotional talk, Andreasen, having challenged his listeners to go with Christ into the Most Holy Place, distinguishes between the "forgiving power" and the "keeping power" of God. Interestingly, he links "righteousness by faith" with this forgiving power, and "sanctification" with the keeping power. The implication is that righteousness by faith is not sufficient; rather, "the right kind of sanctification" is that of which believers "should never lose sight." ${ }^{\text {"46 }}$ In summary, Andreasen associates forgiveness and righteousness by faith with the Holy Place ministry, and sanctification and being kept free from sinning with the Most Holy Place.

The prominence that Andreasen gives to the complete overcoming of $\sin$ in connection with the cleansing of the sanctuary and the blotting out of sin, is not seen in Ellen White's writings, however. While she maintains both character perfection and

paragraph of his "Last Generation" chapter. Andreasen, The Sanctuary Service, 321. See p. 227 above.

${ }^{44}$ Andreasen, "Keeping Power of God," 299.

${ }^{45}$ Andreasen, The Sanctuary Service, 300. See pp. 231-232 above.

${ }^{46}$ Andreasen, "Keeping Power of God," 299. See pp. 225-226 above. 
confession of sins as needed elements of preparation on the part of those who are to stand during the time of trouble, in her mature writings it is the confession of sin that becomes the indispensable prerequisite. In her early writings of 1849 and 1851, both the need to make confession of one's faults and sin and to "reflect the image of Jesus fully" are clearly laid out. ${ }^{47}$ But in her fuller delineations of last-day events, a new emphasis becomes prominent. Even if White's interpretaton of Zechariah's vision of Joshua and the Angel (Zech 3) is perceived as focusing on what Adventists understand as the sealing process (occurring before the close of probation), it is still significant that at this assumedly late stage in the process of perfection, White paints a picture of saints who "may have imperfections of character" and who "may have failed in their endeavors," yet who at the same time exhibit "unfaltering faith. ${ }^{, 48}$ And as noted in the discussion of White's depiction of the time of trouble in the fourth volume of her Spirit of Prophecy (1884) and in The Great Controversy (1888), the end-time saints are depicted as experiencing self-reproach for not having always "gone forward from strength to strength," and are led to exercise faith, which has been "too little exercised during their

${ }^{47}$ E. G. White, Early Writings, 48, 71. See pp. 35, 40 above.

${ }^{48}$ Ellen G. White, The Story of Prophets and Kings: As Illustrated in the Captivity and Restoration of Israel (Mountain View, CA: Pacific Press, 1943), 588-589. These statements of White from this revised (1917) treatment of Joshua and the Angel are based on other post-1888 sources, except for the change from "earnest faith" to "unfaltering faith," which is new here. The original treatment was published in the mid-1880s. See pp. 79-83, 129-132 above. It is also interesting to note the occurrence of such terms as "transgressions," "faulty," and "unbelief," among the phrases omitted from the 1917 description of believers. Cf. idem, Testimonies, 5:474. 
religious experience. ${ }^{״ 9}$ Thus there seems to be a degree of imperfection that affects the experience of believers during the time of trouble. Indeed, it can be argued that White suggests the believers do not attain to a perfect reflection of the image of Christ even by the time of the close of probation, before which time they should have been sealed. In this same passage, describing the experience of the 144,000 during the time of trouble, White points out that the "furnace fire" is necessary for them; "their earthliness must be removed that the image of Christ may be perfectly reflected. ${ }^{, 50}$ Though this does not require that the believers be sinning after the close of probation, White's picture of the final generation seems not as unsullied as Andreasen's. White does not seem concerned with showing that the last generation has already attained to perfection, in the sense of perfect performance, but rather with their undergoing of a critical time of testing and trial, by means of which their faith and loyalty are perfected.

Furthermore, what White apparently sees as the greatest threat to their ability to endure the test is not whether they have perfectly overcome every sin, but whether these sins have been confessed and forgiven. The saints "would be overwhelmed" and "overcome by Satan" if they should be confronted with unconfessed sins. In this setting of the time of Jacob's trouble, strong warning is given, not to those who have failed to gain the mastery over every sin and wrong habit, but to those "who endeavor to excuse or conceal their sins, and permit them to remain upon the books of heaven, unconfessed and

${ }^{49}$ E. G. White, Spirit of Prophecy, 4:436-437, 446-447; idem, Great Controversy, 619, 630-631. See pp. 71-72 above.

${ }^{50}$ E. G. White, Spirit of Prophecy, 4:438; idem, Great Controversy, 621. 
unforgiven. ${ }^{.51}$ White thus stresses a preparation of deep heart-searching and confession of sins, while Andreasen emphasizes more a mature hatred of sin that is expressed in complete overcoming, as the needed preparation for the time of trouble.

One more difference should be noted in connection with the different emphases given by Andreasen and White to the bipartite sanctuary ministry. According to Andreasen's breakdown of the two phases, sanctification is the important focus of the end-time Most Holy Place ministry, which moves beyond the Holy Place ministry of forgiveness, or "righteousness by faith." ${ }^{52}$ Not only is it difficult to see in Ellen White's writings the same linking of sanctification to the blotting out of sins in the Most Holy Place ministry, but Andreasen's seeming relegation of righteousness by faith to the Holy Place ministry contrasts sharply with White's statements. In the aftermath of the 1888 General Conference session White emphatically linked justification by faith with the endtime third angel's message and its "loud cry," designed to prepare its hearers for the time of trouble. ${ }^{53}$ Furthermore, it has been shown in this study how closely White weaves

${ }^{51}$ E. G. White, Spirit of Prophecy, 4:437-438; idem, Great Controversy, 620. See pp. 70-71 above.

${ }^{52}$ Andreasen, “Keeping Power of God,” 299.

${ }^{53}$ E. G. White, “'It Is Not for You to Know the Times and the Seasons,"” 178 (2). See p. 119 above. On the link between justification and the loud cry of the third angel, see also idem, Diary entry, October 27, 1889, published under the title "Battle Creek, Mich., Sunday, October 27, 1889," The Ellen G. White 1888 Materials (Washington, DC: Ellen G. White Estate, 1987), 463; idem, "Repentance the Gift of God," Advent Review and Sabbath Herald, April 1, 1890, 193-194; idem, North Fitzroy, Victoria, Australia, to Uriah Smith, September 19, 1892, published under the title "The Message of 1888; An Appeal for Unity; The Need for the Indwelling Christ," in Manuscript Releases: From the Files of the Letters and Manuscripts Written by Ellen G. White, 21 vols. (Silver Spring, MD: Ellen G. White Estate, 1981-1993), 15:94; idem, Testimonies to Ministers and Gospel Workers: Selected from Special Testimonies to Ministers and Workers (Mountain 
together concepts of imputed and imparted righteousness, so that it is understandable how she could say that the experience of justification "is made manifest in obedience to all the commandments of God." ${ }^{54}$ White, then, does not appear to divide the sanctuary service into foci of justification and sanctification, as does Andreasen.

The end-point of the purification process

Although White cannot be seen to easily harmonize with Andreasen's interpretation of the bipartite sanctuary service, or with his linking of character perfection and the Most Holy Place ministry of blotting out of sins, there is ample evidence that she envisioned a process of overcoming sin on the part of end-time believers that would result in a perfect reflection of the image of Christ. Though perhaps Andreasen is a bit more explicit as to the progressive nature of the overcoming, with believers gaining the victory over first one sin and then another, White also depicts a process in which "the heart is tested and tried a little closer" at every point. ${ }^{55}$ In the view of both Andreasen and White, the result of this process is that believers are made ready for translation.

For Andreasen, the end-point of the gospel is reached when the believer is "completely sanctified, and restored to the image of God. It is for this demonstration of what the gospel can do for a man that the world is looking." ${ }^{16}$ White similarly regards the

View, CA: Pacific Press, 1962), 91-92.

${ }^{54}$ E. G. White, Testimonies to Ministers, 91-92. On the blending of imputed and imparted righteousness, see pp. 124-128 above.

${ }^{55}$ Andreasen, The Sanctuary Service, 302; E. G. White, Testimonies, 1:187. See pp. 55-56 above.

${ }^{56}$ Andreasen, The Sanctuary Service, 301. See p. 232 above. 
character perfection of believers as an end-time phenomenon. It is "when the character of Christ shall be perfectly reproduced in His people" that Christ will come. ${ }^{57}$ Though White's focus may be more on the production of the positive qualities of Christian character than the elimination of sinful behavior (as Andreasen tends to depict), she clearly envisions an end-time manifestation of Christ's character in believers' lives.

\section{Summary}

From this comparative view, it seems clear that Andreasen and White share much in regard to a view of the need for complete victory over sin in the final generation of believers. There is nearly complete agreement on the attainability and extent of overcoming, as well as regarding what the life of Christ proves in relation to the possibilities for overcoming on the part of believers. Both Andreasen and White suggest a restoration in believers of some aspect of the pre-Fall human condition. Andreasen sees a neutralization of the effects of $\sin$ at the point of forgiveness, with complete victory over sin delayed until the end of the sanctification process. This latter aspect seems to correlate with White's view of a restoration of the human race's "condition before the fall" through obedience. ${ }^{58}$ And there is harmony between Andreasen and White on both the progressive nature of the purification of God's end-time people, as well as the final goal of the process - a perfect reflection of the image of God.

Despite these areas of agreement, there are some significant differences between

${ }^{57}$ E. G. White, Christ's Object Lessons, 69. See pp. 138-141 above, for a discussion of White's views on the reflection of the divine image by end-time believers.

${ }^{58}$ E. G. White, "The Exalted Position of the Law of God," 210 (2). 
Andreasen and White. While both lay claim to a broad view of the nature of the law and its transgression, involving not only acts, but thoughts and motives as well, Andreasen speaks of the acquisition of hatred for sin more in connection with its end-time eradication from the hearts of believers, while White speaks of it in the context of the basic steps of repentance and conversion. A more significant area of apparent divergence is found in the meaning attached to the bipartite sanctuary service. While Andreasen divides the purpose of the Holy Place and Most Holy Place services neatly into forgiveness, or justification, and the enabling of sin-free living, or sanctification, White is not similarly prone to associate complete victory over sin with the Most Holy Place ministry of the blotting out of sin. Rather, she typically emphasizes the need for confession of all sins when speaking of the second apartment ministry. And in White's most developed writings on the post-probationary time of trouble, prior confession of $\sin$ is seen as the indispensable prerequisite for the final generation's survival. Apparently, an imperfect reflection of Christ's character poses less of a threat to the last generation than do unconfessed sins. Thus while there is strong agreement on the necessity of overcoming sin by the final generation, Andreasen and White exhibit some differences on how this relates to the sanctuary service and the blotting out of sin in the antitypical Day of Atonement.

\section{Compared with Contemporaneous and Earlier Adventist Writers}

When Andreasen's views are compared with other Adventist writers, there is more variation. The views range from those that are closer to Andreasen than is Ellen White, to those that are less compatible with Andreasen than is White. Some are very 
close to Andreasen insofar as they hold to a special work of perfecting God's people as being vital to the cleansing of the heavenly sanctuary. In this view, sins cannot be blotted out and the sanctuary cleansed while the saints are still committing sins. Other writers take a moderate position on the meaning of sins being blotted out, and even on the necessity of complete overcoming on the part of believers in order to stand during the time of trouble.

\section{An Eschatological Overcoming of Sin}

Much support can be found among other Adventist writers for Andreasen's view of a final generation that completely overcomes sin. There is broad support for complete overcoming of sin on the part of the 144,000, and considerable support for an unprecedented level of overcoming. At least one writer, though, besides Ellen White, suggests that this is not a new requirement, but simply one that is met by an entire body of believers at the same time. In $1865 \mathrm{~J}$. N. Andrews expressed the opinion that "something further than an individual work is necessary" for the final generation in order to gather them in one body and prepare them for translation. Elsewhere, he seems to indicate, similarly to White, that only "perfect overcomers" will pass the judgment, whether they are resurrected or translated. ${ }^{59}$ And although Uriah Smith reckoned the preparation required for translation to be "more difficult" than that needed to be ready to die, he also held that the position of the last generation "must be similar in many particulars" to that of previous generations. While a unique "degree of action, of

${ }^{59}$ Andrews, "Our Light and Our Responsibility," 100; idem, The Judgment, 44-45. See pp. 94-96 above. For Ellen White on the perfection required through all ages, see pp. 59-60 above. 
devotedness, and separation from the world" would be needed, "moral character must be the same in all ages." ${ }^{\circ 0}$

But other writers do seem to imply a new level of character perfection for the final generation. Much of the Adventist thinking regarding the need for this is related to the anticipated post-probationary time of trouble, in which no mediator serves in the heavenly sanctuary. As noted in chapter 2, when White's first book pointed out the holiness needed to stand in the time of trouble without a Mediator, a number of letters expressed a sense of urgent desire to meet this new standard. ${ }^{61} \mathrm{D}$. T. Bourdeau specifically points to this need to stand "without a mediator," as well as to "additional truths" that have been brought to light at the end of time, as making obligatory on the final generation a "special preparation" of complete sanctification. ${ }^{62}$ While he allows that Christ's imputed righteousness could stand for the sanctification of those who die before the work is finished in their lives, it seems clear that those living at the end of time must overcome "every sin" and reach "the pinnacle of holiness.",63

In the wake of the 1888 General Conference session, a new emphasis on perfection is seen. A. T. Jones speaks of the image of Christ perfectly reflected in the hearts of believers, which allows Him to place His seal there. ${ }^{64}$ Before Christ comes, His

${ }^{60}$ U. Smith, “[Editor's Note],” 66; U. Smith, "“If We Are Only Ready,”" 196. See pp. 99-100 above.

${ }^{61}$ See pp. 102-103 above.

${ }^{62}$ Bourdeau, Sanctification; or, Living Holiness, 104. See p. 106 above.

${ }^{63}$ Bourdeau, "Refutation of Instantaneous Sanctification," 170; idem, "Advances of God's People," 122. See pp. 106-108 above.

${ }^{64}$ Jones, “The Third Angel's Message - No. 17,” 404. See p. 152 above. 
people "must have been brought to that state of perfection in the complete image of Jesus. ${ }^{965}$ Other writers in the post-1888 era resurrected the early Adventist concern for the eradication of $\sin$ in order to be able to stand without a Mediator in the time of trouble. ${ }^{66}$ And later, at the 1899 General Conference session, delegates heard John Brunson point out the unique task that lay before them, as he called them to "get beyond" the need of mediation, to "get to a point of perfection such as the world has never yet seen," where the "work of a mediator" is no longer necessary. When "the image of Christ is perfectly reflected," the "necessity for mediation" will cease. ${ }^{67}$

This view of the complete overcoming of sin by the final generation seems to have been the prevailing position of Adventists throughout the period leading up to Andreasen's time. Beginning with the framer of Adventist theology, Joseph Bates, the call for complete eradication of sin from the lives of those preparing for translation was heard. For Bates, as later for A. T. Jones, the seal of God witnesses to the development of Christian character, such that "it will be clearly understood that Jesus has redeemed them from all iniquity." "Incomplete" obedience would make it impossible for believers to endure the time of testing. ${ }^{68}$ Leading early Adventist theologian J. N. Andrews likewise states that the names of those believers who "but partially overcome" are

${ }^{65}$ Jones, The Consecrated Way to Christian Perfection, 124. See p. 158 above.

${ }^{66}$ See pp. 170-174 above.

${ }^{67}$ Brunson, "Preparation for Translation," 39, 79. See pp. 171-173 above.

${ }^{68} \mathrm{~J}$. Bates, Vindication of the Seventh-day Sabbath, 214; idem, Second Advent Way Marks, 106. Emphasis original. See pp. 28, 26 above. 
removed from the book of life in the judgment. ${ }^{69}$ The strong views of John Brunson at the 1899 General Conference session in regard to the need for a unique cessation of sin on the part of those preparing for the time of trouble cannot be considered extreme, when one takes into account the positive reports of the effect of his message, and the fact that he was invited to write a reading for the Week of Prayer later that year. ${ }^{70}$ Other evidence that entire overcoming of sin was a major view at the time Andreasen began work for the denomination is the 1905 publication in the Review of church administrator A. T. Robinson's idea that the 144,000 would be free from sin for a year, as well as pioneer S. N. Haskell's testimony at the 1909 General Conference session regarding the purpose of the placing of the prophetic gift in the Adventist church - "to perfect a people that they may be blameless." 71

Though there seems to have been a consensus of belief regarding the perfect overcoming of the end-time saints, there are hints of dissent. J. H. Waggoner, while visiting some of the dissident groups in Iowa in 1861, was dismayed to find some denying that the church would be brought into a state of perfection before the end, or that perfection was needed in order to stand during the time of trouble. ${ }^{72}$ And in the $1930 \mathrm{~s}$, Meade MacGuire found it necessary to instruct "many who cannot grasp the idea that 94 above.

${ }^{69}$ Andrews, "The Order of Events in the Judgment - Number Five," 188. See p.

${ }^{70}$ See pp. 171-174 above.

${ }^{71}$ Robinson, "Our Message,” 9; Haskell, "The Spirit of Prophecy,” 229. See pp. 173-174 above.

${ }^{72}$ J. H. Waggoner, "Meetings in Southern Iowa," 76. See pp. 108-109 above. 
there is any possibility of ever stopping our habitual sins." 73

Indeed, moderating voices on the subject of end-time perfection have been noted in this study. Uriah Smith's considerably nuanced answer to critics of Adventism's focus on preparing for the Advent has been noted, in which he apparently attempts to disown the idea of a unique standard of moral character for the last generation. ${ }^{74}$ Likewise, it has been noted that James White had much less to say about character perfection than did his wife. And when he did address the topic directly, it is in the context of noting divisions created among the early Adventists by the "extreme views" of Christian perfection held by the Methodists and others. ${ }^{75}$

During the 1930s, when the sanctuary message was under attack and Andreasen was coming to the front as an exponent of Adventist sanctuary doctrine, even stronger moderating voices began to be heard. None other than the General Conference president, C. H. Watson, in his apologetic work, The Atoning Work of Christ, rejects the idea that believers who stand through the time of trouble "depend on the perfection of their own lives." Rather, the saints stand "not by anything we have done, but by being in God and having God in us." ${ }^{\text {76 }}$ And W. H. Branson, a vice-president of the General Conference, though he clearly stood for a behavioral standard (of right doing) in the final judgment, as

${ }^{73}$ MacGuire, “The Cleansing of the Sanctuary,” 9. See pp. 190-191 above.

${ }^{74}$ See pp. $98-101,260-261$ above.

${ }^{75}$ J. White, Life Incidents, 155. See p. 91 above.

${ }^{76}$ Watson, Atoning Work of Christ, 214. See pp. 194-195 above. Watson's words here are based on 1 John 4:16-17, and in Watson's context seem to point to a close relationship, including dependence on Christ for righteousness. 
opposed to the scrutinizing of one's confessions and repentance, allows for the imputed righteousness of Christ to make up for character deficiencies in the judgment.

Accordingly, believers may be acquitted in the judgment either on account of faithenabled law-keeping, or, "failing this," "Christ's righteousness as a covering for his failure." ${ }^{77}$ If Branson meant to apply this last provision to the last generation, it would certainly militate against Andreasen's understanding of the purpose of the sanctuary-to eradicate sin rather than to merely forgive it. ${ }^{78}$

\section{The Meaning of Sins Blotted Out}

Though there seems to be general agreement between Andreasen and at least a large body of influential Adventist thinkers regarding the need for overcoming all sin in order to be ready for coming events, there is less agreement on the meaning given to the blotting out of sins on the antitypical Day of Atonement, just as was seen when comparing Ellen White's and Andreasen's views. ${ }^{79}$ There appears a lack of consensus among Adventists throughout the period in regard to what is required in order for sins to be blotted out in the antitypical Day of Atonement. Some point to confession of sin, others to the overcoming of sin, and some acknowledge both aspects.

J. N. Andrews, while maintaining that both the confession and the overcoming of sins were needed before such could be blotted out, gave early shape to an Adventist

\footnotetext{
${ }^{77}$ Branson, The Atonement in the Light of God's Sanctuaries, 75. See p. 196 above.

${ }^{78}$ See pp. $230-232$ above.

${ }^{79}$ See pp. 240-259 above.
} 
theology of eradication of sins from the lives of believers in connection with the end-time cleansing of the sanctuary. ${ }^{80}$ Andrews apparently makes the perfection of one's "work of overcoming" sin the key determinant used in deciding whether sins may be blotted out in the judgment: "We need [Christ] ... to show from the record of our past lives that we have perfected the work of overcoming, so that our sins may ... be blotted out." Furthermore, "all that have failed to overcome are stricken" from the book of life. ${ }^{81}$

Uriah Smith, writing eight years earlier, in 1861, judged the criterion for having one's sins blotted out in the judgment quite differently. Where Andrews identifies perfect overcoming, Smith points to repentance as the primary criterion. For Smith, a "book of records" is investigated in order to determine "character." But it is repentance of sin that is noted in this investigation, rather than the overcoming of the sin: "The sins of those who have repented will be blotted out ...; while the sins of those who have not sought forgiveness and pardon, will stand against them." ${ }^{12}$ This is termed an "investigation of character" by Smith, and seen as fulfilling the parable of the wedding, in which the guest who arrives without a wedding garment is rejected. Smith's subsequent identification of the wedding garment as "righteousness," or "right doing," serves only to confuse the matter, if one approaches the question from Andreasen's point of view.

${ }^{80}$ According to Andrews, the blotting out of sins pertains "only to those who have fully repented of their sins, and have perfectly accomplished the work of overcoming." Andrews, The Judgment, 20. See p. 93 above.

${ }^{81}$ Ibid., 35-36. As pointed out above, "failed to overcome" is rendered more strongly - "but partially overcome"-in the 1869 version. Cf. Andrews, "The Order of Events in the Judgment - Number Five," 188. See p. 94 above.

${ }^{82}$ U. Smith, "The Wedding Garment," 156. See pp. 98-99 above. 
As seen above, Andreasen identified the Holy Place ministry with repentance and forgiveness, and the Most Holy Place ministry with sanctification and the overcoming of sin. As wonderful as is forgiveness, it does not fulfill the real purpose of the sanctuary, in Andreasen's thinking. ${ }^{83}$ Uriah Smith's article on the wedding garment is actually closer to Ellen White, who highlights repentance and confession of sin as the key element in determining one's ability to stand during the time of trouble, though she also clearly states in other contexts that a perfect reflection of Christ's character is likewise required ${ }^{84}$ This seeming ambiguity (from an Andreasenian standpoint) is maintained by Smith, but overcome by Andreasen, Andrews, and others.

R. F. Cottrell may have been one of these who saw overcoming of sin as a precondition for its blotting out. As he closed an article on the Day of Atonement, in an 1884 series on the sanctuary, he appealed to his readers: "If we have faith ..., deny ourselves . ., consecrate ourselves ..., and labor ..., we shall have our sins blotted out. ${ }^{{ }^{85}}$ Later writers paved the way for Andreasen by pointing out that sinning among believers had to cease before the sanctuary services could be ended. It was actually Andrews who early had pointed out that Christ "is not needed as priest after" the sins of the righteous are blotted out. ${ }^{86}$ A. T. Jones made the case even stronger, arguing from the OT yearly service and the "end of sins" spoken of in Dan 9:24 that the sanctuary could

${ }^{83}$ See pp. $252-253$ above.

${ }^{84}$ See pp. $253-257$ above.

${ }^{85}$ Cottrell, "The Cleansing of the Sanctuary - No. 4," 219. See p. 104 above.

${ }^{86}$ Andrews, The Judgment, 20. See p. 93 above. 
not be cleansed from sin until "the stream that flowed into the sanctuary" was stopped. ${ }^{87}$ Meade MacGuire, also taking Dan 9:24 as applying to the end-time cleansing of the sanctuary, continued along the same lines when he strongly appealed to the delegates at the 1930 General Conference session to let the work of overcoming sin be finished in their lives, since "as long as the stream goes up and Jesus ministers, the sanctuary cannot be cleansed and the work up there finished." ${ }^{98}$

Such reasoning is quite transparent, and forms a strong foundation for Andreasen's subsequent work. But the view of repentance and confession of sin as the primary focus of the blotting out of sins in the antitypical cleansing of the sanctuary was by no means extinct in the years leading up to Andreasen's Sanctuary Service. Walter Read, in a 1932 Review article on the investigative judgment and the blotting out of sins, counseled members, "If we keep our sins confessed every day, then when our names are called in the judgment, we shall pass the great test." 89 And C. H. Watson, during the Fletcher crisis in Australia, interpreted the blotting out of sins as a bringing to light and confessing of unconscious sins. ${ }^{90}$

\section{Restoration of Aspects of the Pre-Fall Human Condition}

Related to the concept of blotting out of sin, in some of the Adventist literature, is

${ }^{87}$ Jones, The Consecrated Way to Christian Perfection, 118-119. See p. 157 above.

${ }^{88}$ MacGuire, "The Cleansing of the Sanctuary," 9. See p. 191 above.

${ }^{89}$ Read, "Studies on the Sanctuary - No. 9," 10. See p. 196 above. Read does not make any direct reference to the overcoming of $\sin$ in the article.

${ }^{90}$ See p. 194 above. 
the idea of a restoration of aspects of the unfallen human state. Andreasen's general views in regard to restoration are shared by other Adventist writers, besides Ellen White, if not his concept of the sin-neutralizing change that takes place at the point of forgiveness. ${ }^{91}$ E. J. Waggoner understood the blotting out of sins in a rather literal sense, as the "erasing of it from the nature, the being of man," so that sin is "foreign" to the "new nature" of believers. ${ }^{92}$ This seems rather close to the sinless-nature view of the "holy flesh" movement, in which the "nature which Adam received in the fall" is taken out, and the "nature which Adam had before he fell" is restored, though Waggoner criticized this sinless-nature understanding of the final generation. ${ }^{93}$

Other writers looked at in this study that envisioned a restoration of some aspect of the pre-Fall human condition include John Brunson and W. H. Branson. In his yearending Week of Prayer reading in 1899, Brunson stated that only when believers are "restored to that complete harmony with God which was enjoyed by man before he sinned" could there be no further need of mediation." ${ }^{94}$ And Branson, writing two years before Andreasen's Sanctuary Service was published, shows that he understands the final generation's nature to be changed in a rather material way. Christ is said to bring His "power to bear upon the weak tendencies" of human nature, where His imparted righteousness "actually touches our flesh and brings its actions into harmony with God's

${ }^{91}$ See pp. 231-232, 244-248 above.

${ }^{92}$ E. J. Waggoner, “The Blotting out of Sin,” 8. See p. 165 above.

${ }^{93}$ Donnell, "The Nature of Christ and Man,” 28. See pp. 168, 165-166 above.

${ }^{94}$ Brunson, "Prepare for Translation," 79. See pp. 172-173 above. 
law." ${ }^{95}$ Regardless of the mechanism or the extent of change, Andreasen is certainly not unique in anticipating a restoration of some aspect of the pre-Fall state.

\section{The Role of Christ in Showing the Way}

Andreasen's theology depends on humans being able to duplicate what Christ accomplished in His life. ${ }^{96}$ Therefore an understanding of both the nature of Christ and of humanity is important, and is related to the discussion of the nature of the blotting out of sins and the restoration of the image of God. Though the nature of Christ's humanity was not a matter of debate in Adventist circles during the period under investigation, it is easy to find clear precedents to Andreasen's view in the writings of A. T. Jones, E. J.

Waggoner, W. W. Prescott, and even W. H. Branson.

Jones and Waggoner clearly expected the life of Christ to be replicated in the lives of believers, especially at the end of time. Jones saw Christ as a demonstration of what God can do when He takes possession of sinful flesh, so that "instead of sin manifesting itself," God's power and glory are seen. ${ }^{97}$ Waggoner is more explicit, nearly paralleling the position of Andreasen when he points out that Christ cannot be a "unique specimen"; rather, "the life of Jesus is to be perfectly reproduced in His followers. ... God will demonstrate to the world that what he did with Jesus of Nazareth He can do with anyone

\footnotetext{
${ }^{95}$ Branson, The Atonement in the Light of God's Sanctuaries, 94-96. See pp. 196-
} 197 above.

${ }^{96}$ See pp. 232-234 above.

${ }^{97}$ Jones, “The Third Angel's Message, No. 15,” 303. See p. 154 above. 
who will yield to Him. ${ }^{98}$ Such an understanding of the possibilities of overcoming imply that the human nature of Christ and of fallen humanity must be very similar, if not identical. Though Andreasen very rarely uses the term "sinful flesh," his conclusions seem to require that Christ partake of fallen nature to give humans an example of what is possible in such flesh. In fact, this is what Jones sees as the purpose of the OT sanctuary service — to demonstrate "how [God] would Himself dwell in the temple of Christ's body, among sinful men and in sinful flesh." ${ }^{.99}$ Since Christ overcame sin completely in sinful flesh, believers may expect the same outcome, given the same degree of yielding and submission to God. Jones interprets this as included in the third angel's message, which is to prepare believers for translation. ${ }^{100}$

The understanding that believers can overcome all sin through the power of an indwelling Christ was not restricted to Jones and Waggoner, though. W. W. Prescott also upheld the view of the indwelling "divine life working in sinful flesh to give victory over sin," as did W. H. Branson, who exhorts readers to let Christ "live His life of perfect obedience to the moral law of God in your flesh." ${ }^{101}$

${ }^{98}$ E. J. Waggoner, "The Sanctuary of God," 774. See p. 163 above. Cf. Andreasen: "Men are to follow His example and prove that what God did in Christ, He can do in every human being who submits to Him. The world is awaiting this demonstration." Andreasen, The Sanctuary Service, 299. See p. 233 above. Cf. also: "The question would naturally arise as to whether His victory was merely a singular demonstration made possible by His unique relation to the Father or whether others could do what He had done." Idem, The Book of Hebrews, 58. See p. 213 above.

${ }^{99}$ Jones, “The Third Angel's Message, No. 25," 447. See p. 155 above.

${ }^{100}$ See pp. 154-156 above.

${ }^{101}$ Prescott, "Modern Babylon Substitutes Paganism for Christianity (Continued from Dan. vii.)," 375; Branson, The Atonement in the Light of God's Sanctuaries, 96. 
It is interesting that Andreasen does not seem to follow Jones and Waggoner in their understanding of the effects of the indwelling of God on the physical human nature. Both Jones and Waggoner expected human flesh indwelt by God to be beyond the reach of death. Waggoner expected "to live forever," and Jones held that believers who really keep the commandments "will never die." ${ }^{\prime 102}$ But Andreasen does not mention anticipated effects of the divine indwelling on the physical nature. Andreasen also does not emphasize a pre-probationary, human-to-human witness of believers who live sinless lives in sinful flesh, as does Waggoner. ${ }^{103}$ Andreasen is focused more on the witness believers give on behalf of God during their severe trial after the close of probation.

\section{Summary}

The views of Andreasen, then, find antecedents in other writers besides Ellen White. The expectation of complete victory over sin on the part of the last generation seems to have been widespread throughout the short history of the Adventist believers. There is some discussion, though, regarding the uniqueness of this preparation for the end. And there are moderating voices that seem hesitant to lay much stress on perfection. Andreasen is squarely in the company of Jones and Waggoner with respect to the eschatological significance of this end-time overcoming, characterized by the view that the blotting out of sins in the antitypical Day of Atonement is concerned with eradicating

See pp. 186, 197 above. 164, 151 above.

102 "Eleventh Meeting," 53; [Jones], "Fifth Righteousness Sermon," 5. See pp.

${ }^{103}$ E. J. Waggoner, "Sermon, April 6," 147. See pp. 163-164 above. 
sin from the lives of believers. But others emphasize confession of sin as the key factor in this blotting-out ministry, notably Andreasen's contemporaries C. H. Watson and W. E. Read.

The importance of Christ's coming into fallen humanity to give an example of overcoming is highlighted alike by Andreasen, as well as Jones and Waggoner. Language that Andreasen uses in this regard is very close to that of Waggoner. Related to this idea of God indwelling fallen humanity in the person of Christ is the more widely expressed view regarding the significance and effect of the indwelling of the divine on human lives, especially in the post-1888 era.

It seems most likely from this analysis that Andreasen's theology of complete overcoming of sin in the last generation is based on the views of other Adventist writers, first of all, Ellen White, and then A. T. Jones and E. J. Waggoner. Other writers who link the cleansing of the sanctuary to the perfection of the final generation seem to follow closely in the wake of Jones and Waggoner. The one intriguing exception is J. N. Andrews. What is important about Andrews's views is not that he expected a high degree of holiness - the overcoming of all sin—on the part of those expecting to be translated; this seems to have been the general understanding of the early sabbatarian Adventists. Rather, Andrews is significant in that he may have been the first to suggest that cessation of mediation in the sanctuary above may be considered to be dependent on the cessation of $\sin$ in the final generation. ${ }^{104}$

This step in Adventist theology was not taken as quickly as one might expect,

${ }^{104}$ See pp. 265-266 above. 
possibly due to Ellen White's emphasis of prior confession of sins as the condition for the blotting out of sins on the antitypical Day of Atonement. To be sure, many writers, including White, emphasize cessation of sin and cessation of mediation in the sanctuary. But usually it is the cessation of mediation that is seen to call for a high degree of holiness. What is intriguing about Andrews, in connection with the later Jones-Waggoner and Andreasen emphasis, is that his language makes it possible to see the cessation of mediation as dependent on the blotting out of sins, which, in turn, is dependent on the complete overcoming of sin by believers: "This work of blotting out sins brings our Lord's priesthood to an end. He must be priest till then. He is not needed as priest after that." ${ }^{105}$ It is not that God's people have little time to prepare, but that Christ is unable to bring His intercessory work to a close while believers continue to sin. This thought may not have been Andrews's intention, but such language is quite similar to that of writers like Jones, MacGuire, and Andreasen, who developed the thought more completely. ${ }^{106}$ From this comparative exercise, it seems clear that Andreasen's view regarding the overcoming of sin by the last generation is certainly not unique, as it was anticipated from the earliest days of Adventism. And even in his linking of final-generation overcoming with the cleansing of the sanctuary, he is not only found to be in harmony with the views of A. T. Jones and E. J. Waggoner, but also lies in a line of theological development extending back to Joseph Bates and J. N. Andrews.

${ }^{105}$ John Nevins Andrews, "The Order of Events in the Judgment - Number Three," Advent Review and Sabbath Herald, November 23, 1869, 172; idem, The Judgment, 20. See pp. 92-98 above for a discussion of Andrews's views. 268 above.

${ }^{106}$ For related expressions of Andreasen, Jones, and MacGuire, see pp. 225, 266- 


\section{Challenge and Vindication}

The correspondence between the views of Andreasen and other Adventist writers on the other aspect of final-generation theology — the challenge to God's rule and His vindication in the successful testing of the end-time saints-is less clear. Here Andreasen pushes forward ideas that only occasionally surface in previous writers. It is the goal of this section to discover and analyze first any relationships that may exist between Andreasen's positions and those of Ellen White, and then between Andreasen and other Adventist writers up to 1937, the year of the publication of Andreasen's The Sanctuary Service.

Compared with the Writings of Ellen White

Andreasen's views are based in large part on the writings of Ellen White. Among the most prominent themes in her writings is that of the "great controversy" between good and evil, forming the backdrop of earth's history. This cosmic struggle between the forces of Christ and Satan is centered on the law of God, and ends with a vindication of the justice and benevolence of God's rule. Andreasen's final-generation theology gives end-time believers a critical role in vindicating the justice of God. White also underlines the importance of God's vindication in the controversy over His law. This section is a comparative analysis of the views of Andreasen and White related to the charges brought against God by Satan, and the role of the end-time saints in vindicating God in the face of these charges.

\section{God's Rule Challenged}

Both Andreasen and White emphasize the seriousness of the charge brought 
against the rule of God by Lucifer. Andreasen follows White quite closely in finding an explanation of end-time events in the charges brought by Lucifer before the creation of humans. Just as Andreasen inserts into his "Last Generation" chapter a section detailing the charges of Satan against God's government, so White, after presenting the sanctuary and judgment, turns to the origin of evil in her Great Controversy. ${ }^{107}$ Lucifer's charge in heaven that the law of God was impossible to keep is noted by both White and Andreasen. In his “Last Generation” chapter, Andreasen notes Satan's charge that God is unjust, requiring "His creatures to do that which they cannot do." 108 And White points out that humans also charge God with injustice when they "say that it is not possible to live a perfect life." Sinners cast "reproach" on God when they blame their behavior on "natural tendencies." 109

This challenge over the fairness of God's law serves as the foundation for Andreasen's last-generation theology. In his description of the controversy's origin in heaven, though, he does not comment on the other charge of Lucifer, described by White in The Desire of Ages, that "man could not be forgiven."

\footnotetext{
${ }^{107}$ Andreasen, The Sanctuary Service, 304-310; E. G. White, Great Controversy, $492-504$.

${ }^{108}$ Andreasen, The Sanctuary Service, 316. See p. 208 above.

${ }^{109}$ E. G. White, “Need of Self-Surrender," Manuscript Releases," 1:369; idem, "Advancing in Christian Experience," 122. See pp. 135-136 above. Neither White nor Andreasen differentiate between fallen and unfallen nature when discussing God's justice in requiring obedience. This is another indication of the lack of concern on their part for anthropological and Christological questions that would later come to dominate Adventist theology.

${ }^{110}$ E. G. White, Desire of Ages, 761. See pp. 144-145 above.
} 
forgiving sinners may appear in Andreasenian thought to be irrelevant for the final generation, it plays a rather large, continuing role in White's descriptions of end-time events. Both just before and after the close of probation, Satan is seen by White to be accusing God of unfairness in forgiving and accepting believers, while he is allowed to perish. In the pre-probationary sealing time, White portrays the devil asking, "Will God banish me and my angels from His presence, and yet reward those who have been guilty of the same sins?" Likewise, during the time of trouble, Satan complains "that the Lord cannot in justice forgive [believers'] sins and yet destroy him and his angels." ${ }^{\prime 11}$ Thus, in White's account of closing events, a perfect final generation does not constitute an answer to all the questions that the devil has brought forward in the great controversy.

Both Andreasen and White consider that the charges of Satan must be answered. White asserts that it was "necessary" for God to "vindicate his justice and the honor of his throne." 112 Andreasen agrees, but seems quite concerned to show that God is not "forced" by circumstances, but is instead "anxious" to let Satan have an opportunity to show "what he can do." 113

\section{Christ as the Answer}

There is also at least superficial agreement between Andreasen and White's

${ }^{111}$ E. G. White, Testimonies, 5:474; idem, Great Controversy, 618. See pp. 81, 74 above.

${ }^{112}$ E. G. White, Spirit of Prophecy, 4:320. See p. 73 above.

${ }^{113}$ Andreasen, The Faith of Jesus and the Commandments of God, 558. See p. 209 above. Andreasen's thought could be that although God needed to answer Satan's charge, for the good of His creatures, the manner in which He chose to respond was of His own will. 
position that Christ was the primary divine response to the charge that the law was too difficult for humans to keep. Andreasen holds that in Christ's life God "demonstrated ... the possibility of keeping the law," and that when Christ died without sinning, Satan knew "his own doom was sealed."114

White tends to lay greater emphasis on the role of Christ in vindicating the law, describing His life as "a most perfect and thorough vindication" of God's law. ${ }^{115}$ Furthermore, immediately after stating that Christ "obeyed the law of God, vindicating God's justice in demanding that it be obeyed," White declares that "in the judgment His life will be an unanswerable argument in favor of God's law." 116 This appears to be in contradiction to Andreasen's concept of the character perfection of the end-time saints as the vindication of God's justice in requiring that the law be kept. At the minimum, it does not strengthen Andreasen's case, since White describes Christ's life as an "unanswerable" argument in the context of the judgment, as conclusive evidence that the law can be kept. Even in describing events occurring after the millennium White points to the cross as the source of God's vindication, declaring that "God's justice [will stand] fully vindicated" when "the great sacrifice" of God is clearly presented to the world. ${ }^{117}$

${ }^{114}$ Andreasen, The Sanctuary Service, 309-310. See p. 210 above.

${ }^{115}$ E. G. White, "Christ and the Law," 513 (1). See p. 83 above.

${ }^{116}$ E. G. White, MS 38, 1893, excerpt in In Heavenly Places, 38. See p. 145 above.

${ }^{117}$ E. G. White, Spirit of Prophecy, 4:486. See p. 76 above. 


\section{Renewed Challenge after the Cross}

Not all questions in the great controversy were answered at the cross, though, Andreasen and White agree. White states that humans and angels did not fully understand "all that was involved in the great controversy" even after the cross. "The principles at stake were to be more fully revealed."118 Andreasen similarly points out that even after the cross "God did not destroy Satan. The demonstration must be completed." 119

The way that the ensuing resumption of the battle is characterized is rather different, though. Andreasen pictures the devil as having one "last opportunity" to at least prevent total defeat, with "everything” at stake. In addition, Andreasen pictures God as having "staked His government" "on the production of one or more who keep the commandments." ${ }^{120}$ Satan reasons that though he failed with Christ, if he can still overcome humanity, "he might not be defeated."121 As noted previously, Dwight Haynes has suggested that Andreasen may be relying on two White statements using the word "triumph." If Christ had yielded to the temptation to save Himself, Satan "would have triumphed, and the world would have been lost." Similarly, describing the time of trouble, "If he could blot [the little company of commandment-keepers] from the earth,

${ }^{118}$ E. G. White, Desire of Ages, 761.

${ }^{119}$ Andreasen, The Sanctuary Service, 306. See p. 211 above.

${ }^{120}$ Andreasen, The Faith of Jesus and the Commandments of God, 557; idem, The Sanctuary Service, 316. See pp. 212-213 above.

${ }^{121}$ Andreasen, The Sanctuary Service, 310. See p. 211 above. 
his triumph would be complete." 122 But in this last instance, there is no mention of the world being lost, as in the former. And in context, the most obvious meaning is that if Satan could destroy the remaining "little company" of commandment-keepers, the entire human race would be under his control—a "complete" triumph at the time, whether or not the whole world is lost to God. ${ }^{123}$ Thus if Andreasen is using these instances of "triumph" in this way, it is probably reading more into them than is warranted.

More problematic to finding a correspondence between White and Andreasen on the significance of the last generation is the rather different focus of the last struggle. Andreasen understands it as God allowing Satan to test out his hypothesis that believers are obeying only because he does not have free access to them, and that they will disobey if allowed to listen to Satan's reasoning and make up their own minds freely, since the law is impossible for humans to keep anyway, except perhaps in extraordinary cases. White, on the other hand, expresses the last struggle as Satan's attempt to deceive believers, while God is attempting to "draw" a "covering" over believers to protect them during the falling of the last plagues. And Satan is intent on preventing this, since after they are sealed they are beyond his power. ${ }^{124}$ White is more likely to express the battle as over the faith and confidence of the last generation, rather than their obedience, which she 212 above.

${ }^{122}$ E. G. White, Desire of Ages, 486; idem, Great Controversy, 618. See pp. 211-

${ }^{123} \mathrm{Cf}$. other early uses of "triumph" by White: "O what triumph of Satan . . !" when the disciples forsook Christ in Gethsemane; Satan enjoyed a "little moment of triumph" when Christ lay in the tomb. E. G. White, Spiritual Gifts, 1:48, 67.

${ }^{124}$ E. G. White, Early Writings, 43; idem, “A Vision God Gave Me,” 8:220. See pp. 36, 43 above. 
speaks of often, but, curiously, not in connection with Satan's efforts to overthrow them during the post-probationary time of trouble. ${ }^{125}$

\section{Dependence on Witnesses}

Andreasen's argument that God depends on the witness of His people to clear Him of Satan's charges is made very specifically and clearly in his "Last Generation" chapter. His use of Job as a type of the last generation is ostensibly based on the book of James, where the word "patience" occurs in connection with both end-time saints and also the story of Job. ${ }^{126}$ Andreasen sees the last generation as witnesses called forth by God in order to silence Satan's arguments, just as God depended on Job to silence the devil's charge that Job was only serving God for self-gain.

White's treatment of the time of trouble is noticeably different, though there are some corresponding elements. Andreasen's choice of Job as a type of the 144,000 may be based on White's use of Job as an example of a character witness used by God in His long-standing controversy with Satan. ${ }^{127}$ Also, White holds up Enoch as someone whom God "selected ... to evidence to the world that it is possible for a person to keep all the law of God" and to "demonstrate to the universe the falsity of Satan's charge that human beings cannot keep God's law." "128 This is markedly similar language to that of Andreasen. Though White does not directly attribute the role of demonstrating the justice

${ }^{125}$ See pp. 74-75, 148-150 above.

${ }^{126}$ See pp. 214-215 above.

${ }^{127}$ See pp. 146-147 above.

${ }^{128}$ E. G. White, "MS, 1900, in Christ Triumphant," 51. 
of God's law to the last generation, she does declare that Enoch's "godly character ... represents the state of holiness which must be attained" by them. ${ }^{129}$

Another area of superficial agreement is on the fact of a struggle going on in the unseen world, with believers unaware that they are the focus of this battle. But here the differences begin to outweigh the similarities. For Andreasen, it is Job who is unaware of how much God is depending on him to silence Satan's charges. ${ }^{130}$ White instead chooses the story of the high priest Joshua, dressed in his filthy rags, to reveal the invisible controversy over the human race. ${ }^{131}$ And in the special context of the time of trouble, it is the story of Jacob wrestling with the angel, his conscience accusing him, that is used as an illustration of the trial of God's people. Even in places where it would be easy to refer to Job's example, as when White speaks of Satan being allowed to try the 144,000 "to the uttermost," Job is not mentioned. ${ }^{132}$ Thus, simply by the biblical examples chosen to reveal the experience of believers, a different picture emerges. Further dissimilarities become apparent as Andreasen and White describe the experience of the final generation.

\section{The Final Demonstration}

While there exist many parallels in the descriptions of God's end-time people in the writings of Andreasen and White, there are also quite clear differences. Andreasen sees the final battle as "the most sweeping and conclusive demonstration of all the ages of

${ }^{129}$ E. G. White, Patriarchs and Prophets, 88-89. See also p. 142-144 above.

${ }^{130}$ Andreasen, "Patience of the Saints," 24. See pp. 215-216 above.

${ }^{131}$ See pp. $79-81$ above.

${ }^{132}$ E. G. White, Great Controversy, 618. 
what God can do in men." ${ }^{133}$ White also very early showed an awareness of a great battle approaching, with the forces of good and evil engaged, but reserves superlatives for the intensity of the believers' trial and the calamities that fall on unbelievers. ${ }^{134}$

Nevertheless, there appears to be a high degree of correlation between the views of Andreasen and White in regard to the complete sanctification of the final generation. Andreasen envisions the bringing forth of a "finished product" of the gospel, a "completely sanctified" people, a demonstration never given to the world before "on any adequate scale." ${ }^{\prime 35}$ White also sees Christ's work of character transformation carried forward to "glorious perfection," when Christ's mercy, love, and grace "appear in full and final display" in His church, mystifying Satan and astonishing angels. ${ }^{136}$ Moreover, White clearly associates the honor and glory of Christ with the perfection of the church. And as Andreasen links the sealing to the cessation of sin, White similarly restricts the seal of God to those with spotless characters: "Those who receive the seal of the living God ... must reflect the image of Jesus fully."137

However, when Andreasen and White describe the test that the final generation

${ }^{133}$ Andreasen, The Sanctuary Service, 303. See p. 222 above.

${ }^{134}$ See pp. 37-38 above. For the severity of the trial, see E. G. White, Great Controversy, 613, 622 .

${ }^{135}$ Andreasen, The Faith of Jesus and the Commandments of God, 11, 563; idem, The Sanctuary Service, 301. See p. 219 above.

${ }^{136}$ E. G. White, Spirit of Prophecy, 3:261; idem, Desire of Ages, 680. See pp. 68, 143-144 above.

${ }^{137}$ E. G. White, Early Writings, 71. In later writings, White suggests that the image of Christ may need further polishing after the sealing, during the time of Jacob's trouble, when believers' "earthliness must be consumed, that the image of Christ may be perfectly reflected.” Idem, Great Controversy, 621. 
undergoes during the time of trouble, they appear to diverge considerably. For Andreasen, what is at issue during the time of trouble is whether the weakest believer can obey the law of God and live without sinning, even while suffering in a way approaching to that of Christ at His trial and execution. The result of this ultimate demonstration would be that all excuses for sin would cease. ${ }^{138}$

White sees the issues differently, it seems. As to the state of perfection of the final generation, White's statements suggest that believers undergoing the time of trouble may be in need of further improvement: "Their earthliness must be consumed, that the image of Christ may be perfectly reflected." ${ }^{\text {"139 }}$ Furthermore, White portrays Satan as continuing to accuse believers of being no more worthy of God's favor than he; they themselves are "fully conscious" of their "unworthiness," and have "a deep sense of their shortcomings. ${ }^{.140}$

Beyond pointing out the perceived lack of worthiness on the part of the last generation, White specifies different issues at stake than does Andreasen. Rather than describing the final test in terms of the ability of ordinary believers to live without sinning, White seems more concerned with the ability of believers to maintain their faith and confidence. The temptations prepared for them at this point are designed to terrify them with their inadequacies, and cause them to give up their faith. They see "little good" in their "whole lives," and "as they review the past, their hopes sink." White

${ }^{138}$ See pp. $220-223$ above.

${ }^{139}$ E. G. White, Great Controversy, 621. See p. 71 above.

${ }^{140}$ Ibid., 618-619; E. G. White, Patriarchs and Prophets, 202. See pp. 75, 148149 above. 
depicts believers in the time of trouble, like Jacob in his distress, as "dependent, helpless, repenting sinners." ${ }^{.141}$ And as Satan accuses the final generation "on account of their sins, the Lord permits him to try them to the uttermost. Their confidence in God, their faith and firmness, will be severely tested." ${ }^{142}$ Though the outcome may be the same for Andreasen and White, the language used suggests a different concern. In White's portrayal, Satan's goal is to cause the last generation to "turn from their allegiance to God." ${ }^{143}$ Turning "from their allegiance to God" may easily be re-stated as causing to transgress the law and commit sin at some point, but the sum of the expressions White uses in her narrative of the time of trouble suggests that she differs from Andreasen in her understanding of the significance of this testing time.

Harmonizing with this seemingly less triumphant view of the remnant is another concern, that of the ability of God to justify His pardoning of repentant believers. This correlates with what White states as the other half of Lucifer's charge when the controversy broke out in heaven, "that, should the law be broken, it would be impossible for the sinner to be pardoned." "144 Satan accuses God of injustice and favoritism in the pardons given to believers. ${ }^{145}$

On the difficulty of the test the last generation undergoes, there is close agreement between Andreasen and White. Both portray the saints seemingly abandoned, in an

${ }^{141}$ E. G. White, Spiritual Gifts, 3:132. See pp. 56-57 above.

${ }^{142}$ E. G. White, Great Controversy, 618-619.

${ }^{143}$ Ibid., 619. See p. 75 above.

${ }^{144}$ E. G. White, Desire of Ages, 761. See also pp. 276-277 above.

${ }^{145}$ See pp. 74-75, 81-82, 131 above. 
experience similar to Christ's on the cross. Andreasen has the saints crying to God, who hides Himself and "appears not to hear," as the believers have "a little taste of Christ's experience those three hours on the cross. ${ }^{.146}$ White likewise reveals the saints, as they feel abandoned, remembering "Jesus dying upon Calvary's cross."147 The angels are seen by both White and Andreasen as prevented from providing help at some point,,${ }^{148}$ though the saints receive "food, safety, grace, and power," according to Andreasen, and White declares that Christ "will send help just when [they] need it." ${ }^{149}$

\section{Vindication of God}

The final demonstration given in the lives of the last generation serves to vindicate God in the cosmic conflict between good and evil, according to Andreasen. The ultimate vindication of God is a very important theme in the writings of both Andreasen and White. Andreasen stresses that God's vindication is more important than human salvation, and White writes of the concern of the final generation for God's honor, depicting believers during the time of trouble as very concerned over the possibility of God's name being reproached if they are found to be unworthy on account of their defects. $^{150}$

But the source of this vindication is not quite the same for both writers.

${ }^{146}$ Andreasen, The Sanctuary Service, 317-318. See pp. 221-222 above.

${ }^{147}$ E. G. White, Great Controversy, 630. See p. 71 above.

${ }^{148}$ See pp. 71-72, 222 above.

${ }^{149}$ Andreasen, The Sanctuary Service, 318; E. G. White, Great Controversy, 633. See pp. 218, 72 above.

${ }^{150}$ See pp. $75,82,222-223$ above. 
Andreasen clearly holds up the last generation of saints as clearing God "of any and all charges which Satan has placed against Him." Again, "In the last generation God is vindicated and Satan defeated."151 However, Ellen White does not show that she shares this definite view, although she does speak of an end-time vindication of God's rule. A search of White's published writings will show many instances in which she identifies Christ as the One who vindicated God's law in His life and death. In her view, the "broader and deeper purpose" for which "Christ came to the earth" was "to vindicate the character of God before the universe." 152 Linking Christ's life and death with the vindication of God, White argues that by suffering the penalty of the law's transgression, Christ "established [the law's] immutability."153

In the 1870 s and 1880 s, White began to emphasize an end-time vindication of God's honor. ${ }^{154}$ In her 1884 version of end-time events, after presenting the pre-Advent judgment, she discusses the origin of evil and the need to vindicate God of the charges brought against Him. She then shows how this is accomplished by means of the cross. ${ }^{155}$ When she expanded her treatment of the origin of evil in her 1888 Great Controversy, White moved the word "vindicate" to an enhanced description of the eradication of evil at

${ }^{151}$ Andreasen, The Sanctuary Service, 303-304. See pp. 207-208, 223-224 above.

${ }^{152}$ E. G. White, Patriarchs and Prophets, 68. For further discussion of Andreasen and White's views on the vindication of God, see Paul M. Evans, "An Analysis of M. L. Andreasen's View of God's Vindication in Relation to the Writings of Ellen White" (term paper, Andrews University, 2002), CAR.

${ }^{153}$ E. G. White, "Redemption - No. 1,” 83. See pp. 66-67 above.

${ }^{154}$ See pp. 66-69 above.

${ }^{155}$ E. G. White, Spirit of Prophecy, 4:320. See p. 73 above. 
the end of the millennium. This eradication had been "made certain" previously at the cross, though, when the great controversy was "decided."156

However, when Ellen White speaks of the end-time vindication of God, she tends to focus more on what God Himself does, and does not seem to share Andreasen's view that God is critically dependent on the last generation for vindication in the great controversy. While Andreasen places more weight on God's use of the role of the final generation, White is more apt to speak of God's vindication in connection with the outpouring of the last plagues, or the efforts of early sabbatarian Adventists to publish the truth about the Sabbath and the perpetuity of the law. ${ }^{157}$

When White does speak of the role of end-time believers in vindicating God's law, the context suggests that her emphasis is rather different from Andreasen's. In her 1885 sermon, “The True Standard of Righteousness," White clearly links end-time believers' attitude to the law with their vindication of God's honor: "God will have a people upon the earth who will vindicate his honor by having respect to all of his commandments." Though by "respect" she certainly intends more than verbal acknowledgment, the purpose of this sermon is to show the deceit of those who claim complete sanctification and yet deny the fourth commandment's validity. Two paragraphs later she points out that these false teachers "make the loudest boast of living holy, sinless lives," contrasting them with Bible heroes, none of whom "claimed to be

${ }^{156}$ E. G. White, Great Controversy, 503. See p. 85 above.

${ }^{157}$ E. G. White, Testimonies, 3:574, 4:593; idem, Great Controversy, 627-628. See pp. 67-68, 87-88 above. 
without sin," but "sorrowful for their sins, have tried to copy the pattern Jesus Christ.", 158 Thus White's context strongly suggests that she does not mean to leave the impression that end-time saints vindicate God by achieving the sinlessness which their detractors claim. Rather, it is their "respect" for the law, in this instance, that is spotlighted as honoring God.

Similarly, in White's 1893 discussion of Joshua and the Angel, end-time believers who stand to "vindicate the holy law of God" are described as "weak and compassed with infirmity," who "turn from disloyalty" and "come back to their allegiance." And although they "will stand perfect before God," this is seen to be "through the righteousness of Christ." 159

Nevertheless, the contrast between White's final generation, that has "respect" for the law, turning from disloyalty to allegiance, and Andreasen's, that vindicates God by ceasing to sin, should not be overdrawn. White herself closely links the concepts of allegiance and sinlessness when discussing Christ's victory over sin: "By faith he laid hold upon divinity, even as humanity may lay hold upon infinite power through him. Altho [sic] tempted upon all points even as men are tempted, he sinned not. He did not surrender his allegiance to God, as did Adam."160 In her 1897 article, "Christ Represents the Beneficence of the Law," White again refers to Satan's accusations against "those above.

${ }^{158}$ E. G. White, “The True Standard of Righteousness," 529 (1). See pp. 83-84

${ }^{159}$ E. G. White, “The Remnant Church Not Babylon,” 546 (2). The previous paragraph suggests imputed righteousness is meant. See pp. 129, 146, 149-150 above.

${ }^{160}$ Ellen G. White, "Sin Condemned in the Flesh," Signs of the Times, January 16, $1896,264$. 
who throw off the Satanic yoke, and come back to render willing allegiance." In the preceding paragraph, White emphasizes the need for a demonstration of God's character, made necessary by the charges of Satan. While Christ "represented the beneficence of the law" in His life, this still needs to be "testified" to the universe. Following Christ, believers will become an "illustration of the divine law," through whom "the far-reaching principles of the law will be demonstrated in humanity." ${ }^{\text {161 }}$ And White clearly holds to the view that God, in His controversy with Satan, makes use of character witnesses like Job, who demonstrate unselfishness in thwarting the charges of Satan. ${ }^{162}$ Thus, while White does not seem to share Andreasen's concern for demonstrating the real possibility of an entire generation ceasing completely to sin, she does focus attention on an end-time demonstration of the principles of the law in the context of the great controversy. However, White's descriptions of end-time events lack a clear linkage between character perfection and the vindication of God, both of which otherwise stand out as familiar themes in her writings. Andreasen's linking of the perfection of the final generation to the vindication of God, then, is not easily based on White's writings. Antecedents for Andreasen's concepts can be discovered much more easily in the writings of other Adventists, as the next section will demonstrate.

\section{Compared with Contemporaneous and Earlier Adventist Writers} When Andreasen's final-generation theology is compared with the writings of 149 above.

${ }^{161}$ E. G. White, "Christ Represents the Beneficence of the Law," 145 (1). See p.

${ }^{162}$ See pp. 146-147 above. 
other Adventist writers besides Ellen White, a few striking similarities are seen, as well as some persistent contrasts. A concern for the urgent need to prepare for translation often dominates, leaving questions about the controversy between good and evil to second place. For example, O. R. L. Crosier, while explaining the need for a final atonement, based on the earthly sanctuary system, does not ask why sins are being transferred to the sanctuary in heaven, only to be returned finally to Satan. ${ }^{163}$ And C. H. Watson seems to turn his attention to theodical aspects of the Day of Atonement ministry in the antitypical Most Holy Place only as a defense of the Adventist understanding of the bipartite sanctuary service. In addition, Adventists may have spent as much effort defending their understanding of Satan as the scapegoat on the Day of Atonement, as they did showing how this ceremony related to theodical concerns. ${ }^{164}$ The exception that stands out is J. H. Waggoner, who early emphasized the need to clear God's name of the charges of injustice that had been raised. In harmony with this view, Waggoner's son Ellet came to see the purpose of the end-time judgment as a revelation of the divine character, rather than primarily an inspection of human characters. ${ }^{165}$

\section{Christ as Vindicator of the Law}

Adventist writers have followed Ellen White in seeing history as the working out of a great struggle between the forces of good and evil. Andreasen sees this struggle as coming to a climax in the experience of the last generation during the post-probationary

\footnotetext{
${ }^{163}$ See pp. 18-20 above.

${ }^{164}$ See pp. 199-200 above.

${ }^{165}$ See pp. 108-113, 160-161 above.
} 
time of trouble. However, the charges raised by Satan against God's law are often regarded as already answered in the life and death of Christ by other Adventist writers, even by those who recognize the need for other human witnesses. W. W. Prescott, for example, just after presenting the story of Job as an illustration of God's use of witnesses in clearing Himself of Satan's false charges, points to the cross as the "climax of the controversy" and the means by which "God's government" is "vindicated before the universe." ${ }^{166}$ The fact that Prescott can acknowledge God's use of human witnesses to aid in clearing His name of the false charges of the enemy, while at the same time recognizing the cross as the great means of God's vindication, evidences that one can appreciate the value of Christ's life and death for the vindication of God, while at the same time conceding a contributory role to Christ's followers. Andreasen's emphasis on the role of the final generation can appear to eclipse the role of Christ, but Prescott is one who takes a similar path to that of Andreasen, yet with quite surprising conclusions, juxtaposing the ideas of vindication by the cross and God's use of human witnesses. ${ }^{167}$ When Christ's life and death are said to vindicate God's government or law, the actual meaning may need to be clarified, as this can be understood in more than one way. A central concern for Adventists, with their view of the seventh-day Sabbath, was to show that Christ's life and death, as well as the teaching of Christ, the apostles, and even end-time Sabbath keepers, served to vindicate the downtrodden law, showing its

${ }^{166}$ Prescott, "The Kingdom of God [Concluded]," 60. See pp. 188 above.

${ }^{167}$ For further comparison of Prescott's and Andreasen's views on God's use of human witnesses, see pp. 296-299 below. 
immutability. ${ }^{168}$ This is a different use of "vindication" than Andreasen's, which requires a demonstration of obedience, and not mere teaching about the law's validity, or even enforcement of its penalty.

Aside from this use of "vindication," which is closely related to denominational apologetics, Adventist writers used the term "vindication" in connection with two complementary charges that have been raised against the divine government, and which deal with more universal, theodical concerns. One is that God, on the side of leniency, pardons sinners by way of ignoring the letter of the law. The opposite charge is that God, on the side of harshness, condemns sinners by enforcing an unreasonable law. ${ }^{169}$ The first problem is addressed by a number of writers, including James White, Uriah Smith, J. H. Waggoner, E. J. Waggoner, and A. T. Jones. ${ }^{170}$ Both the elder and the younger Waggoner are careful to show that Christ vindicated the law by submitting to its penalty Himself. ${ }^{171}$ And both J. H. Waggoner and Jones point out the necessity of Christ uniting the natures of the Lawgiver and the condemned lawbreaker. ${ }^{172}$ This first use of "vindication," in connection with charges of leniency, is closely related to the desire of Adventists to argue the perpetuity of the law, as seen in James and Ellen White's upholding of Christ as the great Vindicator of the law during the 1870 s. ${ }^{173}$

${ }^{168}$ See pp. 97-98, 105, 112-113 above.

${ }^{169}$ E. G. White, Desire of Ages, 761. See pp. 144-150 above.

${ }^{170}$ See pp. 91-92, 111-112, 153-154, 159, 176 above.

${ }^{171}$ See pp. 112, 159 above.

${ }^{172}$ See pp. 112, 154-155 above.

${ }^{173}$ See pp. 66-67, 91-92 above. 
Andreasen's final-generation theology uses "vindicate" exclusively in relation to the second of the two principal charges, that of harshness in condemning sinners for disobedience to an unreasonable law. ${ }^{174}$ By 1898 , Uriah Smith was speaking very directly to this problem. Against the charge that humans "never should have been condemned for breaking" the law, Smith contends that Christ's "whole life ... was a complete and triumphant vindication of the fact that God is not unjust in his demands," leaving humans with no excuse for sin. ${ }^{175}$ While Andreasen acknowledges that Christ "demonstrated that it was possible for man to obey God," he links the removal of excuses for sin to the final generation's demonstration of obedience, rather than Christ's. ${ }^{176}$ Andreasen thus gives a larger role to the last generation, while Adventist writers generally give Christ the leading role in the vindication of God's rule-whether in His teaching (against the charge that the law has been changed), His life (against the charge that God is severe in requiring obedience), or His death (against the charge that God is lenient in pardoning transgressors).

\section{Post-Calvary Vindication}

Andreasen strongly emphasizes that while Satan's fate was sealed at the cross, doubts still remained in the minds of intelligent creatures. Furthermore, Satan believed he had another chance to win if he could overcome Christ's followers. Andreasen seems to agree, when he states that "God has staked His government" "on the production of one

${ }^{174}$ See pp. 207-209 above.

${ }^{175}$ U. Smith, Looking Unto Jesus, 29-30. See p. 177 above.

${ }^{176}$ Andreasen, The Sanctuary Service, 309. See pp. 210, 222-223 above. 
or more who keep the commandments" in order to refute the devil's charge that Christ was a special case, and that no one can keep the law. ${ }^{177}$ Thus Andreasen draws in clear, stark lines what he sees as the culmination of the great controversy.

Other writers also see a future vindication of God, but generally do not link an end-time vindication of God's law with the question of whether believers are able to render perfect obedience, as does Andreasen. For instance, as early as the $1850 \mathrm{~s} \mathrm{~J} . \mathrm{H}$. Waggoner expected God to "vindicate the honor of his holy law" in the time of trouble; Uriah Smith similarly wrote of a time coming "when God will arise to vindicate the honor of his own name and law" by the outpouring of the last plagues. ${ }^{178}$ Again, J. H. Waggoner looked forward to the millennial review of the records of the unsaved as a time when God's government would be vindicated. ${ }^{179}$

However, corroboration of Andreasen's view of an end-time vindication of God by the obedient lives of His subjects can be found. In 1869 R. F. Cottrell spoke of an end-time "testing message" designed to "vindicate [God's] holy law," which would "exhibit ... such a people as the world has not seen since the dark ages." ${ }^{180}$ In the 1890 s Uriah Smith, speaking once more of an end-time vindication of God, made it clear that in the time of the end "is to be decided the great controversy.... Shall God or Satan ... be

${ }^{177}$ Ibid., 316. See pp. 212-213 above.

${ }^{178}$ J. H. Waggoner, "The Law of God," 154; U. Smith, "The Seven Last Plagues," 52. See pp. 109, 100-101 above.

${ }^{179}$ See p. 113 above.

${ }^{180}$ Cottrell, "The Closing Message - No. 19,” 205. See pp. 104-105 above. 
vindicated, and triumph at last?"181 And the issue for Smith seems to be the same as for Andreasen: The government of God is accused of being unjust "in laying upon men laws which they cannot keep." Furthermore, the overcoming of end-time believers is seen by Smith to be instrumental in vindicating God's government: Christ's sinless life "manifested here in our nature vindicates the government of God, and clears his throne" of the charge of condemning humans for not meeting impossible requirements. ${ }^{182}$ Smith thus agrees with Andreasen on a role for the last generation in vindicating God by their sinless living, even if he does not portray God as taking a risk and placing the outcome of the controversy in the hands of believers. For this stance, the writings of E. J. Waggoner and W. W. Prescott may serve as antecedents.

\section{God's Dependence on Witnesses}

One of the most unique aspects of Andreasen's view is that God is dependent on humans for a successful outcome of the cosmic controversy between good and evil. This belief is based on the idea that God has placed His government on trial in response to the challenges Satan has made, allowing His creatures to determine for themselves the fairness of His rule. Accordingly, Andreasen sees the last generation of believers as a critical element in God's trial, witnesses that God intends to bring forth, resting His case "on the weight of testimony adduced."

But even these more unique perspectives of Andreasen can be seen in the

\footnotetext{
${ }^{181}$ U. Smith, America's Crisis, 30-31. See pp. 176-177 above.

${ }^{182}$ U. Smith, Looking Unto Jesus, 36, 29. See pp. 177-178 above.

${ }^{183}$ Andreasen, The Sanctuary Service, 315. See p. 216 above.
} 
generation of Adventist leaders that preceded him. It was E. J. Waggoner who by 1899 had come to see the pre-Advent judgment as not a chance for "God to judge of the character of men, but to cause men to see the true character of God." ${ }^{184}$ Already in the early 1890s Waggoner had characterized the judgment as a forum for the universe to examine the evidence pertaining to Satan's charges regarding God's rule. ${ }^{185}$ And in spite of a number of denials in the early and mid-1890s that humans had anything to do with "giving Christ His kingdom," by his 1897 General Conference session message on "Witnesses for God," Waggoner was saying that God had "left the vindication of his character to his children. He has, as it were, risked his character with men.” That Waggoner's idea was not perceived at the time as speculative or maverick is seen in the report of how the listening delegates were moved to tears. ${ }^{186}$

Waggoner's portrayal of God, challenging His opposers to bring forth their witnesses, was taken up by I. H. Evans three years later in his Week of Prayer reading, "Ye Are My Witnesses." Here Evans uses Elijah, one "ripening for translation," and standing to vindicate God in the day of His trial before Israel, as a representative of the last generation, who "make manifest the patience of the saints" and "show what [God's] truth can do for those who receive it." ${ }^{, 187}$ Andreasen's last-generation theology clearly shares much with Evans's idea of end-time believers living translation-ready lives that

${ }^{184}$ E. J. Waggoner, "The Gospel of Isaiah,” 4. See p. 161 above.

${ }^{185}$ See pp. $160-161$ above.

${ }^{186}$ E. J. Waggoner, "The Authority of Christ," 231; idem, "Witnesses for God (General Conference Bulletin)," 55. See pp. 159, 161-162 above.

${ }^{187}$ I. H. Evans “'Ye Are My Witnesses',” 167. See pp. 174-175 above. 
serve to vindicate God in a time of crisis, and almost certainly is indebted to Waggoner's view of God leaving the vindication of His character to His end-time followers.

Andreasen's utilization of the story of Job, to form the basis of the idea that God uses human witnesses to answer Satan's challenges, finds a precedent in the 1895 Armadale camp meeting sermons of W. W. Prescott. Prescott clearly holds up Job as one who demonstrated to the onlooking universe "that there is a power in God's love sufficient to stand against trial."188 This is very close to Andreasen's "keeping power" motif. ${ }^{189}$ Prescott finds in Jas 5:11 ("Ye have heard of the patience of Job"), as does Andreasen, the biblical link between the last generation and the experience of Job. ${ }^{190}$ However, as noted above, Prescott does not give to the last generation the role of ultimate vindication of God's government, as does Andreasen. Rather, he points to the cross as the "climax" of the controversy. But then, just five paragraphs later, Prescott admonishes his hearers that "the controversy is in its height." 191 Therefore, Prescott and Andreasen, in their seeing two apparently contradictory climaxes, may be closer in their understanding than at first appears. After all, Andreasen also sees Satan's destiny fixed by Calvary, but with a chance to succeed again at the end. ${ }^{192}$

Related to Andreasen's picture of God's dependence on human witnesses is the

${ }^{188}$ Prescott, "The Kingdom of God [Concluded]," 60. See p. 188 above. For Andreasen's use of Job, see pp. 214-218 above.

${ }^{189}$ See pp. $224-227$ above.

${ }^{190}$ See pp. 189, 214-215 above.

${ }^{191}$ Prescott, "The Kingdom of God [Concluded]," 60. See pp. 188, 292 above.

${ }^{192}$ See pp. 210-211 above. 
confidence that God is said to have in His people. Just as Andreasen pointed out that God "was depending upon" Job, and that His "confidence in him was not misplaced," so Prescott declared that Job was "a man that could be trusted to reveal the power of God's love to hold him firm in his confidence." ${ }^{\prime 193}$ And E. J. Waggoner, writing in 1899 on "God's Witnesses," affirmed that God "has such confidence in man, ... that He is willing to risk His character with him." 194 Andreasen holds this concept so firmly that he makes the outcome of the conflict between good and evil dependent on the human witnesses, which leads him to ask the crucial, exhortative question, "Is [God's] confidence well placed?"195 Thus Andreasen takes to their logical conclusion concepts that had become prominent in Adventist thinking.

\section{The Final Demonstration Vindicates God}

The concepts of Waggoner and Andreasen are in close harmony at the point of understanding the significance of the final generation. Waggoner likely moved Adventist thinking into new territory with his understanding of the reason for the translation of believers in the end-time. This translation of the end-time saints, according to Waggoner, is not simply due to the fact that they come up to the end without "time to die." Rather,

"God is working out a marvelous plan for his own glory." ${ }^{196}$ As noted earlier, Waggoner

${ }^{193}$ Andreasen, "Patience of the Saints," 24; Prescott, "The Kingdom of God [Concluded]," 60. See pp. 216, 188 above.

${ }^{194}$ E. J. Waggoner, “God's Witnesses,” 339. See pp. 162-163 above.

${ }^{195}$ Andreasen, The Sanctuary Service, 320. See p. 217 above.

196 “Twelfth Meeting," 58. See p. 160 above. 
understood the heart of the pre-Advent judgment to be not an inspection of human character, but a revelation of God's character. He believed that the "only way in which [God] can demonstrate the perfection of his character, and take away his reproach, is in perfecting a people to his praise." ${ }^{\prime 197}$ This concept of God's end-time demonstration of His character in His followers as critical to God's vindication in the judgment most likely serves as the forerunner of Andreasen's views.

A key result of this end-time demonstration of Christ-like living is that no excuse for sin is seen to remain. This is the "most sweeping and conclusive demonstration of all the ages," except for "Christ's godly life," of what God can do in humans, Andreasen asserts. God thus demonstrates that "there is no excuse, and never has been any, for sinning."198 Likewise, E. J. Waggoner, in his 1893 article, "Witnesses for God," declares that "when we obey God, and when we exercise faith and claim His promised power to enable us to do His will, we testify that sin is without excuse; that God's government is just and right. ... This is that which we are to witness for God. What an honour to glorify Him by giving this testimony before men, before angels, and before all the beholding universe!"199

Other writers looked at in this study, including A. T. Jones, did not explicitly link the overcoming of sin by the final generation to the vindication of God. And Andreasen

${ }^{197}$ E. J. Waggoner, "Witnesses for God (General Conference Bulletin)," 57. See pp. 162, 296-297 above.

${ }^{198}$ Andreasen, The Sanctuary Service, 303, 318. See p. 222 above.

${ }^{199}$ E. J. Waggoner, "Witnesses for God (Present Truth)," 578. Cf. pp. 161-163 above. 
goes beyond even Waggoner in a number of aspects of his description of the final generation. When he writes that God needs to "produce at least one man who has kept the law," or else "Satan wins," Andreasen heightened the intensity of the final battle in a new way. And when Andreasen makes sweeping claims for the results of the victory of the last generation, that "it clears [God] of any and all charges which Satan has placed against Him," he goes beyond his predecessors. ${ }^{200}$ Whether this is a matter of a choice of words or expression, or whether Andreasen had a significantly new understanding of eschatological events, is not easy to determine. But the overall tenor of Andreasen's writing on the last generation, while it apparently draws heavily on the concepts of Ellen White, A. T. Jones, and E. J. Waggoner, and finds a number of antecedent threads in the writings of others, such as J. H. Waggoner, J. N. Andrews, Uriah Smith, and W. W. Prescott, stands apart in its emphatic portrayal of the divine predicament and the great responsibility resting on end-time believers for the success of the divine case in court.

\section{Summary and Conclusion}

\section{Summary}

It is clear from this comparative study that Andreasen's final-generation concepts are closely related to views held by Ellen White and other Adventists prior to 1937. When the writings of Ellen White and other Adventists are compared with Andreasen's understanding of the complete overcoming of sin by the final generation, a strong correlation is seen. But differences of emphasis also are seen. Ellen White, in her early writings, seems to focus more on the preparation needed by believers to stand through the

\footnotetext{
${ }^{200}$ Andreasen, The Sanctuary Service, 303-304, 316. See pp. 223-224, 219 above.
} 
time of trouble without an intercessor; they would need a protective covering to shield them during the time of trouble. Andreasen, when writing on the last generation, focuses instead on theodical concerns as of far more importance than believers' salvation. The saints' overcoming of sin enables God to win His case in court. And the time of trouble also serves as a security screening for the rest of the universe, since sinlessness alone is not enough to guarantee the future safety of the universe from the reintroduction of $\sin$.

Even if the motivation for overcoming seems somewhat different in Andreasen's and White's writings, the anticipated outcome appears to be identical. Both, in fact, make it clear that overcoming $\sin$ is a progressive work that reaches a climax that glorifies God at the end of history. All defects of character are seen to be eliminated, all thoughts and words come into harmony with God's will. The natural sinfulness of believers' natures is no longer expressed in their behavior. In fact, Andreasen understands forgiveness to result in a neutralization of the effects of sin, so that the believer stands in a similar condition to that of Adam before the fall. White also speaks of a restoration of a pre-Fall condition, but expresses this in terms of character perfection, by means of obedience. And Andreasen and White alike hold up Christ's life as a demonstration of the obedience that is possible for all believers to render.

When Andreasen's and White's views on sin and the sanctuary service are compared, a few interesting differences are seen. Andreasen places emphasis on the acquisition of hatred for sin as an eschatological development, an emphasis not seen in White's writings. More significant is Andreasen's interpretation of the sanctuary, in which he sees the blotting out of sin to be its complete eradication from believers' lives, contrary to White's tendency to view this as more a cleansing of the record based on prior 
confession of sin. And it seems to be quite significant that even when discussing the saints' trial during the time of trouble, White points to the need to have all sins previously confessed as the critical element. Andreasen's interpretation of the Holy Place ministry as relating to forgiveness and righteousness by faith, and the Most Holy Place as sanctification and the eradication of sin, is also different. White uses contexts other than the sanctuary service when speaking of the complete overcoming of sin.

Other Adventist writers tend to share with Andreasen and White an expectation of perfect overcoming on the part of believers. While some, as Uriah Smith and J. N. Andrews, seem to follow White in finding no difference between the level of obedience required across salvation history, others like D. T. Bourdeau and A. T. Jones are closer to Andreasen in seeing a unique attainment on the part of end-time believers. There are also differences in the way that the blotting out of sins is understood. Some, like J. N. Andrews, R. F. Cottrell, A. T. Jones, and Meade MacGuire, side with Andreasen's inclusion of sin's eradication from the life as a pre- or simultaneous condition, and others, like Smith, are closer to White's focus on confession and repentance as the proper preparation for the blotting out of sin. Similarly to Andreasen and White, writers like E. J. Waggoner and W. H. Branson, and also the leaders of the "holy flesh" movement, indicated they expected some type of restoration of the pre-Fall human condition (whether they meant the same thing by this or not). And W. W. Prescott, Jones, Waggoner, and Branson were seen as examples of those who, like Andreasen and White, understood Christ's life to demonstrate what is possible for believers.

Less correspondence was found between the views of Andreasen and other Adventists in regard to the issues of the challenge and vindication of God's government 
in the cosmic conflict between good and evil. When writing about Satan's charges regarding God's law, Ellen White and other Adventist writers typically include more than the charge that the law is impossible to obey, whereas Andreasen focuses almost entirely on this. Even during the time of trouble, White has Satan questioning the justice of forgiving "saints" whom the devil describes as not much different from himself. But even as to the charge that God is harsh in requiring the impossible, White points to Christ in His life as vindicating the law's justice and providing the needed evidence regarding the reasonableness of the law.

Both White and Andreasen refer to questions that were not answered at the cross. However, in explaining how the devil has a second chance to succeed in the conflict with God, Andreasen has to take a rather literal approach to understanding White's reference to Satan's triumph in the case that he should annihilate the saints at the end. When it comes to describing the experience of the saints during the time of trouble, White describes a group that seems to be in need of further improvement, with Satan's attacks targeting their confidence in God. Though White elsewhere notes the glory that the perfection of end-time saints will give to God, when writing on the time of trouble, she does not speak of this.

Andreasen's linkage of the character perfection of end-time believers and the vindication of God, though absent, or latent, in White's writings, is easier to detect in other writers. In the writing of other writers, three issues addressed in connection with vindication of God were identified: (1) the law's immutability; (2) God's justice in requiring obedience; and (3) God's justice in forgiving sinners. Andreasen speaks almost exclusively to the second issue raised. Andreasen, White, and Uriah Smith provide 
evidence that Christ's life answered this problem. But R. F. Cottrell, Uriah Smith, E. J. Waggoner, and W. W. Prescott also point out the role of the last generation in God's vindication. Prescott's use of Job as an example of a witness for God may have prepared the way for Andreasen's understanding of God's use of witnesses for vindication. Waggoner almost certainly laid the foundation for Andreasen's view that God is on trial in the pre-Advent judgment, and depends on the witness of His saints for His acquittal. But even Waggoner does not draw the lines as sharply as does Andreasen.

\section{Conclusion}

From this comparative study, it seems reasonable to conclude that Andreasen bases his understanding of the urgency of overcoming sin on the writings of Jones, Waggoner, and Prescott. Threads of "last-generation theology" are seen in many different writings over the history of the Adventist movement, but in the post-1888 period a distinct trend is seen toward recognizing a theodical significance for the Day of Atonement and the end-time judgment.

On the question of character perfection as manifested in the lives of end-time believers, there is general agreement among the writers examined, though here there are also indications of reservations on the part of some. Even Ellen White, who, throughout her writing career, tenaciously adhered to the need for perfect obedience as a preparation for the future life, does not provide explicit links between the end-time character perfection of the saints and God's name being cleared of the charges brought by Satan. Andreasen, then, represents one view of eschatology within Adventism that was particularly strong after the 1888 General Conference. It did not belong to the fringes of 
Adventism in the early twentieth century; it may have been the leading view at the time Andreasen published The Sanctuary Service. Andreasen's contribution, though, was to take these new concepts in Adventist thought, that had arisen slowly at first, and then swelled rapidly around the dawn of the twentieth century, and carry them to, what surely seemed to him, their logical conclusion. The result was a fully developed theology of a final generation that virtually replicates Christ's victory over sin, by which demonstration God gives proof of the falsity of the charges raised against Him. 


\section{CHAPTER 6}

\section{SUMMARY AND CONCLUSIONS}

\section{Summary}

This study attempted to analyze the final-generation theology of M. L. Andreasen by comparing his views with those of Adventist writers that preceded him. The purpose was to determine the Adventist roots of Andreasen's thought, and the relationship between his ideas and those of other, prior, writers. After an introductory chapter laid out the background and methods of the study, chapter 2 surveyed views related to Andreasen's concepts in the writings of Adventist writers up to the time of the 1888 General Conference session. Chapter 3 traced the rise of final-generation concepts in the years after 1888, up to the time of Ellen White's death in 1915. Chapter 4 examined evidence for last-generation concepts from 1915 through 1937, the year that Andreasen published The Sanctuary Service, and also included evidence from Andreasen's later works that dealt with the subject. Chapter 5 discussed similarities and differences between the views examined in chapters 2-4. This final chapter summarizes the key findings of the study, and then draws some general conclusions, and makes some suggestions for further study.

Chapter 2 revealed a foundation for Andreasen's focus on the final generation in the Crosier-Edson-Hahn view of an antitypical Day of Atonement two thousand years 
after Calvary. Careful distinctions by these early Adventists between what is to occur in the Holy Place and Most Holy Place ministries of the antitypical heavenly sanctuary led to an interest in the blotting out of sins that took place at the end of the Jewish year. Attention was thus given to the significance of an end-time atonement and the need for cleansing of worshipers, as well as sanctuary. Joseph Bates, architect of Adventist theology, quickly followed this trail, attempting to discover the chain of events that would take place prior to the Advent. He placed emphasis on the formation of a holy, cleansed people at the finishing of the atonement, and linked this with his discovery of the seventhday Sabbath, which created a natural platform for the emphasis of obedience to the law on the part of God's end-time saints. Bates envisioned a time of testing in which God would determine the willingness of professed followers to obey His law, even under difficult circumstances, while purifying them for their new home. Bates proclaimed the need for a sealing of the saints, as the preparation needed for the time of trouble to come.

Ellen White took this emphasis on the needed preparation for Christ's coming, and added some new concepts. In 1849 she pointed out that when Christ finished His work in the Most Holy Place, Christ would no longer intercede for sinners, and that a great battle would be fought between the forces of good and evil. During the 1850s White stressed the need for complete victory over sin, purity of heart and life, and a perfect reflection of Christ's image in order for believers to be prepared for translation. This study noted with interest that White emphasized the sealing of believers, just before the close of probation, as placing them beyond Satan's power, so that assumedly it would be impossible for them to fall after probation's close. In White's first edition of the Great Controversy, published in 1858, she developed more fully the concept of believers living 
through the time of trouble without an intercessor in the sanctuary above, at the same time introducing the severity of the mental struggle the last generation undergoes. In subsequent years she elaborated on the process of purification believers needed to undergo in preparation for the end, a process that ended when believers obtained the victory over all character defects. With the publication of the third volume of Spiritual Gifts in 1864, White began to strongly emphasize the need for confession of secret sins before probation closes, in connection with the story of Jacob wrestling with the angel. This study also carefully noted that around 1870 Ellen White made statements that showed she understood character perfection to be a requirement for being resurrected to eternal life, no less than for being translated without seeing death. In the same period, she began using the word "vindication" for what Christ accomplished in His life and death, with reference to God's law.

The years 1884-1888 were seen to be particularly productive, beginning with a greatly expanded commentary on last-day events, volume 4 of The Spirit of Prophecy, and ending with the publication of the 1888 edition of the same book, which became known as The Great Controversy. In her 1884 treatment of end-time events, she makes calls for perfection of character and confession of sin that seem stronger even than before. In describing the experience of the saints during the time of trouble, she portrays Satan accentuating their unworthiness, with God permitting him to try their confidence in Him. A new element is introduced here, when the saints are seen to be most troubled by the effect a failure on their part would have on the honor of God.

A significant development in the mid-1880s was White's use of the Zech 3:1-5 account of the high priest Joshua and the change of his garments. In this story White 
highlights the behind-the-scenes struggle between good and evil, pointing out the devil's accusations against those who try to obey God. Satan is seen accusing God of injustice if He saves end-time believers with less-than-perfect records, while He destroys him, the devil.

In comparing White's 1888 Great Controversy with the 1884 version, it was observed that in the 1888 version she expanded on a couple of themes in her earlier version. In her 1888 conclusion to the chapter "The Origin of Evil," White clarified her 1884 comments on how the cross vindicated the law, changing the expression to one of proving the law's immutability. And new language of vindication is inserted in connection with new paragraphs on the executive judgment, as well as in a new section on the outpouring of the seven last plagues. And, significantly for the question of whether sin is completely overcome by the last generation, she adds new language that links Christ's experience of separation from sin to the experience of those who endure the time of trouble.

Other pre-1888 Adventist writers examined, who expressed views relevant to those of Andreasen, were J. N. Andrews, Uriah Smith, R. F. Cottrell, and J. H. Waggoner. In 1869 Andrews pointed out that Christ would not be needed as priest after the sins of end-time believers were blotted out. As a requirement for those wishing to have their sins blotted out, He added perfect overcoming to full repentance, while warning against partial overcoming. Uriah Smith spoke of a special preparation needed for translation, while he maintained at the same time that there was no difference in the moral standard used in the judgment of the righteous living and dead. Cottrell, in speaking of the final generation in 1869 , used language in one instance that sounds much like Andreasen, pointing out the 
vindication of God's law as one of the objects of the third angel's message, a message that results in a manner of people the world has not seen since the dark ages. And J. H. Waggoner in the 1860s emphasized the need for God's vindication in the cosmic conflict, depicting in clear lines the dilemma created by Lucifer's false charges.

Chapter 3 dealt with the period 1888-1915. The writings of Ellen White that were examined showed no retreat from the high standards of character perfection called for earlier, though giving new attention to imputed righteousness. She rejected alike claims of sinlessness and denials of the attainability of complete overcoming. She continued to use the story of Joshua's change of garments, it becoming clear that she understood the change of garments, with reference to the final generation, to take place before the close of probation, when a Mediator was in place to defend believers from Satan's accusations.

During this period, White held up Christ's life as conclusive proof that the law was not impossible to keep. And while she did not directly use the language of vindication when she spoke of the perfection of character needed for the final generation, she did, however, point out that God's character would be clearly demonstrated by the final generation, and that the reflection of Christ's image by the end-time church would honor God. When White does present the experience of those undergoing the time of trouble, she mentions their allegiance to God as the quality that serves to vindicate God's law.

On examining A. T. Jones and E. J. Waggoner, the proponents of righteousness by faith at the 1888 General Conference session, new insights that are very relevant to a discussion of final-generation theology were noted. Jones held that Christ demonstrated a sinless life lived in sinful flesh, and that this was to be replicated in the final generation. 
This study also took note of Jones's strong views on the relationship between the endtime perfection of the saints and the cleansing of the sanctuary, based on the prophecy of Dan 9. Though Jones was observed to make Christ's coming dependent on the perfection of His people, in these instances he did not directly speak of their perfection as vindicating God.

Waggoner gave more attention to aspects of challenge and vindication. Though making some early statements regarding God's vindication being independent of humans, he later depicted God as on trial in the judgment, and needing the witness of His end-time followers for His vindication. Like Jones, Waggoner saw Christ's life as reproducible in His followers, by the indwelling of the Holy Spirit.

The proponents of the "holy flesh" movement believed that the last generation would experience a change of nature, acquiring the same sinless flesh they believed Christ to have had. In this way complete victory over sin would be attained.

Especially at the turn of the century a wave of calls for overcoming sin completely came to the Adventist church. John Brunson's sermon on the opening Sabbath of the 1899 General Conference session reminded delegates that sin must cease in God's followers before the Mediator finished His work. Other leaders similarly called for serious preparation for translation. I. H. Evans interestingly used the story of Elijah on Mount Carmel to combine the concepts of preparing for translation and God's use of witnesses to vindicate His honor. And even Uriah Smith, who at first opposed Jones's and Waggoner's emphasis on justification, in 1898 wrote that believers vindicated God's government when they lived Christ's sinless life.

Chapter 4 reviewed the developments from 1915-1937, followed by a delineation 
of the main aspects of Andreasen's understanding of the last generation. Three Adventist leaders in this period who were found to have significance for this study were A. G. Daniells, W. W. Prescott, and Meade MacGuire. Daniells strove to keep alive the 1888 focus on righteousness by faith, while passing over Waggoner's beliefs regarding the last generation vindicating God by replicating Christ's victorious life. Prescott, though, shared a belief in the possibility of believers gaining the victory over sin, just as Christ did. He stressed the indwelling of Christ as making possible a life of victory, like Enoch's. Earlier, in the 1890s, while preaching on the great controversy, Prescott had identified Job as a demonstration of the keeping power of God's love. MacGuire also wrote on victory over sin. Echoing Jones, he told delegates to the 1930 General Conference session that the cleansing of the sanctuary could not be finished as long as God's people continued to send up a stream of sins.

Also important in the years just prior to Andreasen's Sanctuary Service were the defections of two overseas administrators, Louis Conradi in Europe and W. W. Fletcher in Australia, both of whom took issue with the Adventist doctrine of the sanctuary. In response to these apostasies, General Conference President C. H. Watson and his successor-to-be, W. H. Branson, published books defending the Adventist positions. Though Watson identified having a clear conscience as the precondition for having one's sins blotted out, Branson stressed obedience over confession, while at the same time acknowledging the ability of Christ's righteousness to cover one's failures. Watson, Branson, and other leaders tended to address theodical concerns only by way of addressing criticisms of unique Adventist doctrines, such as the scapegoat.

M. L. Andreasen's biography was briefly noted. A Danish immigrant who was 
convinced of Adventist beliefs as a young man, Andreasen acquired knowledge of doctrinal problems in the Adventist church in his younger years, and eventually became one of the church's leading teachers. In 1937 he published The Sanctuary Service, the penultimate chapter of which details the importance of the last generation of believers in the controversy between good and evil.

Andreasen's last-generation theology was divided for the purpose of this study into two main components, which incorporated the six motifs suggested by Dwight Haynes. At the core of Andreasen's teaching was the idea that God is dependent on the final generation for vindication in His controversy with Satan. Satan's charge in the beginning, according to Andreasen, was that the law could not be kept, and God could not therefore justly punish transgressors. While he acknowledges that Christ proved Satan wrong, and made his eventual defeat certain, Andreasen suggests that the devil might have another chance if he can defeat God's followers. Satan is depicted dismissing, as special cases, Christ and even other humans in history who, according to Andreasen, have lived without sin for periods of time. In response, God is seen to produce an entire group of overcomers from the weakest generation that has lived, in order to give convincing proof of the fairness of His requirements. Andreasen shows how this group, like Job, undergoes severe testing, to exonerate God of the devil's false charges. Through their passing the test, God is cleared of all charges raised against Him.

Also examined was the related teaching of Andreasen that salvation is realized as complete victory over sin. In this view, the sanctuary services are seen to point the way toward the eradication of sin, and not merely its pardon. Andreasen interprets the bipartite service as focusing in the Holy Place on forgiveness and justification by faith, 
and then in the Most Holy Place on sanctification and the blotting out of sins from the life. Andreasen was seen to understand victory over sin not simply as a matter of changing behavior, but also as a redirection of affections, as end-time saints exhibit a hatred for sin. The final generation's victory over sin was seen by Andreasen to consist not only in cessation of sin, but enduring a stringent test of loyalty during the time of trouble, just as Adam and Christ, though sinless, needed to undergo testing to demonstrate their loyalty, or lack thereof.

In chapter 5, the views of Andreasen were compared with those of the other writers examined. The analysis first looked at how Andreasen compared with Ellen White and other writers on his understanding of the final generation's complete victory over sin. It was observed that Ellen White did not have Andreasen's theodical concerns when she began writing regarding the holiness required by the last generation. Her expressed concern was more for the survival of believers in the oncoming trouble, who are seen to need a covering for their protection. White began, though, gradually to turn attention more and more to larger issues at stake as she introduced and expanded her great controversy theme, including using the word (as well as the concept) "vindication" from the 1870 s.

Andreasen and White were seen to be very close in their views on the possibility of believers overcoming sin completely. Christ's life is taken by both writers to be a demonstration of how His followers can live. Likewise, they agree that some aspect of the pre-Fall condition will be restored, consequent to forgiveness, obedience, or both.

There was determined to be close agreement also on the nature of the law and its transgression, as speaking to thoughts and motives, and not just observable acts. 
However, differences were noted in the interpretation of the blotting out of sin, with White pointing to the confession of sin as the required precondition, while Andreasen emphasizes the cessation of sin. It was noted that although White speaks often of the need to overcome sin, confession and repentance are more often mentioned in connection with the blotting out of sin. A key finding in this section is White's identification of unconfessed sin as the primary threat to believers in the time of trouble, versus Andreasen's concern for the cessation of sin. The different foci of concern, and White's relatively unflattering description of the state of the final generation during the time of trouble, were noted by this study to convey a different message.

Significant findings were also seen when Andreasen was compared with other Adventist writers on the overcoming of sin. General agreement was observed regarding some special preparation needed by the last generation, even if perfect overcoming was seen to be a requirement for the saved of all generations, and not uniquely for the last generation. Throughout the period investigated, in regard to the general expectation of the perfect overcoming of sin by end-time saints, only a few hints of dissent were observed, most notably that of C. H. Watson in the 1930s.

There was observed less agreement on the preconditions for, and the meaning of, the blotting out of sin. J. N. Andrews seemed to early emphasize complete overcoming as a precondition, while Uriah Smith was seen to be ambiguous in his statements. Later, A. T. Jones laid the foundation more firmly for Andreasen when he identified the cessation of sin as the primary precondition for the blotting out of sin. But in the 1930s Walter Read and C. H. Watson were observed to identify confession and repentance as preconditions, without reference to sin's cessation. 
Along with Andreasen and White, E. J. Waggoner, John Brunson, W. H. Branson, and the "holy flesh" movement's leaders were observed to expect a restoration of some aspect of the pre-Fall human condition. And Prescott, Jones, Waggoner, and Branson gave evidence of an understanding similar to Andreasen's in relation to the victory made possible through Christ indwelling human flesh.

Less agreement was found with regard to the second category, challenge and vindication. Andreasen was found to follow White in addressing the origin of the controversy between good and evil in connection with interpreting last-day events. One difference that was seen was Andreasen's nearly exclusive focus on one of the two charges that White identifies, that God is harsh in requiring obedience to a severe law. In connection with end-time events, White, on the other hand, appeared to give just as much, if not more, attention to the second charge, that God is overly lenient in pardoning transgressors. Although both White and Andreasen were observed to recognize Christ's role in demonstrating the observability of the law, White was seen to give much more weight to Christ as Vindicator.

White and Andreasen were both shown to point out continuing unanswered questions after the cross, but Andreasen was seen to paint a much more definitive portrayal of the issues at stake. White's choice of biblical figures that correspond to the final generation-Joshua the high priest and Jacob, and even Enoch—were seen to give a different picture than does Andreasen's choice of Job, on which he bases his definite endtime scenario. Though White also uses Job as an example of the character witness God makes use of in the great controversy, she does not refer to Job when discussing the lastday trial of the saints. And in their portrayals of the struggles of the final generation 
during the time of trouble, White was observed to focus more on the perseverance of the believers' faith, while Andreasen focused more on obedience. In regard to the vindication of God, White was not found to link this directly to the final generation's overcoming of sin, as Andreasen strongly does. Rather she speaks of vindication more in contexts such as the outpouring of the last plagues, or the post-millennial executive judgment.

Variable correspondence was observed between Andreasen and other Adventist writers on the issue of vindication. Most of the other writers examined appeared to give Christ a greater role than did Andreasen, whether vindicating the law in His teaching, living, or dying. As to pointing out how Christ's life vindicated the fairness of the law's requirements, Uriah Smith clearly joins Andreasen in this regard. Cottrell and Smith were observed to agree with Andreasen in regard to an end-time vindication of God on the basis of the victorious lives of His followers, while other writers followed White in looking to the last plagues or the millennial review for an end-time vindication of God.

E. J. Waggoner, I. H. Evans, and W. W. Prescott were observed to share with Andreasen the view that God makes use of the witness of believers for victory in the great controversy. Prescott was seen to first utilize the story of Job to show God's dependence on witnesses in the context of the great controversy. However, he differed from Andreasen in going on to focus on the cross as the climax of the controversy, even though he seemed to also view the end-time as another climax. Waggoner appeared to be the closest to Andreasen, in depicting God as placing the outcome of the controversy in the hands of His followers, by whose overcoming all excuse for sin vanishes. 


\section{Conclusions}

From this study, a number of conclusions can be drawn. The most important finding is that Andreasen's theology of the final generation is based on a number of concepts found in the writings of Ellen White and other Adventist writers who preceded him. He is not the inventor of the idea that God's end-time people, faced with severe pressure to give up their faith, will refrain from sin. This is a nearly universally held view of Adventists throughout their short history. He is also not the inventor of the great controversy motif in Adventism, in which Satan is understood to have challenged the justice of God, which has led to a demonstration of the principles of good and evil in earth's history. This is also a universally held teaching in Adventism from the 1850s and 1860s. Andreasen is not even the inventor of the notion that end-time believers serve to vindicate God in His battle with evil. This was clearly taught by E. J. Waggoner at the close of the nineteenth century, as well as by W. W. Prescott, Uriah Smith, and I. H. Evans, who themselves built on the foundation laid by J. H. Waggoner. Andreasen likewise was not the first Adventist to speak of a termination of the sanctuary service in heaven as a result of its no longer being needed. J. N. Andrews had this understanding in the 1860 s, followed later by A. T. Jones and Meade MacGuire. Andreasen was not even the first to put the spotlight on Job in the context of God's need for vindication in the great controversy. W. W. Prescott had done this in the 1890 s, followed soon after, though less directly, by Ellen White.

A second important conclusion of this study is that Andreasen did not merely reiterate what others had said before. Andreasen took these eschatological strands and wove a tightly constructed scenario of end-time events, with precisely stated conditions, 
contingencies, and outcomes. Whether one agrees with his concepts or not, Andreasen's clear expressions at least provide a basis for meaningful debate. His version of finalgeneration theology is more developed than any of his predecessors, even if they might not have agreed with all of his conclusions. Andreasen, then, did not originate finalgeneration theology; rather, he defined it.

A third significant finding of this study is that Andreasen's key concepts find less support in the writings of Ellen White than in the writings of others, especially E. J. Waggoner, A. T. Jones, and W. W. Prescott. Though Ellen White was very clear on the need and expectation of complete overcoming of sin on the part of those preparing for translation, as well as the need to deal with the remaining questions in the ongoing controversy between good and evil, she did not directly link these two points, even when it would have been natural for her to do so, if she had been of Andreasen's persuasion.

However, this lack of direct correlation between Andreasen and White could be easily misinterpreted by Adventists, who hold White to have possessed the prophetic gift. Though this study has not had as one of its purposes the comparison of the writings of Ellen White and other Adventist writers (other than Andreasen), it has been observed here that over the course of White's career she was not typically the first to put forward new concepts. Rather, she would incorporate the findings of others into her writings, whether Bates's linking of the law and the Most Holy Place, J. H. Waggoner's concepts of atonement and vindication, the 1888-era emphasis on imputed righteousness and justification, or even W. W. Prescott's highlighting of Job as a witness for God in the great controversy. Thus, one would not expect to find the same degree of correlation between White's writings and the newly defined concepts of Andreasen, as between the 
writings of White and others who introduced new points during her lifetime.

What is more significant, therefore, than differences of emphases or tone, are ideas that are incompatible, or mutually exclusive. For example, it was observed that Andreasen, in describing the last generation's struggles, focuses on their avoidance of sin, while White seems more concerned with faith and allegiance. This difference of emphasis or expression would probably be misinterpreted if it were perceived to signal an underlying incompatibility of views. What this study has revealed is that White did not seem to have exactly the same focus as did Andreasen when writing on the last generation. There could be many reasons for this; the simplest possibility would be that she simply never thought about last-day events in the way Andreasen later did.

This is pointed out here to prevent the misapplication of this study. Since Adventists hold White to have possessed the gift of prophecy, it is easy to bring an end to a discussion by referring to statements that White made, even though isolated statements can easily give an incorrect impression of her thought. Beyond this danger is the problem that has been with the Christian church from the beginning — how to deal with new and unfamiliar teachings. The early church, faced with multiplying heresies, opted to strengthen the relative weight of apostolic tradition. It was a simple and effective strategy. If truth is progressive, though, this strategy can have a very limiting effect on that progress. It is this limiting effect that is being addressed here, in connection with a potential misuse of this study's arrangement of the evidence, whether it is found to be in favor of Andreasen's view, or opposed.

At this point it is probably helpful to reiterate that the purpose of this study was to analyze Andreasen's last-generation views as to their heredity, not their validity. Of 
course, the heredity of an idea is an important element to consider when evaluating that idea's validity. But it is only one step, even if often the most telling one. A full analysis of Andreasen's final-generation concepts would most likely make use of the insights of systematic theology and biblical studies, at a minimum.

\section{Suggestions for Further Study}

In the process of this examination of Adventist writers and final-generation theology, some questions have arisen that invite further study. In connection with a review of the 1930s sanctuary discussions, it was noted that theodical concerns were addressed often by way of defending the Adventist sanctuary doctrine from attack, the most striking example being the Adventist teaching on the scapegoat ritual. Efforts were made to show that when Adventists identify the scapegoat with the devil, they do not thereby make of him another savior. A clear argument brought forward in support of this denial is that the scapegoat comes into view only after the atonement has been made for sanctuary and congregation, all having been purified by the blood of the Lord's goat. This separation of the scapegoat from the rest of the service suggests that there is a builtin purely theodical component to the Day of Atonement, quite separate from the salvific, atoning components. From a human-salvation perspective, the scapegoat seems superfluous. But from a divine-vindication point of view, it is critical to show that God is not to blame. This Adventist anomaly in regard to sanctuary doctrine may find a parallel in Adventist views of eschatology, in which the most severe testing undergone by endtime saints occurs after they have passed under the scrutiny of the pre-Advent judgment, after they have been sealed and their eternal destiny fixed. This suggests that the post- 
probationary time of trouble in the Adventist eschatological sequence is related to theodical concerns, and not soteriological ones. Adventists have pointed out the connection between the Day of Atonement services in the sanctuary and the pre-Advent judgment. They have also seen the relationship between Satan's binding during the millennium and the scapegoat's wandering in the wilderness. But just as striking a parallel may be drawn between the scapegoat ritual and the post-probationary time of trouble, which according to Andreasen conclusively lays the blame for sin on the devil. This possible missing link in Adventist eschatology deserves further study.

Another question that may need more attention is an apparent parallel contradiction between the writings of Adventists in two areas. One is regarding the preconditions for the antitypical blotting out of sins. The other is the striking differences in the characterization of the experience of believers undergoing the time of trouble. It is intriguing that a number of writers, including Andreasen, strongly link the overcoming of sin to the blotting out of sin, while Ellen White stands at the head of another group that points to confession and deep repentance as the prime factor related to the end-time blotting out of sin. Similarly, Andreasen describes the saints during the time of trouble as being tested as to their unswerving obedience, while White characterizes the test as being over the maintenance of their wavering faith under trial. This contradiction may be more apparent than real, though. Andreasen himself recognized that sinless innocence was not enough for Lucifer, nor for Adam or Christ—-further testing revealed large differences. Thus Andreasen emphasized hatred of sin as necessary, beyond cessation of sin. Further study may be needed in order to appreciate the possibility, or impossibility, of harmonizing these two seemingly contradictory foci-the behavioral aspects of the test 
(cessation of sin, obedience), and issues of the heart (hatred of sin, repentance).

A related question is Andreasen's understanding of the nature of sin. While others have pointed out the behavioral slant in Andreasen's concept of sin, this study has recognized Andreasen's stress on the necessity of a hatred for sin as a possible indicator of a broader understanding of sin. Andreasen explains this concept in a way that shows he understands sin to lie at a much deeper level than observable phenomena. Even if one ceases to do wrong acts, and does only good acts, Andreasen would not confuse this with complete victory over sin, as long as one had a lingering desire for the sinful behavior. In other words, a propensity toward sin could constitute sin, in a revised Andreasenian hamartiology. Another look at the thinking behind Andreasen's rather unique emphasis on attaining a hatred for sin might be useful.

One further fruitful area of study may be the relationship between Andreasen's final-generation ideas and the corresponding concepts of A. T. Jones and E. J. Waggoner. While Andreasen appears to have made much use of the eschatological concepts of Jones and Waggoner, he appears to have had a different understanding of righteousness by faith. This becomes apparent in his associating righteousness by faith with the Holy Place ministry of the heavenly sanctuary, while the Most Holy Place ministry is linked to sanctification. Andreasen's concern that Adventists advance from justification to sanctification reveals what appears to be a quite different understanding of the role of justification by faith than that held by Jones and Waggoner in the post-1888 period. 


\section{BIBLIOGRAPHY}

Adams, Roy. The Nature of Christ: Help for a Church Divided over Perfection. Hagerstown, MD: Review and Herald, 1994.

. The Sanctuary: Understanding the Heart of Adventist Theology. Hagerstown, MD: Review and Herald, 1993.

. The Sanctuary Doctrine: Three Approaches in the Seventh-day Adventist

Church. Berrien Springs, MI: Andrews University Press, 1981.

Andreasen, M. L. The Book of Hebrews. Washington, DC: Review and Herald, 1948.

. "The Christian Life." Sabbath School Lesson Quarterly, no. 118. Mountain

View, CA: Pacific Press, 1924.

. The Faith of Jesus. Washington, DC: Review and Herald, 1949.

. The Faith of Jesus and the Commandments of God. Washington, DC: Review and Herald, 1939.

. A Faith to Live By. Washington, DC: Review and Herald, 1943.

. Isaiah, the Gospel Prophet, a Preacher of Righteousness. 3 vols. Washington, DC: Review and Herald, 1928.

. "Morning Bible Study: The Keeping Power of God." Advent Review and

Sabbath Herald, June 18, 1936, 298-299.

. "Morning Devotional Study: Patience of the Saints; Commandments of God;

the Faith of Jesus." Advent Review and Sabbath Herald, June 9, 1926, 23-26.

. Prayer. Mountain View, CA: Pacific Press, 1957.

. The Sabbath: Which Day and Why? Washington, DC: Review and Herald, 1942. Reprint, paperback ed., 1969.

. The Sanctuary Service. Takoma Park, Washington, DC: Review and Herald, 1937. 
Andreasen, M. L. The Sanctuary Service. 2d ed., rev. Washington, DC: Review and Herald, 1947.

. "The Spirit of Prophecy - Particularly the Account of Elder M.L. Andreasen's Personal Experience with Ellen White.” TMs (photocopy), [196-?]. Center for Adventist Research, James White Library, Andrews University, Berrien Springs, MI.

Andrews, John Nevins. The Judgment: Its Events and Their Order. Bible Students' Library, no. 55. Oakland, CA: Pacific Press, 1890. Reprint, Payson, AZ: Leavesof-Autumn Books, 1989.

. "The Order of Events in the Judgment - Number Five." Advent Review and Sabbath Herald, December 7, 1869, 188-189.

. "The Order of Events in the Judgment - Number One." Advent Review and Sabbath Herald, November 9, 1869, 156.

. "The Order of Events in the Judgment - Number Three." Advent Review and Sabbath Herald, November 23, 1869, 172.

. "Our Light and Our Responsibility." Advent Review and Sabbath Herald, August 29, 1865, 100.

. The Perpetuity of the Royal Law: Or, the Ten Commandments Not Abolished. Rochester, NY: Advent Review Office, 1854.

. Review of the Remarks of O. R. L. Crozier, on the Institution, Design and Abolition of the Sabbath. Rochester, NY: Advent Review Office, 1853.

. Sermons on the Sabbath and Law: Embracing an Outline of the Biblical and Secular History of the Sabbath for Six Thousand Years. 2d ed. Battle Creek, MI: Steam Press of the Seventh-day Adventist Publishing Association, 1870.

. "The Three Angels of Rev. XIV, 6-12." Advent Review and Sabbath Herald, April 17, 1855, 209-212.

. The Three Messages of Revelation XIV, 6-12, Particularly the Third Angel's Message, and Two-Horned Beast. 5th, rev. ed. Battle Creek, MI: Review and Herald Pub. Co., 1892. Reprint, Brushton, NY: TEACH Services, 1998. 
Bates, Joseph. The Opening Heavens: Or a Connected View of the Testimony of the Prophets and Apostles, Concerning the Opening Heavens Compared with Astronomical Observations: And of the Present and Future Location of the New Jerusalem, the Paradise of God. New Bedford, [MA]: Press of Benjamin Lindsey, 1846. Reprint, as pp. 1-39 of Bates' Pamphlets, Payson, AZ: Leaves-of-Autumn Books, 1987.

. A Seal of the Living God. A Hundred Forty-Four Thousand, of the Servants of God Being Sealed, in 1849. New Bedford, MA: Press of Benjamin Lindsey, 1849. Reprint, as pp. 1-72 of Joseph Bates et al., Early S.D.A. Pamphlets, Payson, AZ: Leaves-of-Autumn Books, 1987.

. Second Advent Way Marks and High Heaps: Or a Connected View of the Fulfilment of Prophecy, by God's Peculiar People, from the Year 1840-1847. New Bedford, MA: Press of Benjamin Lindsey, 1847. Reprint, as pp. 41-122 of Bates’ Pamphlets, Payson, AZ: Leaves-of-Autumn Books, 1987.

. The Seventh Day Sabbath: A Perpetual Sign from the Beginning to the Entering into the Gates of the Holy City According to the Commandment. 2d. rev. and enl. ed. New Bedford: Benjamin Lindsey, 1847. Reprint, as pp. 51-115 of The Sabbath Controversy, Payson, AZ: Leaves-of-Autumn Books, 1987.

. A Vindication of the Seventh-day Sabbath and the Commandments of God: With a Further History of God's Peculiar People from 1847-1848. New Bedford, MA: Press of Benjamin Lindsey, 1848. Reprint, as pp. 117-234 of The Sabbath Controversy, Payson, AZ: Leaves-of-Autumn Books, 1987.

Bates, P. M. Extract of letter to the editor. Advent Review and Sabbath Herald, December $23,1851,72$.

Bourdeau, Daniel T. "Advances of God's People under the Messages, and the Dangers of Backsliding." Advent Review and Sabbath Herald, February 19, 1867, 121-122.

. "Refutation of Instantaneous Sanctification." Advent Review and Sabbath Herald, November 27, 1879, 169-170.

. "Report from California." Advent Review and Sabbath Herald, February 23, $1869,69$.

. Sanctification; or, Living Holiness. Battle Creek, MI: Steam Press, 1864. Reprint, Nashville: Southern, 1970.

Branson, William H. The Atonement in the Light of God's Sanctuaries. Mountain View, CA: Pacific Press, 1935. 
Branson, William H. "Christ's Ministry in the First Apartment of the Heavenly Sanctuary." Signs of the Times, August 14, 1934, 3, 14-15.

. "The Cleansing of the Earthly Sanctuary." Signs of the Times, August 21, 1934, 3, 12.

. "The Cleansing of the Heavenly Sanctuary." Signs of the Times, August 28, 1934, 3, 15.

. In Defense of the Faith: The Truth About Seventh-day Adventists: A Reply to Canright. Takoma Park, Washington, DC: Review and Herald, 1933.

. "The Sanctuaries of God." Signs of the Times, July 24, 1934, 3, 7.

. "The Scapegoat." Watchman, February 1929, 25.

. "A Time of Cleansing and of Judgment." Signs of the Times, September 11, 1934, 4-5, 10.

Brunson, John A. "Preparation for Translation." Daily Bulletin of the General Conference, February 20, 1899, 39-40.

. "Prepare for Translation." General Conference Bulletin, Fourth Quarter 10, $1899,78-81$.

Dudley M. Canright. Seventh-day Adventism Renounced. New York: Fleming H. Revell, 1889.

Cottrell, Roswell F. "The Cleansing of the Sanctuary - No. 4." Advent Review and Sabbath Herald, April 1, 1884, 219.

. "The Closing Message - No. 19." Advent Review and Sabbath Herald, December 21, 1869, 205.

. "Holiness." Advent Review and Sabbath Herald, February 10, 1859, 92-93. 82 .

. "No Scolding." Advent Review and Sabbath Herald, March 8, 1860, 125.

. "Simplicity of Bible Truth." Advent Review and Sabbath Herald, May 12, 1853, 203-204.

Crosier, O. R. L. “The Law of Moses.” Day-Star Extra, February 7, 1846, 37-44. 
Damsteegt, P. Gerard. Foundations of the Seventh-day Adventist Message and Mission. Grand Rapids: Eerdmans, 1977.

Daniells, Arthur Grosvenor. Christ Our Righteousness: A Study of the Principles of Righteousness by Faith as Set Forth in the Word of God and the Writings of the Spirit of Prophecy. Washington, DC: Ministerial Association of Seventh-day Adventists, 1926.

. "The Ministerial Association." Advent Review and Sabbath Herald, June 6, $1930,122-125$.

, Los Angeles, CA, to W. W. Prescott, Berrien Springs, MI, December 6, 1934. Box 2, Folder 2, William Warren Prescott Papers (Collection 143). Center for Adventist Research, James White Library, Andrews University, Berrien Springs, MI.

Donnell, R. S. "The Nature of Christ and Man." An essay written in Memphis, TN, about the year 1900 and sent to S. S. Davis. Copy in the files of William H. Grotheer. Quoted in William H. Grotheer, The Holy Flesh Movement: 1899-1901. Florence, MS: Adventist Laymen's Foundation of Miss., 1973.

. "What I Taught in Indiana." [1907?]. Ellen G. White Estate Branch Office Document File 190, Center for Adventist Research, James White Library, Andrews University, Berrien Springs, MI.

Douglass, Herbert E. God at Risk: The Cost of Freedom in the Great Controversy between God and Satan. Roseville, CA: Amazing Facts, 2004.

Douglass, Herbert E., Edward Heppenstall, Hans K. LaRondelle, and C. Mervyn Maxwell. Perfection: The Impossible Possibility. Nashville: Southern, 1975.

Draper, G. W. "Holiness (Concluded)." Advent Review and Sabbath Herald, August 4, $1891,482$.

EGW Encyclopedia, forthcoming. S.v. "Bates, Prudence M. (Nye)."

"Eleventh Meeting, Tuesday, 9:30 A. M., February 21." Daily Bulletin of the General Conference, February 22, 1899, 51-53.

Evans, I. H. “'Ye Are My Witnesses'.” General Conference Bulletin, Third Quarter, 1900, 165-169. 
Evans, Paul M. “An Analysis of M. L. Andreasen's View of God's Vindication in Relation to the Writings of Ellen White." Term paper, Andrews University, 2002. Center for Adventist Research, James White Library, Andrews University, Berrien Springs, MI.

. "Seventh-day Adventist Views of the Sanctuary and the Atonement, 19201936." Term paper, Andrews University, 2004. Center for Adventist Research, James White Library, Andrews University, Berrien Springs, MI.

Froom, Le Roy Edwin. The Prophetic Faith of Our Fathers: The Historical Development of Prophetic Interpretation. 4 vols. Washington, DC: Review and Herald, 19461954.

Gane, Roy. Cult and Character: Purification Offerings, Day of Atonement, and Theodicy. Winona Lake, IN: Eisenbrauns, 2005.

General Conference of Seventh-day Adventists (Battle Creek, MI). Minutes of Meetings of the General Conference Committee, October 3-31, 1899.

Goldstein, Clifford R. “The Full and Final Display.” Ministry, October 1994, 41-43, 62.

Gordon, Adoniram Judson. The Ministry of the Spirit. Philadelphia: American Baptist Publication Society, 1894.

. The Ministry of the Spirit. Washington, DC: Review and Herald, 1950.

Griggs, Sarah. "From Sister Griggs." Advent Review and Sabbath Herald, February 3, $1852,87-88$.

Haddock, Robert. "A History of the Doctrine of the Sanctuary in the Advent Movement, 1800-1905.” B.D. thesis, Andrews University, 1970.

Hallman, Wesley. "A Biography of Milian Lauritz Andreasen During the Years 19351950.” Term paper, Andrews University, 1974.

Harmon, Ellen G. "Letter from Sister Harmon. Fulmouth, Mass., Feb., [sic] 15, 1846." Day-Star, March 14, 1846, 7; reprint, in Ellen G. White, Ellen G. White Periodical Resource Collection, comp. the Ellen G. White Estate. Boise, ID: Pacific Press, 1990.

. "Letter from Sister Harmon. Portland, Me., Dec. 20, 1845." Day-Star, January 24, 1846, 31-32; reprint, in Ellen G. White, Ellen G. White Periodical Resource Collection, comp. the Ellen G. White Estate. Boise, ID: Pacific Press, 1990.

. To the Little Remnant Scattered Abroad. Portland, ME, 1846. 
Haskell, Stephen Nelson. "The Spirit of Prophecy." General Conference Daily Bulletin, May 31, 1909, 227-229.

Haynes, Dwight Eric. "The Final Generation: A Descriptive Account of the Development of a Significant Aspect of M. L. Andreasen's Eschatology as Related to His Treatment of the Sanctuary Doctrine between 1924-1937." M.A. thesis, Andrews University, 1990.

Historical Sketches of the Foreign Missions of the Seventh-day Adventists: With Reports of the European Missionary Councils of 1883, 1884, and 1885, and a Narrative by Mrs. E. G. White of Her Visit and Labors in These Missions. Basle: Imprimerie Polyglotte, 1886. Reprint, George R. Knight, ed., Historical Sketches of Foreign Missions, with an introduction by George R. Knight, Adventist Classic Library, ed. George R. Knight. Berrien Springs, MI: Andrews University Press, 2005.

Holbrook, Frank B., ed. Doctrine of the Sanctuary: A Historical Survey (1845-1863). Silver Spring, MD: Biblical Research Institute, General Conference of Seventhday Adventists, 1989.

Holser, H. P. “God's Glory.” General Conference Daily Bulletin, February 17, 1897, 5355.

Hoopes, L. A. "Take Heed Lest Ye Fall.” General Conference Bulletin, Fourth Quarter, $1899,90-93$.

Irwin, George A. "The Last Call.” General Conference Bulletin, Fourth Quarter, 1899, 75-78.

. "The Third Angel's Message." Sermon of Sabbath, February 10, 1900, at the Tabernacle, Battle Creek, MI. General Conference Bulletin, First Quarter, 1900, 105-112.

Jankiewicz, Darius W. "The Doctrine of Sin within Its Soteriological Context in the Writings of M. L. Andreasen.” Term paper, Andrews University, 1996. Center for Adventist Research, James White Library, Andrews University, Berrien Springs, MI.

Jones, Alonzo Trevier. The Consecrated Way to Christian Perfection. Mountain View, CA: Pacific Press, 1905.

. "General Meeting in Indiana." General Conference Bulletin, Second Quarter, 1901, 511-512. . The Great Nations of to-Day. Battle Creek, MI: Review and Herald, 1901. 
Jones, Alonzo Trevier. “The Third Angel's Message, No. 15.” General Conference Bulletin, February 22, 1895, 298-304.

. "The Third Angel's Message, No. 19." General Conference Bulletin, February $27,1895,365-368$.

. "The Third Angel's Message, No. 20." General Conference Bulletin, February $27,1895,376-383$.

. "The Third Angel's Message, No. 23." General Conference Bulletin, March 4, 1895, 445-450.

. "The Third Angel's Message, No. 25." General Conference Bulletin, March 5, $1895,472-480$.

. "The Third Angel's Message - No. 10." Daily Bulletin of the General Conference, February 9-10, 1893, 200-208.

. "The Third Angel's Message - No. 17." Daily Bulletin of the General Conference, February 26, 1893, 399-406.

. "The Third Angel's Message - No. 18." Daily Bulletin of the General Conference, February 27, 1893, 409-417.

. "What It Means to Be a Church-Member." Sermon by Elder A. T. Jones, March 29, 3 P.M. General Conference Bulletin, April 1, 1903, 40-44.

[Jones, Alonzo Trevier]. "Fifth Righteousness Sermon at Ottawa, Kansas.” Topeka Daily Capital, May 18, 1889, 5.

Kiley, Jamie. "The Doctrine of Sin in the Thought of George R. Knight: Its Context and Implications.” M.A. thesis, Andrews University, 2009.

Knight, George R. Angry Saints: Tensions and Possibilities in the Adventist Struggle over Righteousness by Faith. Hagerstown, MD: Review and Herald, 1989.

. Joseph Bates: The Real Founder of Seventh-day Adventism. Hagerstown, MD: Review and Herald, 2004.

. Myths in Adventism. Hagerstown, MD: Review and Herald, 1985.

. A Search for Identity: The Development of Seventh-day Adventist Beliefs. Hagerstown, MD: Review and Herald, 2000. 
Litch, Josiah. Prophetic Expositions: Or, a Connected View of the Testimony of the Prophets Concerning the Kingdom of God and the Time of Its Establishment. Boston: Joshua V. Himes, 1842. Quoted in John Nevins Andrews. The Judgment: Its Events and Their Order. Bible Students' Library, no. 55. Oakland, CA: Pacific Press, 1890. Reprint, Payson, AZ: Leaves-of-Autumn Books, 1989.

MacGuire, Meade. "The Cleansing of the Sanctuary." Advent Review and Sabbath Herald, June 26, 1930, 7-9.

. His Cross and Mine. Takoma Park, Washington, DC: Review and Herald, 1927.

. The Life of Victory. Washington, DC: Review and Herald, 1924.

McGraw, Paul. "Born in Zion? The Margins of Fundamentalism and the Definition of Seventh-day Adventism." Ph.D. dissertation, The George Washington University, 2004.

Miller, William. Evidence from Scripture and History of the Second Coming of Christ About the Year 1843: Exhibited in a Course of Lectures. Boston: J. V. Himes, 1842. Reprint, Payson, AZ: Leaves of Autumn Books, 1988.

Moon, Jerry Allen. "M. L. Andreasen, L. E. Froom, and the Controversy over Questions on Doctrine." Term paper, Andrews University, 1988. Center for Adventist Research, James White Library, Andrews University, Berrien Springs, MI.

Moore, A. Leroy. Adventism in Conflict. Hagerstown, MD: Review and Herald, 1995. . Questions on Doctrine Revisited!: Keys to the Doctrine of Atonement and Exprience of At-one-ment. Ithaca, MI: AB Publishing, 2005.

. Theology in Crisis: Or, Ellen G. White's Concept of Righteousness by Faith as It Relates to Contemporary SDA Issues. Corpus Christi, TX: Life Seminars, 1980.

Nam, Juhyeok. "Reactions to the Seventh-day Adventist Evangelical Conferences and Questions on Doctrine, 1955-1971." Ph.D. dissertation, Andrews University, 2005.

“A Notable Day.” Daily Bulletin of the General Conference, February 19, 1899, 25.

Paxton, Geoffrey J. The Shaking of Adventism. Grand Rapids, MI: Baker, 1978. 
Perman, Kenneth. "A Biographical Sketch of M. L. Andreasen.” Term paper, Andrews University, 1974. Center for Adventist Research, James White Library, Andrews University, Berrien Springs, MI.

Porter, R. C. "The Mind of Christ - No. 5." Daily Bulletin of the General Conference, February 5, 1893, 144-147.

Prescott, William Warren. The Doctrine of Christ: A Series of Bible Studies for Use in Colleges and Seminaries. Washington, DC: Review and Herald, 1920.

. "The Faith of Jesus, the Commandments of God, and the Patience of the Saints [Concluded]." November 2, 1895, Armadale Camp Meeting Talk. Bible Echo, January 27, 1896, 28-29.

. "The Kingdom of God; or the Great Controversy between Good and Evil." October 23, 1895, Armadale Camp Meeting Talk. Bible Echo, February 17, 1896, 52-53.

. "The Kingdom of God; or the Great Controversy between Good and Evil [Concluded]." October 23, 1895, Armadale Camp Meeting Talk. Bible Echo, February 24, 1896, 60-61.

. "Modern Babylon Substitutes Paganism for Christianity (Continued from Dan. vii.)." Present Truth, June 14, 1900, 373-375.

. Victory in Christ: Ten Short Talks to Those Who Would Know the Joy of Freedom from Sin. Washington, DC: Review and Herald, 1924.

Read, Walter E. "Studies on the Sanctuary - No. 8: The Final Disposal of Sin." Advent Review and Sabbath Herald, October 20, 1932, 8-9.

. "Studies on the Sanctuary - No. 9: The Hour of Judgment." Advent Review and Sabbath Herald, October 27, 1932, 9-10.

Robinson, A. T. "Our Message." Advent Review and Sabbath Herald, July 20, 1905, 910.

"Sabbath Services." General Conference Daily Bulletin, March 8, 1897, 319-320.

Schwarz, Richard W. Light Bearers to the Remnant: Denominational History Textbook for Seventh-Day Adventist College Classes. Mountain View, CA: Pacific Press, 1979.

Seventh-day Adventist Encyclopedia. 2d rev. ed. (1996). 
Seventh-day Adventists Answer Questions on Doctrine. Annotated ed. With notes and historical and theological introduction by George R. Knight. Berrien Springs, MI: Andrews University Press, 2003.

Short, Donald K. "Then Shall the Sanctuary Be Cleansed." Paris, OH: Glad Tidings, 1991.

Shuler, John Lewis. The Great Judgment Day: In the Light of the Sanctuary Service. Washington, DC: Review and Herald, 1923.

Smith, Eliza. "From Sister Smith." Advent Review and Sabbath Herald, April 21, 1859, 175.

Smith, Uriah. America's Crisis. Oakland, CA: Pacific Press, 1895.

. Both Sides on the Sabbath and Law: Review of T. M. Preble. Battle Creek, MI: Steam Press of the Seventh-day Adventist Pub. Association, 1864.

. Daniel and the Revelation: The Response of History to the Voice of Prophecy, a Verse by Verse Study of These Important Books of the Bible. Nashville:

Southern Pub. Association, 1907.

. “[Editor's Note].” Advent Review and Sabbath Herald, July 29, 1862, 66.

." "If We Are Only Ready."” Advent Review and Sabbath Herald, November 10, 1859, 196.

. Looking Unto Jesus: Or, Christ in Type and Antitype. Chicago, IL: Review and Herald, 1898. Reprint, Payson, AZ: Leaves of Autumn Books, 1979.

. Man's Nature and Destiny: Or, the State of the Dead, the Reward of the Righteous, and the End of the Wicked. 3d ed., rev. and enl. Battle Creek, MI: Review and Herald, 1884.

. "The Seven Last Plagues." Advent Review and Sabbath Herald, June 18, $1857,52-53$.

. "The Wedding Garment." Advent Review and Sabbath Herald, April 2, 1861, 156-157.

"Special Winter Term of the Southern Industrial School." Advent Review and Sabbath Herald, December 26, 1899, 842 (14). 
Stagg, Arthur J. "The Doctrine of Atonement as Presented by M. L. Andreasen.” Term paper, Andrews University, 1995. Center for Adventist Research, James White Library, Andrews University, Berrien Springs, MI.

"Statement on Conradi Hearing. Hotel Rome, Omaha, Nebraska, Oct. 13-16, 1931." By committee appointed by the General Conference Committee to hear the views of L. R. Conradi; C. H. Watson, chairman. TD (photocopy). Center for Adventist Research, James White Library, Andrews University, Berrien Springs, MI.

Steinweg, Virginia. Without Fear or Favor: The Life of M. L. Andreasen. Washington, DC: Review and Herald, 1979.

Stephenson, J. M. "The Atonement (Continued)." Advent Review and Sabbath Herald, October 31, 1854, 89-91.

. "The Atonement (Continued)." Advent Review and Sabbath Herald, November 7, 1854, 97-100.

"Twelfth Meeting, Tuesday, 2:30 P. M., February 21." Daily Bulletin of the General Conference, February 23, 1899, 57-69.

Waggoner, Ellet Joseph. "The Authority of Christ." Present Truth, April 12, 1894, 227232.

. "The Blotting out of Sin." Advent Review and Sabbath Herald, September 30, $1902,8$.

. Christ and His Righteousness. Oakland, CA: Pacific Press, 1889.

. The Everlasting Covenant. [London]: International Tract Society, 1900.

. The Everlasting Covenant: God's Promises to Us. Berrien Springs, MI: Glad Tidings, 2002.

. "Front Page." Present Truth, August 30, 1894, 545.

. “God's Witnesses.” Present Truth, June 1, 1899, 339.

. "The Gospel of Isaiah: The Great Case at Law." Present Truth, January 5, $1899,2-5$.

. "Letter to the Romans - No. 3." Daily Bulletin of the General Conference, March 10, 1891, 63-64. 
Waggoner, Ellet Joseph. "Notes on the International Sunday School Lesson: The Captivity of Judah. Jeremiah 52:1-11." Present Truth, December 8, 1898, 770771.

. "Romans 3:9-12 (Concluded)." Signs of the Times, August 25, 1890, 457-458.

. "The Sanctuary of God." Present Truth, December 8, 1898, 771-774.

. "Sermon, April 6, 7 P.M." General Conference Bulletin, April 9, 1901, 145150.

. "Sermon, April 16, 7 P.M." General Conference Bulletin, April 22, 1901, $403-408$

. "Studies in Romans: The Sum of the Matter." Signs of the Times, January 9, 1896, 2-4 (18-20).

."Studies in the Book of Hebrews - No. 1 (Tuesday Afternoon, Feb. 9, 1897)." General Conference Daily Bulletin, February 12, 1897, 6-9.

. "Witnesses for God." Present Truth, December 14, 1893, 577-578.

. "Witnesses for God." General Conference Bulletin, First Quarter, 1897, 5457.

Waggoner, Joseph Harvey. "The Atonement - No. 12." Advent Review and Sabbath Herald, April 21, 1874, 150.

. The Atonement: An Examination of a Remedial System in the Light of Nature and Revelation. 3rd ed. Oakland, CA: Pacific Press, 1884. Reprint, as The Atonement in the Light of Nature and Revelation. Brushton, NY: TEACH Services, 1997.

. The Atonement: An Examination of a Remedial System, in the Light of Nature and Revelation. Battle Creek, MI: Steam Press of the Seventh-day Adventist Pub. Association, 1868.

. "The Law of God - No. 15: Dead to Sin." Advent Review and Sabbath Herald, June 24, 1875, 201-202.

. "The Law of God: An Examination of the Testimony in Both Testaments (Concluded)." Advent Review and Sabbath Herald, July 25, 1854, 193-196.

."The Law of God: An Examination of the Testimony in Both Testaments (Continued)." Advent Review and Sabbath Herald, November 22, 1853, 153-156. 
Waggoner, Joseph Harvey. "Meetings in Southern Iowa." Advent Review and Sabbath Herald, August 6, 1861, 76.

14.

."The Moral System." Advent Review and Sabbath Herald, June 9, 1863, 13-

. "The Nature and Tendency of Modern Spiritualism." Advent Review and Sabbath Herald, February 4, 1858, 97-99.

. "The Nature of the Sacrifice: The Son of God Died." Advent Review and Sabbath Herald, October 27, 1863, 173-174.

. "Present Truth." Advent Review and Sabbath Herald, August 7, 1866, 76-77.

. "Reason Not against an Atonement." Advent Review and Sabbath Herald, June 2, 1863, 1-2.

. "Who Changed the Sabbath? (Concluded)." Advent Review and Sabbath Herald, December 20, 1887, 793-795 (9-11).

Watson, Charles Henry. The Atoning Work of Christ: His Sacrifice and Priestly Ministry. Takoma Park, Washington, DC: Review and Herald, 1934.

. "The Cleansing of the Sanctuary." Advent Review and Sabbath Herald, March $14,1935,12-14$.

. "The Investigative Judgment." Advent Review and Sabbath Herald, March 7, 1935, 3-4.

. "The Most Holy Place.” Advent Review and Sabbath Herald, February 28, $1935,10-11$.

, Wahroonga, New South Wales, to Our Field Workers in the Australasian Division, TLS (photocopy), March 27, 1930. Fletcher et al., Correspondence, 1930-1946 on the sanctuary question and investigative judgment with E. S. Ballenger, L. R. Conradi, and others. Center for Adventist Research, James White Library, Andrews University, Berrien Springs, MI.

. "The Sanctuary in Heaven." Advent Review and Sabbath Herald, February 21, 1935, 4-5.

Weber, Martin. Who's Got the Truth? Making Sense out of Five Different Adventist Gospels. Silver Spring, MD: Home Study International Press, 1994. 
Webster, Eric Claude. Crosscurrents in Adventist Christology. New York: P. Lang, 1984. Reprint, Berrien Springs, MI: Andrews University Press, 1992.

Whidden, Woodrow W. E. J. Waggoner: From the Physician of Good News to the Agent of Division. Hagerstown, MD: Review and Herald, 2008.

. Ellen White on the Humanity of Christ: A Chronological Study. Hagerstown, MD: Review and Herald, 1997. $44-47$.

."The Vindication of God and the Harvest Principle." Ministry, October 1994,

Whitcomb, Rebekah. "From Sister Whitcomb." Advent Review and Sabbath Herald, December 23, 1851, 66-67.

White, Arthur L. Ellen G. White. 6 vols. Washington, DC: Review and Herald, 19811986.

White, Ellen G. “'Abide in Me.” Signs of the Times, March 23, 1888, 177-178 (1-2).

. "Accepted in Christ." Signs of the Times, July 4, 1892, 534 (6).

. "An Address to the Workers." Advent Review and Sabbath Herald, November 10, 1885, 689-691 (1-3).

. "Advancing in Christian Experience." MS 8, 1888. Minneapolis General Conference, Sabbath, October 20, 1888. Published in The Ellen G. White 1888 Materials. Washington, DC: E. G. White Estate, 1987.

. An Appeal to Mothers. Battle Creek, MI: Seventh-day Adventist Pub. Association, 1864.

. "Be Ye Therefore Perfect." MS 157, 1898. Published, in part, in Manuscript Releases: From the Files of the Letters and Manuscripts Written by Ellen G. White, 21 vols. Silver Spring, MD: E. G. White Estate, 1981-1993.

. “'Be Ye Therefore Perfect."” Signs of the Times, July 17, 1901, 3-4 (451-452).

, St. Helena, CA, to Brethren and Sisters, February 18, 1905. Letter 67, 1905. Published, in part, in Manuscript Releases: From the Files of the Letters and Manuscripts Written by Ellen G. White, 21 vols. Silver Spring, MD: E. G. White Estate, 1981-1993. 
White, Ellen G, to Brethren in Responsible Positions in the Review and Herald Office, January 13, 1894. Letter 70, 1894. Published, in part, in Manuscript Releases: From the Files of the Letters and Manuscripts Written by Ellen G. White, 21 vols. Silver Spring, MD: E. G. White Estate, 1981-1993.

, to Brother and Sister Dodge, December 21, 1851. Letter 9, 1851. Published, in part, in Manuscript Releases: From the Files of the Letters and Manuscripts Written by Ellen G. White, 21 vols. Silver Spring, MD: E. G. White Estate, 19811993.

, Oswego, NY, to Brother and Sister Hastings, [New Ipswich, NH], January 11, 1850. Letter 18, 1850. Published under the title "Better Days Are Coming" in Manuscript Releases: From the Files of the Letters and Manuscripts Written by Ellen G. White, 21 vols. Silver Spring, MD: E. G. White Estate, 1981-1993.

, to Brother Barnes, December 14, 1851. Letter 5, 1851. Published, in part, in Manuscript Releases: From the Files of the Letters and Manuscripts Written by Ellen G. White, 21 vols. Silver Spring, MD: E. G. White Estate, 1981-1993.

, Topsham, ME, to Brother [Joseph] Bates, April 7, 1847. Letter 1, 1847. Center for Adventist Research, James White Library, Andrews University, Berrien Springs, MI. Published as component of James White, ed., A Word to the "Little Flock." Gorham, ME: [by the editor], 1847. Reprinted as Part I of George R. Knight, ed., Earliest Seventh-day Adventist Periodicals, with an introduction by George R. Knight, Adventist Classic Library, ed. George R. Knight. Berrien Springs, MI: Andrews University Press, 2005.

. "A Call to Repentance. Talk by Mrs. E. G. White, Sabbath, April 4, 11 A.M." General Conference Bulletin, April 6, 1903, 88-91.

. "The Character of the Law of God." Signs of the Times, April 15, 1886, 225$226(1-2)$.

. "Christ and the Law." MS 5, 1889. Sermon given at Rome, NY, June 19, 1889. Published in Ellen G. White, Sermons and Talks. Silver Spring, MD: E. G. White Estate, 1990-1994.

. "Christ and the Law; or the Relations of the Jew and Gentile to the Law." Signs of the Times, August 25, 1887, 513-514 (1-2).

. "Christ Represents the Beneficence of the Law." Advent Review and Sabbath Herald, March 9, 1897, 145-146 (1-2). 257.

. "Christian Perfection." Advent Review and Sabbath Herald, April 24, 1900, 
White, Ellen G. Christ's Object Lessons. Washington, DC: Review and Herald, 1941. . "Communications to Elder M. Hull." Advent Review and Sabbath Herald, January 19, 1864, 62-63.

. The Complete Published Ellen G. White Writings. Version 3.0. CD-ROM. Silver Spring, MD: Ellen G. White Estate, 1997. 244).

."The Days of the Son of Man." Signs of the Times, April 17, 1901, 3-4 (243. "Dear Brethren and Sisters." Present Truth, September 1849, 31-32.

, to [Dear Brethren Colcord, Starr, and Hickox], [November 29], 1899. Letter 195, 1899. Published, in part, in Christ Triumphant. Hagerstown, MD: Review and Herald, 1999.

. "Dear Brethren of the General Conference." Letter written from George's Terrace, St. Kilda Road, Melbourne, Australia, 23 December 1892. Daily Bulletin of the General Conference, February 27, 1893, 407-409.

. The Desire of Ages: The Conflict of the Ages Illustrated in the Life of Christ. Mountain View, CA: Pacific Press, 1940.

. Diary entry, October 27, 1889. Published under the title "Battle Creek, Mich., Sunday, October 27, 1889" The Ellen G. White 1888 Materials. Washington, DC: Ellen G. White Estate, 1987.

, to Dr. Burke, December 20, 1889. Letter 15, 1889. Published, in part, in Manuscript Releases: From the Files of the Letters and Manuscripts Written by Ellen G. White, 21 vols. Silver Spring, MD: E. G. White Estate, 1981-1993.

. "Duty of Parents to Their Children." Advent Review and Sabbath Herald, September 19, 1854, 45-46.

. Early Writings of Ellen G. White. Washington, DC: Review and Herald, 1945. , to Edgar Caro, October 2, 1893. Letter 17a, 1893. Published, in part, in Manuscript Releases: From the Files of the Letters and Manuscripts Written by Ellen G. White, 21 vols. Silver Spring, MD: E. G. White Estate, 1981-1993. . Education. Mountain View, CA: Pacific Press, 1952.

. Ellen G. White Writings: Comprehensive Research Edition 2008. CD-ROM. Silver Spring, MD: Ellen G. White Estate, 2009. 
White, Ellen G. "The Exalted Position of the Law of God." Advent Review and Sabbath Herald, September 27, 1881, 209-210 (1-2).

. "Experience and Views." Second Advent Review and Sabbath Herald Extra, July 21, 1851, 1-2.

. "An Extract from a Letter Written to a Distant Female Friend." Advent Review and Sabbath Herald, September 16, 1862, 126.

. "Faith and Works." Signs of the Times, March 30, 1888, 193-194 (1-2).

. "Faith Manifested by Works." Signs of the Times, February 9, 1891, 44 (4).

. "Faithful in Little." Signs of the Times, May 25, 1891, 165 (5).

. "Faithful in That Which Is Least." Youth's Instructor, January 17, 1901, 1.

. "Farewell Words (Concluded): The Peace of Christ." Signs of the Times, November 25, 1897, 4-5 (724-725).

. "The Future." Advent Review and Sabbath Herald, December 31, 1857, 59.

, to the General Conference, c. 1889. Letter 24, 1889. Published, in part, in Manuscript Releases: From the Files of the Letters and Manuscripts Written by Ellen G. White, 21 vols. Silver Spring, MD: E. G. White Estate, 1981-1993.

. "God's Holy Law, the Unchanging Standard." MS 73, 1901. Published in Manuscript Releases: From the Files of the Letters and Manuscripts Written by Ellen G. White, 21 vols. Silver Spring, MD: E. G. White Estate, 1981-1993.

. The Great Controversy between Christ and Satan: The Conflict of the Ages in the Christian Dispensation. Mountain View, CA: Pacific Press, 1950.

. "Have You Oil in Your Vessels with Your Lamps?" Advent Review and Sabbath Herald, September 17, 1895, 593-594 (1-2).

. "He Will Come Again." Youth's Instructor, April 1854, 28-29.

. "His Wonderful Love: Mrs. E. G. White, Sabbath, April 20." General Conference Bulletin, April 23, 1901, 422-426.

. "Humility before Honor." Advent Review and Sabbath Herald, November 8, 1887, 689-690 (1-2). 
White, Ellen G. "The Importance of Exercising Faith.” MS 83, 1891. A talk presented at Harbor Heights, Michigan, July 22, 1891. Published in Ellen G. White, Sermons and Talks. Silver Spring, MD: E. G. White Estate, 1990-1994.

. "Incidents on the Voyage to the North Pacific." Signs of the Times, July 18, $1878,212-213$.

. "Individual Accountability." Advent Review and Sabbath Herald, January 31, $1888,65-66(1-2)$.

. "Individual Effort." Signs of the Times, May 19, 1887, 297-298 (9-10).

. "Is It Well with My Soul?" Morning Talk at South Lancaster, MA, Jan. 13, 1889. Advent Review and Sabbath Herald, March 19, 1889, 177-178 (1-2).

. "Is Not This a Brand Plucked out of the Fire?" [Sermon at Christiania, Norway, November 14, 1885].” Signs of the Times, June 2, 1890, 321-323 (1-3).

. "Issues at the Gen. Conf. of 1889." MS 6, November 4,, 1889. Published in The Ellen G. White 1888 Materials. Washington, DC: E. G. White Estate, 1987.

. "It Is Not for You to Know the Times and the Seasons." Sermon at Lansing, MI, Sept. 5, 1891. Advent Review and Sabbath Herald, March 22, 1892, 177-178 $(1-2)$.

. "The Judgment of the Great Day [Sermon at Orebro, Sweden, June 27, 1886]." Signs of the Times, December 29, 1887, 785-786 (1-2).

. "Lessons from the Fifteenth of Romans." 1906. Sermon preached by E. G. White at the Congregational Church, which was being temporarily used by the Oakland SDA Church, 18th and Market Streets, Oakland, California, on Sabbath afternoon, October 20, 1906. Published in Ellen G. White, Sermons and Talks Silver Spring, MD: E. G. White Estate, 1990-1994.

. Life Sketches of Ellen G. White, Being a Narrative of Her Experience to 1881 as Written by Herself; with a Sketch of Her Subsequent Labors and of Her Last Sickness, Comp. From Original Sources. Mountain View, CA: Pacific Press, 1915.

. “'A Man among Men.” Youth's Instructor, August 16, 1894, 261.

. "The Minister's Relationship to God's Word." MS 13, 1888. A sermon preached in the Seventh-day Adventist Church, Des Moines, IA, December 1, 1888. Published in Ellen G. White, Sermons and Talks. Silver Spring, MD: E. G. White Estate, 1990-1994. 
White, Ellen G. MS 27, 1894. Published, in part, in Ellen G. White, Christ Triumphant. Hagerstown, MD: Review and Herald, 1999.

. MS 38, 1893. Published, in part, in Ellen G. White, In Heavenly Places.

Washington, DC: Review and Herald, 1967.

. MS 43, 1900. Published, in part, under the title "Enoch Kept God's Law" in Ellen G. White, Christ Triumphant. Hagerstown, MD: Review and Herald, 1999.

. MS 125, 1901. Published, in part, in Francis D. Nichol, ed., The Seventh-day Adventist Bible Commentary: The Holy Bible with Exegetical and Expository Comment, 7 vols. Washington, DC: Review and Herald, 1953-1957.

. MS 161, 1897. Published, in part, in Ellen G. White, Selected Messages, 3 vols. Washington, DC: Review and Herald, 1958-1980.

. "The Need of Self-Surrender." MS 148, October 8,, 1899. Published, in part, in Manuscript Releases: From the Files of the Letters and Manuscripts Written by Ellen G. White, 21 vols. Silver Spring, MD: E. G. White Estate, 1981-1993.

. "Nehemiah Separates Israel from Idolaters." Signs of the Times, January 24, $1884,49-50$.

, Hobart, Tasmania, to O. A. Olsen, May 1, 1895. Letter 57, 1895. Published under the title "Warnings Against Worldliness, Rejecting Light, and Unconverted Leaders; an Appeal to Exalt Christ and Proclaim the Message of Righteousness by Faith" in The Ellen G. White 1888 Materials. Washington, DC: E. G. White Estate, 1987.

. "Obedience the Fruit of Union with Christ - No. 2." Advent Review and Sabbath Herald, September 3, 1901, 567-568 (1-2).

. "Opposition to the Sabbath." MS 5, May 18,, 1851. Published under the title "The Sabbath and Other Issues in the Conflict," in Manuscript Releases: From the Files of the Letters and Manuscripts Written by Ellen G. White, 21 vols. Silver Spring, MD: E. G. White Estate, 1981-1993.

. "Our Advocate and Our Adversary." Advent Review and Sabbath Herald, September 22, 1896, 597-598 (1-2).

. Our High Calling: The Morning Watch Texts with Appropriate Selections. Washington, DC: Review and Herald, 1961. 
White, Ellen G, to Philip Wessels, February 3, 1899. Letter 20, 1899. Published, in part, in Manuscript Releases: From the Files of the Letters and Manuscripts Written by Ellen G. White, 21 vols. Silver Spring, MD: E. G. White Estate, 1981-1993.

. "Practical Remarks." Advent Review and Sabbath Herald, April 12, 1870, 130-131.

. "Practical Remarks (Concluded)." Advent Review and Sabbath Herald, April $19,1870,138-139$.

. "Qualifications for the Worker." Advent Review and Sabbath Herald, June 4, $1895,353-354(1-2)$.

. "Redemption - No. 1." Advent Review and Sabbath Herald, February 24, $1874,82-83$.

. "Regarding the Civil War." MS 5, 1862. Published, in part, under the title "The Civil War" in Manuscript Releases: From the Files of the Letters and Manuscripts Written by Ellen G. White, 21 vols. Silver Spring, MD: E. G. White Estate, 1981-1993.

. "Regarding the Late Movement in Indiana: Article Read by Mrs. E. G. White before the Ministers, April 17, 1901." General Conference Bulletin, April 23, 1901, 419-422.

. "The Remnant Church Not Babylon (Continued)." Advent Review and Sabbath Herald, August 29, 1893, 546-547 (2-3).

. "Repentance the Gift of God." Advent Review and Sabbath Herald, April 1, 1890, 193-194 (1-2). 211).

."The Sabbath of the Lord. No. 2." Signs of the Times, April 7, 1898, 2-3 (210. "Sanctification." Advent Review and Sabbath Herald, January 18, 1881, 3334.

. "Sanctification." Signs of the Times, April 13, 1888, 225-226.

. Selected Messages from the Writings of Ellen G. White: Significant and EverTimely Counsels Gathered from Periodical Articles, Manuscript Statements, and Certain Valuable Pamphlets and Tracts Long out of Print. 3 vols. Washington, DC: Review and Herald, 1958-1980.

. "Sin Condemned in the Flesh." Signs of the Times, January 16, 1896, 264-265. 
White, Ellen G. "The Sin of Evilspeaking." MS 168, 1902. Published in Manuscript Releases: From the Files of the Letters and Manuscripts Written by Ellen G. White. 21 vols. Silver Spring, MD: E. G. White Estate, 1981-1993.

. "The Sin of Licentiousness." Advent Review and Sabbath Herald, May 17, 1887, 305-306 (1-2).

. "The Sin of Licentiousness (Concluded)." Advent Review and Sabbath Herald, May 24, 1887, 321-322 (1-2).

. A Sketch of the Christian Experience and Views of Ellen G. White. Saratoga Springs, NY: James White, 1851.

. “A Solemn Lesson." Signs of the Times, August 13, 1894, 627 (3).

. The Spirit of Prophecy. 4 vols. Battle Creek, MI: Steam Press, 1870-1884. Reprint, Washington, DC: Review and Herald, 1969.

. Spiritual Gifts. 4 vols. Battle Creek, MI: Steam Press of the Seventh-day Adventist Pub. Association, 1858-1864. Reprint, Washington, DC: Review and Herald, 1945.

. Spiritual Gifts. Vol. 1, The Great Controversy, between Christ and His Angels, and Satan and His Angels. Battle Creek, MI: James White, 1858. Reprint, as component of Early Writings, Washington, DC: Review and Herald, 1945.

. Spiritual Gifts: My Christian Experience, Views and Labors in Connection with the Rise and Progress of the Third Angel's Message. Battle Creek, MI: James White, 1860. Reprint, Washington, DC: Review and Herald, 1945, as volume 2 of Ellen G. White, Spiritual Gifts: Volumes One and Two.

. Steps to Christ. Mountain View, CA: Pacific Press, 1956.

. The Story of Patriarchs and Prophets: As Illustrated in the Lives of Holy Men of Old. Mountain View, CA: Pacific Press, 1958.

. The Story of Prophets and Kings: As Illustrated in the Captivity and Restoration of Israel. Mountain View, CA: Pacific Press, 1943.

. Supplement to the Christian Experience and Views of Ellen G. White. Rochester, NY: James White, 1854.

. Testimonies for the Church. 9 vols. Mountain View, CA: Pacific Press, 1948. 
White, Ellen G. Testimonies to Ministers and Gospel Workers: Selected from Special

Testimonies to Ministers and Workers. Mountain View, CA: Pacific Press, 1962.

. "Testimony to the Battle Creek Church." MS 16, February 25, 1901.

Published, in part, in Ellen G. White, The Upward Look. Washington, DC:

Review and Herald, 1982.

"To the Brethren and Sisters." Advent Review and Sabbath Herald, June 10, $1852,21$.

. To Those Who Are Receiving the Seal of the Living God. Topsham, [ME], 1849. Reprint, Battle Creek, MI: Belden Reprints, 1938.

. "The True Standard of Righteousness." Advent Review and Sabbath Herald, August 25, 1885, 529-530 (1-2).

. "The True Vine." Advent Review and Sabbath Herald, September 20, 1881, 193-194 (1-2).

. "Two Kinds of Service." Sermon preached Sabbath, February 6, in Oakland, CA. Review and Herald, March 25, 1909, 8-9.

, North Fitzroy, Victoria, Australia, to Uriah Smith, September 19, 1892.

Published under the title "The Message of 1888; An Appeal for Unity; The Need for the Indwelling Christ," in Manuscript Releases: From the Files of the Letters and Manuscripts Written by Ellen G. White, 21 vols. Silver Spring, MD: Ellen G. White Estate, 1981-1993.

. "A Vision God Gave Me at Brother Harris', August 24, 1850.” MS 7, 1850. Extract from pp. 2-3 published under the title "The Open Door," in Manuscript Releases: From the Files of the Letters and Manuscripts Written by Ellen G. White, 21 vols. Silver Spring, MD: E. G. White Estate, 1981-1993.

. "What Shall We Do, That We Might Work the Works of God?" (Concluded)." Sermon at workers' meeting, Grand Rapids, MI. Advent Review and Sabbath Herald, April 21, 1891, 241-242 (1-2).

. "Words to the Young." Youth's Instructor, September 6, 1894, 284-285.

White, James. "The Angels of Rev. xiv - No. 1." Advent Review and Sabbath Herald, August 19, 1851, 12.

. "The Gospel." Advent Review and Sabbath Herald, May 6, 1862, 180.

. "Gospel Union." Advent Review and Sabbath Herald, November 25, 1851, 56. 
White, James. The Law and the Gospel: A Treatise on the Relation Existing between the Two Dispensations. Battle Creek, MI: Seventh-day Adventist Publishing Association, [1870?]. Reprint, London: International Tract Society, [190?].

. Life Incidents: In Connection with the Great Advent Movement as Illustrated by the Three Angels of Revelation XIV. Battle Creek, MI: Steam Press of the Seventh-day Adventists Pub. Association, 1868.

. "The Third Message." Advent Review and Sabbath Herald, November 3, $1859,188$.

. "Western Tour." Advent Review and Sabbath Herald, November 8, 1870, 165.

, ed. A Word to the "Little Flock." Gorham, ME: [by the editor], 1847. Reprint, as Part I of George R. Knight, ed., Earliest Seventh-day Adventist Periodicals, with an introduction by George R. Knight, Adventist Classic Library, ed. George R. Knight. Berrien Springs, MI: Andrews University Press, 2005.

[White, James]. "The Angry Nations." Advent Review and Sabbath Herald, March 7 , $1854,52-53$.

White, James, and Ellen G. White. Life Sketches: Ancestry, Early Life, Christian Experience, and Extensive Labors of Elder James White, and His Wife Mrs. Ellen G. White. Battle Creek, MI: Seventh-day Adventist Pub. Association, 1880.

Wieland, Robert J. "The Atonement in Its Wider Aspect as a Vindication before the Universe of the Character of God." Term paper, Andrews University, 1965. Center for Adventist Research, James White Library, Andrews University, Berrien Springs, MI.

Words of the Pioneers. 2d ed. CD-ROM. Loma Linda, CA: Adventist Pioneer Library, 1995.

Zurcher, J. R. Touched with Our Feelings: A Historical Survey of Adventist Thought on the Human Nature of Christ. Hagerstown, MD: Review and Herald, 1999. 